UNIVERSIDADE DE SÃO PAULO

ESCOLA DE ENFERMAGEM DE RIBEIRÃO PRETO

HELCIMARA AFFONSO DE SOUZA

EDUCAÇÃO EMPREENDEDORA: CONTRIBUIÇÕES PARA A FORMAÇÃO DO PERFIL EMPREENDEDOR DE ALUNOS DA ENFERMAGEM

RIBEIRÃO PRETO

2019 


\section{EDUCAÇÃO EMPREENDEDORA: CONTRIBUIÇÕES PARA A FORMAÇÃO DO PERFIL EMPREENDEDOR DE ALUNOS DA ENFERMAGEM}

Tese apresentada à Escola de Enfermagem de Ribeirão Preto da Universidade de São Paulo, para obtenção do título de Doutor em Ciências, Programa de Pós-Graduação em Enfermagem Psiquiátrica.

Linha de pesquisa: Educação para a Saúde e formação de recursos humanos

Orientador: Sonia Maria Vilela Bueno

Coorientador: Carla Aparecida Arena Ventura

RIBEIRÃO PRETO 
Autorizo a reprodução e divulgação total ou parcial deste trabalho, por qualquer meio convencional ou eletrônico, para fins de estudo e pesquisa, desde que citada a fonte.

Souza, Helcimara Affonso de

EDUCAÇÃO EMPREENDEDORA: CONTRIBUIÇÕES PARA A FORMAÇÃO DO PERFIL EMPREENDEDOR DE ALUNOS DA ENFERMAGEM. Ribeirão Preto, 2019.

265 p. : il. ; $30 \mathrm{~cm}$

Tese de Doutorado, apresentada à Escola de Enfermagem de Ribeirão Preto/USP. Área de concentração: Enfermagem Psiquiátrica.

Orientador: Sonia M. Vilela Bueno

Coorientador:Carla Ap. Arena Ventura

1. Empreendedorismo. 2. Educação empreendedora. 3.Empreendedorismo na saúde. 4.Perfil empreendedor. 5.Enfermagem. 
SOUZA, Helcimara Affonso de

EDUCAÇÃO EMPREENDEDORA: CONTRIBUIÇÕES PARA A FORMAÇÃO DO PERFIL EMPREENDEDOR DE ALUNOS DA ENFERMAGEM

Tese apresentada à Escola de Enfermagem de Ribeirão Preto da Universidade de São Paulo, para obtenção do título de Doutor em Ciências, Programa de Pós-Graduação em Enfermagem Psiquiátrica.

Aprovado em

Presidente

Prof. Dr.

Instituição:

Comissão Julgadora

Prof. Dr.

Instituição:

Prof. Dr.

Instituição:

Prof. Dr.

Instituição: 
Dedicatória

Dedico este trabalho a minha família, aos colegas de profissão e a todos que me ajudaram a alcançar mais essa meta. 


\title{
Agradecimentos
}

\author{
"Ninguém ignora tudo. \\ Ninguém sabe tudo. \\ Todos nós sabemos alguma coisa. \\ Todos nós ignoramos alguma coisa. \\ Por isso aprendemos sempre”. \\ (Paulo Freire)
}

Agradeço a Deus, pelas bençãos, em forma de força, de saúde e de paz.

Agradeço ao meu esposo e parceiro, André, por todo companheirismo e carinho. E aos meus filhos, Mariana e Pedro, minhas alegrias de viver. Sem vocês jamais teria chegado até aqui. Aos meus pais, Marlene e Helcio, pelo carinho e compreensão nos momentos de ausência. Família... base de tudo!!

À Profa. Carla Ventura pelo apoio e acolhida.

À Profa. Sonia Vilela Bueno, a Profa. Soninha, pelo exemplo de pessoa que é!

À Profa. Marta Cristiane, pela amizade e atenção. Gratidão eterna!!

Às minhas amigas de trabalho, pelo carinho e suporte.

A todos que estiveram comigo durante este percurso. 


\section{RESUMO}

SOUZA, H. A. EDUCAÇÃO EMPREENDEDORA: CONTRIBUIÇÕES PARA A FORMAÇÃO DO PERFIL EMPREENDEDOR DE ALUNOS DA ENFERMAGEM. 2019. 265f. Tese (Doutorado) Escola de Enfermagem de Ribeirão Preto, Universidade de São Paulo, Ribeirão Preto, 2019.

O empreendedorismo é um fenômeno socioeconômico que tem sido valorizado em virtude da sua influência no crescimento e desenvolvimento das nações. O sujeito desse fenômeno é o empreendedor, sujeito dotado de múltiplas características que compõem seu perfil e que atua de forma dinâmica, voltada para colher resultados, frutos de seus esforços pessoais. A educação empreendedora é, portanto, destacada como uma das formas mais eficazes de se trabalhar a cultura e formar novos profissionais, sejam eles da área de humanas, exatas ou biológicas, considerando seu perfil inovador, que busca novas formas de agir ou lidar com situações em que identifica possibilidade de melhoria. Assim, este estudo objetivou contribuir para a formação empreendedora de alunos da saúde, buscando descrever as características comportamentais empreendedoras dos alunos ingressantes e concluintes dos três cursos de enfermagem pesquisados, por meio de um instrumento de pesquisa desenvolvido por David McClelland. As análises qualitativas ocorreram por meio de análise de conteúdo, categorização e enunciação, resultantes de processo de leitura flutuante. As análises quantitativas ocorreram por meio de análises descritivas de média, mínima e máxima, desvio padrão e variância, distribuição e dispersão. Conclui-se por meio do presente estudo, que os alunos dos três cursos pesquisados possuem as dez características comportamentais empreendedoras, no entanto, as médias das pontuações ficaram em patamares entre 15 e 20 pontos numa escala de 25 pontos. As pontuações obtidas pelas médias, tanto de ingressantes como de concluintes, apresentaram níveis considerados muito baixo, baixo e mínimo satisfatório. Diante desta pontuação, recomendase buscar articular ações didático-pedagógicas que promovam a autonomia do discente para ações empreendedoras que resultem no seu empoderamento, no sentido de ação autônomas por parte do aluno. Como contribuição acadêmica, os resultados do presente estudo podem abrir caminhos para novas pesquisas relacionadas ao conhecimento empreendedor e experiência prévia, diante de ações que envolvam a educação empreendedora, visto que aponta ligação entre o ensino do empreendedorismo e as habilidades desenvolvidas na educação superior. Como contribuição prática, os resultados revelam possíveis direções para o estímulo do empreendedorismo, tendo em vista o consenso de que os empreendedores não necessariamente nascem empreendedores, mas se desenvolvem ao longo do tempo. Para isso, reforça-se a necessidade de incluir a educação empreendedora como pauta no ensino superior, sugerindo-a como mínima junto aos currículos dos diferentes cursos de graduação, para que seu conteúdo alcance o estudante por meio de inserções teóricas e experiências práticas, preparando-os para os desafios que irão enfrentar na profissão.

Palavras-Chave: Empreendedorismo. Perfil empreendedor. Educação empreendedora.

Empreendedorismo na saúde. Enfermagem. 


\begin{abstract}
SOUZA, H. A ENTREPRENEUR EDUCATION: CONTRIBUTIONS TO THE FORMATION OF THE NURSING STUDENT ENTREPRENEUR PROFILE. 2019. 265f. Thesis (Doctorate) - Ribeirão Preto College of Nursing, University of São Paulo, Ribeirão Preto, 2019.
\end{abstract}

Entrepreneurship is a socioeconomic phenomenon that has been valued because of its influence on the growth and development of nations. The subject of this phenomenon is the entrepreneur, subject with multiple characteristics that make up his profile and that acts dynamically, aimed at reaping results, the result of his personal efforts. Entrepreneurial education is therefore highlighted as one of the most effective ways of working culture and training new professionals, whether human, exact or biological, considering its innovative profile, which seeks new ways of acting or dealing with situations. where it identifies possibility of improvement. Thus, this study aimed to contribute to the entrepreneurial education of health students, seeking to describe the entrepreneurial behavioral characteristics of freshmen and senior students of the three researched nursing courses, through a research instrument developed by David McClelland. Qualitative analyzes occurred through content analysis, categorization and enunciation, resulting from a fluctuating reading process. Quantitative analyzes were performed by descriptive analysis of mean, minimum and maximum, standard deviation and variance, distribution and dispersion. It is concluded from the present study, that the students of the three researched courses have the ten entrepreneurial behavioral characteristics, however, the mean scores were between 15 and 20 points on a 25-point scale. The scores obtained by the averages of both freshmen and graduates presented levels considered very low, low and minimum satisfactory. Given this score, it is recommended to seek to articulate didactic-pedagogical actions that promote student autonomy for entrepreneurial actions that result in their empowerment, in the sense of autonomous action on the part of the student. As an academic contribution, the results of the present study may open the way for new research related to entrepreneurial knowledge and previous experience, in face of actions involving entrepreneurial education, since it points out the connection between entrepreneurship teaching and the skills developed in higher education. As a practical contribution, the results reveal possible directions for encouraging entrepreneurship, in view of the consensus that entrepreneurs are not born, but developed. To this end, it reinforces the need to include entrepreneurial education as an agenda in higher education, suggesting it as a minimum with the curricula of different undergraduate courses, so that its content reaches the student through theoretical insertions and practical experiences, preparing them to the challenges they will face in the profession.

Keywords: Entrepreneurship. Entrepreneurial profile. Entrepreneurial education. Entrepreneurship in health. Nursing. 


\section{RESUMEN}

SOUZA, H. A. EDUCACIÓN EMPRESARIAL: CONTRIBUCIONES A LA FORMACIÓN DEL PERFIL DE EMPRENDIMIENTO DE ESTUDIANTES DE ENFERMERÍA. 2019, 265f. Tesis (Doctorado) Ribeirão Preto College of Nursing, Universidad de São Paulo, Ribeirão Preto, 2019.

El emprendimiento es un fenómeno socioeconómico que ha sido valorado en razón de la influencia en el crecimiento y en el desarrollo de las naciones. El sujeto de ese fenómeno es el emprendedor, sujeto de múltiples características que componen el perfil emprendedor y que actúa dinámicamente, con el objetivo de alcanzar resultados, fruto de sus esfuerzos personales. Por lo tanto, la educación emprendedora se destaca como una de las formas más efectivas de trabajar la cultura y capacitar a nuevos profesionales, ya sean de las humanidades, exactas o biológicas, considerándose el perfil innovador, que busca nuevas formas de actuar o lidiar situaciones en las cuales se identifica la posibilidad de mejoría. De ese modo, este estudio tuvo como objetivo contribuir a la educación emprendedora de los estudiantes de salud, tratando de describir las características del comportamiento emprendedor de los estudiantes de primer año y de los concluyentes de los tres cursos de enfermería investigados, a través de un instrumento de investigación desarrollado por David McClelland. Los análisis cualitativos ocurrieron a través del análisis de contenido, categorización y enunciación, como resultado de un proceso de lectura fluctuante. Los análisis cuantitativos se realizaron a través de análisis descriptivos de media, mínima y máxima, desviación estándar y variancia, distribución y dispersión. Del presente estudio se concluye que los estudiantes de los tres cursos investigados tienen las diez características de comportamiento emprendedor, sin embargo, el promedio de los puntajes estuvo entre 15 y 20 puntos en una escala de 25 puntos. Los puntajes obtenidos por los promedios de estudiantes de primer año y graduados presentaron niveles considerados muy bajos, bajos y mínimos satisfactorios. Dado este puntaje, se recomienda buscar articular acciones didáctico-pedagógicas que promuevan la autonomía del estudiante para las acciones emprendedoras que resulten en el empoderamiento, en el sentido de acciones autónomas por parte del estudiante. Como contribución académica, los resultados del presente estudio pueden abrir el camino para nuevas investigaciones relacionadas al conocimiento emprendedor y a la experiencia previa, frente a las acciones que involucren la educación emprendedora, ya que señala la conexión entre la enseñanza del emprendedorismo y las habilidades desarrolladas en la educación superior. Como contribución práctica, los resultados revelan posibles direcciones para estimular el emprendimiento, en vista del consenso de que los emprendedores no nacen, sino que se desarrollan. Con este fin, refuerza la necesidad de incluir la educación emprendedora como una agenda en la educación superior, sugiriéndola como mínima en los currículos de diferentes cursos de graduación, para que su contenido llegue a los estudiantes a través de inserciones teóricas y experiencias prácticas, preparándolos para los retos que enfrentarán en la profesión.

Palabras clave: Emprendimiento. Perfil emprendedor. Educación emprendedora. Emprendimiento en salud. Enfermería. 


\section{LISTA DE GRÁFICOS}

GRÁFICO 1: FASES HISTÓRICAS DO PAPEL DO TRABALHADOR NO CONTEXTO DE MERCADO ................................53

GRÁFICO 2: EMPREENDEDORISMO COMO MULTI-VISÃO OU MULTIDISCIPLINAR ..................................................8

GRÁFICO 3: EVoluÇão dAS TAXAS TEA, TEE E TTE - NO BRASIL - INSTITUTO GEM (2017) ...............................85

GRÁFICO 4: COMPARAÇÃO DAS TAXAS INTERNACIONAIS - INSTITUTO GEM (2017) ..........................................86

GRÁFICO 5: COMPARAÇÃO DAS RESPOSTAS DOS BRASILEIROS - INSTITUTO GEM BRASIL (2017)..........................86

GRÁFICO 6: SÍNTESE DE TRABALHOS SOBRE ENSINO DO EMPREENDEDORISMO …..........................................91

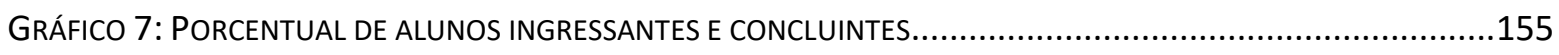

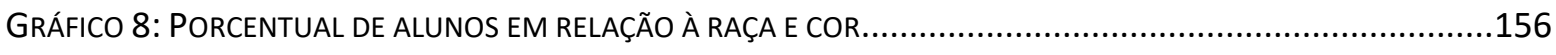

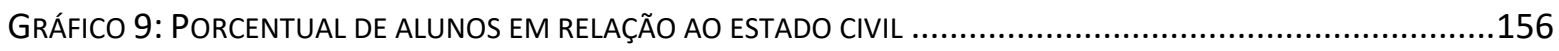

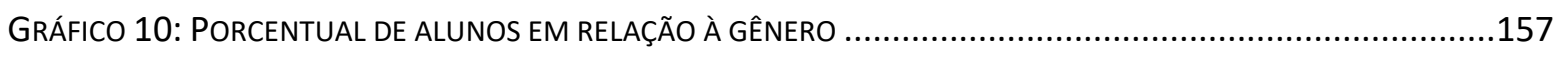

GRÁFICO 11: PoRCENTUAL DE ALUNOS EM RELAÇÃo À GÊNERO ............................................................157

GRÁFICO 12: GRÁFICO DE DISPERSÃO - VARIÁVEIS: NÚMERO DE FILHOS E CCE'S …......................................159

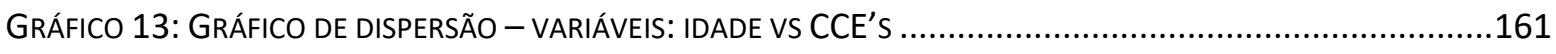

GRÁFICO 14: PORCENTUAL DE ALUNOS EM RELAÇÃo À EMPREENDEDORES NA FAMÍLIA .....................................162

GRÁfico 15: PoRCENTUAL de ALUNOS EM RELAÇÃo À EMPREENDEDORES NA FAMÍLIA - 1ㅇ. E 2o. GRAUS ............163

GRÁFICO 16: PoRCENTUAL DE ALUNOS EM RELAÇÃo CONHECIMENTO DE MERCADO QUE IRIAM ATUAR ................163

GRÁFICO 17: PORCENTUAL DE ALUNOS EM RELAÇÃO CONHECIMENTO DE MERCADO QUE IRIAM ATUAR ................164

GRÁFICO 18: ANÁLISE DESCRITIVA DAS CCE'S POR CURSO - ALUNOS INGRESSANTES …...................................174

GRÁFICO 19: ANÁLISE DESCRITIVA DAS CCE'S POR CURSO - ALUNOS CONCLUINTES .......................................175

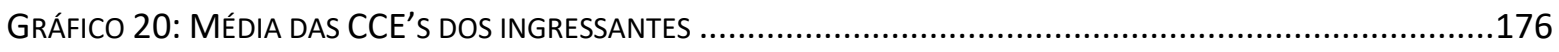

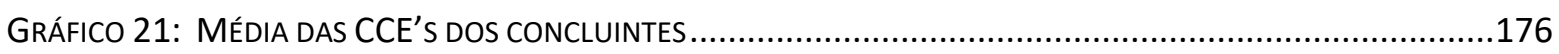

GRÁFICO 22: GRÁFICO COMPARATIVO DAS MÉDIAS DAS CCE'S ENTRE INGRESSANTES E CONCLUINTES ..................178

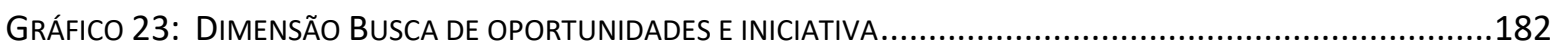

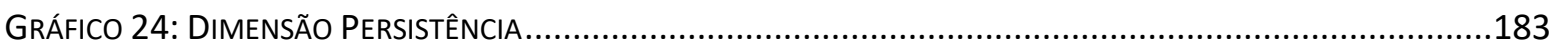

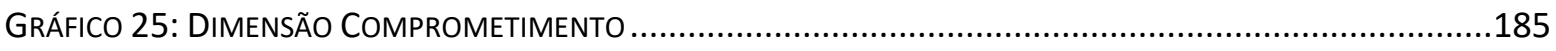

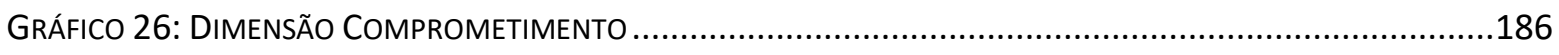

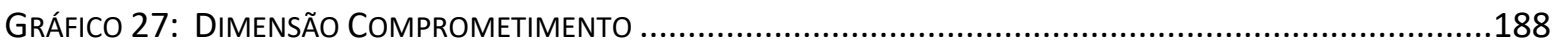

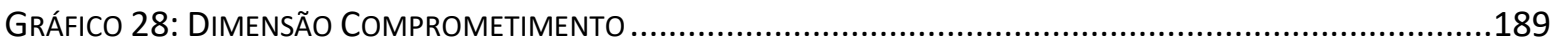

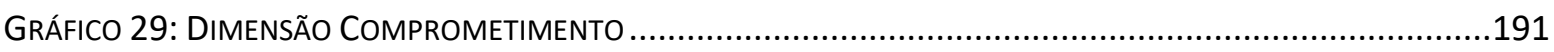


GRÁFICO 30: DIMENSÃO COMPROMETIMENTO

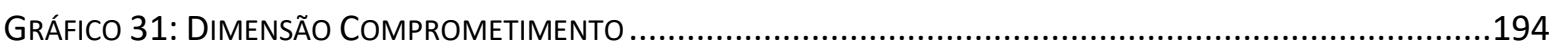

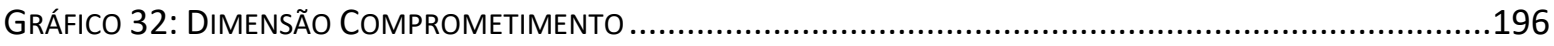

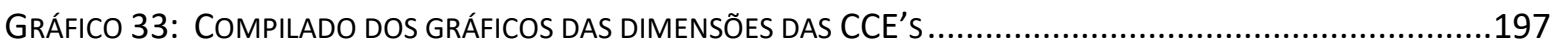

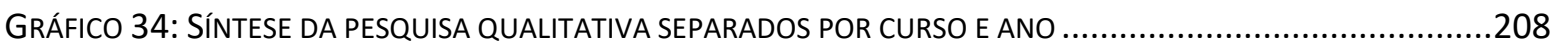

\section{LISTA DE FIGURAS}

Figura 1: PILARES dos ObJetIVOS do ENSINO do EMPREENDEDORISMO

FIgURA 2: PÁGINA DA UNIVERSIDADE, COMO EXEMPLO DAS INFORMAÇÕES DE UM CURSO E CAMPI OFERTADO.....124

FIgURA 3: PÁGINA DA UNIVERSIDADE, COMO EXEMPLO DAS INFORMAÇÕES DE UM CURSO E CAMPI OFERTADO.....124

FIgURA 4: ASPECTOS PROCEDIMENTAIS DA PESQUISA QUALITATIVA....................................................149

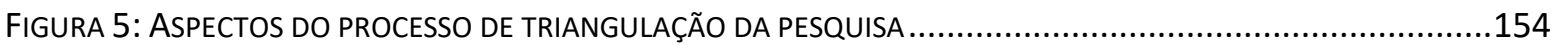

\section{LISTA DE ESQUEMAS}

ILUSTRAÇÃO 1: GRÁFICOS DE DISTRIBUIÇÃO DAS CCE'S GLOBAL COM ANÁLISES .........................................168

ILUSTRAÇÃO 2: GRÁFICO BOXPLOT DAS CCE'S ENTRE INGRESSANTES E CONCLUINTES COM BOXES EXPLICATIVOS....180 ILUSTRAÇÃO 3: NUVEM DE PALAVRAS CONSIDERANDO BLOCOS DE INGRESSANTES E CONCLUINTES 210

\section{LISTA DE QUADROS}

QUADRO 1: QUADRO: ROTEIRO PARA ETAPA DE PESQUISA DOCUMENTAL

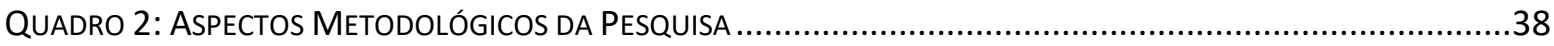

QuAdRo 3: MAPEAMENTO dA PESQUISA EM TERMOS METOdOlóGICOS, A LUZ dOS OBJETIVOS PROPOSTOS..........39

QUADRO 4: OBJETIVOS CURRICULARES DOS CURSOS PESQUISADOS .....................................................41

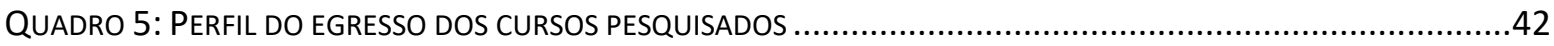

QUADRO 6: MATRIZ CURRICULAR DOS CURSOS PESQUISADOS ...........................................................4

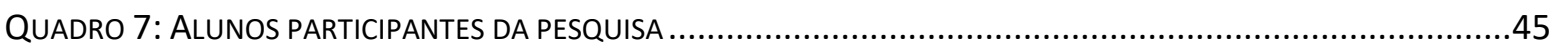


QUADRO 8: SÍNTESE DE DEFINIÇÕES SOBRE O TERMO EMPREENDEDORISMO. .60

QUADRO 9: SÍNTESE DE TERMOS MAIS EVIDENCIADOS NAS DEFINIÇÕES SOBRE EMPREENDEDORISMO ....................61

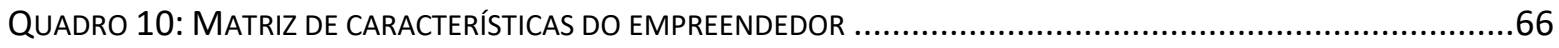

QUADRO 11: ESTUDOS SOBRE O EMPREENDEDORISMO NA DIMENSÃO MULTIDISCIPLINAR .................................77

QUADRO 12: TRABALHOS CIENTÍFICOS SOBRE O ENSINO DO EMPREENDEDORISMO NO ENSINO SUPERIOR ...............93

QUADRO 13: OBJETIVOS DO ENSINO DO EMPREENDEDORISMO NAS IES …..............................................106

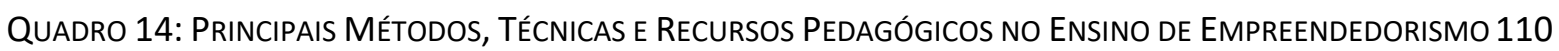

QUADRO 15: CLASSIFICAÇÃO dOS CURSOS OFERECIDOS PELA USP, COM BASE NAS ÁREAS DE CONHECIMENTO.......123

QUADRO 16: CURSOS DA ÁREA DA SAÚDE E SEUS RESPECTIVOS LINKS DE ACESSO ÀS MATRIZES CURRICULARES .......126

QUADRO 17: DETALHAMENTO DAS INFORMAÇÕES DAS DISCIPLINAS IDENTIFICADAS .......................................127

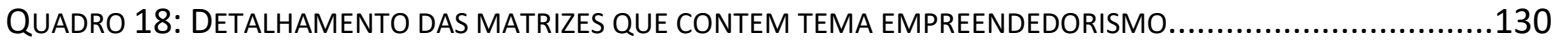

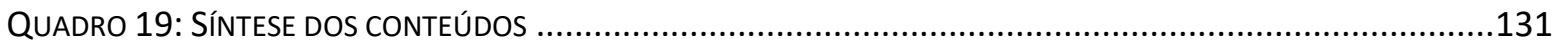

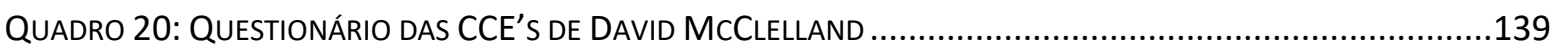

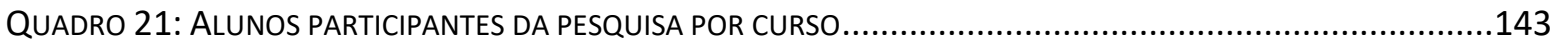

QUADRO 22: ALUNOS PARTICIPANTES DA PESQUISA POR CURSO - UNIVERSO E AMOSTRA..................................144

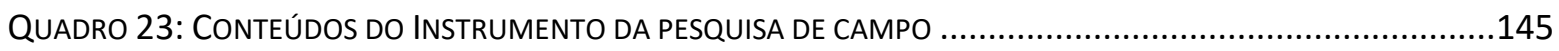

QUADRO 24: QUESTÕES E CARACTERÍSTICAS DO INSTRUMENTO DAS CCE'S...............................................151

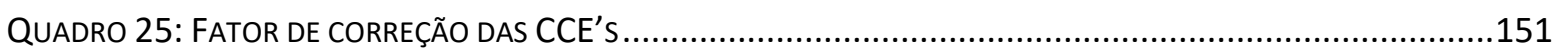

QUADRO 26: QUADRO DE PORCENTUAL DE ALUNOS EM RELAÇÃO AO NÚMERO DE FILHOS ................................157

QUAdRO 27: PorCENTUAL DE ALUNOS EM RELAÇÃo À EMPREENDEDORES NA FAMÍLIA ...................................162

QUADRO 28: PoRCENTUAL DE ALUNOS EM RELAÇÃo À EMPREENDEDORES NA FAMÍLIA - 1‥ E 2ㅇ. GRAUS ............162

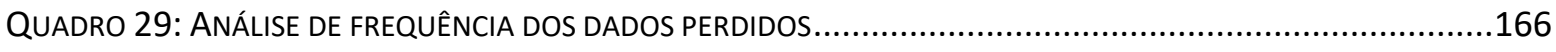

QUADRO 30: DISTRIBUIÇÃO DAS QUESTÕES POR DIMENSÃO $\rightarrow$ * QUESTÕES NEGATIVAS...............................169

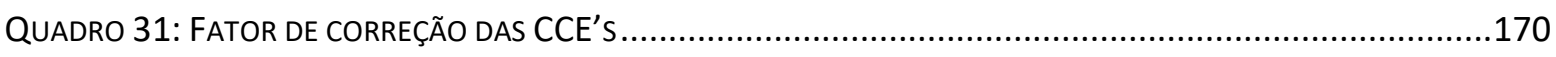

QUADRO 32: FATOR DE CORREÇÃO DAS CCE'S APLICADO A PESQUISA ....................................................170

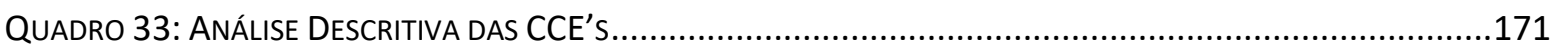

QUADRO 34 : COMPARATIVO DAS MÉDIAS DAS CCE'S ENTRE INGRESSANTES E CONCLUINTES ............................177

QUADRO 35: RESULTADOS DA DIMENSÃO: BUSCA DE OPORTUNIDADES E INICIATIVA ....................................181

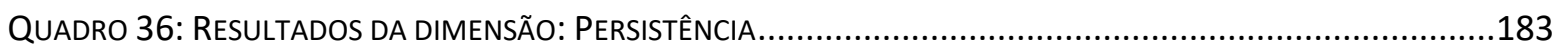

QUADRO 37: RESULTADOS DA DIMENSÃO: COMPROMETIMENTO ..........................................................184

QUADRO 38: RESULTADO DA DIMENSÃO: EXIGÊNCIA DE QUALIDADE E EFICIÊNCIA .........................................186 
QUADRO 39: RESULTADOS DA DIMENSÃO: CORRER RISCOS CALCULADOS

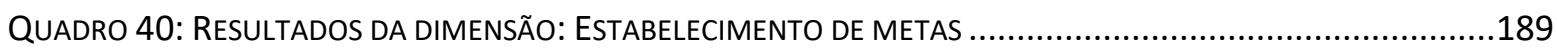

QUADRO 41: RESULTADOS DA DIMENSÃO: BUSCA DE INFORMAÇÕES .......................................................191

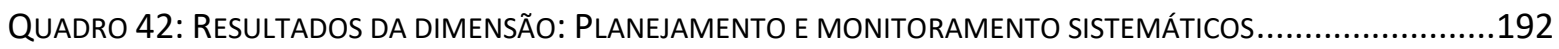

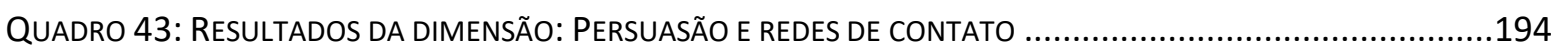

QUADRO 44: RESULTADOS DA DIMENSÃO: INDEPENDÊNCIA E AUTOCONFIANÇA...........................................196

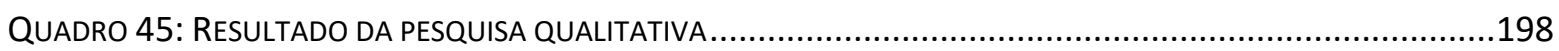

QUADRO 46: RESULTADO DA PESQUISA QUALITATIVA SEPARADOS POR CURSO E ANO....................................199

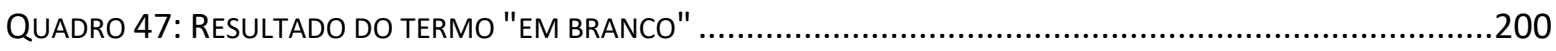

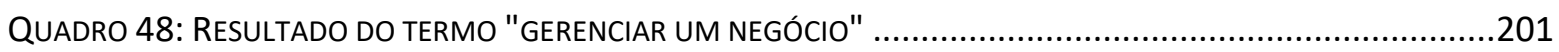

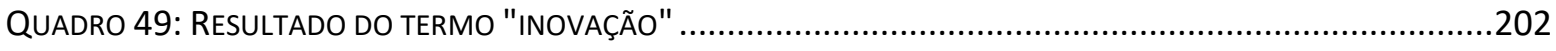

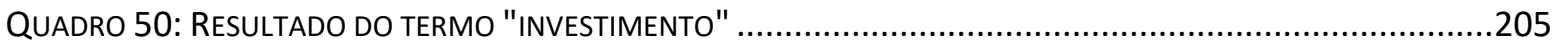

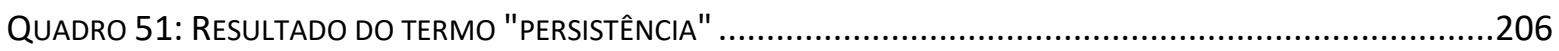

QUADRO 52: RESULTADO DO TERMO "TER SEU PRÓPRIO NEGÓCIO" ..........................................................208

QUADRO 53: RESULTADO DA PESQUISA QUALITATIVA SEPARADOS POR CURSO E ANO.......................................209

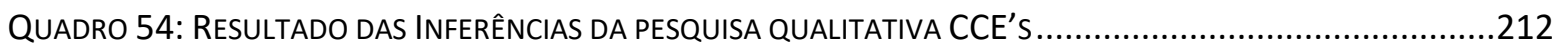

QUADRO 55: ANÁLISE DESCRITIVA DAS CCE'S DE MÉDIA, DESVIO PADRÃO E MEDIANA....................................212

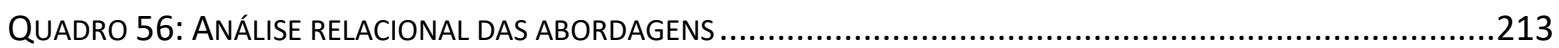

QUADRO 57: DIFERENÇAS ENTRE EDUCAÇÃO CONVENCIONAL E EDUCAÇÃO EMPREENDEDORA............................222 


\section{LISTA DE ABREVIATURAS E SIGLAS}

\begin{tabular}{ll} 
Cape & Centro de Capacitação e Apoio ao Empreendedor \\
CCE's & Características Comportamentais Empreendedoras \\
DCN & diretrizes Curriculares Nacionais \\
EMPRETEC & Seminário de Desenvolvimento Empreendedor do SEBRAE \\
FEA & Faculdade de Economia, Administração e Contabilidade \\
IES & Instituições de Ensino Superior \\
IDH & Índice de Desenvolvimento Humano \\
IMAE & Instrumento de Medida da Atitude Empreendedora \\
GEM & Global Entrepreneurship Monitor \\
GUESS & Global University Entrepreneurial Spirit Students' Survey \\
IBGE & Instituto Brasileiro de Geografia e Estatística \\
LDB & Lei de Diretrizes Básicas \\
LDBEN & Lei de Diretrizes e Bases da Educação Nacional \\
MPEs & Micro e Pequenas Empresas \\
MSI & Management Systems International \\
OCDE & Organização de Cooperação e de Desenvolvimento \\
ONGs & Organizações não governamentais \\
ONU & Organização das Nações Unidas \\
PEC's & Personal Entrepreneurial Characteristics \\
PIB & Produto Interno Bruto \\
PNUD & Programa das Nações Unidas para o desenvolvimento. \\
SEBRAE & Serviço Brasileiro de Apoio às Micro e Pequenas Empresas \\
SIE & Sistema de Informações para o Ensino \\
SOFTEX & Sociedade Brasileira para a Exportação de Software \\
SPSS & Statistical Packagefor the Social Sciences \\
TAT & Thematic Aperception Test \\
TCLE & Termo de Consentimento Livre e Esclarecido \\
TTO & Triple Trust Organization \\
UNCTAD & Conferência das Nações Unidas para o Comércio e Desenvolvimento \\
UNESCO & Organização das Nações Unidas para a Educação a Ciência e Cultura \\
USAID & Agencia para o Desenvolvimento Internacional das Nações Unidas \\
USP & Unive São Paulo \\
\hline STidade &
\end{tabular}




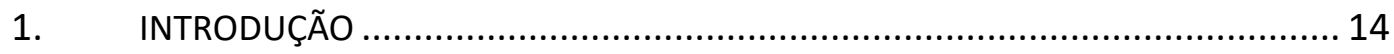

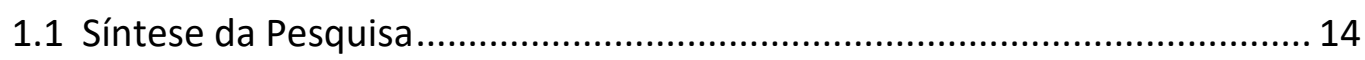

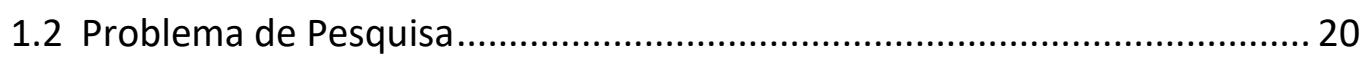

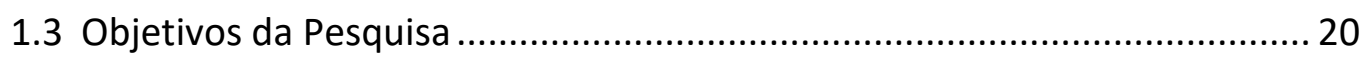

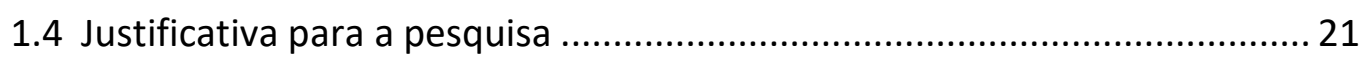

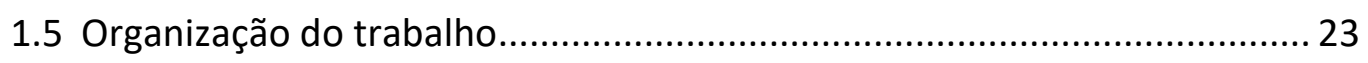

1.6 ASPECTOS METODOLÓGICOS DA PESQUISA ............................................ 23

1.6.1. Participantes da pesquisa e aspectos práticos ................................ 40

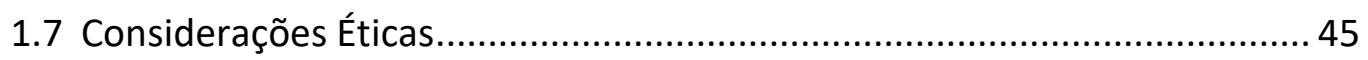

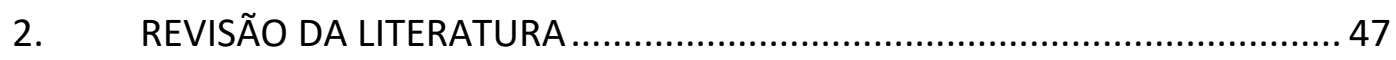

2.1 EMPREENDEDORISMO: Contexto Histórico................................................47

2.2 EMPREENDEDORISMO: Conceitos e Definições .......................................... 54

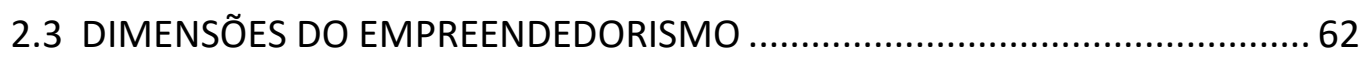

2.4 Considerações acerca dos conceitos sobre Empreendedorismo ................. 80

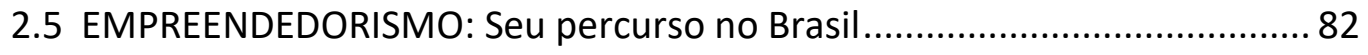

2.6 Considerações acerca do processo evolutivo do empreendedorismo......... 89

2.7 O ENSINO DO EMPREENDEDORISMO ...................................................... 90

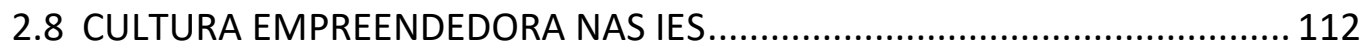

2.9 O Ensino do Empreendedorismo na saúde ............................................ 116

2.10 O Ensino do Empreendedorismo na saúde: Uma Análise Documental.. 120

2.11 Fundamentação Teórica para o uso do Instrumento:

o Perfil Empreendedor desenvolvido por David McClelland ................. 132

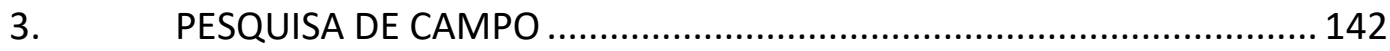

3.1 Participantes - Unidades de análise ........................................................ 142

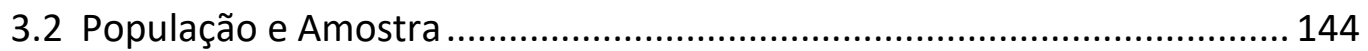

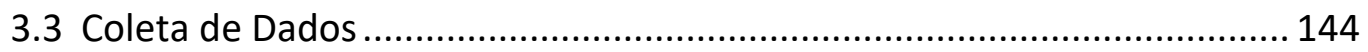

3.4 Análise dos dados da Pesquisa Qualitativa............................................ 146

3.5 Análise dos dados da Pesquisa Quantitativa ........................................ 150

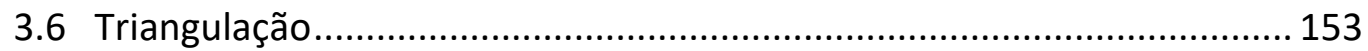

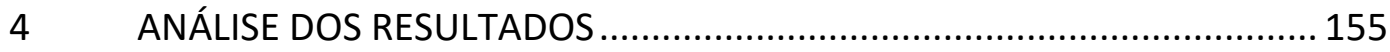

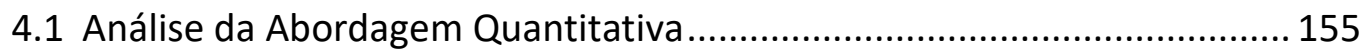

4.1.1 Análise dos Dados perdidos para as questões específicas das CCE’s165 
4.1.2 Metodologia Aplicada na Pesquisa QuantitativaErro! Indicador não definido.

4.1.3 Método de Distribuição dos Dados .................................................. 166

4.1.4 Análise Descritiva das características comportamentais empreendedoras........................................................................ 169

4.1.5 Dimensão: Busca de oportunidades e iniciativa .............................. 181

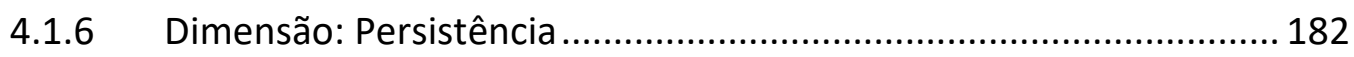

4.1.7 Dimensão: Comprometimento ..................................................... 183

4.1.8 Dimensão: Exigência de qualidade e eficiência ................................ 185

4.1.9 Dimensão: Correr riscos calculados ............................................. 187

4.1.10 Dimensão: Estabelecimento de metas ........................................ 188

4.1.11 Dimensão: Busca de informações................................................. 190

4.1.12 Dimensão: Planejamento e monitoramento sistemáticos ............... 191

4.1.13 Dimensão: Persuasão e redes de contato ....................................... 193

4.1.14 Dimensão: Independência e autoconfiança .................................. 195

4.1.5 Considerações acerca da pesquisa quantitativa .............................. 197

4.2 Análise da Abordagem Qualitativa .................................................. 198

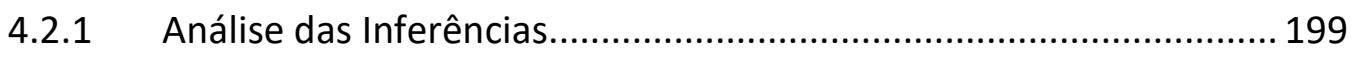

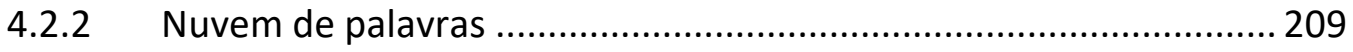

4.2.3 Considerações acerca da Pesquisa Qualitativa................................ 210

4.3 Triangulação dos Dados ................................................................. 211

4.3.1 Triangulação dos Dados com o Ensino do Empreendedorismo ....... 214

4.3.2 Considerações sobre a etapa de triangulação.................................. 219

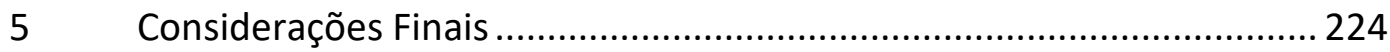

5.1 Limitações e entraves da pesquisa .......................................................... 228

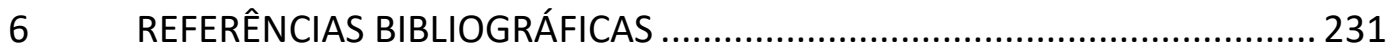

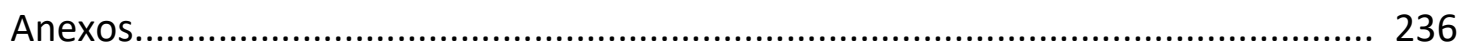




\section{INTRODUÇÃO}

"Sem a curiosidade que me move, que me inquieta, que me insere na busca, não aprendo nem ensino".

Paulo Freire

\subsection{Síntese da Pesquisa}

Historicamente, as descobertas, inovações e avanços tecnológicos estiveram relacionados à inquietude e inconformismo do ser humano. Os avanços das tecnologias, associados à expansão econômica e globalização têm se apresentado como fatores determinantes para um novo perfil profissional que atenda aos desafios atuais. De modo geral, tal cenário favorece a ruptura de comportamento, ou do status quo, levando a busca por pesquisa e inovação, seja de algo inédito ou de uma nova visão, de como oferecer produtos e serviços já existentes (MOTA, 2013). Segundo a autora, o anseio pela produção de novos conhecimentos impulsionou e continua a projetar a humanidade em direção ao seu desenvolvimento.

Por trás dessas buscas, existem pessoas com características especiais, que questionam, arriscam, investigam, pensam diferente e possuem, consequentemente, espírito inovador (DORNELAS, 2013). Assim, as mudanças que vêm ocorrendo aceleradamente nos segmentos profissionais, educacionais, políticos, pessoais, sociais, de maneira global, afetam nossa forma de vida, tanto no nível individual, quanto coletivo. Para Ramalho et al. (2016), a estabilidade é baseada no conceito de empregabilidade e a ação de inovar, de empreender torna-se condição básica para seu sucesso profissional. Ser empreendedor, tornar-se empreendedor, tem sido a alternativa - e, muitas vezes, a exigência - proposta por estes ambientes profissionais. 
Segundo Souza, et.al (2004), as transformações pelas quais a sociedade passou no último século, elevaram o grau de complexidade em que o cenário mundial se desenha, demandando mudanças sobretudo no modo com que lidamos com os desafios do século XXI.

Henrique e Cunha (2006) afirmam que esse cenário emerge, também, em decorrência da necessidade de um novo modelo de gestão, o enxugamento de pessoal na estrutura organizacional atual, das reengenharias nos processos produtivos, reestruturações, privatizações, fusões e ferramentas administrativas, desencadeando novos modelos de negócios e de profissionais que atendam a essas reestruturações. Desse modo, a promoção da atitude empreendedora, com todo seu conjunto de competências e habilidades, assumese como fator de competitividade e desenvolvimento sendo a educação uma via para sua concretização.

A educação empreendedora, porém, gera desafios em sua aplicabilidade, pois depende de uma mudança de concepção da educação para a formação do profissional cidadão, onde a assertividade nas decisões, criticidade e flexibilidade são características comportamentais que precisam ser estimuladas num contexto propício (DORNELAS, 2013). Isso porque, a partir da década de 90 até os dias atuais, o país presencia um cenário caracterizado pela crescente busca do auto emprego, o surgimento de empreendedores involuntários - aqueles que, por falta de emprego e novas oportunidades, procuram abrir algum tipo de negócio para sua sobrevivência financeira e profissional. Segundo Mota (2013), as teorias de gestão modernas, que conceituam as técnicas sobre capacitação de empreendedores, apregoam a seguinte necessidade: a de preparar as pessoas para aprenderem a agir e pensar autonomamente, com criatividade, liderança e visão de futuro, para inovar e ocupar seu espaço no mercado.

David McClelland (1987) argumentou que não existe forma melhor de prover a base para o crescimento econômico, do que incrementar o número de empreendedores na sociedade, por representarem um segmento da população cujo impacto é crucial para o seu desenvolvimento, pois obtêm recursos para produzir bens e serviços, criar empregos e diminuir a dependência dos órgãos públicos.

É indiscutível, portanto, a necessidade de preparar melhor os estudantes antes que eles iniciem sua trajetória profissional, por conta própria, ou mesmo para que atuem como 
empreendedores. Dessa forma, torna-se preponderante disseminar o espírito empreendedor, buscando a elevação do nível de excelência do seu trabalho para permanecerem no mercado (MOTA, 2013). O empreendedor, segundo o autor, é o agente desse processo de construção criativa, é o impulso fundamental que aciona e mantém em marcha a engrenagem dos mercados, constantemente criando novos serviços e produtos, novos métodos de se produzir, novas relações e, implacavelmente, sobrepondo-se aos antigos métodos menos eficientes e mais onerosos.

Para Dornelas (2013) e Muraro e Verruck (2012), uma característica essencial de todo empreendedor é seu potencial de proatividade na busca por conhecimento e a forma com que processa novas informações, diferenciando-se dos demais homens de sua época. Aliás, cada época traz consigo características distintas. Do trabalho escravo ao trabalho assalariado, do emprego ao trabalho autônomo, cada transição representou transformações na forma de produção e, consequentemente, na concepção e construção do trabalhador e de sua subjetividade. É a partir do trabalho que os homens se tornam seres sociais, distinguindo-se dos demais seres.

Para Salim e Silva (2010), todas essas transformações no perfil empreendedor reconhecido pelo valor como promotor de desenvolvimento econômico, pela capacidade de gerar empregos, pela criação de produtos inovadores, pela atuação na busca de soluções para questões sociais e até mesmo pela inclusão em programas governamentais - resultam direta ou indiretamente, no desenvolvimento local e regional. Mas, embora tenhamos na história atribuído o perfil empreendedor às grandes obras, o empreendedorismo tem muito mais realizações em planos mais simples: na construção de casas para moradia, novas formas de prestação de serviços à uma comunidade, ampliação do número de ONG's - Organizações não governamentais, com foco na atenção às populações marginalizadas, ou até mesmo instituições voltadas à melhoria da qualidade de vida de uma região. Para Muraro e Verruck (2012), pequenas ou grandes ações, aplicadas a pequenas ou grandes instituições, fazem parte de um movimento denominado de era do empreendedorismo, e que, segundo Dornelas (2014), se destaca pelo movimento de pessoas que estão transformando a nossa sociedade e nosso modo de vida. 
Esta era do empreendedorismo, inserida no contexto da nova economia ou sociedade do conhecimento, mostra que ideias inovadoras, know how, bom planejamento e, principalmente, equipes competentes e motivadas são ingredientes poderosos que, quando somados, podem gerar oportunidades promissoras em curto espaço de tempo. O contexto atual é propício para o surgimento de um número cada vez maior de profissionais com perfil empreendedor. Ainda segundo Dornelas (2014), são esses profissionais, os responsáveis por eliminar barreiras culturais e sociais, encurtando distâncias, criando novas relações de trabalho e emprego, agregando valor e gerando riqueza para a sociedade.

$\mathrm{O}$ ambiente gerado pelo fomento desta cultura empreendedora produz riqueza e contribui para a melhoria da qualidade de vida das pessoas (ROCHA e BACCHI, 2010; SOUZA, 2015). Para os autores, a cultura empreendedora torna-se estímulo para o empreendedorismo voltado a negócios, que resulta numa significativa presença das micro e pequenas empresas (MPE) no Produto Interno Bruto (PIB). A oferta de empregos que advém desses negócios traz o reconhecimento do relevante papel do empreendedorismo também como agente do desenvolvimento social e econômico da sociedade, atraindo a atenção de várias áreas e profissões.

Devido a essa projeção como força motora do desenvolvimento econômico e social das nações, o empreendedorismo é protagonizado, fundamentalmente, por duas razões distintas: possibilidade de novas oportunidades profissionais e geração de empregos a partir da inovação e criatividade dos profissionais que empreendem (DOLABELA, 2008).

Independente da área, do segmento ou da região, a promoção de estudos que estimulem uma educação empreendedora pode contribuir para seu crescimento. Essa realidade pode ser facilmente percebida em cursos voltados à área de negócios que tradicionalmente trabalham a formação empreendedora de seus alunos. Razão pela qual o termo empreendedorismo esteve relacionado à empresário por algum tempo, como veremos mais adiante. No entanto, áreas como da educação e biológicas, compostas por professores, enfermeiros, médicos, dentistas, etc., podem fazer uso desta importante ferramenta, promovendo uma educação voltada a empreender, para a busca da inovação e novos métodos de trabalho (LOPES, 2010). 
A enfermagem, área da qual este estudo se projeta, presenciou nas últimas décadas, substanciais mudanças em seu currículo buscando atender às exigências impostas pelos novos formatos de trabalho e novos arranjos dos serviços de saúde (SOUZA et.al, 2006). O "cuidar" sempre protagonizou as ações do enfermeiro, porém, este cuidar também passou por fases de construção e reconstrução, ganhando novas abordagens para atender a uma exigência do contexto ao qual se adequava. Ainda segundo os autores, esta preocupação com o "cuidar" e todos seus preceitos inerentes (saúde, ajuda e bem-estar) esteve presente mesmo antes de fazer parte do corpo das teorias de estudo e sua prática profissional que buscavam originalmente desenvolver competências técnicas e procedimentais. Em meados do século passado, a enfermagem passa a buscar por princípios científicos em outros saberes fazendo uso do modelo biomédico. A partir de 1960, dá início à construção de um corpo de conhecimento próprio, contribuindo para um melhor desenvolvimento no processo de cuidar (ORTEGA et.al, 2015).

A partir da década de 1970, movimentos políticos e sociais possibilitaram um repensar no modelo de trabalho do processo saúde-doença, levando a enfermagem rever vários conceitos sobre a postura da prática profissional, o que culminou em mudanças curriculares, contribuindo para um processo de transformação na profissão. A implantação do SUS, na década de 1990 suscitou novas reflexões sobre formas de abordar o processo saúde-doença, dentro de um contexto sócio-histórico-político-econômico que promoveu amplos debates por parte dos profissionais de saúde, governo e sociedade civil (SOUZA et.al, 2006). Segundo os autores, a construção de uma nova estrutura curricular contou com fato inédito: a população pôde participar desse processo, por meio de propostas e avaliação do contexto da saúde pública no país, contribuindo para uma nova forma de se ver a assistência à saúde e aproximando os profissionais de saúde e a comunidade assistida. Outros atores também se envolveram como professores, alunos e profissionais da assistência social.

Hoje, os Projetos Políticos Pedagógicos (PPP) da enfermagem, baseados em novas diretrizes curriculares, adotadas em consonância com a Lei de Diretrizes e Bases da Educação Nacional (LDB) no 9394/96, proporcionam mudanças no processo de formação do enfermeiro, de modo que a ênfase, deixa de estar centrada no modelo biomédico, caracterizado pelo estudo da doença, aprendizagem e reprodução de técnicas e tarefas, e passa a estar centrada em um modelo holístico, humanizado e contextualizado, formando profissionais críticos, criativos e éticos para atuar na prática profissional (SOUZA et.al, 2006, s/p). 
A perspectiva das diretrizes curriculares para a formação do enfermeiro é formar profissionais com compreensão científica, técnica, política e ética, capazes de intervir no processo saúde-doença do ser humano, numa perspectiva crítico-transformadora voltada para o cuidar, o educar, gerenciar e pesquisar, caracterizando interesses técnicos, práticos e emancipatórios (SOUZA et.al, 2006). Trata-se, desta forma, de ampliar a atuação do profissional, pautado na ação curativista, para dar conta desta complexidade do processo saúde-doença e reformular as práticas assistenciais e coletiva da comunidade de forma humanizada, responsável e competente (PADOVANI e CORRÊA, 2017).

Nessa perspectiva, a pesquisa documental deste estudo que precedeu o trabalho de campo analisou as matrizes curriculares dos cursos da área de biológicas buscando entender o contexto do ensino do empreendedorismo na área da saúde, tendo em vista o empreendedorismo ser uma área de estudo que promove o desenvolvimento de características profissionais que vão ao encontro das exigências da profissão, descritas por Souza et.al. (2006).

Além das matrizes curriculares, também foram analisados os planos de ensino das disciplinas desses cursos, o conteúdo programático que poderiam trazer temas voltados ao empreendedorismo. Além das documentações dos cursos, também foram analisadas as diretrizes curriculares nacionais, as DCN's, documentação legal expedida pelo MEC que regulamenta os cursos superiores no país. Esta pesquisa documental, que será apresentada no capítulo sobre educação empreendedora nas universidades, demonstrou que, apesar das diretrizes curriculares dos cursos da área da saúde trazerem conteúdo voltado à formação empreendedora, não foi identificada disciplina sobre empreendedorismo nas matrizes curriculares eletivas dos cursos, razão pela qual a presente pesquisa foi projetada.

Para a fase da pesquisa de campo, foram selecionados três cursos de graduação em enfermagem sendo um público e dois privados, com alunos ingressantes e concluintes, buscando analisar com base nas características comportamentais empreendedoras que trata a literatura, o perfil empreendedor desses alunos e possíveis mudanças em sua formação, comparando os resultados entre calouros e formandos. As discussões teóricas sobre o tema mostra que a ausência de disciplinas voltadas a formação empreendedora pode gerar dificuldade aos seus egressos, para desempenharem atitudes empreendedoras em suas 
profissões, seja num negócio próprio ou mesmo empreendendo dentro do escopo de trabalho no qual já atua.

O ensino do empreendedorismo, portanto, vem com este objetivo, o de ensinar aos alunos o desenvolvimento dessas habilidades, e que juntas são capazes de promover o perfil autônomo dos alunos, preparando-os para enfrentar os desafios do mercado, buscar novas formas de oferecer seus serviços, analisar quem é o seu consumidor, suas necessidades e expectativas, o que o mercado oferece e o que se pode fazer para se diferenciar e se destacar no segmento (LOPES, 2010).

\subsection{Problema de Pesquisa}

Diante do exposto, dos estudos prévios sobre conteúdos voltados ao ensino do empreendedorismo em cursos da área da saúde, especificamente na enfermagem, e a ausência desse conteúdo nas matrizes curriculares e nos cursos pesquisados, tem-se o seguinte problema de pesquisa:

- Apesar da inexistência de disciplinas voltadas ao ensino do empreendedorismo nos cursos pesquisados, é possível afirmar que o aluno terá adquirido no transcorrer do curso, as habilidades empreendedoras, elencadas no perfil empreendedor, segundo as características comportamentais empreendedoras de David McClelland (autoconfiança, liderança e trabalho em equipe; assumir riscos calculados; dedicação e comprometimento;

planejamento; persistência; busca de oportunidades; inovação; delegação de autoridade e iniciativa)?

\subsection{Objetivos da Pesquisa}

Tem-se como objetivo geral:

- Descrever características comportamentais empreendedoras em alunos de três cursos graduação em enfermagem. 
Tem-se como objetivos específicos:

- Analisar comparações do perfil empreendedor de alunos ingressantes e concluintes dos cursos pesquisados, buscando identificar discrepâncias e/ou similaridades;

- Analisar comparações do perfil empreendedor dos alunos entre os três cursos, buscando identificar parâmetros que expliquem possíveis variações;

- Compreender o entendimento dos alunos sobre o tema empreendedorismo;

- Propor ações pedagógicas que possibilitem o processo de ensino das habilidades empreendedoras.

\subsection{Justificativa para a pesquisa}

O tema empreendedorismo vem sendo amplamente estudado nas mais diversas áreas por ser considerado um diferencial fundamental para o êxito na realização das atividades profissionais. Não somente pelo seu aspecto de gestão - característica predominante no empreendedor - mas sobretudo por questões que envolvem o comportamento empreendedor como a busca por oportunidades de trabalho, comprometimento, persistência, inovação, assumir riscos calculados, estar atento a tudo que acontece dentro do seu contexto profissional, ou seja, a busca constante por atualização. Tais características não podem ser desenvolvidas apenas em cursos de graduação em negócios. Áreas como saúde, da educação e engenharias, também precisam ter em seu portfólio acadêmico, conteúdos voltados ao desenvolvimento de habilidades empreendedoras em seus alunos. É mais comum vermos profissionais da saúde, por exemplo, partindo para a abertura de um novo empreendimento, que alunos egressos de administração, que de modo geral, se envolvem com atividades na esfera gerencial de empresas, ocupando cargos de direção, gerência e não empreendendo num negócio próprio.

Diante disso, o ensino do empreendedorismo, também nessas áreas, pode favorecer o desenvolvimento do perfil que se deseja para o sucesso ao empreender, seja em um novo negócio, ou como empreendedor organizacional, o chamado intra-empreendedor, que desenvolve ações empreendedoras em seu espaço de trabalho, inovando no atendimento, 
melhorando processos de trabalho, compartilhando informações, promovendo e estimulando o protagonismo profissional. Ou mesmo como empreendedor em projetos pessoais tendo em vista um projeto de vida demandar as mesmas habilidades.

Sendo assim, as universidades passam a ter um papel fundamental no desenvolvimento deste perfil. $O$ ensino do empreendedorismo se faz presente neste processo ao desenvolver uma visão que instigue a busca pela inovação (CUNHA et.al, 2009).

Nessa linha de raciocínio, Dolabela (2009) sugere que o ensino do empreendedorismo seja trabalhado muito antes da faculdade. Para ele, o ensino do empreendedorismo deveria iniciar no ensino fundamental, estimulando o pensamento empreendedor, promovendo atividades que despertem a criatividade, inovação e busca por mudanças na forma de fazer e ver as coisas. Segundo o autor, o aluno não pode ser direcionado para ser um empreendedor com visão apenas em negócio, e sim, de empreender para a vida tendo em vista que nossos projetos e objetivos pessoais podem e devem fazer uso de ferramentas empreendedoras, como persistência, foco, comprometimento, planejamento, estabelecimento de metas, etc. São habilidades inerentes ao ato de empreender e também inerentes a qualquer projeto pessoal.

Ainda para Dolabela (2009), as instituições que se projetam para o ensino do empreendedorismo, na sua grande maioria, o fazem voltados para uma preparação de perfil de empregados, ou seja, dependentes de um vínculo de trabalho, e não de perfil voltado para a autonomia do profissional. Com isso, estimular o empreendedorismo para um contexto empreendedor, autônomo e independente, requer um enfrentamento de resistências neste processo de mudanças, causando impactos para a instituição, docentes e discentes, o que demonstra o quão desafiador é a educação empreendedora.

A educação empreendedora pode aumentar a qualidade na formação de estudantes inovadores e proativos, desenvolvendo expertises focadas no cuidar, cerne da profissão do enfermeiro. Diante disso, tem-se a educação empreendedora como tema atual e relevante para o embasamento do presente estudo. 


\subsection{Organização do trabalho}

Este trabalho resulta numa tese e está organizado em cinco capítulos. O capítulo um, denominado Introdução traz, como já visto, uma contextualização do tema e de sua importância para o estudo que se propõe realizar, além da apresentação do tema estudado, os fatores e situações que estão interligados à educação empreendedora e ainda discorre sobre o problema de pesquisa, os objetivos geral e específicos, o escopo da pesquisa sob o planejamento do percurso metodológico adotado, descrevendo o método e a natureza da pesquisa, seleção dos participantes e delimitação do estudo. Traz também as técnicas e instrumentos adotados na coleta de dados e a forma de tratamento e análise destes dados.

O capítulo dois apresenta revisão de literatura sobre o tema empreendedorismo e seus desdobramentos sob o enfoque econômico, comportamental, motivacional, social e tecnológico, além de uma reflexão sobre educação empreendedora e o ensino do empreendedorismo nas instituições de ensino superior, com especial ênfase na área da saúde. O capítulo três descreve a pesquisa de campo e os resultados obtidos na aplicação da pesquisa, após os devidos tratamentos estatísticos quantitativos e qualitativos.

O quarto capítulo traz a discussão dos resultados e o quinto capítulo traz as considerações finais, apresentando também as limitações e entraves da pesquisa, buscando auxiliar futuros pesquisadores nesta mesma temática e instrumental metodológico.

\subsection{Aspectos metodológicos da pesquisa}

"Os que se encantam com a prática sem a ciência são como os timoneiros que entram no navio sem timão nem bússola, nunca tendo certeza do seu destino". Leonardo da Vinci

Assim como toda pesquisa, a busca por respostas aos questionamentos propostos, nos faz passar inevitavelmente por uma reflexão de como chegaremos a elas e de que forma iremos buscá-las. A metodologia da pesquisa científica se ocupa dos processos de construção de conhecimento rigoroso, válido e confiável. A forma pela qual se chega a uma conclusão a respeito do fenômeno investigado é, nesta área, no mínimo tão importante quanto o 
conhecimento em si, e os métodos usados para gerá-lo precisam ser definidos, compreendidos, discutidos e aprimorados para que se possa aplicá-lo a uma realidade empírica (ZAPPELLINI e FEUERSCHÜTTE, 2015).

É na pesquisa científica que reside diferentes métodos, posto que a realidade se apresenta com fenômenos distintos, para os quais se necessita de abordagens metodológicas e técnicas articuladas às características dos objetos de estudo, na perspectiva de conhecê-los e compreendê-los. O pesquisador diante disso, necessita assumir uma visão aberta a todas as manifestações, sem se deixar seduzir pelas suas próprias convicções ou baseadas em conhecimento empírico de um tema. Este formato de pensar e agir de forma pragmática exige uma linearidade no agir, consciente da necessidade de se ter um norte, chamado percurso metodológico (SAMPIERI, et.al, 2013).

Um método, nesse percurso metodológico, compreende um roteiro para a realização de uma pesquisa, que busca resultados novos ou de valor agregado, obtidos a partir de procedimentos reconhecidos como científicos pela comunidade, como um portfólio de práticas que serão úteis e que levarão o pesquisador aos resultados esperados e reconhecimento de seus pares (CERVO E BERVIAN, 2002). Para os autores, tal percurso metodológico deve servir de guia, de instrumento, sendo, portanto, entendido como um meio e não como um fim. Para Richardson (2011) utilizar um método de pesquisa é sistematizar o processo científico na busca de respostas às dúvidas quanto a um problema sobre um fato, um objeto, um fenômeno. É a forma pela qual passa toda descoberta da humanidade. Já a pesquisa, segundo Gil (2002), é definida como um procedimento sistemático e racional e objetiva-se o auxílio na busca de respostas às perguntas ou aos problemas propostos. Ainda para o autor, a pesquisa é utilizada quando as informações não são suficientes para responderem aos problemas ou então quando a informação necessita de uma ordenação para facilitar seu relacionamento com o problema. Para tanto, a tarefa de pesquisa necessita de uma padronização a fim de ordenar as ideias.

A pesquisa de cunho científico, portanto, requer todo este rigor metodológico, não apenas nas questões objetivas do processo metodológico em si, mas também na seleção de estratégias, ferramentas e teorias que confiram o crédito, a confiabilidade e a exequibilidade do processo de pesquisa. É necessário, portanto, não apenas mapear a estrutura do processo 
metodológico, mas também, tão importante quanto, identificar e trazer de forma coerente, as teorias, filosofias, escolas que servirão de alicerce ao que a pesquisa requer desenvolver.

Para Gil (2002), este planejamento tem uma função ampla, envolvendo do desenho (diagramação, design), a previsão de análise e a interpretação dos dados coletados, considerando também, outros aspectos como o ambiente em que os dados são coletados e as formas de controle das variáveis envolvidas.

A pesquisa de cunho científico, portanto, requer todo o rigor metodológico que se possa trabalhar, não apenas nas questões objetivas do processo metodológico, mas também na seleção de estratégias, ferramentas e teorias que confiram o crédito, a confiabilidade e a exequibilidade do processo de pesquisa. É necessário, portanto, não apenas mapear a estrutura do processo metodológico, mas também, tão importante quanto, identificar e trazer de forma coerente, as teorias, filosofias, escolas que servirão de alicerce ao que a pesquisa requer desenvolver.

Quanto a Abordagem, este estudo configura-se como pesquisa quanti-quali, tendo em vista tanto o caráter mensurativo dos dados coletados como também pelo caráter social e comportamental dos sujeitos na forma de tratar as questões que envolvem a problemática da pesquisa, objetivando analisar o nível de conhecimento dos alunos dos cursos pesquisados.

Traçar o tipo de abordagem da pesquisa é escolher o caminho a ser trilhado na construção do conhecimento, considerado o primeiro passo na criação do escopo de um processo investigativo. A partir daí, seleciona-se o método mais apropriado ao tipo de estudo que se deseja realizar, com base na natureza do problema (YIN, 2015). O método qualitativo difere do método quantitativo por não empregar um instrumental estatístico como base do processo de análise. Já a abordagem quanti sim, pois objetiva numerar ou medir unidades ou categorias homogêneas. Outros autores ainda não distinguem literalmente um método do outro por afirmar que toda pesquisa quanti possui uma análise subjetiva e por consequência, uma interpretação voltada aos moldes da pesquisa qualitativa (MAXWELL, 1996).

Os estudos de metodologia quanti-quali podem descrever a complexidade de determinado problema por meio de levantamentos estatísticos e também analisar a 
interação de certas variáveis, compreender e classificar processos dinâmicos vividos por grupos sociais, contribuir no processo de mudança de determinado grupo e possibilitar, em maior nível de profundidade, o entendimento das particularidades do comportamento dos indivíduos (RICHARDSON, 2011).

A utilização das abordagens quanti-quali nas pesquisas contribui para a ampliação do conhecimento sobre os resultados obtidos pois permite uma triangulação dos dados que, segundo Triviños (1987), favorece um aprofundamento sobre o tema investigado e faça um cruzamento de suas conclusões, de modo a ter maior confiança nos resultados. A combinação dos múltiplos instrumentos de coleta de dados possibilita a triangulação dos dados, favorecendo a complementaridade e garantindo maior profundidade ao estudo. Para Coutinho (2011), a triangulação de dados consiste em combinar dois ou mais elementos, fontes de dados, abordagens teóricas, numa mesma pesquisa para que se possa obter como resultado final um retrato mais fidedigno da realidade ou uma compreensão mais profunda do fenômeno a se analisar.

Ainda para o autor, utiliza-se a abordagem quantitativa em estudos com grandes aglomerados de dados, partindo de um contexto a ser descoberto e estruturada, de modo geral, a partir de um fenômeno social. Trabalha com amostras mais amplas, fornecendo dados mais precisos em relação ao problema estudado. Esta quantificação, por meio de análises estatísticas, resulta em respostas mais confiáveis e validadas pelos métodos aplicados (COUTINHO, 2011).

Para Ramos (2013), o uso de métodos quantitativos para análise de uma realidade social tem o propósito de descrever ou comparar características de grupos sociais, realidades, contextos ou instituições, além de promover condições de se estabelecer relações causais. A pesquisa quantitativa estabelece uma metodologia predefinida ao respondente, reduzindo a heterogeneidade da coleta de dados, inferindo maior credibilidade aos resultados, o que possibilita medir as variáveis do estudo buscando averiguar sua influência sobre outras variáveis.

Já a pesquisa com abordagem qualitativa considera cinco características sendo: estudar o significado da vida real dos indivíduos; representar opiniões e perspectivas dos indivíduos de um estudo; abranger as condições contextuais em que os indivíduos vivem; 
contribuir com revelações sobre os conceitos existentes ou emergentes que podem ajudar a explicar o comportamento humano; e esforça-se por usar múltiplas fontes de evidência em vez de se basear em uma única fonte (MAXWELL, 1996). Nesse sentido, nas pesquisas qualitativas, preferencialmente, os sujeitos de pesquisa devem ser indivíduos ou grupos que estejam envolvidos em experiências semelhantes, ou seja, guardar similaridade quanto ao foco da pesquisa (YIN, 2015). Para Richardson (2011), a pesquisa qualitativa é definida como sendo a busca por uma compreensão detalhada dos significados e características situacionais dos fenômenos.

O enfoque qualitativo, para Minayo (2012), é coerente quando se busca compreender um determinado nível de realidade abstrata com diferentes significados, motivações, crenças, valores e percepções. Sendo o sujeito o autor a autora afirma que na pesquisa qualitativa o primeiro a falar de si é o objeto pesquisado. Trata-se de uma técnica considerada por muitos estudiosos como sendo um tanto quanto subjetiva, pela forma com que os dados são analisados, que leva em conta crenças, ideias e proposições do pesquisador, o que pode influenciar os resultados. Segundo o autor, uma pesquisa se dá em meio a um universo de signos, permeados por aspectos ideológicos ligados à subjetividade nas interpretações do pesquisador. Assim, "a neutralidade de uma investigação científica é um mito e que, portanto, não existe" (MINAYO, 2012, p. 34). Nessa perspectiva, Silva (2015, p. 27) cita que:

... os pesquisadores devem ter presente que o ato de investigar exige 'lidar' com a realidade a partir de pensamentos formados por conceitos e teorias explicitados na literatura, e que se originam em determinados contextos históricos caracterizados por questões sociais, ideológicas, políticas, econômicas, bem como de perspectivas teóricas influenciadas por tais contextos.

Quanto à estratégia de pesquisa, este estudo configura-se como pesquisa descritiva e exploratória. A pesquisa exploratória objetiva proporcionar maior familiaridade com o problema, visando torná-lo mais claro ou constituir hipóteses e/ou explorar problemas pouco conhecidos ou pesquisados. A pesquisa exploratória traz descrições da situação e das relações existentes entre os seus elementos. Seu planejamento deve ser flexível para possibilitar a consideração dos mais diversos aspectos de um problema ou de uma situação. Para Sampieri, et.al (2013), os estudos exploratórios são realizados quando o objetivo é examinar um tema pouco estudado, sobre o qual se tem muitas dúvidas ou que ainda não 
foi abordado antes. Os estudos exploratórios visam investigar objetos de estudo que apresentam carência de conhecimento, e abordam temas pouco estudados na literatura, o que vem de encontro com o presente estudo, considerado pela pesquisadora diante do objetivo estipulado, tema pouco estudado em cursos diferentes dos de negócios.

A pesquisa descritiva apresenta como objetivo identificar as características de determinada população ou fenômeno, ou então o estabelecimento de relações entre as variáveis (GIL, 2002). Classifica-se ainda como quantitativa, pois utiliza a quantificação tanto na coleta de informações, quanto no seu tratamento delas por meio de técnicas estatísticas (RICHARDSON, 2011).

Os métodos utilizados para as etapas de coleta de dados foram pesquisa bibliográfica, pesquisa de campo e pesquisa documental. O método de coleta de dados, para Gil (2002), é um dos elementos mais importante para o planejamento estratégico de uma pesquisa por se tratar da etapa de busca das evidências de uma pesquisa. É o contato com a realidade do campo de pesquisa e por isso requer uma conduta ética e comprometida com esta ação prática. Para o autor, pode- se utilizar de mais de um procedimento em razão da adequabilidade que a pesquisa requer e de suas características não se enquadrarem num modelo único ou num único método. O presente estudo possui esta característica, pois trabalha com quatro modelos de procedimentos técnicos: pesquisa bibliográfica, análise documental e pesquisa de campo.

- Pesquisa bibliográfica: sobre empreendedorismo, empreendedorismo na área da saúde, perfil empreendedor; educação em saúde, metodologias e práticas do ensino do empreendedorismo, proposta de construção de curso na modalidade a distância; educação a distância na área da saúde e ferramentas pedagógicas online;

- Pesquisa de campo: a pesquisa de campo procede de uma observação de fatos e fenômenos exatamente fiel aos fatos ocorridos, sucedidos de uma coleta de dados referentes aos fatos e por fim, à análise e interpretação desses dados, com base numa fundamentação teórica que o valide, objetivando compreender e explicar um determinado fenômeno. A pesquisa de campo neste projeto baseia-se numa pesquisa com alunos do primeiro e do último ano dos cursos de graduação em Enfermagem, bacharel e licenciatura, objetivando identificar o perfil empreendedor desses alunos, com base no que a literatura 
denomina de características do comportamento empreendedor de McClelland. Também buscou-se compreender por meio de pergunta aberta, o que esses alunos entendem pelo tema empreendedorismo (MARCONI e LAKATOS, 2004).

- Pesquisa documental: a pesquisa documental é aquela realizada a partir de documentos contemporâneos ou retrospectivos, advindos de fontes primárias, considerados cientificamente autênticos e importantes para a trajetória de uma pesquisa de cunho científico e suas bases podem ser extraídas desde projetos de lei, atas, gráficos estatísticos, fotografias, pintura, artes, ofícios, inventários, entrevistas e é considerada importante em pesquisas qualitativa, seja complementando informações obtidas por outras técnicas, seja validando proposições do tema ou problema levantado.

Quanto aos instrumentos de coleta de dados, Richardson (2011) diz existirem diversos instrumentos que podem ser utilizados para obter informações sobre determinado problema ou situação, sendo uma das etapas do processo metodológico mais importante para se obter os dados num grau de confiabilidade que se possa analisar para dar veracidade à pesquisa. Os instrumentos de coleta de dados existentes, segundo o autor são: o questionário; a entrevista; o levantamento bibliográfico; a análise de conteúdo; a pesquisa histórica; a pesquisa de medição de atitudes e a técnica de observação.

O instrumento de coleta de dados da pesquisa documental foi a análise de conteúdo. A análise de conteúdo, segundo Moraes (1999), constitui uma metodologia de pesquisa usada para descrever e/ou interpretar o conteúdo de documentos e textos. Essa análise, conduz descrições sistemáticas, tanto qualitativas quanto quantitativas, e ajuda a reinterpretar as mensagens, levando a compreensão de seus significados num nível que vai além de uma leitura comum. Faz parte de uma busca teórica e prática, com um significado especial no campo das investigações sociais. Constitui-se, desta forma uma abordagem metodológica com características e possibilidades próprias. A análise de conteúdo tem oscilado entre o rigor da objetividade dos números e à interpretação, sempre questionada, da subjetividade. Como método de investigação, a análise de conteúdo compreende procedimentos especiais para o processamento de dados científicos. É uma ferramenta, um guia prático para a ação, sempre em busca dos problemas cada vez mais diversificados que 
se propõe a investigar, marcada por uma grande variedade de formas e com vasto campo de adaptabilidade.

A matéria-prima da análise de conteúdo, segundo Bardin (1977) pode constituir-se de material oriundo tanto da comunicação verbal quanto da não-verbal, como jornais, documentos oficiais, livros, revistas, relatos autobiográficos, discos, entrevistas, filmes, fotografias, mídias, etc. Contudo os dados advindos dessas diversificadas fontes chegam ao investigador em estado bruto, para, então ser processado conforme os requintes da pesquisa (interpretação, compreensão e inferência) e a efetiva coleta a que propõe a análise. 0 presente estudo baseia-se na análise de conteúdo de dois tipos distintos de documentos, com o objetivo de identificar conteúdos relativos ao tema empreendedorismo, a saber:

- Diretrizes Curriculares Nacionais, as DCNs dos cursos da área da saúde, em busca de conteúdos voltados à importância do empreendedorismo aos seus egressos. Tal levantamento possui o intuito de validar a pesquisa e o projeto proposto.

- Matrizes curriculares dos cursos da área da saúde, oferecidos na Universidade de São Paulo, Campus de Ribeirão Preto/SP., buscando identificar por meio de um roteiro, os cursos da área da saúde que contemplassem, numa primeira etapa, disciplinas denominadas empreendedorismo ou tema equivalente, e, num segundo momento, disciplinas que possuam em sua denominação, gestão, administração ou temas equivalentes e que tenham em seu conteúdo programático, conteúdos voltados ao tema do empreendedorismo. Os cursos pesquisados são: enfermagem, medicina, farmácia, nutrição, terapia ocupacional, psicologia, ciências biológicas, odontologia, gerontologia, fonoaudiologia e educação física. Tal análise permitiu o entendimento de quais cursos possuíam o tema empreendedorismo em suas matrizes curriculares ou que trabalhavam com o tema em disciplinas correlatas, como gestão ou administração, por exemplo.

Dentre as técnicas de análise de conteúdo tem-se: análise temática ou categorial, de avaliação ou enunciação, análise do discurso, análise léxica ou sintática, análise transversal, dimensional, entre outras. Para esta etapa de análise de conteúdo dos documentos supramencionados, foi elaborado um roteiro descritivo para nortear o levantamento dos 
dados. A síntese das etapas de busca e identificação dos cursos e das respectivas disciplinas está descrita no quadro abaixo:

\begin{tabular}{|c|c|}
\hline & $\begin{array}{c}\text { ETAPA DE PESQUISA DOCUMENTAL } \\
\text { BUSCA DE CURSOS OFERECIDOS PELA USP DA ÁREA DA SAÚDE }\end{array}$ \\
\hline Etapa & Descrição da ação \\
\hline 1 & $\begin{array}{l}\text { Busca dos cursos oferecidos pela Universidade de São Paulo-USP, no endereço eletrônico da } \\
\text { instituição: http://www5.usp.br/ensino/graduacao/cursos-oferecidos/ }\end{array}$ \\
\hline 2 & Identificação dos cursos oferecidos, voltados a área da saúde \\
\hline 3 & $\begin{array}{l}\text { Identificação e seleção e elaboração de quadro dos cursos voltados a área da saúde, oferecidos } \\
\text { pela USP no Campus de Ribeirão Preto/SP. }\end{array}$ \\
\hline 4 & $\begin{array}{l}\text { Acesso aos cursos e análise das matrizes curriculares dos cursos identificados (acesso por meio } \\
\text { dos hiperlinks, gerados a partir do nome de cada curso) }\end{array}$ \\
\hline 5 & Impressão das matrizes curriculares dos cursos da área da saúde \\
\hline 6 & Análise das matrizes, para identificação de disciplinas de empreendedorismo \\
\hline 7 & Análise das matrizes, para identificação de disciplinas de gestão/administração \\
\hline 8 & $\begin{array}{l}\text { Análise das disciplinas de gestão/administração, para identificação de conteúdo voltados ao } \\
\text { empreendedorismo, utilizando as palavras-chave: } \\
\text { - Empreendedorismo } \\
\text { - Perfil empreendedor } \\
\text { - Cultura empreendedora }\end{array}$ \\
\hline 9 & Elaboração do quadro geral com a identificação dos conteúdos localizados \\
\hline 10 & Elaboração dos quadros sínteses dos conteúdos identificados \\
\hline
\end{tabular}

Quadro 1: Quadro: Roteiro para etapa de pesquisa documental

Fonte: A Autora

Já o instrumento de coleta de dados utilizado na pesquisa de campo foi o questionário. O questionário, segundo Cervo e Bervian (2002) trata-se de uma forma de coleta de um conjunto de dados a uma população pré-estabelecida, para verificar a incidência de fatos e relações de fenômenos que ocorrem. O questionário envolve a reunião desses dados coletados de modo sistemático e quantificável, que nos dê parâmetros para uma análise criteriosa e a mais evidenciada possível. O formato de questionário usado foi o questionário estruturado, pelo seu formato único e padronizado para todos os sujeitos da pesquisa, de modo que todos respondam aos mesmos questionamentos, numa mesma sequência e com a mesma escala de respostas. O questionário estruturado, segundo Richardson (2011) é utilizado para obter informações sobre determinada realidade e é tido como uma das etapas do processo de pesquisa mais importante para se obter os dados num 
grau de confiabilidade, buscando promover veracidade ao estudo. A elaboração do questionário foi composta por 4 seções sendo:

- 1a. Termo de Consentimento Livre e Esclarecido, trazendo um detalhamento da pesquisa, seus objetivos, uma breve apresentação da pesquisadora e dados oriundos do processo de aprovação no Comitê de Ética da escola, com o devido protocolo de aprovação;

- 2a. Quadro denominado como Parte I - Perfil dos Respondentes, contendo 10 (dez) questões sócio-demográficas, objetivando identificar características dos alunos que pudessem ser usadas como parâmetros de análises das respostas específicas, da seção seguinte;

- 3a. Quadro denominado como Parte II - Características do Comportamento Empreendedor ${ }^{1}$, contendo 56 (cinquenta e seis) questões específicas sobre características do perfil empreendedor, sendo e, 55 questões objetivas e 01 questão aberta ou discursiva no final do questionário, perguntando o que o(a) aluno(a) entende pelo termo Empreendedorismo. As questões objetivas apresentam as alternativas tipificadas em escala Likert para a elaboração de constructos das características do perfil empreendedor, obedecendo à seguinte ordem:

\begin{tabular}{|l|c|c|c|c|}
\hline $\begin{array}{l}1-\text { Discordo } \\
\text { totalmente }\end{array}$ & $\begin{array}{c}2 \text {-Discordo } \\
\text { parcialmente }\end{array}$ & 3 -Não sei opinar & $\begin{array}{c}4-\text { Concordo } \\
\text { parcialmente }\end{array}$ & $\begin{array}{c}5 \text {-Concordo } \\
\text { totalmente }\end{array}$ \\
\hline
\end{tabular}

Segundo Vieira e Dalmoro (2008), a escala Likert é um tipo de escala de resposta psicométrica usada habitualmente em questionários de pesquisa social. No âmbito das ciências sociais é comum o uso de instrumentos de medida para mensurar a realidade sobre um objeto em estudo. Para realizar essas mensurações, os pesquisadores utilizam instrumentos adequados para que as medidas correspondam efetivamente ao que se deseja medir. Ao responderem a um questionário baseado nesta escala, os pesquisados especificam seu nível de concordância com uma afirmação proposta. Trata-se de instrumentos científicos

\footnotetext{
${ }^{1} \mathrm{O}$ referido instrumento foi elaborado por David McClelland (1987) contendo 55 questões objetivas, tipificadas em escala Likert de 1 a 5 sendo 1 considerando "discordo completamente" a 5 considerando "concordo completamente". É utilizado por vários autores em trabalhos científicos, citados no transcorrer deste trabalho. É aplicado desde 1998, pelo SEBRAE num evento nacional denominado EMPRETEC, que envolve dinâmicas e atividades que desenvolvem as habilidades empreendedoras de seus participantes. O referido autor deste instrumento, será melhor apresentado no capítulo de Referencial Teórico (FONSECA e MUYLDER, 2010)
} 
de observação e mensuração de fenômenos sociais. Dessa forma, a escala foi idealizada com o objetivo de medir a intensidade das atitudes e opiniões da forma mais objetiva possível. A utilização de escalas de mensuração requer cuidados essenciais para o alcance de resultados satisfatórios, confiáveis e que permitam conclusões apropriadas (VIEIRA e DALMORO, 2008).

De acordo com Hair et.al (2005), o método de escala Likert traz alguns critérios importantes destacados na literatura e que: as escalas devem ser simétricas, ou seja, conter o mesmo número de categorias positivas e negativas; recomenda-se que a escala tenha um ponto central, de modo que os entrevistados possam selecionar essa opção em caso de indecisão ou neutralidade; é recomendável que a apresentação das escalas sejam iguais ou muito parecidas em termos de estrutura e níveis; as alternativas positivas e negativas devem estar na mesma região para evitar confundir o participante; ser mensurável em termos de validade e qualidade estatística. Vale ressaltar que todos os critérios citados foram mantidos nesta pesquisa.

Cabe ressaltar ainda que o instrumento de pesquisa utilizado, é consagrado pelos pesquisadores e estudiosos do tema empreendedorismo no Brasil, utilizado em várias pesquisas de campo tendo como sujeitos, alunos do ensino superior, como será apresentado nos tópicos sobre empreendedorismo e o seu processo de ensino. Além disso, periodicamente passa por novas validações, como é o caso do trabalho de Marion-Santos e Paixão (2013). Este instrumento está nos Apêndices deste trabalho e foi desenvolvido por David McClelland (1987), pesquisador reconhecido na área e autor de vários materiais sobre empreendedorismo e as características comportamentais empreendedoras. Seus estudos são reconhecidos mundialmente por meio de eventos que objetivam desenvolver o perfil empreendedor na sociedade.

O processo de análise dos dados desse instrumento de pesquisa para se analisar os dados qualitativos é composto por algumas etapas, descritas a seguir:

- Análise por categorização que tem a função de um processo afunilativo, composto por etapas e com desmembramento dos textos em unidades, ou categorias, criadas a partir da identificação de termos ou símbolos, que faça sentido um reagrupamento (BARDIN, 1977). As categorias de análise, ainda segundo a autora, podem ser criadas a priori, ou seja, a partir da teoria e antes da coleta dos dados, ou a posteriori, quando já se tem a pesquisa 
aplicada e os dados coletados. Ainda para a autora, a análise categorial exige inicialmente uma classificação de elementos em suas características pré-definidas, para assim reorganizar um reagrupamento, em que as categorias reúnem grupos de elementos com características comuns, distinguindo-as por meio da técnica de enunciação.

- Análise de enunciação que segundo Bardin (1977), busca compreender o significado das respostas, por meio do conteúdo ou enunciado do participante. É o processo de segmentar os textos das respostas, em unidades menores, sucintas, podendo ser orações, sentenças, parágrafos ou tópicos, de modo que se possa segmentar o texto, reduzindo-o para o mais simples e curto possível. A análise de conteúdo, por meio da técnica de análise por enunciação, em si, já caracteriza como categoria de análise a posteriori, utilizando os dados coletados na pesquisa, por entender que as respostas poderiam apontar elementos diversificados, possibilitando uma análise mais imersiva (MINELLO, 2014).

- Análises de leitura flutuante, para se chegar ao mapeamento e agrupamento de termos e símbolos na categorização da análise de conteúdo, que resultou em infogramas denominada nuvem de palavras ${ }^{2}$, levando em conta o número de repetições de termos identificados na leitura flutuante. Esta análise leva em conta o quantitativo de vezes que um determinado termo aparece ou, se repete nas respostas abertas e por eles, tem-se uma base das interpretações dos respondentes sobre o tema pesquisado (BARDIN, 1977); e,

- Discussão por meio de proposições teóricas, que orientam a coleta e análise dos dados, baseando-se na literatura e contribuem para o entendimento da realidade, permitindo a análise do objeto estudado a partir de um referencial teórico existente, permitindo criar uma discussão entre os autores dos temas, paralelo com os resultados obtidos da pesquisa de campo (YIN, 2015).

Já o processo de análise dos dados quantitativos, contou com o rigor dos procedimentos estatísticos, fazendo uso de sistemas específicos inicialmente por meio do

\footnotetext{
${ }^{2}$ Nuvem de palavras (word cloud) é um gráfico digital que mostra o grau de frequência das palavras em um texto. Quanto mais a palavra é utilizada, mais chamativa é a representação dessa palavra no gráfico. As palavras aparecem em fontes de vários tamanhos e em diferentes cores, indicando o que é mais relevante e o que é menos relevante no contexto. Esse recurso pode ser utilizado em atividades de interpretação e produção de textos. $O$ desenvolvedor Jason Davies criou o Word Cloud programa gratuito que cria nuvens de palavras. É só usar: www.jasondavies.com/wordcloud/\#\%2F\%2Fwww.jasondavies.com\%2Fwordcloud\%2Fabout\%2F. Disponível em: http://www.arede.inf.br/crie-a-sua-nuvem-de-palavras/
} 
software $\mathrm{Excel}^{3}$, na compilação dos dados e posteriormente transferidos para o sistema SPSS e sistema $R^{4}$, que possibilitaram a análise descritiva da pesquisa quanti, com quadros apresentando média, mediana e ponderações, além das análises de dispersão entre as variáveis pesquisadas. Também foram aplicadas outras análises como $\alpha$ de Crombach para validar os resultados em termos de confiabilidade (STASINOPOULOS e RIGBY, 2007).

Para a realização da análise dos dados quantitativos foi utilizado o programa $R$ ( $R$ CORE TEAM, 2018) versão 3.5.3 através da biblioteca GAMLSS (STASINOPOULOS e RIGBY, 2007). A classe de Modelos Aditivos Generalizados para Posição, Escala e Forma (GAMLSS em inglês) é adequada, sobretudo, para modelagem da variável resposta quando ela não segue uma distribuição da família exponencial e nos casos em que o regressando exibe heterogeneidade, ou seja, quando a escala ou a forma da distribuição da variável resposta mudam com as variáveis explanatórias (FLORÊNCIO, 2010).

Seja $y^{T}=\left(y_{1}, \ldots, y_{n}\right)$ um vetor de tamanho $\mathrm{n}$ da variável resposta com função densidade $f\left(y_{i} \mid \theta^{i}\right)$, onde $\theta^{i}=\left(\theta_{1 i}, \theta_{2 i} \theta_{3 i} \theta_{4 i}\right)=\left(\mu_{i}, \sigma_{i} v_{i} \tau_{i}\right)$, e seja $\mathrm{k}=1,2,3,4$ e seja $g_{k}($.$) uma função de ligação monótona que relaciona os parâmetros com as variáveis$ independentes a partir das equações

$$
\begin{aligned}
& g_{1}(\boldsymbol{\mu})=\boldsymbol{\eta}_{1}=\mathbf{X}_{1} \boldsymbol{\beta}_{1}+\sum_{j=1}^{J_{1}} h_{j 1}\left(\mathbf{x}_{j 1}\right) \\
& g_{2}(\boldsymbol{\sigma})=\boldsymbol{\eta}_{2}=\mathbf{X}_{2} \boldsymbol{\beta}_{2}+\sum_{j=1}^{J_{2}} h_{j 2}\left(\mathbf{x}_{j 2}\right) \\
& g_{3}(\boldsymbol{\nu})=\boldsymbol{\eta}_{3}=\mathbf{X}_{3} \boldsymbol{\beta}_{3}+\sum_{j=1}^{J_{3}} h_{j 3}\left(\mathbf{x}_{j 3}\right) \\
& g_{4}(\boldsymbol{\tau})=\boldsymbol{\eta}_{4}=\mathbf{X}_{4} \boldsymbol{\beta}_{4}+\sum_{j=1}^{J_{4}} h_{j 4}\left(\mathbf{x}_{j 4}\right) .
\end{aligned}
$$

Em que $\mu, \sigma$, v e $\tau$ são vetores de comprimento $n, \beta_{k}=\left(\beta_{1 \mathrm{k}}, \beta_{2 \mathrm{k}}, \ldots, \beta_{\mathrm{j}} \mathrm{k}\right)$ é um vetor de comprimento $\mathrm{j}^{\mathrm{k}}$ e $\mathrm{X}_{\mathrm{k}}$ é a matriz de delineamento de ordem $\mathrm{n} \times \mathrm{j}^{\mathrm{k}}$. A função $\mathrm{h}_{\mathrm{jk}}$ é uma função não aditiva não paramétrica da variável explicativa $X_{\mathrm{k}}$ avaliada em $\mathrm{X}_{\mathrm{jk}}$.

\footnotetext{
${ }^{3}$ Software Excel, programa de computador do pacote Office da Microsoft Corporation voltado para elaboração de planilhas, gráficos e relatórios gerenciais STASINOPOULOS, (2007).

${ }^{4}$ Software R, de código aberto voltado a análises estatísticas
} 
A seleção da distribuição da variável dependente foi realizada por meio do critério de informação de Alaike Generalizado, definido por GAIC $=-2 \mathrm{l}(\hat{\theta})+\mathrm{b} * \mathrm{df}$, em que $\mathrm{l}(\hat{\theta})$ é a função de verossimilhança, b é um parâmetro de penalização e df denota os graus de liberdade do modelo. No presente trabalho adotou-se o valor de $b=2$ (AKAIKE, 1974). Em Stasinopoulos (2008) são apresentadas todas as distribuições abrangidas na classe GAMLSS.

As variáveis independentes que foram utilizadas foram Unidade (Enf-1, Enf-2, Enf-3), Ano (Primeiro e Último). Negócio Próprio (Sim/Não) e Empreendedorismo na família (Parente $1^{\circ}$, Parente $2^{\circ}$, Não). A seleção das variáveis independentes, efeitos principais e interações de 2 a ordem, também foi realizada por meio do Critério de Informação de Akaike Generalizado (GAIC) e a comparação entre modelos ajustados foi realizada por meio do teste da Razão de Verossimilhança. A adequação do modelo pode ser verificada por meio do teste de Normalidade de Kolmogorov-Smirnov sobre os resíduos do modelo para verificar sua adequação com a distribuição Normal Padrão (STASINOPOULOS e RIGBY, 2007).

Cabe ressaltar que esta etapa de análise estatística da pesquisa quantitativa teve o apoio do setor de estatísticos da escola, que realizaram a compilação e aplicação das equações por meio dos sistemas já descritos. Este processo de análise seguiu uma sequência de operações descritas por McClelland (1987), em vários trabalhos, especialmente de Krüger (2016 e 2019), de Caggy, et.al (2017), de Mota (2013), de Torres (2018), Muraro e Verruck (2012), de Fernandes (2014), entre outros trabalhos apresentados no referencial teórico.

Outras técnicas aplicadas na etapa de análise quantitativa desta pesquisa, como distribuição dos dados e análise de dispersão, serão detalhadas no capítulo de resultados da pesquisa de campo com o intuito de deixar próximos, os gráficos e a forma de interpretá-los.

Foram, portanto, apresentados, todos os elementos da presente pesquisa. Tais elementos possuem a função essencial de mapear o trabalho a ser realizado, tanto em relação ao seu conteúdo como em relação às suas etapas. Segundo Minayo (2012), tal mapeamento define o percurso teórico-metodológico e tem origem na relação dialética entre o exercício de se criar marcos conceituais, articulando-os com a prática. Torna-se complexa a tarefa de escolha do arcabouço teórico que lhes possibilite a apreensão empírica da realidade a ser estudada, o qual só pode ser apropriado após vasta busca e a consequente 
compreensão das faces do problema que permitam estabelecer conexões e construir mediações.

Trata-se de um plano de pesquisa, um planejamento das etapas a serem percorridas (YIN, 2015). O quadro a seguir sintetiza estes aspectos metodológicos e ilustra seus componentes para apresentar o esquema de todo o processo adotado: 


\section{QUADRO: ASPECTOS METODOLÓGICOS DA PESQUISA}

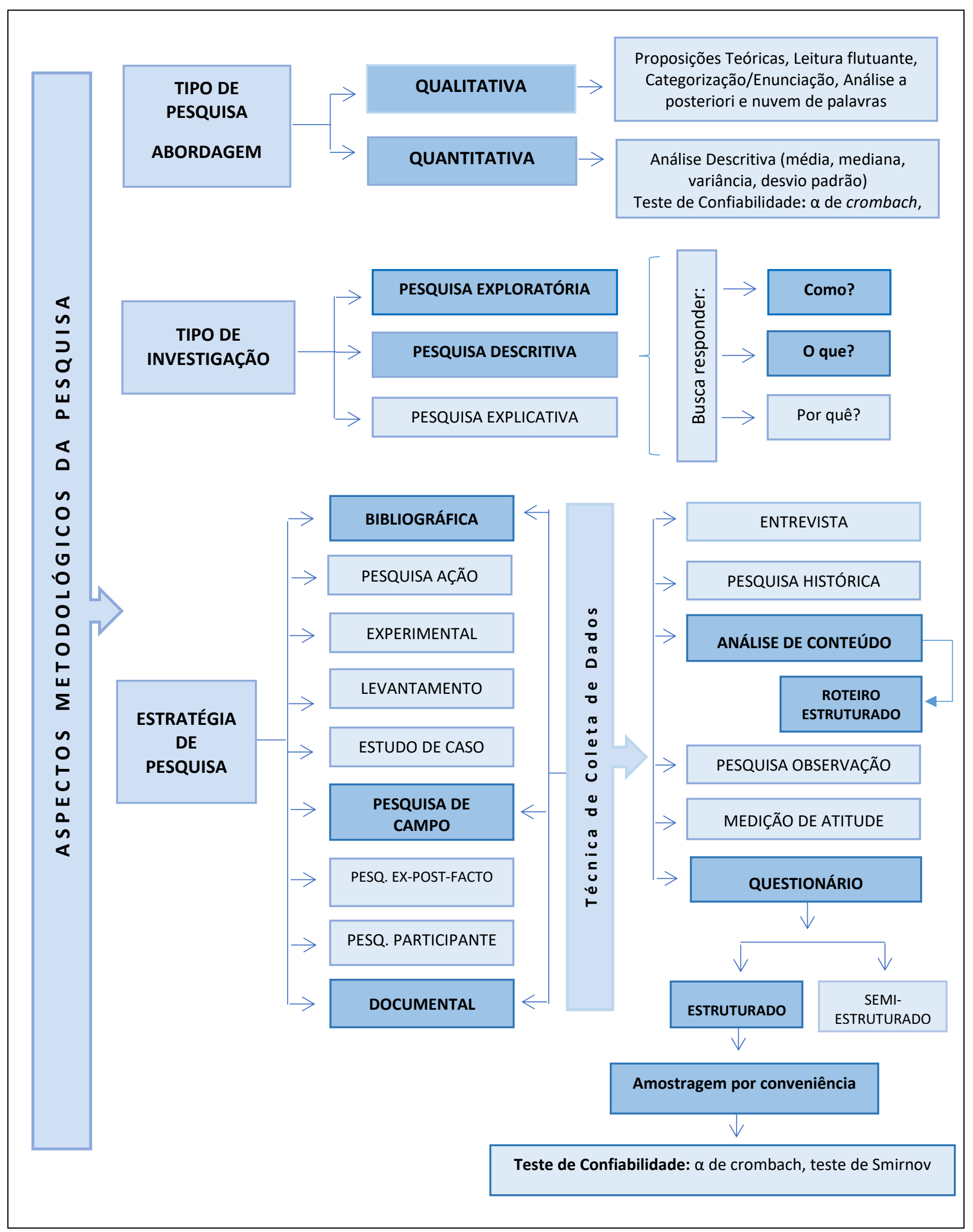

Quadro 2: Aspectos Metodológicos da Pesquisa Fonte: Adaptado de Souza (2007) 
O quadro, a seguir, traz o escopo da pesquisa, sob os aspectos metodológicos, a luz de seus objetivos geral e específicos, buscando responder ao problema de pesquisa:

\begin{tabular}{|l|l|l|l|}
\hline \multicolumn{1}{|c|}{ Objetivo Geral } & \multicolumn{1}{|c|}{ Objetivos Específicos } & $\begin{array}{c}\text { Tipo de } \\
\text { Pesquisa }\end{array}$ & $\begin{array}{l}\text { Instrumento metodológico } \\
\text { e/ou }\end{array}$ \\
\hline Técnica de Coleta de Dados
\end{tabular}

Problema de Pesquisa

Apesar da inexistência de disciplinas voltadas ao ensino do empreendedorismo, é possível afirmar que o aluno terá adquirido no transcorrer do curso, as habilidades empreendedoras, elencadas no perfil empreendedor, segundo as características comportamentais empreendedoras de David McClelland (autoconfiança, liderança e trabalho em equipe; assumir riscos calculados; dedicação e comprometimento; planejamento; persistência; busca de oportunidades; inovação; delegação de autoridade e iniciativa)?

Quadro 3: Mapeamento da Pesquisa em termos metodológicos, a luz dos objetivos propostos Fonte: A autora 


\subsubsection{Participantes da pesquisa e aspectos práticos}

O objeto de pesquisa são três cursos de graduação em Enfermagem de três instituições de ensino superior, sendo uma pública e duas privadas do interior do estado de São Paulo-SP. Os participantes da pesquisa são alunos desses três cursos de graduação, ingressantes e concluintes.

O critério de seleção desses cursos foi definido por conveniência e pela facilidade no acesso aos alunos, aos docentes e direção institucional, instâncias necessárias para formalizar autorizações da coleta de dados com os discentes, caracterizando desta forma, como amostra não probabilística, por ter sido uma seleção da própria pesquisadora, por conveniência, como tipifica Marconi e Lakatos (2004). Cabe dizer que a região possui outras instituições que oferecem o referido curso, mas que não foram incluídos nesta pesquisa, o que pode vir a ser objeto de trabalhos futuros. Como restrição à participação do aluno foi imposta a maioridade de idade. Os cursos serão assim identificados, como Enf-1, Enf-2 e Enf3, para manter resguardadas suas identificações, respeitando critérios de sigilosidade:

- Enf-1: Curso pertencente a uma instituição pública, que oferece 8 cursos na área da saúde, 3 cursos na área de negócios, 3 cursos na área de engenharia e 5 cursos na área de educação.

- Enf-2: Curso pertencente a uma instituição privada, que oferece 5 cursos na área da saúde, 3 cursos na área de negócios, 4 cursos na área de engenharia e 3 cursos na área de educação.

- Enf-3: Curso pertencente a uma instituição privada, que oferece 2 cursos na área da saúde, 3 cursos na área de negócios, 3 cursos na área de engenharia e 3 cursos na área de educação.

Os objetivos dos cursos de enfermagem das instituições são:

\begin{tabular}{|c|c|c|}
\hline Enf-1 & Enf-2 & Enf-3 \\
\hline $\begin{array}{l}\text { O objetivo do curso de } \\
\text { Graduação em } \\
\text { Bacharelado/Licenciatura em } \\
\text { Enfermagem está em } \\
\text { consonância às diretrizes da } \\
\text { Universidade de São Paulo, as } \\
\text { Diretrizes Curriculares }\end{array}$ & $\begin{array}{l}\text { Proporcionar aos educandos } \\
\text { conhecimentos para que } \\
\text { desenvolvam competências e } \\
\text { habilidades técnico-científicas } \\
\text { e ético-político-sociais- } \\
\text { educativas, de investigação } \\
\text { científica, de comunicação, }\end{array}$ & $\begin{array}{l}\text { Habilitar o enfermeiro para } \\
\text { atuar na assistência individual } \\
\text { e coletiva, com base em uma } \\
\text { sistemática de assistência de } \\
\text { enfermagem, com } \\
\text { competência técnica e ética. }\end{array}$ \\
\hline
\end{tabular}


Nacionais do Curso de Graduação em Enfermagem e à Lei do Exercício Profissional do Enfermeiro, segundo Conselho Federal de Enfermagem. $O$ ensino de graduação em Enfermagem se constitui na etapa inicial da vida acadêmica do estudante para a formação do profissional enfermeiro. $\mathrm{O}$ curso deve oferecer oportunidade ao estudante para o desenvolvimento da capacidade de análise crítica para desenvolver e gerenciar o processo do cuidado de enfermagem, individual e coletivo, na perspectiva da integralidade, do raciocínio clínico e epidemiológico, nos diferentes contextos de prática profissional, em consonância com a realidade social e de saúde; preparar o estudante para lidar com novas situações, com iniciativa, criatividade, flexibilidade e ética; capacitar o estudante para utilizar na prática diária a buscar e produzir conhecimentos tecnológicos e metodológicos na área da saúde para qualificar o cuidado de enfermagem, uma vez que se trata de uma atividade reflexiva e investigativa, bem como atuar como agente de mudanças no sistema de saúde.

Objetiva também desenvolver o currículo de forma integrada a partir dos saberes essenciais e complementares norteados por eixos que se articulam. Pressupõe que o estudante terá oportunidade de desenvolver visão crítica e participar da construção e socialização do conhecimento em Saúde e em Enfermagem. administração e gerência, capazes de exercer observação, análise e síntese para desempenho sua profissão de forma reflexiva, crítica e criativa, capazes de se apropriar e recriar o conhecimento, comprometidos com a integralidade, equidade e universalidade da assistência com vistas ao atendimento do Sistema Único de Saúde, da saúde complementar e da realidade social;

\section{Propiciar que a formação} contribua para a qualificação permanente dos educandos, com o desenvolvimento profissional, ainda que evoluam condições de avaliar e tomar decisões profissionais adequadas às situações e promovam diferentes formas de interação relacional com outros profissionais de saúde e com o público em geral; 3 . Possibilitar a formação de um profissional capaz de atuar, acadêmica e profissionalmente, sob os princípios éticos e na perspectiva da inclusão, com as responsabilidades que norteiam a intervenção do Enfermeiro.
Habilitar o enfermeiro para a prática administrativa de enfermagem e organização de serviços de saúde.

Habilitar o enfermeiro para o desenvolvimento de práticas educativas em saúde e atuar na formação de recursos humanos em serviço.

Desenvolver no aluno a capacidade de construir os conhecimentos científicos da sua prática profissional e desenvolver atividades de pesquisa para o aprimoramento da profissão.

Compreender e aplicar os valores políticos e éticos da profissão, assistindo o ser humano de forma holística, reconhecendo sua dignidade, considerando seu poder de criatividade e estimulando suas potencialidades.

Proporcionar ao educando uma formação que possibilite o desenvolvimento técnico e científico para a atuação profissional, com vistas à promoção, prevenção e recuperação da saúde, tanto em nível individual quanto coletivo. Para isso, tem como base uma concepção interdisciplinar, que possibilita uma visão integral do homem sadio no contexto sócio, econômico e cultural e no seu processo de adoecer. Desta forma, a formação profissional do curso visa atender às reais necessidades de saúde da população, no que diz respeito às competências de enfermagem.

Quadro 4: Objetivos curriculares dos cursos pesquisados

Fonte: Autora 
Quanto à carreira e perfil do egresso:

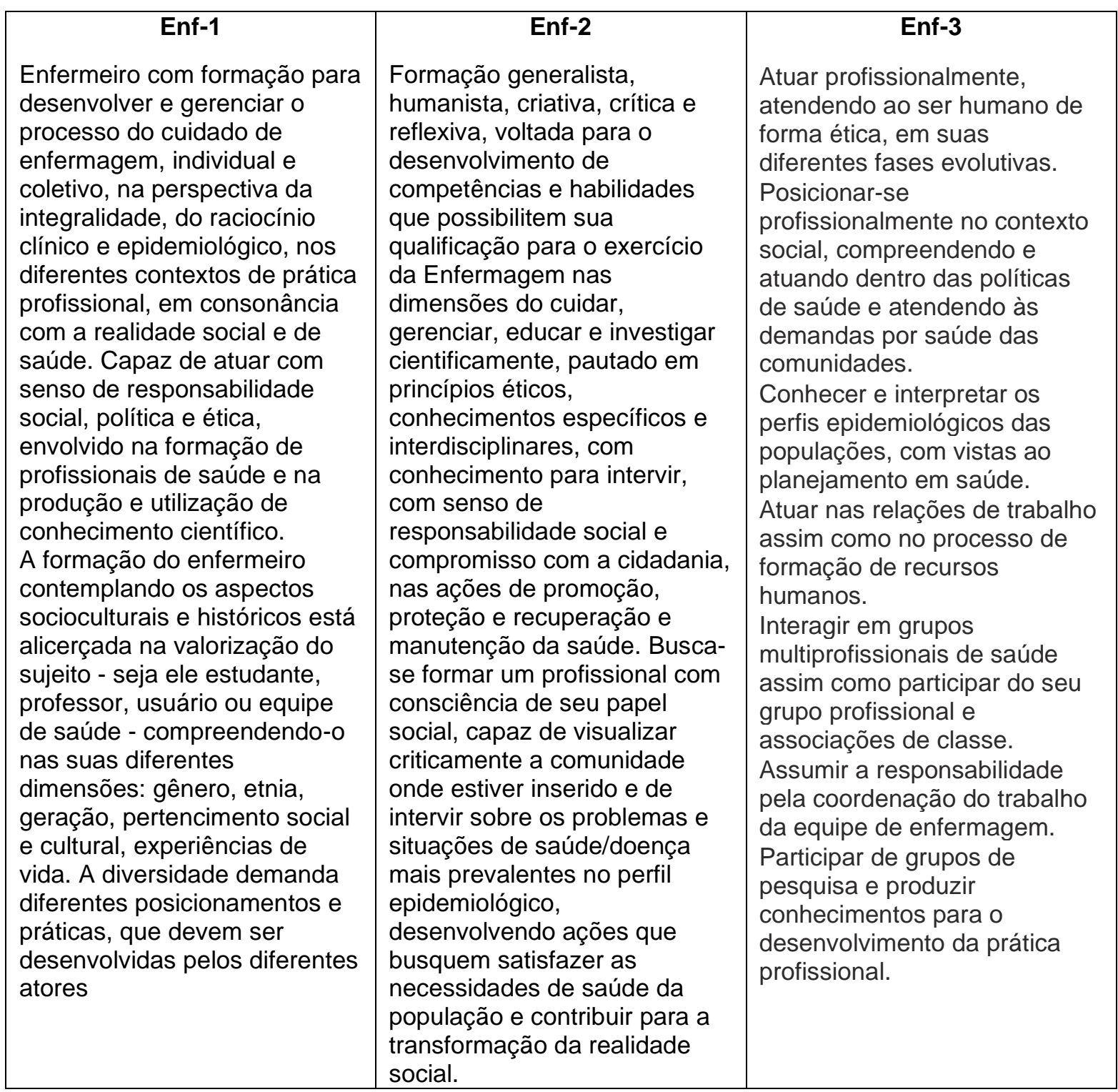

Quadro 5: Perfil do egresso dos cursos pesquisados

Fonte: Autora

Quanto à sua matriz curricular, temos:

\begin{tabular}{|l|l|l|}
\hline \multicolumn{1}{|c|}{ Enf-1 } & \multicolumn{1}{c|}{ Enf-2 } & \multicolumn{1}{c|}{ Enf-3 } \\
1ํ. Período & 1o semestre & SEMESTRE 1 \\
A Inserção do Estudante na & Análise Textual & Anatomia: \\
Universidade & Anatomia Sistêmica & Citologia e Histologia: \\
Integralidade do Cuidado em & Bioquímica & História da Enfermagem: \\
Saúde I & Relacionamento e & Direitos Humanos e \\
Anatomia & Comunicação em Enfermagem & Legislação e Ética \\
Fisiologia & Biologia Celular & Profissional na \\
Microbiologia & Planejamento de Carreira e & Enfermagem: \\
Processo Saúde-doença & Sucesso Profissional & Meio Ambiente e Promoção \\
\hline
\end{tabular}


Biologia Celular, Histologia e Embriologia

Saúde Ambiental

Sociologia

História da Enfermagem

$2^{\circ}$. Período

Imunologia

Políticas e Organização dos

Serviços de Saúde

Bioestatística e Ética

Abordagem Antropológica de

Saúde e Doença

Psic. do Desenvolvimento

\section{3‥ Período}

Semiologia e Semiotécnica

Fund.de Enfermagem

Epidemiologia

Enfermagem em Genética e

Genômica

Patologia Geral Aplicada à

Enfermagem

Bioquímica e Farmacologia

Psicologia da Saúde

4․ Período

Metodologia da Pesquisa Científic

Enfermagem em Gerontologia

Integralidade do Cuidado em Saú

Nutrição

Parasitologia

Integralidade do Cuidado em

Saúde II

Cuidados em Saúde Mental

5‥ Período

Saúde do Trabalhador

Cuidado Integral ao Adulto e ao

Idoso Hospitalizados em

Situação Clínica

Dietoterapia

Bioética e Legislação em Enf.

Cuidado Integral em Saúde

Mental e Enf. Psiquiátrica

Processos pedagógicos em

enfermagem

\section{6‥ Período}

Atividade Acadêmico-científico 1

Cuidado Integral ao Adulto e Idc

Perioperatório

Administração Aplicada a Enferı Hospitalar
Direitos Humanos e

Legislação e Ética

$2^{\circ}$ semestre

Anatomia Clínica

Sistematização do Cuidar I

Ética, Legislação e Exemplos

Profissionais em Enfermagem

Histologia e Embriologia

História da Enfermagem

Imunologia Básica

\section{$3^{\circ}$ semestre}

Fisiologia Humana

Fundamentos

Socioantropológicos da Saúde Genética

Enfermagem em Saúde da

Família

Sistematização do Cuidar II

Microbiologia Básica para

Enfermagem

\section{4ํㅗㄹ semestre}

Ensino Cínico em Saúde

Coletiva

Sistematização do Cuidar III

Farmacologia para

Enfermagem

Educação em Enfermagem Biofísica

\section{5ㅇ semestre}

Fundamentos da Estatística

Metodologia Científica

Nutrição

Parasitologia Básica em

Enfermagem

Patologia em Enfermagem

Ensino Clínico em Saúde do

Adulto Idoso

6을 semestre

Ensino Clínico em Saúde da

Criança e do Adolescente

Ensino Clínico em Saúde da

Mulher
Microbiologia e Imunologia:

Filosofia:

\section{SEMESTRE 2}

Bioquímica:

Fisiologia Humana:

Genética:

Psicologia Aplicada à

Saúde:

\section{SEMESTRE 3}

Farmacologia:

Fundamentos: Semiologia

e Semiotécnica:

Introdução a Saúde Mental:

Parasitologia:

Prática Integrada do Cuidar I:

Saúde e Sociedade:

\section{SEMESTRE 4}

Bioestatística:

Comunicação e Expressão:

Enfermagem na Saúde da

Criança e do Adolescente:

Enf na Saúde da Mulher:

Enferm. na Saúde Adulto

Políticas de Saúde e Saúde da Família:

Prática Integrada Cuidar II:

\section{SEMESTRE 5}

Assistência em

Enfermagem Cirúrgica:

Assistência em

Enfermagem Clínica:

Didática Aplicada a Saúde: Nutrição e Dietoterapia:

Prática Integrada do Cuidar III:

\section{SEMESTRE 6}

Enfermagem Obstétrica e Ginecológica:

Enfermagem em Urgências e Emergências: 


Cuidado Integral à Criança e ao
Cuidado integral à mulher

$7^{\text {o․ Período }}$
Metodologia do Ensino de
Enfermagem I
Promoção de Saúde na
Educação Básica
Didática II
Psicologia da Educação II
Urgência e Emergência em Enf
Cuidado Integral ao Adulto e
Idoso no Perioperatório

8․ Período

Trabalho de Conclusão Curso

Urgência e Emergência em

Enfermagem

Organização e Gestão em

Saúde e Enfermagem na

Atenção Hospitalar

Gestão em Saúde e At. Básica

9․ Período

Urgência e Emergência em

Enfermagem

Estágio Curricular: Enfermagem

na Área Hospitalar

Organização e Gestão em

Saúde e Enfermagem na

Atenção Básica

Trabalho de Conclusão Curso

$10^{\circ}$ semestre

Estágio Curricular: Enfermagem na Atenção Básica

Metodologia do Ensino de

Enfermagem II

Urgência e Emergência em

Enfermagem

Trabalho de Conclusão de

Curso $7^{\circ}$ semestre

Tópicos em Libras: Surdez e

Inclusão

Organização e Políticas de

Saúde

Enfermagem em Saúde

Ambiental

Ensino Clínico em Cirurgia

Ensino Clínico em Saúde

Mental

$8^{\circ}$ semestre

Ensino Clínico em Alta

Complexidade

Saúde do Trabalhador

Tanatologia

Administração e Gerência em

Enfermagem

9o semestre

Comunicação nas Empresas

Direitos Humanos

História dos Povos Indígenas

e Afrodescendentes

Urgência e Emergência em

Enfermagem

Psicologia nas Organizações

Estágio Curricular:

Enfermagem na Atenção

Básica

$10^{\circ}$ semestre

Assist. Enfermagem Oncologia

Assist. Enf. Depend. Química

Enfermagem na Prev. e

Contração de Infecções

Hospitalares

Auditoria de Enfermagem

Gestão Ambiental
Enfermagem Pediátrica e

Neonatal:

Enfermagem Psiquiátrica:

Prática Integrada do Cuidar IV:

\section{SEMESTRE 7}

Metodologia de Pesquisa:

Sistemas de Informações

em Saúde:

Teoria Geral da

Administração:

Vigilância em Saúde:

Libras:

SEMESTRE 8

Administração dos Serviços de Enfermagem na Rede

Básica: Organização e

Gestão:

Administração dos Serviços de Enfermagem Hospitalar Organização e Gestão

\section{SEMESTRE 9}

Estágio Curricular:

Enfermagem na Atenção

Básica

Monografia: -

Educação para as

Relações Etnico-Raciais:

Pratica Integrada Cuidar V:

Estágio Curricular

Supervisionado I:

\section{SEMESTRE 10}

Estágio Curricular

Supervisionado II:

Urgência e Emergência em

Enfermagem

Trabalho de Conclusão de

Curso

https://www.saoluis.br/graduac ao/enfermagem/4

https://uspdigital.usp.br/jupiterweb/li

starGradeCurricular?codcg $=22 \&$ cod

https://portal.estacio.br/media/372 cur $=22013 \&$ codhab $=0$ \&tipo $=N$

7098/matriz-enfermagem.pdf

Quadro 6: Matriz curricular dos cursos pesquisados

Fonte: Autora 
Os discentes dos três cursos participantes da pesquisa, são ingressantes e concluintes, apresentados no quadro a seguir:

\begin{tabular}{|c|l|l|}
\hline Instituição & Número de alunos ingressantes & Número de alunos concluintes \\
\hline Enf-1 & 130 alunos & 108 alunos \\
\hline Enf-2 & 140 alunos & 70 alunos \\
\hline Enf-3 & 55 alunos & 28 alunos \\
\hline
\end{tabular}

Quadro 7: Alunos participantes da pesquisa

Fonte: Autora

A pesquisa foi aplicada pela própria pesquisadora, de forma presencial, sem relação de autoridade entre pesquisador e pesquisado, utilizando uma abordagem direta para apresentação do estudo, seus objetivos e o devido convite. A aplicação da pesquisa com os alunos ingressantes ocorreu em disciplinas oferecidas no semestre em que os alunos estiveram presentes em sala de aula. Foi solicitada via e-mail, autorização ao docente responsável pela disciplina, para conversar com os alunos e apresentar a pesquisa, para assim, convidá-los para leitura e aceite do Termo de Consentimento Livre e Esclarecido - TCLE e, na sequência, participarem da pesquisa respondendo ao questionário, o que levou em torno de 06 a 09 minutos.

A pesquisadora também se disponibilizou a atender os alunos de forma presencial, além do e-mail e telefone, informados no referido termo de consentimento.

\subsection{Considerações Éticas}

A presente pesquisa atendeu às regras estabelecidas pela legislação vigente e cumpriu com os parâmetros éticos exigidos pelo Comitê de Ética em Pesquisa CEP-EERP-USP da escola o qual a pesquisadora tem vínculo. Por ser uma pesquisa envolvendo sujeitos, alunos de cursos de enfermagem, foi necessário, como condição prévia à submissão do projeto ao CEP, submeter o projeto à Comissão de Graduação da EERP/USP, para apreciação e emissão de parecer favorável. Após obtenção do ofício de autorização expedido pela 
referida comissão, a pesquisa passou pelo processo de análise junto ao CEP-EERP por meio de cadastro e envio pela plataforma Brasil ${ }^{5}$.

Após o processo de análise e devidas correções, o parecer foi favorável. Com parecer favorável em mãos, foi possível contatar as demais instituições e entrar com os protocolos de anuência junto às reitorias e às coordenações dos cursos. De posse da documentação de liberação de realização da pesquisa com os alunos dos três cursos, foi possível traçar um planejamento para a aplicação do instrumento de pesquisa, juntamente com o termo de consentimento, como exigem os parâmetros legais. Ambos documentos, encontram-se ao final do trabalho, como anexos.

\footnotetext{
${ }^{5}$ A Plataforma Brasil é um sistema eletrônico criado pelo Governo Federal para centralizar e sistematizar o recebimento dos projetos de pesquisa que envolvam seres humanos. Trata-se de uma base nacional e unificada de registros de pesquisas nos Comitês de Ética em todo o país, propiciando ainda à sociedade o acesso aos dados públicos de todas as pesquisas aprovadas. Acesso: http://plataformabrasil.saude.gov.br/login.jsf.
} 


\section{REVISÃO DA LITERATURA}

"Ninguém sabe tudo. Ninguém ignora tudo. Todos nós sabemos alguma coisa. Todos nós ignoramos alguma coisa. Por isso estamos a aprender, sempre".

Paulo Freire

Este capítulo destina-se a delinear o cenário em que vem sendo estudado o tema empreendedorismo, suas aplicações, dimensões e o ensino do empreendedorismo no contexto educacional. Por meio de revisão da literatura foi possível conhecer as principais teorias sobre o tema, além de trazer discussão sobre o ensino do empreendedorismo nas instituições de ensino superior e da importância da educação empreendedora no fomento e desenvolvimento de novos profissionais. Nessa direção, apresenta-se a evolução do tema empreendedorismo na atualidade, dando enfoque ao contexto a formação profissional que impulsionou a inserção do empreendedorismo no cenário educacional e a introdução da proposta de educar para empreender.

\subsection{EMPREENDEDORISMO: Contexto Histórico}

O fenômeno do empreendedorismo pode ser entendido como um dos reflexos das transformações do homem no mundo. Se considerarmos a história humana, baseada nos registros de sua evolução, é possível afirmar que o homem primitivo já possuía características empreendedoras, pois para sobreviver, era necessária alguma destreza na fabricação e no manuseio de ferramentas para caça de animais, como estratégia para sua sobrevivência (VERGA e SILVA, 2014). O conceito de Homo Habilis, ancestral à raça humana, surgiu há aproximadamente 2 milhões de anos e já trazia esta prática de caça (HISRICH, 2004).

Alguns milhares de anos se passaram e um importante salto para o empreendedorismo ocorreu com as grandes civilizações antigas, como os egípcios na construção das pirâmides, que, poderiam levar até 20 anos de trabalho e 30 mil homens. $\mathrm{Na}$ 
agricultura também nota-se ações empreendedoras, que aproveitavam a cheia do rio Nilo para o preparo da terra e plantio da safra seguinte (BARLACK, 2014).

Mas, o que demonstravam apenas esforços para a sobrevivência dos homens primitivos e demonstração do conhecimento acumulado ao longo dos séculos, como as edificações egípcias, ganhou contornos econômicos a partir do século XV e XVI, quando surgiu as grandes feiras e com elas, as oportunidades de comercialização de mercadorias entre os povos. Holandeses, ingleses, portugueses e espanhóis foram os representantes desse movimento, levando suas missões empreendedoras pelos demais continentes. Esse movimento se expandiu para além das demandas da época, momento em que os mercadores ousaram em desbravar novos mercados, tentando negociar uma produção excessiva, forjando o período mercantilista, embrião de tudo o que conhecemos atualmente (HISRICH, 2004).

Outra grande fase histórica que trouxe mudanças significativas para o contexto do mundo do trabalho, decorrentes do surgimento da energia elétrica, da substituição do ferro pelo aço e do uso do petróleo substituindo o vapor como combustível. Entre o final do século XVIII e início do século XIX inicia-se as revoluções dos sistemas produtivos, tendo por base, o surgimento do Taylorismo ${ }^{6}$ com a especialização do trabalho e fragmentação das tarefas e do Sistema Fordista ${ }^{7}$ de produção em massa e padronização das operações. Tais mudanças ficaram conhecidas como Revolução Industrial e com ela o surgimento da classe operária em substituição aos artesãos da época (MAXIMIANO, 2015).

Essa ascensão da sociedade capitalista gerou uma crise que se instalou décadas depois, levando os mercados a uma reestruturação dos seus processos produtivos, revolucionando novamente a base técnica da produção e direcionando os processos produtivos para uma substituição do sistema fordista para atender às novas demandas de

\footnotetext{
${ }^{6}$ Taylorismo: Taylorismo consiste num sistema de organização industrial desenvolvido por Frederick Taylor, economista e engenheiro mecânico estadunidense. O principal objetivo desta técnica é otimizar as tarefas desempenhadas pelos operários nas empresas, através da organização das tarefas e divisão de funções dos trabalhadores, movimento conhecido como ORT - Organização Racional do Trabalho. (MAXIMIANO, 2015).

${ }^{7}$ Sistema Ford: modelo de processo produtivo desenvolvido por Henri Ford na primeira metade do século XX e que revolucionou a indústria automobilística. É um modelo de produção baseado pela produção em massa, pela fragmentação das funções na linha de montagem, onde o trabalhador exerce uma única tarefa dentro deste processo de produção se tornando especialista no desempenho do que faz. (MAXIMIANO, 2015).
} 
mercado para o sistema $\operatorname{Toyota}^{8}$ de produção, que se diferenciava de seu antecessor pelos aspectos de qualidade e a busca por padronizações visando aumento da produção (MAXIMIANO, 2015).

Novas e profundas mudanças continuaram a ocorrer nas décadas seguintes, com o surgimento dos primeiros estudos envolvendo aspectos sociais e humanos e seus impactos no mundo do trabalho (RODRIGUES, 2007). Esta fase ficou conhecida como Teoria das Relações Humanas ${ }^{9}$, capitaneada por psicólogos, filósofos e sociólogos voltados a investigar a relação entre motivação e produção, resultando num movimento de valorização do trabalhador por conta de sua importância na produtividade das organizações (MAXIMIANO, 2015).

Este movimento das relações humanas foi um marco na história da evolução das teorias organizacionais de tal forma que até hoje é considerada fonte de estudos sobre motivação humana, não só envolvendo a produtividade no mundo do trabalho como foi idealizada na época, mas num escopo mais amplo, de compreender as relações de trabalho com a qualidade de vida do trabalhador, tendo como um dos estudiosos, David McClelland, clássico pesquisador das relações sociais e motivacionais no mundo do trabalho. Os resultados de seus estudos possibilitaram a execução desse presente estudo, voltado para as características comportamentais empreendedoras (BARLACK, 2014; PERILLA TORO, 1998).

Seguindo a trajetória das teorias organizacionais e seus impactos no mundo do trabalho, surge novas teorias como a Teoria dos Sistemas e teoria do processo (basicamente defendendo inter-relação entre as partes e do processo enquanto um conjunto de partes interagentes que juntas formam um todo com objetivo único). O modernismo ligado à revolução centrada na mecanização das máquinas, na conquista do mundo material e na

\footnotetext{
${ }^{8}$ Sistema Toyota: sistema de produção desenvolvido no Japão em 1970. Prima pela valorização do operário participativo e ao contrário do modelo Fordista de produção, que pregava a metodologia de um operário por máquina, no modelo Toyota, vigora o operário polivalente e multifuncional, capaz de trabalhar com diversas máquinas simultaneamente. (MAXIMIANO, 2015).

${ }^{9}$ Teoria das relações humanas: estudos realizados por psicólogos, ancorado pelo teórico Elton Mayo que estudou por 5 anos, os aspectos de produção de dois grupos de trabalhadoras em uma empresa de dispositivos elétricos, relacionando a produtividade com questões de cunho social como relações sociais, estilos de liderança, motivação e ambiente. (CHIAVENATTO, 2006).
} 
produção de novos produtos surge para atender a uma nova classe de consumidores mais exigentes e mercado mais competitivo (STOCKMANNS, 2014).

Já para Zen e Fracasso (2008), os principais paradigmas das revoluções que impactaram no mundo do trabalho foram:

- Revolução industrial britânica, que dominou a economia mundial durante todo o século $\mathrm{XIX}$ e foi a base de observação para as primeiras teorias sobre o empreendedor. A Revolução Industrial teve um impacto significativo na economia e na organização social. A partir dela, surgiram diversos trabalhos da teoria econômica que buscavam explicar o processo de acumulação de riqueza e as primeiras definições para o termo empresário, relacionando-o ao termo empreendedor, com viés capitalista.

- Revolução industrial americana, o Fordismo, que surgiu nos Estados Unidos e difundiu o modelo de organização da produção em massa, dominante na maior parte do século XX período marcado pelo desenvolvimento das primeiras teorias da administração. No estudo das organizações industriais, o crescimento das empresas e o surgimento das sociedades por ações deslocaram a atenção do empresário-proprietário para questões como produtividade, estrutura organizacional e pessoal.

- Revolução tecnológica - paradigma da tecnologia da informação, centrado no movimento de globalização entre final do século XX e início do século XXI, período denominado pósmodernidade, decorrente dos avanços das tecnologias de informação e comunicação, que impactou no ambiente socioeconômico, em especial os processos produtivos e as relações de mercados. Os arranjos inter-organizacionais e as alianças estratégicas têm lugar de destaque nas pesquisas desse paradigma.

Dado o recorte histórico, consequências de um pós-modernismo, centrado na questão da mundialização das economias e da globalização de mercado, é que o neoliberalismo ${ }^{10}$, movimento centrado no livre comércio e na busca pela intervenção mínima do estado, tornou-se a base material das relações econômicas mundiais (BARLACK, 2014).

\footnotetext{
10 Neoliberalismo é uma ideologia socioeconômica iniciada na década de 1970, que preconiza a mínima intervenção do Estado na economia. Através de sua retirada do mercado, em tese se autorregularia e consequentemente regularia a ordem econômica (STOCKMANNS, 2014).
} 
Com a revolução tecnológica surge uma nova economia, baseada no conhecimento e na informação, na qual a inovação e a difusão tecnológica se tornaram elementos fundamentais ao desenvolvimento. Nesse contexto, se observa que os modelos contemporâneos são conduzidos por estratégias que permitem a flexibilização nos processos de produção e que buscam a inserção das empresas em redes formais e informais de negócios (ZEN e FRACASSO, 2008).

A globalização rompeu com o paradigma ${ }^{11}$ do capitalismo tradicional e impôs aos países periféricos a economia de mercado global sem restrições, a competição ilimitada e uma discussão sobre a minimização do Estado na área econômica e social. A globalização internacionalizou o capitalismo moderno, baseada nos avanços tecnológicos, nos meios de comunicação e transmissão de dados. Incute-se pela primeira vez a ideia de se estabelecer conexões entre mercado e educação profissional, buscando formas de fazer com que o setor educacional pudesse de alguma forma, contribuir para o desempenho das pessoas no mundo do trabalho, atendendo a essa nova formatação (BARLACK, 2014).

A ênfase nas redes de relacionamento, também conhecido como networking, e nas práticas de associativismo deu origem a dois tipos de trabalhadores modernos: o coletivo e o social, como resposta da sociedade às questões de demarcações sociais que foram sendo percebidas no paradigma atual e que serão melhor apresentados nas dimensões do empreendedorismo, mas à diante. (ZEN e FRACASSO, 2008). Corroborando com tais autores, Santos et.al (2014) complementa com um dado relevante sobre essas mudanças:

\footnotetext{
Uma pesquisa reveladora foi realizada pela Forbes em 1970 com as 500 pessoas mais ricas do mundo sobre quais seriam as principais habilidades que a escola deveria desenvolver e o resultado foi leitura, escrita e aritmética. Trinta anos depois, no ano de 2000, a mesma pesquisa foi feita novamente com as 500 pessoas mais ricas da época e obteve um resultado bem diferente, tendo como principais características o saber trabalhar em equipe, solucionar problemas e relacionamento interpessoal. Mesmo com esta mudança de paradigma, ainda hoje, ...estas são habilidades pouco trabalhadas na escola, sendo um problema não apenas brasileiro (SANTOS, 2014, p. 14, grifo nosso).
}

\footnotetext{
11 Thomas Kuhn (1998) considera paradigmas como realizações reconhecidas durante algum tempo por uma comunidade científica específica, proporcionando os fundamentos para sua prática posterior. Ou seja, um paradigma é substituído por outro quando não se adéqua mais ao contexto, quando já não mais se identifica com a realidade. Para Kuhn o desenvolvimento da ciência ocorre através de uma substituição de paradigmas, formando uma escala. Cada degrau representaria um novo paradigma, sendo galgado graças ao que foi desenvolvido na escala anterior (KUHN, 1998)
} 
Outros desafios também surgiram com tais evoluções. Libâneo e Oliveira (1998) ressaltam o paradoxo desta época que passou a existir a partir desse cenário globalizado. $\mathrm{A}$ evolução do capitalismo que possibilitou um aumento na velocidade do desenvolvimento tecnológico, também acentuou as desigualdades sociais decorrentes da concentração de riqueza. Essa preocupação está presente no campo da economia social - uma parte da economia que reconhece explicitamente a dimensão social pelos valores que the correspondem, mas, sobretudo, pelas regras que dão mais prioridade às pessoas do que ao capital, no que diz respeito às decisões, ao poder e aos resultados. Segundo os autores, o avanço tecnológico proporcionou ao ser humano a oportunidade de romper barreiras, sociais e geográficas.

No entanto, apesar da conjuntura favorável ao desenvolvimento econômico, a sociedade de modo geral também sofreu com esse cenário. Se por um lado, isso inegavelmente trouxe benefícios para a humanidade, ao mesmo tempo, também trouxe razoáveis perdas. "Nunca em uma sociedade se produziu tanto e, ao mesmo tempo, nunca houve tanta gente faminta, desempregada, esquecida, sem lugar para morar" (LIBÂNEO e OLIVEIRA, 1998, p. 44).

Os estágios das teorias organizacionais aqui brevemente sintetizadas permitem compreender sobre a figura do trabalhador e sua evolução como sujeito participativo do processo organizacional, ambiente este que serviu de pano de fundo para todas essas mudanças (BARLACK, 2014). Nessa perspectiva, sintetiza Rodrigues $(2007$, p. 13) ao afirmar que "compreender tal processo evolutivo implica em entender o desenvolvimento do homem organizacional e sua essência no contexto socioeconômico". Para o autor, as próprias organizações surgem também como resultado da ação de “indivíduos" em interação com o ambiente.

É nesta ação que surge o sujeito empreendedor e, na troca desse sujeito com o ambiente, o fenômeno empreendedorismo se manifesta. O empreendedorismo é, portanto, fundamentalmente, um fenômeno social, coletivo e interativo (VERGA e SILVA, 2014). 
A partir deste recorte teórico da teoria das organizações e sem a pretensão de esgotar o assunto, é possível refletir sobre as etapas ocorridas neste contexto, que impactaram o comportamento do trabalhador, como ilustra o esquema a seguir:

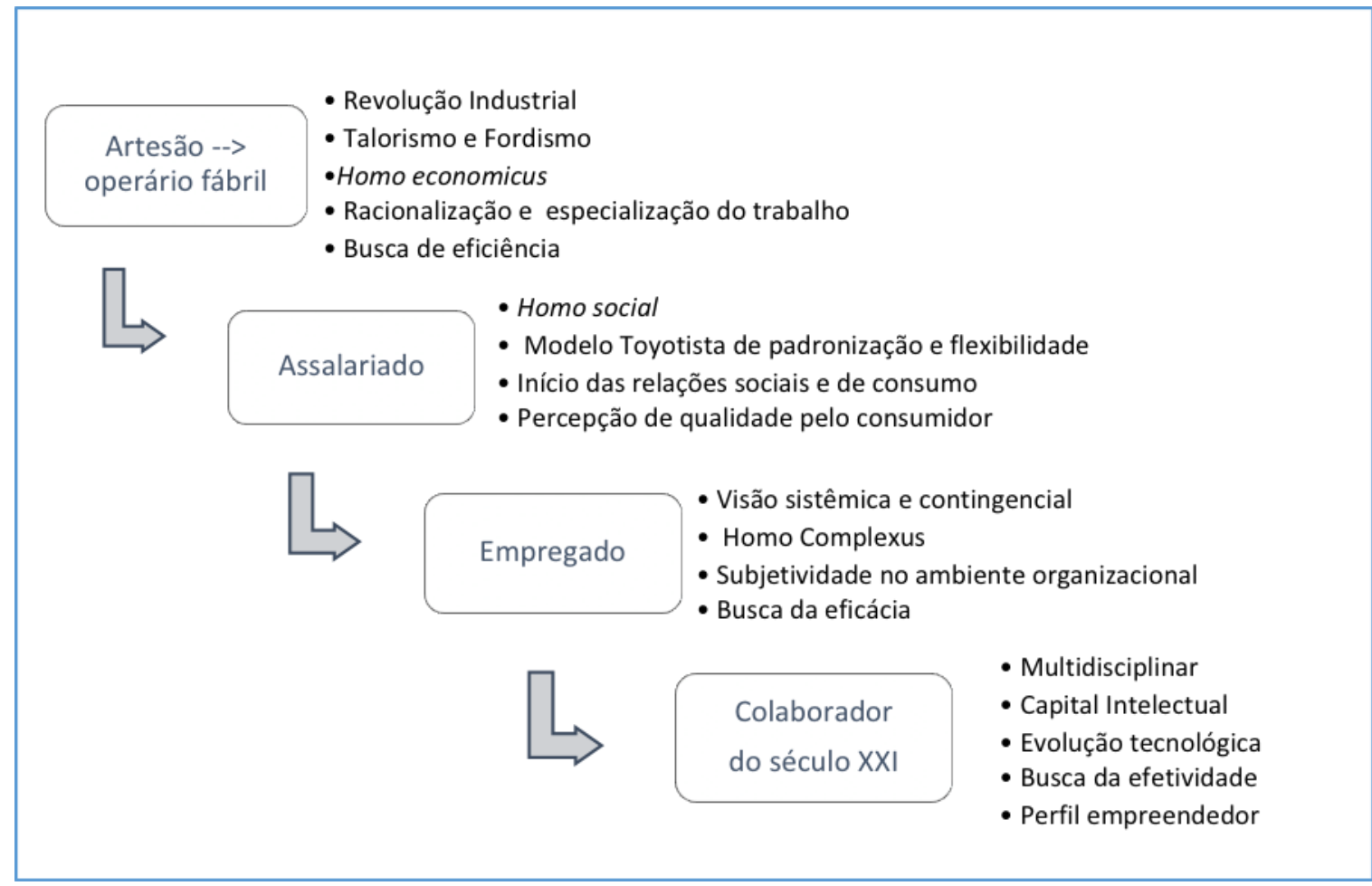

Gráfico 1: Fases históricas do papel do trabalhador no contexto de mercado Fonte: Autora

A inter-relação entre as teorias organizacionais --> evolução do papel do trabalhador --> crescimento e desenvolvimento econômico, e o surgimento do empreendedorismo são evidentes, pois são fenômenos ocorridos num mesmo contexto histórico envolvendo aspectos econômico, políticos e sociais e no protagonismo das pessoas em melhorar suas condições de vida, como afirma Rodrigues (2007, p. 07):

As origens dos campos de estudo desses fenômenos sob a ênfase do mundo do trabalho são muito próximas, inclusive bebendo das mesmas fontes. Aos poucos esses campos foram se distanciando, porém, as teorias organizacionais, os aspectos administrativos e o empreendedorismo estão historicamente relacionados em razão de ter como objeto de estudo, também, o trabalhador... o conjunto de interseção desses campos de estudo, fruto do caráter interdisciplinar do empreendedorismo, envolve a organização e sua dinâmica, o empreendedor e sua ação na impulsão de organizações, e a ação da organização sobre o sujeito empreendedor. 
Zen e Fracasso (2008) complementam esta ideia ao afirmar que essas passagens históricas influenciaram o fenômeno do empreendedorismo. Para os autores, o empreendedor é fruto desse processo evolutivo e refere-se a um termo dinâmico e multifacetado, influenciado por revoluções sociais, econômicas e tecnológicas. Desse modo, a ação empreendedora está fortemente relacionada ao contexto social e tecnológico no qual o empreendedor se insere. Alguns eventos foram essenciais para a construção do empreendedor que conhecemos hoje.

Segundo Dolabela (2009), todos esses desafios da subsistência humana, do mundo do trabalho, da necessidade formação humana permanente, o emprego (sendo esse uma relação de dependência) e o know-how (conteúdo adquirido pelo homem que o transforma em experiência), que constituíram o paradigma das relações de trabalho nos últimos séculos, são substituídos por um outro modelo - o da capacidade de gerar novos conhecimentos (expertises) e identificar oportunidades (inovação), em uma relação de interdependência (autonomia relativa), sob a forma empreendedora de trabalhar.

Nota-se que a estruturação do fenômeno empreendedorismo enquanto ciência, vem avançando significantemente nas últimas décadas, mas ainda assim é relativamente recente, comparando com as tradicionais teorias organizacionais, das quais se originou (ROCHA e FREITAS, 2014; SCHMIDT e BOHNENBERGER, 2019). As teorias organizacionais, por sua maturidade e contribuições para a evolução do homem no mundo do trabalho podem contribuir sobremaneira na construção desse processo de consolidação dos estudos sobre empreendedorismo, enquanto disciplina autônoma (STOCKMANNS, 2014).

Buscando compreender, não apenas aspectos contextuais, mas também aspectos epistemológicos do tema, faz-se necessária uma abordagem conceitual do processo de surgimento do empreendedorismo.

\subsection{EMPREENDEDORISMO: Conceitos e Definições}

A definição precisa do termo empreendedorismo, assim como seus estudos, é uma tarefa considerada complexa por muitos pesquisadores, em razão das inúmeras referências e conceitos dedicados ao termo (HISRICH, 2004; FERNANDES, 2014, SOUZA et.al, 2017; 
VIEIRA e MELATTI, 2011; KRÜGER, 2016; BARON e SHANE, 2013). Estudiosos de várias áreas e apresentados ao longo deste capítulo do trabalho já lançaram mão de suas definições, seja no campo da administração, da psicologia, da economia, da pedagogia, da sociologia, entre outras. Daí a dificuldade de unificá-las na busca de um conceito único que represente todas as definições já apresentadas pela literatura, até porque cada uma delas pôde dar sua parcela de contribuição para o processo de enriquecimento do tema. Apesar disso, acredita-se ainda ser importante a continuidade dessas reflexões tendo em vista as mudanças conjunturais que tendem a afetar o universo do empreendedorismo (COAN, 2011).

O primeiro uso do termo empreendedorismo, segundo Hisrich (2004) e Filion (1999), é atribuído a Marco Pólo numa tentativa de estabelecer uma rota comercial para o oriente, sendo um dos primeiros europeus a percorrer o "caminho da seda" para a China no século XIII. Como empreendedor, Marco Pólo firmou um contrato com um mercador possuidor de recursos monetários (hoje conhecido como capitalista) para vender suas mercadorias. Entrementes, o contrato da época oferecia um empréstimo para o comerciante aventureiro a uma taxa de 22,5\%, incluindo seguro. Quando este era bem-sucedido em seu propósito, e completava a viagem, os lucros eram divididos, cabendo ao capitalista a maior parte (até $75 \%)$, enquanto o comerciante aventureiro ficava com os $25 \%$ restantes. O capitalista da época era alguém que assumia riscos de forma passiva enquanto o aventureiro empreendedor assumia papel ativo, correndo todos os riscos físicos e emocionais inerentes ao trabalho.

Para Filion (1999), o termo empreender, ou imprehendere, tem origem do latim medieval, antes do século XV, e significa "tentar empresa laboriosa e difícil", ou ainda, "pôr em execução". Segundo o autor, a vasta literatura sobre o assunto não apresenta uma unanimidade de critérios para definição do conceito de empreendedorismo, nem tão pouco sobre uma única origem. $\mathrm{O}$ autor buscou a conceituação do termo ao longo do tempo e pôde constatar que seu significado foi se transformando de acordo com sua época, passando por vários significados até chegar ao que é conhecido atualmente pela literatura.

Outra vertente traz a ideia da palavra "empreendedor" originada no termo francês entrepreneur, que, literalmente traduzido, significa "aquele que está entre" ou "intermediário". Exemplo disso remete ao período da Idade Média, em que o empreendedor 
assinava um contrato com uma pessoa de recursos (o atual capitalista de risco) para vender suas mercadorias. Enquanto o capitalista assumia riscos passivamente, o intermediário assumia o papel ativo do negócio, tendo que suportar seus riscos físicos e emocionais. Foi apenas no final do século XII e início do século XIII que o termo foi usado para se referir à pessoa que criava e conduzia projetos ou empreendimentos. O entrepreneur era uma pessoa que identificava uma oportunidade de negócio e assumia seu risco, decidindo processar e revender matéria-prima. Dessa maneira, o risco apareceu nas atividades empreendedoras do século XIII (DRUCKER, 2016).

Somente no final do século XVII e início do século XVIII, a palavra adquiriu seu significado atual, com os estudos de Cantillon, em 1775, e aprimorada posteriormente por Jean Baptiste Say entre 1815 e 1839, que descreveram seu conceito de forma geral como uma 'pessoa que criava e conduzia projetos'.

Por volta de 1800, Say considerou o termo Entrepeneur, um dos fatores de produção ao lado da terra, do trabalho e do capital. Para Say, o empreendedor é definido como alguém que combina e organiza os fatores para viabilizar a produção. Cabem a ele as funções de gerenciamento e organização de recursos, associando assim, o empreendedor com a gestão. Say também foi o primeiro a definir as fronteiras sobre o que é ser empreendedor, dentro do entendimento moderno do termo, e o primeiro a delinear a diferença entre empreendedor e capitalista.

A visão de Say sobre o empreendedor é repleta de contribuições de diversas visões de sua época. Por ser um dos pioneiros, Jean-Baptiste Say é considerado um dos pensadores clássicos do empreendedorismo, fazendo com que suas ideias sejam ponto de partida no início do estudo. Cantillon e Say influenciaram toda a teoria sobre o empreendedor até os dias atuais. Como Say foi o primeiro estabelecer os alicerces desse campo de estudo, ele é considerado o pai do empreendedorismo (DORNELAS, 2014).

Além da fundamentação similar, outro traço comum entre as ideias de Cantillon e Say, reconhecidos como autores basilares do empreendedorismo, é que ambos consideravam os empreendedores como pessoas com capacidade de assumir riscos, visto que investiam seus recursos próprios, sempre na expectativa do lucro. Assim, compravam seus produtos por um determinado valor e depois revendiam. Deriva desse fato a 
compreensão do empreendedor como aquele que aproveita as oportunidades na perspectiva de ganhar mais do que investiu, porém, tem que correr os riscos inerentes a esse jogo (HISRICH, 2004).

Segundo Coan (2012), os conceitos de empresário, capitalista, investidor, operário foram trabalhados por Say com uma conceituação própria, e o empreendedor era o empresário industrial, aquele que é capaz de colocar a teoria na prática. Considerava que empreender capitais, na perspectiva da acumulação, era muito salutar e a ninguém deveria amedrontar uma vez que o próprio curso da natureza tenderia a reparti-los, promovendo crescimento de um país.

\footnotetext{
Árduo defensor do pensamento liberal, Jean-Baptiste Say se entusiasmava com o progresso econômico trazido pela revolução industrial e por ver o Estado monárquico, preocupado em tributar e gerar moedas, ruir por meio de grandes convulsões, abrindo espaços a um futuro melhor. A marcha do pensamento liberal em curso, da livre iniciativa de pessoas e nações, da concorrência, dava-lhe esperanças (COAN, 2012, pg. 04).
}

Um dos seguidores dos estudos sobre o conceito de empreendedorismo de Say, foi Joseph Shumpeter, que na década de 60 lançou como objetivo transmitir o universo do empreendedorismo descrito por Say, tornando-se seu discípulo (FILLION, 1999).

No Brasil, as obras de Schumpeter são as referências sobre empreendedorismo, considerado um dos autores modernos de maior expressão no contexto da teoria do empreendedorismo no mundo. Foi Schumpeter quem redefiniu o papel do empreendedor (que perdurava desde os teóricos clássicos da economia) e introduziu a função de criar mudanças na alocação de recursos como própria do empreendedor. Suas obras foram publicadas no início do século XX e hoje são referência para os estudiosos desse tema (BARON e CHANE, 2013).

Schumpeter destaca o papel do empreendedor como "motor da atividade econômica" e sua função de romper com a ordem econômica pré-estabelecida, sendo o primeiro a associar o termo à inovação e discutir a importância dos empreendedores para o desenvolvimento econômico e social das nações (FILION, 1999; DORNELAS, 2014, FERNANDES, 2014). 
Muitos estudos têm sido realizados na tentativa de melhorar a compreensão sobre o tema, por ser considerado como força econômica de um país, representando sua riqueza e seu potencial de geração de empregos (MURARO e VERRUCK, 2012), o que torna o tema empreendedorismo, segundo Vieira, Melatti e Ribeiro (2011), em processo de expansão para quase todas as disciplinas das Ciências Humanas. Chiavenato (2006) compila esta discussão com o seguinte conceito: o empreendedor é a pessoa que inicia e/ou opera um negócio para realizar uma ideia ou projeto pessoal, assumindo riscos e responsabilidades e inovando continuamente. Para o autor, o empreendedorismo está ligado a qualquer oportunidade vista por alguém de transformação e inovação que trará bens a si mesmo, a sua comunidade ou a toda sociedade, que não necessariamente financeiros.

Peter Drucker (2016) já estudava sobre a ascensão do termo nos Estados Unidos e atribuiu a ele o crescimento econômico entre as décadas de 50 e 60.0 autor enfatiza que o que chamavam de "tecnologia" impulsionadora deste crescimento econômico não era uma atribuição voltada à tecnologia como a conhecemos, mas sim, à "administração empreendedora".

Outra contribuição importante de Drucker (2016), e que merece destaque neste trabalho, refere-se à sua sinalização de que ações empreendedoras podem ser não apenas no aspecto comercial (que se associa a negócio), mas também como em serviços de saúde, de educação ou projetos sociais, embora ainda associem o termo "empresa" quando se depara com o termo empreendedorismo, como se esses outros serviços, chamados de não comerciais, não necessitassem de ações empreendedoras para serem bem-sucedidos.

Filion (1999) destaca uma definição clássica e atemporal sobre o termo empreendedorismo, por classificar de forma bastante abrangente o termo e poder representar as discussões de estudiosos do tema. Nesta definição, Filion expressa as características do empreendedor, sendo,

... uma pessoa criativa, marcada pela capacidade de estabelecer e atingir objetivos e que mantém alto nível de consciência do ambiente em que vive, usando-a para detectar oportunidades de negócios. Um empreendedor que continua a aprender a respeito de possíveis oportunidades de negócios e a tomar decisões moderadamente arriscadas que objetiva a inovação, continuará a desempenhar um papel empreendedor (FILION, 1999, p. 19). 
Tal definição é resultado de uma compilação de seus estudos, embasada na análise de conceitos desde o século XII, em que foram identificados termos importantes e que auxiliaram na construção da definição apresentada:

- Criatividade: vista não somente no surgimento da ideia como também na criação de todos os objetivos e passos para desenvolver a ideia;

- Objetivos: que guiarão suas atitudes, ou seja, têm a capacidade não só de estabelecer como de alcançar os objetivos traçados em prol da ideia;

- Oportunidades: que aparece diretamente ligada ao conhecimento que o empreendedor tem do ambiente em que vive. Além disso, não apenas identifica as oportunidades, como está sempre em alerta, conhecendo continuamente sobre o ambiente, e sua maneira de agir;

- Riscos: diferente do que se pensa sobre o risco que correm, os empreendedores não jogam roleta russa, ou seja, não se arriscam sem antes pensar nos riscos que correm. As decisões são baseadas em riscos previamente calculados;

- Inovação: sendo inovação diferente de invenção. A invenção está ligada a criação de um novo dispositivo, conceito ou serviço, que pode vir a ser útil. Inovação é a capacidade de transformar a invenção em sucesso, ou seja, implementar a nova ideia (FILION, 1999).

Dolabela (2008) complementa com a ideia de que o termo "empreendedorismo" corresponde a uma grande área de abrangência para a criação de empresas. Ainda para o autor, o empreendedor é aquele que tem a habilidade de criar e construir algo a partir do nada, sendo um indivíduo altamente criativo, encontrando energia pessoal para iniciar e construir uma empresa ou organização, fazendo mais do que simplesmente assistir, analisar ou descrever, utiliza os recursos disponíveis de forma criativa, transformando o ambiente social e econômico no qual vive. O empreendedor assume riscos, porém faz todo o possível para colocar do seu lado as vantagens, e assim reduzir as possibilidades de fracasso.

Outras definições sobre o termo empreendedorismo são compiladas na obra de Souza e Guimarães (2006), organizadas no quadro a seguir e objetiva ilustrar a ideia da pluralidade de termos e definições que a literatura nos mostra em relação ao tema: 


\begin{tabular}{|c|c|}
\hline Deakins e Freel (1996) & O termo empreendedor traduz ação de quem se sobressai na sociedade. \\
\hline Adam Smith (1937) & $\begin{array}{l}\text { Empreendedor é aquele tido como um proprietário capitalista, ou, } \\
\text { fornecedor de capital, ao mesmo tempo, um administrador que se interpõe } \\
\text { entre o trabalhador e o consumidor. }\end{array}$ \\
\hline Timmons (1985) & $\begin{array}{l}\text { O empreendedor é alguém capaz de identificar, agarrar e aproveitar } \\
\text { oportunidade, buscando e gerenciando recursos para transformar a } \\
\text { oportunidade em negócio de sucesso. }\end{array}$ \\
\hline Filion (1991) & O empreendedor imagina, desenvolve e realiza visões. \\
\hline Drucker (2016) & $\begin{array}{l}\text { A essência do empreendedor é transformar ideias inovadoras em ações } \\
\text { lucrativas por perceber as mudanças como sendo oportunidades de } \\
\text { negócios. }\end{array}$ \\
\hline Dolabela (1999) & $\begin{array}{l}\text { O empreendedor é aquele que sabe como transformar uma ideia em uma } \\
\text { realidade lucrativa. Sabe combinar visão e ação. }\end{array}$ \\
\hline Melo e Fróes (2002) & $\begin{array}{l}\text { Empreendedorismo é um processo dinâmico pelos quais os indivíduos } \\
\text { identificam ideias e oportunidades de negócio e atuam desenvolvendo-as, } \\
\text { transformando-as em empreendimentos privados ou sociais. }\end{array}$ \\
\hline Low e Macmillan (1988) & $\begin{array}{l}\text { Empreendedorismo trata-se de um processo pelo qual indivíduos iniciam e } \\
\text { desenvolvem novos negócios }\end{array}$ \\
\hline Begley e Boyd (1997) & $\begin{array}{l}\text { Empreendedorismo relaciona-se tanto com a criação de novos negócios } \\
\text { quanto com a inovação promovida dentro de empresas já estabelecidas. E } \\
\text { tido, portanto, como um complexo fenômeno envolvendo o } \\
\text { empreendedor, a empresa e o ambiente no qual o fenômeno ocorre. }\end{array}$ \\
\hline Brockhaus (1982) & $\begin{array}{l}\text { Empreendedorismo compreende necessidade de realização, propensão ao } \\
\text { risco, criatividade, visão, alta motivação, postura estratégica e } \\
\text { autoconfiança. }\end{array}$ \\
\hline Carland et.al (1998) & $\begin{array}{l}\text { Empreendedorismo é o resultado tangível ou intangível de uma pessoa } \\
\text { com habilidades criativas, interligadas as experiências de vida, } \\
\text { oportunidades e capacidade individuais, sendo inerente no seu exercício a } \\
\text { variável risco, tanto na vida pessoal como na carreira do empreendedor. }\end{array}$ \\
\hline Motta (1998) & $\begin{array}{l}\text { Empreender não é uma condição passiva, mas produto de participação, } \\
\text { envolvimento, comunicação, cooperação, negociação, iniciativa e } \\
\text { responsabilidade. O verdadeiro empreendedor é essencialmente um } \\
\text { indivíduo capaz de investir tempo e energia no futuro de sua organização e } \\
\text { principalmente, no de seu pessoal. }\end{array}$ \\
\hline
\end{tabular}

Quadro 8: Síntese de definições sobre o termo Empreendedorismo

Fonte: Souza e Guimarães (2006)

Pode-se perceber com as definições apresentadas neste apanhado feito por Souza e Guimarães (2006), que alguns termos são mais citados, dando-nos uma noção do viés de pensamentos sobre o tema. Para Pessoa (2008), termos como propensão ao risco, necessidade de realização e criatividade são usados repetidamente nos conceitos 
apresentados pela literatura e apresentados a seguir, para contribuir com a compreensão do tema.

\begin{tabular}{|c|c|c|c|c|c|c|c|c|c|c|c|c|c|c|c|c|}
\hline \multirow[b]{2}{*}{ Características } & \multicolumn{16}{|c|}{ Autores } \\
\hline & 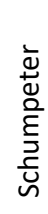 & 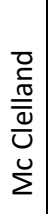 & $\frac{\bar{d}}{\frac{0}{2}}$ & $\frac{\text { 은 }}{\frac{\bar{z}}{4}}$ & $\begin{array}{l}\frac{0}{0} \\
\frac{0}{0} \\
0 \\
\text { ㅇ }\end{array}$ & 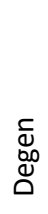 & 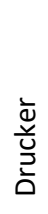 & $\begin{array}{l}\frac{\pi}{\pi} \\
\frac{\tilde{\sigma}}{\widetilde{\sigma}}\end{array}$ & $\begin{array}{l}\stackrel{0}{\stackrel{0}{*}} \\
\frac{5}{2}\end{array}$ & 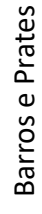 & 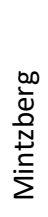 & 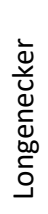 & 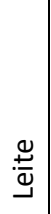 & 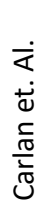 & 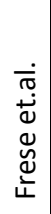 & 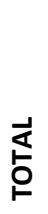 \\
\hline Busca por oportunidades & $\mathrm{x}$ & $\mathrm{x}$ & & $\mathrm{x}$ & $\mathrm{x}$ & $\mathrm{x}$ & $\mathrm{x}$ & & $\mathrm{x}$ & & $\mathrm{x}$ & $\mathrm{x}$ & $\mathrm{x}$ & & & 11 \\
\hline Conhecimento de mercado & & & & & & $\mathrm{x}$ & $\mathrm{x}$ & $\mathrm{x}$ & & & & & $x$ & & & 5 \\
\hline Conhecimento de produto & & & & & & $\mathrm{x}$ & $\mathrm{x}$ & $\mathrm{x}$ & & & & & $x$ & & & 5 \\
\hline Correr riscos & $\mathrm{x}$ & $\mathrm{x}$ & & $\mathrm{x}$ & $\mathrm{x}$ & $\mathrm{x}$ & $\mathrm{x}$ & & & & $\mathrm{x}$ & & $\mathrm{x}$ & $x$ & & 10 \\
\hline Criatividade & & $\mathrm{x}$ & & $\mathrm{x}$ & & $\mathrm{x}$ & & $\mathrm{x}$ & $\mathrm{x}$ & $\mathrm{x}$ & & & $x$ & $x$ & & 9 \\
\hline Iniciativa & $\mathrm{x}$ & $\mathrm{x}$ & & $\mathrm{x}$ & & & & & $\mathrm{x}$ & & & & $x$ & & $x$ & 6 \\
\hline Inovação & $\mathrm{x}$ & $\mathrm{x}$ & $\mathrm{x}$ & $\mathrm{x}$ & $\mathrm{x}$ & $\mathrm{x}$ & $\mathrm{x}$ & $\mathrm{x}$ & $\mathrm{x}$ & $x$ & $x$ & $\mathrm{x}$ & $x$ & $\mathrm{x}$ & $\mathrm{x}$ & 16 \\
\hline Liderança & $\mathrm{x}$ & $\mathrm{x}$ & $\mathrm{x}$ & $\mathrm{x}$ & $\mathrm{x}$ & & $\mathrm{x}$ & & & & $\mathrm{x}$ & & & & & 7 \\
\hline Necessidade de realização & $\mathrm{x}$ & $\mathrm{x}$ & & & & & & & & & $\mathrm{x}$ & & & $x$ & $\mathrm{x}$ & 5 \\
\hline Proatividade & $x$ & $\mathrm{x}$ & & $\mathrm{x}$ & & & & & & & & & & $x$ & $\mathrm{x}$ & 5 \\
\hline Visão & & & & $x$ & & & & & $\mathrm{x}$ & & $\mathrm{x}$ & & $\mathrm{x}$ & & $x$ & 5 \\
\hline
\end{tabular}

Quadro 9: Síntese de termos mais evidenciados nas definições sobre Empreendedorismo Fonte: Adaptado de Pessoa (2008)

Pode-se a partir deste compilado, propor uma definição, que se assemelha à definição de Pessoa (2008):

O conceito de empreendedorismo não pode ser entendido apenas, como um padrão de comportamento de uma pessoa. O empreendedorismo é um processo complexo e multifacetado que reconhece as variáveis sociais (mobilidade social, cultural e de sociedade), econômicas (incentivos de mercado, políticas públicas, capital de risco) e psicológicas (comportamental, motivacional) como influenciadoras do ato de empreender (PESSOA, 2008, pg. 71).

Nota-se, portanto, que o termo empreendedorismo, além de vasto, rico e extenso, apresenta também uma tipologia que foi se ampliando com o passar do tempo e dos contextos sociais e econômicos. Considerando a diversidade de interpretações sobre a figura 
do empreendedor, apresentadas por estudiosos das mais variadas áreas, como economistas, sociólogos, psicólogos, especialistas de ciências do comportamento ou ciências de gestão de negócios, o termo ganhou subdivisões quanto as suas dimensões, cada qual dando ênfase as características que consideram importantes e, ou, que foram agregadoras no momento em que estiveram pautando algum estudo na época.

\subsection{Dimensões do Empreendedorismo}

Os conceitos contemporâneos de empreendedorismo se desenvolveram a partir das definições clássicas já apresentadas. Porém, aquelas que mencionam o empreendedorismo exclusivamente como a criação de empresas não são atualmente as mais bem aceitas, pois o empreendedorismo atualmente, passou a englobar muito mais do que o mundo do negócio (KRUGER, 2019).

\section{-> Empreendedorismo na dimensão econômica}

A primeira concepção do termo empreendedor foi usada para referir-se aos "homens de negócio", sendo, portanto, relacionado unicamente ao empresário capitalista, preocupado com os riscos e incertezas do processo de acumular riquezas na prática de compra e venda de mercadorias que resultasse na obtenção de lucro, suportando o jogo do mercado, correndo o risco de ganhar ou perder, como defendiam Cantillon e Say, autores basilares do empreendedorismo (COAN, 2011). Ambos consideravam os empreendedores como pessoas que corriam riscos, visto que investiam seus próprios recursos sempre na perspectiva de ganharem mais. Compravam matéria-prima por um determinado preço, transformavam-na em produtos para depois revender.

Deriva desse fato a compreensão do empreendedor como aquele que aproveita as oportunidades na perspectiva de ganhar mais do que investiu, porém, tem que correr os riscos inerentes a esse jogo. Esses autores formularam suas ideias entre os fins do século XVII e início do século XIX no início do desenvolvimento da sociedade capitalista. Por ser entendido como fenômeno associado à economia, o empreendedorismo foi pesquisado e posto em prática apenas por cursos voltados à área de negócios que buscavam identificar 
elementos inerentes aos agentes econômicos e destacar seu papel na formulação de processos inovadores em gestão voltados para o mundo dos negócios.

A abordagem econômica e capitalista, portanto, se manteve como motivação para as primeiras definições, subsidiando os primeiros estudos sobre o tema. Para Filion (1999), tal visão econômica era uma interpretação da forma com que as empresas geravam lucros e para isso, necessitavam de pessoas com visão de negócios para alavancá-los. A relação do empreendedorismo com fatores econômicos e criação de negócios economicamente rentáveis desperta interesse de estudos no tema devido à sua influência no desenvolvimento econômico e social das regiões, em uma relação constante do empreendedorismo com a economia, numa época marcada pelo capitalismo (FILLION, 1999).

De acordo com Filion (1999), essa corrente é defendida por Cantillon, Schumpeter e Say, sendo que, para os dois primeiros, os empreendedores podiam ser vistos como pessoas que corriam riscos. Say distingue empreendedores e capitalistas, bem como os lucros de cada um deles e, com isso, começa a associar os empreendedores à inovação, considerando-os agentes de mudança. Porém, conforme registra Filion (1999), foi Schumpeter quem realmente lançou o campo do empreendedorismo, associando-o, claramente, à inovação e mostrando, em sua obra, a importância dos empreendedores na explicação do desenvolvimento econômico (PESSOA, 2008).

Apesar de uma forte influência no campo do empreendedorismo, a visão dos economistas é de que o empreendedorismo é uma função e que segundo Filion (1999, p. 5) vários tentam teorizar sobre o tema, mas "não existe uma teoria econômica sobre o empreendedor que reúna um consenso, nem um modelo econômico que explique o desenvolvimento a partir da função empreendedora, pois esta é dificilmente quantificável”.

As críticas a respeito da visão econômica como sendo a única forma de descrever o fenômeno do empreendedorismo ganha força com estudos de comportamentalistas que se contrapuseram ao conceito de que o homem era uma mera espécie de engrenagem na dinâmica econômica de um país 


\section{-> Empreendedorismo na dimensão comportamental}

A dimensão comportamental é a mais rica em termos de conteúdo. Apesar de ter sido a segunda dimensão apresentada pela literatura, considerando a cronologia dos estudos do tema, percebe-se claramente que ainda é considerada como basilar nos estudos sobre empreendedorismo, sobretudo quando os estudos focam as habilidades empreendedoras e como tais habilidades podem ser desenvolvidas no sujeito (KAUR e BAINS, 2013).

Em meados do século $X X$, o empreendedor passou a ser alvo de estudos de novos campos do saber como psicólogos, sociólogos, psicanalistas, administradores, que iniciaram pesquisados buscando entender a importância do comportamento empreendedor dos indivíduos. Segundo Filion (1999), Weber, com sua obra "A Ética Protestante e o Espírito do Capitalismo" foi um dos primeiros autores a pesquisar a temática, entre as décadas de 1940 e 1950, ao buscar identificar um sistema de valores das pessoas empreendedoras, como elementos fundamentais para justificar seus comportamentos (WEBER, 2004). Weber descrevia o empreendedor como pessoas inovadoras e com liderança no ambiente organizacional, além de identificar aspectos e valores religiosos que influenciavam nos resultados econômicos das organizações e da sociedade (FONSECA e MUYLDER, 2010).

Para Drucker (2016), o empreendedor consegue se dedicar intensamente às atividades que se propõe a fazer, pois seu trabalho se confunde com prazer, algo implícito, motivado pelo desejo de se aprimorar. Para o autor isso ocorre, pois, o empreendedor tornase autônomo, levando seus sonhos, desejos e preferências em conta em tudo o que faz. Possui espírito empreendedor, não como traço de personalidade, mas de comportamento.

No entanto, foram os estudos de David McClelland que de fato, contribuíram para a criação da dimensão comportamental do empreendedor (FILION, 1999). McClelland (1961, p. 11), criou uma definição para explicar as ideias de Schumpeter conciliadas com sua vertente comportamental. McClelland (1987) defendia que Schumpeter via no empreendedor a motivação não meramente no lucro, mas também "no desejo de formar 
uma dinastia particular, a vontade de conquistar numa batalha competitiva e a alegria da criação". Em outras palavras, o empreendedor de Schumpeter não é um ser completamente racional orientado pelo lucro somente, pois fatores psicológicos e sociológicos como caráter inovador, liderança, criatividade, iniciativa, autoconfiança e necessidade de realização, também são responsáveis por colocar as forças econômicas em movimento e essa junção que produz o desenvolvimento.

Ainda segundo Fillion (1999), a vertente comportamental tomou corpo com estudos em busca do entendimento das motivações para o ato de empreender. É a partir desta busca e das publicações que se seguiram, que se pode desenhar o caminho para o ensino do empreendedorismo, como um conjunto de competências, e, portanto, comportamental, que tem em sua essência a formação do sujeito empreendedor, dotado de conhecimentos, habilidades e atitudes voltados ao perfil empreendedor.

Para Rocha e Bacchi (2010), a identificação de traços característicos de personalidade e comportamento empreendedores tem sido a linha de estudo adotada por pesquisadores como a tentativa de estabelecer parâmetros que se apresentam de forma constante em empreendedores a fim de se chegar a um perfil desse sujeito. Ainda segundo os autores, muitas pesquisas têm sido realizadas a partir da perspectiva que aborda a compreensão das características da pessoa empreendedora em função do processo de empreender. Este processo diz respeito às funções, atividades e atitudes associadas à percepção de oportunidades que levam à criação de novos negócios, que tratam de forma organizada a busca por essas oportunidades. Diversas características são encontradas na literatura demonstrando certa convergência na definição do perfil empreendedor (DOLABELA, 2008; DORNELAS, 2013; FILLION, 1999; ROCHA; BACCHI, 2010). O quadro a seguir apresenta uma compilação de características indicadas pelos respectivos autores como componentes comportamentais do perfil empreendedor.

\begin{tabular}{|c|l|l|}
\hline Autor & \multicolumn{2}{|c|}{ Características do perfil empreendedor } \\
\hline \multirow{5}{*}{ Dolabela (2008) } & 1. Perseverança & 9. Capacidade incomum de trabalho \\
& 2. Iniciativa & 10. Liderança \\
& 3. Criatividade & 11. Orientação para o futuro \\
& 4. Protagonismo & 12. Imaginação \\
& 5. Energia & 13. Proatividade \\
& 6. Rebeldia de padrões & 14. Tolerância a riscos moderados \\
& 7. Capacidade de diferenciar-se & 15. Alta tolerância a ambiguidade e \\
8. Comprometimento & incerteza. \\
\hline
\end{tabular}




\begin{tabular}{|c|c|c|}
\hline Dornelas (2014) & $\begin{array}{l}\text { 1. Visionários } \\
\text { 2. Sabem tomar decisões } \\
\text { 3. Agregam valor ao que fazem } \\
\text { 4. Explora o máximo as oportunidades } \\
\text { 5. Determinados e dinâmicos } \\
\text { 6. Dedicados } \\
\text { 7. Otimistas } \\
\text { 8. Independentes }\end{array}$ & $\begin{array}{l}\text { 9. Geram riqueza } \\
\text { 10. Líderes e formadores de opinião } \\
\text { 11. Bem relacionados } \\
\text { 12. Organizados } \\
\text { 13. Planejadores } \\
\text { 14. Abertos ao conhecimento } \\
\text { 15. Assumem riscos calculados } \\
\text { 16. Criam valor para a sociedade }\end{array}$ \\
\hline Rocha; Bacchi (2010) & $\begin{array}{l}\text { 1. Eficaz } \\
\text { 2. Assume riscos calculados } \\
\text { 3. Planejador } \\
\text { 4. Detecta oportunidades }\end{array}$ & $\begin{array}{l}\text { 5. Persistente } \\
\text { 6. Sociável } \\
\text { 7. Inovador } \\
\text { 8. Líder }\end{array}$ \\
\hline
\end{tabular}

Quadro 10: Matriz de características do empreendedor

FONTE: Dolabela (2008); Dornelas (2014); Rocha; Bacchi (2010).

Aspecto complementar para a compreensão da dimensão comportamental do empreendedorismo está ligado ao ambiente em que ele se processa, vinculando-se às mais diversas atividades que demandam de iniciativas pessoais, como a busca por inovação, poder de comunicação e informação e as tecnologias que possibilitam novas ideias e novos modelos de gestão (SALIM e SILVA, 2010). O levantamento das características deste perfil empreendedor está associado ao fato de se criar uma referência para o desenvolvimento de processos que contribuam para a formação de empreendedores, utilizando tais características como premissas pedagógicas, quebrando o paradigma antigo que diz que o perfil empreendedor era nato, ou seja, a pessoa nascia com determinadas características e portanto, estava predestinada ao sucesso e pessoas que não possuíam tais características eram desencorajadas a empreender (DORNELAS, 2014). O estudo comportamental do empreendedorismo já aponta para uma perspectiva de formação e desenvolvimento das características necessárias ao empreendedor (KAUR e BAINS, 2013).

Na medida em que alguns elementos são vistos com mais frequência, passam a ser considerados como características associadas ao comportamento empreendedor, sem que sejam observadas em todos eles (DORNELAS, 2014):

1. conjunto de comportamentos e hábitos que podem ser adquiridos, praticados e desenvolvidos.

2. clara atitude proativa de observação da realidade, que os leva a ter uma boa percepção das oportunidades. 
3. habilidade para capturar e avaliar oportunidades e, a partir de suas ideias, desenvolver planos para realizar seus objetivos.

4. habilidade para obter apoio de colaboradores e financiadores para seus empreendimentos

5. habituados a tomar decisões.

6. busca incessante para criar valor para a sociedade por meio de seus empreendimentos.

Em decorrência das contribuições sobre o empreendedorismo comportamental é possível identificar uma ramificação, que traz discussões sobre um aspecto que relaciona-se com o comportamento - a dimensão motivacional. Estudos do Instituto Brasileiro de Qualidade e Produtividade, vinculado ao SEBRAE, de abrangência mundial, enfocam fenômenos relacionados à produtividade. Segundo o IBQP, o empreendedorismo pode ser identificado de duas formas no que diz respeito à motivação, ou seja, as condições do ambiente em que o indivíduo vive que impulsionaram a atividade empreendedora. $\mathrm{O}$ empreendedorismo pode ocorrer por oportunidade ou por necessidade das pessoas ou grupos.

Os empreendedores por necessidade são aqueles que iniciam um empreendimento autônomo por não possuírem melhores opções de trabalho, abrindo um negócio a fim de gerar renda para si e suas famílias. Os empreendedores por oportunidade optam por iniciar um novo negócio mesmo quando possuem alternativas de emprego e renda, ou ainda, para manter ou aumentar sua renda pelo desejo de independência no trabalho. (FERNANDES, 2014, p. 20).

Para a autora, os países teriam que reduzir as taxas de empreendedorismo ocasionado por necessidade e aumentar o empreendedorismo motivado por oportunidade, uma vez que este último tende a proporcionar melhores condições sociais e econômicas para a sociedade. Filion (1999) também se refere a esses dois tipos de empreendedorismo como sendo voluntário e involuntário quando menciona o empreendedorismo por oportunidade e por necessidade respectivamente.

Fernandes (2014) afirma que a maioria dos estudiosos do empreendedorismo contentam-se com essa divisão feita pelo IBQP - empreendedorismo motivado por necessidade $X$ por oportunidade. Há, ainda, autores que classificam este movimento como sendo empreendedorismo inercial, ou empreendedorismo por sucessão. O 
empreendedorismo inercial é aquele geralmente representado pelas empresas que passam de pai para filho, ou seja, o ambiente é favorável para que isso aconteça, independente da capacidade empreendedora do herdeiro, que simplesmente assume o projeto que está em andamento, seja pelo grau de parentesco, ou mesmo por afinidade nas relações existentes.

Para Drucker (2016), os aspectos motivacionais para o empreendedorismo, elencados como sendo uma condição externa, podem também ocorrer por meio de fatores intrínsecos ao indivíduo. Para Dornelas (2014), as motivações que fazem com que uma pessoa seja um empreendedor, estão ligadas a múltiplos fatores, que podem ser internos ou externos, ou seja, as condições sociais, econômicas, ambientais, características pessoais, ou ainda, diversos destes influenciando juntos o empreendedor potencial.

Para Kaur e Bains (2013), os parâmetros comportamentais do empreendedor baseiase nos componentes voltados ao desenvolvimento de certas competências, como:

a) Competência em estratégia: refere-se a empreendedores com capacidade de desenvolver uma visão para seus negócios. Desenvolver visão e estratégia, planejar com antecedência, estabelecer metas e padrões;

b) Competência de compromisso: demonstra forte motivação para competir, capacidade de causar impacto e dedicação.

c) Competência conceitual: o empreendedor requer competência analítica quando confrontado para abordar situações complexas. Demonstra capacidade cognitiva para a tomada de decisão, habilidade de decidir, capacidade de analisar riscos, pensar analiticamente, ser inovador e criativo;

d) Competência da oportunidade: refere-se à capacidade reconhecer oportunidade, capacidade de capturar oportunidade, capacidade de identificar as necessidades dos mercados;

e) Competência em relacionamento: possui e utiliza boas habilidades interpessoais e de comunicação, capacidade de influenciar os outros e obter apoio e trabalhar em equipes seja liderando ou sendo liderado; 
f) Organização da competência: é a capacidade de dirigir, liderar, delegar, motivar, planejar e agendar trabalhos e desenvolver programa, coordenar, monitorar e organizar recursos internos e externos do negócio;

g) Competência de aprendizagem: a capacidade de direcionar e utilizar seus conhecimentos e adaptar-se a mudança de papéis;

h) Competência pessoal: competência pessoal refere-se a qualidades e habilidades pessoais que ajudam na construção pessoal e aumenta a eficácia individual na execução de tarefas desafiadoras. Identificar pontos fortes e fracos e combiná-los com oportunidade e ameaças;

i) Competência técnica: Inclui a capacidade de usar e adotar habilidades técnicas incluindo relevantes para os negócios. Envolve possuir conhecimento dos instrumentos e funcionamento de ferramentas, máquinas ou procedimentos de pesquisa bem como o domínio das tarefas ou o conteúdo do trabalho;

j) Competência em Responsabilidade Social: A competência de responsabilidade refere-se a atividades positivas que uma empresa realiza na sociedade em que opera, elevando o conceito empresarial perante a sociedade;

k) Competência de âmbito familiar: Preocupação com a família, ter consciência da importância da família na construção do profissional enquanto ser humano e social;

I) Competência ética: significa alta clareza ética e capacidade de compreender os resultados de suas ações e seus impactos, ter consciência moral.

Baseado neste viés comportamental, foram desenvolvidas pesquisas importantes concentradas em discutir a forma com que o empreendedorismo pode ser ensinado, condicionado, enfatizando que resultados da efetiva aprendizagem dependem de metodologias voltadas à formação do perfil empreendedor, dada sua capacidade de empreender, dentro de um contexto que traga condicionantes teórico-práticos voltados à sua formação, aos formatos e relações de trabalho, e aos desafios inerentes ao seu universo profissional (DOLABELA, 2009). 
Assim, para se compreender o fenômeno do empreendedorismo, é necessário que se conheça seu processo de formação, afim de identificar e, a partir disso, promover a melhor metodologia, voltada às especificidades do empreendedorismo dentro de sua área. $\mathrm{O}$ assunto será melhor trabalhado em breve.

\section{-> Empreendedorismo na dimensão Social}

Contemporâneo à dimensão comportamental, tem-se a dimensão do empreendedorismo social. As abordagens sociológicas argumentam que os indivíduos são impulsionados a tomar decisões em suas carreiras, limitadas pela experiência e expectativas em relação a um contexto social (LÉVESQUE, 2004). Contrapondo a lógica de acumulação de riqueza capitalista, os empreendedores sociais não criam uma riqueza para si, mas geram riqueza coletiva para a comunidade em seu entorno. Os aspectos sociais observados pelas pessoas, fazem com que ajam de acordo com o ambiente em que vivem, como, por exemplo, sua classe social e composição familiar, podem influenciar as decisões de empreender (PESSOA, 2008). Drucker (2016), conceitua,

\footnotetext{
A julgar que as oportunidades e o acesso aos direitos contemplados na Constituição brasileira na prática não são os mesmos para todos os cidadãos, surge uma nova categoria na sociedade: a do excluído social. Esse é o campo de atuação do empreendedorismo social, que, numa primeira análise, pode ser observado a partir da junção das expectativas não realizadas da atividade do empreendedorismo com a problemática do Terceiro Setor, particularmente em decorrência do desemprego (DRUCKER, 2016, p. 79).
}

Diversamente das iniciativas capitalistas, para as quais o poder e os lucros pertencem exclusivamente aos acionistas, as iniciativas da economia social se baseiam na associação de pessoas ou na ação de um indivíduo com capacidade de mobilizar uma grande diversidade de recursos (ZEN e FRACASSO, 2008).

Dornelas (2014) conceitua o empreendedor social como um profissional que visa proporcionar um mundo mais favorável às pessoas. É aquele que luta, não por causas próprias, mas por causas humanitárias no desejo de mudar o mundo, proporcionando oportunidades a quem é menos favorecido. O empreendedor social busca caminhos para desenvolver o ser humano naquilo que é seu por direito, no resgate de sua cidadania, não apenas por ser lei, mas na procura de dar dignidade aos sujeitos. Seu pensamento abrange 
o social e busca com suas ações transformar a realidade. Este também visa solucionar problemas sociais como desigualdade social, prostituição infantil, violência de qualquer natureza, criminalidade, ausência de atendimento médico básico, dentre outras mazelas que afetam milhares de pessoas. É visto, portanto, como agente de mudança para a sociedade, em especial a região em que vive.

Os empreendedores sociais, assim como os empreendedores capitalistas, segundo Pessoa (2008) buscam novas oportunidades e também se preocupam com a inovação. Embora possuam a capacidade de mobilizar recursos para transformar um projeto em realidade, se distinguem claramente por seu interesse pela justiça social.

O processo de empreendedorismo social exige principalmente o redesenho de relações entre comunidade, governo e setor privado, com base no modelo de parcerias. Os princípios comuns entre os empreendedores sociais envolvem: valorização e promoção da troca de experiências dos participantes; visão multidisciplinar; respeito às diferenças; compreensão das origens dos problemas sociais e políticas públicas; compromisso e difusão de valores como cidadania e humanismo; e adoção da postura de facilitador na construção conjunta do conhecimento (ITELVINO, et.al 2018).

O resultado final desejado é a promoção da qualidade de vida social, cultural, econômica e ambiental sob a ótica da sustentabilidade (BAGGIO e BAGGIO, 2014). Para os autores, o empreendedor social é um sonhador. Aquele com pretensão de mudar o mundo e se vê na responsabilidade de contribuir para esse feito. "O empreendedorismo social é um misto de ciência e arte, racionalidade e intuição, ideia e visão, sensibilidade social e pragmatismo responsável, utopia e realidade, inovação e praticidade. O empreendedor social subordina o econômico ao humano, o individual ao coletivo e carrega consigo um grande sonho de transformação da realidade atual" (BAGGIO e BAGGIO, 2014, p. 31).

Para Itelvino et.al (2018), o empreendedorismo social está ligado às necessidades da sociedade, em que a pessoa está inserida e pode ser desenvolvido por motivos de cunho filantrópico, como ações de empoderamento praticadas em comunidade, ou de cunho idealista, baseado na busca do bem-estar social comum. A identificação de oportunidades neste caso ocorre a partir de uma carência presente na sociedade, e o ganho está no sucesso dos empreendimentos que dão conta de suprir uma carência ou parte dela. 
Este tipo de empreendedor, segundo Lévesque (2004) difere dos demais em dois aspectos: não produz bens e serviços para comercializar e gerar lucro, mas para solucionar problemas sociais, e não é direcionado para mercados, mas para segmentos populacionais em situações de risco social (exclusão social, pobreza, miséria, risco de vida).

Como exemplo de empreendimentos sociais encontramos conteúdos voltados à luta contra as condições de educação e saúde como questões no âmbito das políticas públicas, segurança coletiva das comunidades periféricas, atividades voltadas à promoção da autonomia de grupos vulneráveis e até as organizações que abrigam pessoas sem-teto. Pessoa (2008), afirma que a opção profissional segue padrões ditados pela estrutura de oportunidades pelos quais os indivíduos estão expostos na educação e na oportunidade de emprego. Assim, os autores compreendem o empreendedor como um catalisador das oportunidades que Ihe são apresentadas. Estes, por sua vez, fazem um mapeamento dos requisitos e condições necessárias para seu objetivo de ação, e desenvolvem indicadores para medir os progressos e resultados, avaliando assim o desempenho da sua iniciativa de mudança.

Segundo Itelvino et.al (2018, p. 109), destaca-se também neste contexto,

... o fato de que os espaços de formação do empreendedor social não devem ser tratados de forma excludente, mas contemplar a integração dos conhecimentos, valores, competências e habilidades oriundos e adquiridos nos espaços de educação formal e não formal, possibilitando a transposição do sujeito de um estado de exclusão para o de cidadania. Portanto, é relevante o entendimento da atuação do empreendedor social como gerador de inovações sociais a partir da avaliação de seu processo de formação, incluindo a análise conjugada de seus espaços e contextos de aprendizagem, suas motivações sociais e trajetórias de liderança social.

Acrescenta-se a esse cenário, a importância do empreendedorismo social enquanto temática de política pública, que tem sido pauta recorrente de discussões em diferentes estratos da sociedade como proposta de melhoria da qualidade de vida das pessoas, contribuindo para a geração de desenvolvimento sustentável. Particularmente na área acadêmica, o trabalho de pesquisa a partir das narrativas de história de vida preenche uma lacuna no processo de formação de futuros empreendedores sociais, oferecendo um conjunto de atitudes a serem estimuladas pelas esferas educacionais e empresariais para o fomento de novos empreendimentos sociais (BAGGIO e BAGGIO, 2014). 
Para Dornelas (2014), o cerne do empreendedorismo social é a relação indissociável entre a realização pessoal/profissional e a possibilidade de melhorar as condições de vida do outro. Para tanto, busca-se criar organizações que preencham as lacunas sociais, anteriormente de responsabilidade do Estado. Buscando retorno financeiro, mesmo não sendo seu objetivo final, e com a aquisição de novos recursos, essas organizações compartilham a intenção de capacitar o cidadão. A inovação de suas ações é consequência da busca de metodologias que garantam ao ser humano dignidade por meio de soluções para os problemas sociais. Sua medida de sucesso é o impacto no social, dada sua possibilidade de ser agente de mudança, considerando que suas ideias e inovadoras metodologias podem ser divulgadas, aplicadas e multiplicadas em outros grupos de risco. Sua satisfação profissional está relacionada à melhoria da qualidade de vida das pessoas.

Os empreendedores sociais são inovadores sociais por excelência, motivados para transformar a sociedade e serem agentes dessa mudança, além disso, adotam uma missão para criar e sustentar o valor social, tornando-se multiplicadores dessas inovações. Sua motivação, enquanto promotor de mudança, está relacionada a inovações que resultem em transformação social com potencial de replicação e ampliação em outros contextos e regiões. Suas práticas inovadoras necessitam ser compartilhadas por todos os atores envolvidos. Isso demanda habilidades relacionais bem desenvolvidas, capacidade de comunicação e aplicação de processos de inovação, sendo esta sua grande contribuição, por promover a busca de novas formas de pensar, se relacionar e criar estruturas, padrões e conexões em diferentes dimensões que agreguem valor para a coletividade (PESSOA, 2008).

Ainda é a partir do empreendedor social, que também se encontra o empreendedorismo sustentável, ou o ecoempreendedor. Suas atividades podem envolver ações ambientais voltadas à melhoria da qualidade de vida de sua região tais como: recolhem materiais recicláveis para fábricas que os transformam em novos produtos; desenvolvem produtos feitos com materiais reciclados; transformam óleo usado de motor, que seria descartado de modo inapropriado, em lubrificantes ou reciclando em material de limpeza; reciclam os líquidos resfriados de aparelhos de ar condicionado quebrados ou desmontados; transformam embalagens plásticas de leite em um plástico, que não exige manutenção; usam jornais velhos para fazer forragens baratas e resistentes a bactérias, para animais de 
fazendas; transformam sedimentos e restos de alimentos em fertilizantes e compostagens (BAGGIO e BAGGIO, 2014).

Pessoa (2008) enfatiza que locais onde há instituições de fomento a pequenos negócios como, por exemplo, o SEBRAE, há um movimento mais presente de pessoas motivadas a empreender social e sustentavelmente, seja por razões pessoais, econômicas ou comportamentais, o ambiente em que o empreendedor está inserido pode influenciar favoravelmente no seu comportamento de empreender, baseado na cultura que é trabalhada.

Com suas ações, o empreendedor social muda o modo como as pessoas reagem às mazelas da vida, capacitando-as e oferecendo possibilidade de reinserção social, sendo a educação e a criação de novos espaços de experiência de vida participativa, fundamentais para essa mudança. Busca de forma ética e perfil de líder, mobilizar as pessoas e conscientizálas de seus direitos. Destaca-se também que o seu grande sonho, a transformação da realidade social, concretiza-se por meio de uma atitude crítica e de inconformismo diante da injustiça social.

\section{-> Empreendedorismo digital}

O empreendedor digital, também chamado de "e-empreendedor" e "webempreendedor", surge em virtude dos avanços nas tecnologias de informação e comunicação e seus impactos no ambiente socioeconômico em especial nos processos produtivos e nas relações de mercados, criando uma janela de oportunidades, de produtos e serviços baseados em inovações tecnológicas que preencham algumas necessidades das demandas atuais como: aproximação entre empresa $x$ cliente, melhora da interação entre as pessoas, agilidade da comunicação e na troca de informação e dados, segurança nas transações financeiras, e, facilidade para a vida das pessoas (OLIVEIRA et.al, 2019).

Esse paradigma é marcado pelo surgimento, nas últimas décadas do século $X X$, de uma nova economia baseada no conhecimento e na informação, na qual a inovação e a difusão tecnológica se tornaram elementos fundamentais ao desenvolvimento. Os atuais padrões de consumo e de consumidor e seu poder de negociação, interfere nas regras do jogo quando o assunto é competitividade (ZEN e FRACASSO, 2008). 
Atualmente o consumidor conhece seu poder de consumo e nível de exigência como régua para medir a qualidade dos serviços prestados pelas empresas. Pessoas buscam meios pelos quais possam realizar tarefas rotineiras como compras, leituras, pagamentos, entre outras, de forma rápida e segura sem precisar sair de casa. Esse perfil de consumidor implica num reposicionamento das empresas em termos de manutenção de mercado e isso está intimamente ligado à qualidade de vida das pessoas. Inovar neste sentido é questão de ordem. As ferramentas tecnológicas podem sobremaneira auxiliar as empresas a cumprir com este papel. Desta forma, o empreendedorismo digital busca a visualização de oportunidades de negócios, em que existe uma busca incessante por inovações, assumindo riscos calculados com a intenção de obter renda, reconhecimento e crescimento no mercado (LÉVY, 2010).

A internet ${ }^{12}$ é de longe, a inovação mais transformadora das últimas décadas e dela resultou num divisor de águas na forma com que nos relacionamos globalmente, seja nas relações comerciais, relações sociais, na educação, etc. Esta inovação surgiu na década de 1960 criada com objetivos bélicos para melhorar a comunicação entre militares e suas bases. No Brasil, a internet teve sua expansão na década de 1990, com investimentos do ministério das comunicações, ciência e tecnologia e do governo federal que revolucionou a forma com que as empresas passaram a se relacionar com seus clientes. Mudou também a forma como os consumidores passaram a se relacionar com as empresas. Essas relações ganharam o mundo pois romperam barreiras geográficas, proporcionando a ambos buscarem negociações além de seu território habitual (LÉVY, 2010).

Com a migração das empresas para a internet, a maneira de se fazer negócios mudou, levando os empreendedores a se adaptarem ao ambiente virtual, pois nesse espaço, indifere se uma empresa é pequena, média ou de grande porte, pois sua visibilidade é a mesma, gerando democratização nesse sentido. Uma empresa de pequeno porte pode se mostrar virtualmente, muito "maior" que uma grande empresa, de fato, em razão da forma com que se posiciona no ambiente virtual (OLIVEIRA et.al, 2019). Ainda segundo os autores:

\footnotetext{
12 Internet: rede computacional interconectada, também chamada de rede mundial de computadores- www, que são interligados por cabos ou sem fio (wireless), o que possibilita a interação entre pessoas do mundo todo de forma rápida e com custos baixos, disponibilizando por meio de endereços http um voluma de dados informacionais nunca antes visto (LÉVY, 2010).
} 
O comportamento dos consumidores mudou e fez com que as empresas também mudassem. Não basta mais somente vender, é necessário estabelecer um relacionamento com seu cliente, entender seu comportamento e utilizá-lo de maneira eficaz. Através da internet é possível realizar essas tarefas de maneira rápida e detalhada, conquistando assim um maior número de clientes e aumentando a possiblidade de xplica-los (OLIVEIRA et.al, 2019 p. 13).

Além dos aspectos relacionados diretamente ao perfil empreendedor digital, este pode aliar-se ao empreendedorismo social na busca por proporcionar a inclusão digital das classes sociais menos favorecidas, possibilitando que todas as pessoas sejam capazes de ter acesso à internet. Dessa forma, a vantagem do empreendedorismo digital para a sociedade é oferecer por meio da internet produtos e serviços com preços acessíveis, possibilitando que os indivíduos sejam inseridos na economia de forma igualitária.

\section{-> Empreendedorismo na dimensão Multidisciplinar}

A dimensão multidisciplinar do empreendedorismo advém das transformações que estão ocorrendo no cenário global da atualidade, que vem sendo desenhada a partir do século XX pela complexidade de uma sociedade em constantes e rápidas transformações, impactando no modelo de mercado e na figura do profissional empreendedor, que passa a viver sob o impacto de um processo de transição não só de seu contexto interno como externo (SOUZA e GUIMARÃES, 2006). Pode-se aferir a partir desta reflexão, que o empreendedorismo multidisciplinar é resultado de todas as dimensões que já foram apresentadas, tornando a multidisciplinar, uma coletânea de visões e a junção das características empreendedoras necessárias para o enfrentamento dos desafios atuais.

Nota-se neste contexto, que o campo do empreendedorismo expandiu-se por quase todas as ciências sociais, humanas, econômicas e tecnológicas, seguindo a tendência que vinha sendo trabalhada anteriormente (KAUR e BAINS, 2013).

O constructo empreendedor que se estuda hoje, dentro do contexto organizacional atual, está contido em muitos outros cenários de estudos, a exemplo da mudança organizacional, o que torna o termo empreendedorismo, ofuscado pelos conceitos clássicos dos estudos das organizações, porém, implícito de maneira muito enraizada no cotidiano do mundo do trabalho. Nessa perspectiva, muitos destes estudos, publicados sob a vertente organizacional, trazem em suas palavras-chave, o termo empreendedorismo (ZEN e 
FRACASSO, 2008). Alguns temas que atrelam o empreendedorismo como subárea são: incubadoras e sistemas de apoio às micro e pequenas empresas; as empresas de alta tecnologia; redes de cooperação; auto emprego; educação empreendedora; questões de gênero, minorias e grupos étnicos e o empreendedorismo.

E empreendedorismo, segundo esses estudos, está relacionado com todos estes fatores. O mercado de trabalho ou de negócios, demanda adaptação para enfrentar as múltiplas tarefas de formação, dada sobretudo pela tecnologia da informação num contexto caracterizado pela democratização das relações, revolução tecnológica e pela necessidade de estabelecer conexões com o universo do trabalho, mais conhecido como networking (KAUR e BAINS, 2013).

Pessoa (2008) apresenta uma síntese dos trabalhos de vários autores que estudaram sobre a visão multidisciplinar do empreendedorismo e que estão organizados a seguir:

\begin{tabular}{|c|c|}
\hline Descrição Multidisciplinar & Autor(es) \\
\hline $\begin{array}{l}\text { Trabalho de cunho epistemológico, procurando retratar a } \\
\text { racionalidade instrumental do campo dos conhecimentos do } \\
\text { empreendedorismo. }\end{array}$ & Béchard (1996) \\
\hline $\begin{array}{l}\text { Empreendedorismo como sendo o resultado da interação entre } \\
\text { inúmeras variáveis que se influenciam mutuamente como: processo; } \\
\text { o ambiente; os recursos e o contexto organizacional. }\end{array}$ & Morris et.al (2001). \\
\hline $\begin{array}{l}\text { Aponta a teoria do caos e do paradigma da complexidade na ação } \\
\text { empreendedora, afirmando que uma sociedade estritamente } \\
\text { determinista, seria apenas ordem, um universo sem devir, sem } \\
\text { inovação e sem criação. }\end{array}$ & Bygrave (1993) \\
\hline $\begin{array}{l}\text { Defendem a criação de um paradigma que ainda não atingiu } \\
\text { consenso referente a construção do termo na atualidade, tendo em } \\
\text { vista que é proveniente de praticamente todas as ciências humanas } \\
\text { e gerenciais. É a necessidade da criação de uma teoria que não se } \\
\text { limite apenas a uma abordagem unidimensional em função da } \\
\text { complexidade do campo. }\end{array}$ & $\begin{array}{l}\text { Déry e Toulose (1998) } \\
\text { Danjou (2002) }\end{array}$ \\
\hline $\begin{array}{l}\text { Empreendedorismo é um fenômeno psico-sócio-econômico- } \\
\text { culturais complexo, não podendo desta forma, ignorar os fatores que } \\
\text { influenciam neste complexo de saberes. }\end{array}$ & Verstraete (1999) \\
\hline $\begin{array}{l}\text { Capacidade de aproveitamento de oportunidades } \\
\text { independentemente das condições e recursos disponíveis. }\end{array}$ & Stevenson (2004) \\
\hline
\end{tabular}

Quadro 11: Estudos sobre o empreendedorismo na dimensão multidisciplinar Fonte: Pessoa (2008) 
Para Pietrovski et.al (2019), um perfil e empreendedor multidisciplinar passa a ser necessário para atender às exigências das mudanças nos estilos de vida da sociedade atual, para um estilo de vida mais colaborativo, em que as pessoas estão mais propensas aos aspectos de coletividade e de parcerias, à troca de ativos intangíveis como tempo, espaço, habilidades e dinheiro, dentre outras formas de colaboração emergentes, tais como os exemplos de modelos de trabalho do empreendedor multidisciplinar ou colaborativo, a seguir:

- Crowdsourcing: ferramenta de cocriação a partir da participação on-line;

- Crowdfunding: financiamento coletivo, a partir de redes de pessoas e/ou instituições que investem em projetos criativos, ou voltados ao engajamento colaborativo;

- Crowdlearning: ferramentas de aprendizado colaborativo, como sites para o aprendizado de idiomas, ambientes virtuais de práticas colaborativas;

- Couchsurfing: compartilhamento de hospedagem para pessoas que viajam a passeio ou a negócios; e

- Coworking: escritórios de trabalho coletivo.

Esse arranjo colaborativo, também é chamado de empreendedorismo coletivo, por duas razões: a necessidade de um funcionamento democrático para realizar plenamente seu potencial e, a constituição prévia de um grupo de pessoas para a criação de um empreendimento coletivo, sendo que tal agrupamento deve ocorrer antes de se constituir o próprio empreendimento, assim como a mobilização de recursos para operacionalização da iniciativa (ZEN e FRACASSO, 2008).

Este empreendedorismo compartilhado pode ser representado por formas de associativismo que vão desde a criação de entidades de representação política e sindical até ações como compra em comum, serviços pós-venda, prospecção e venda nos mercados externos, controle de qualidade e aval solidário. As empresas de pequeno porte possuem muitas dificuldades, que podem ser superadas por meio deste tipo de empreendedorismo (SCHIMIDT e DREHER, 2008). De acordo com Dolabela (2008, p. 105), "o sonho do empreendedor coletivo é promover o bem-estar da coletividade e cujo trabalho consiste em 
levar a comunidade a desenvolver sua capacidade de sonhar e de realizar seu sonho - pois a construção e a busca do sonho coletivo é tarefa de todos os integrantes de uma comunidade". Nota-se, portanto, caráter social, com o uso das tecnologias digitais, com visão de negócio e fortes características comportamentais como motivação para a mudança, tais como enfrentamento de desafios, iniciativa, busca por metas e a polivalência das redes de contato.

O viés multidisciplinar no papel do empreendedor, portanto, ancora-se em todas essas mudanças culturais, tecnológicas, econômicas e sociais e que demandam um perfil de profissional multi-visão. Para Zucatto e Silva (2014), a pergunta que se faz é: que tipo de produto este consumidor exigente e antenado quer? Que tipo de inovação o público espera das empresas? Quais impactos ambientais este projeto terá? Quais tecnologias tem disponíveis para oferecer um produto ou serviço diferenciado? São questões inerentes ao complexo universo mercadológico atual e que se torna pano de fundo para tais reflexões.

Contudo, percebe-se que, no campo de estudos sobre o empreendedorismo, há uma ausência de consenso a respeito do perfil ideal de empreendedor e das fronteiras dos paradigmas do empreendedorismo. Os economistas tendem a concordar que os empreendedores estão associados à inovação e são vistos como forças direcionadoras de desenvolvimento. Os comportamentalistas atribuem aos empreendedores características de criatividade, persistência, resiliência e liderança (SILVA, 2015).

Pietrovski et.al (2019) defendem o empreendedorismo social como sendo um avanço no tema por trazer à tona, questões de ordem social, ambiental e cultural, que demandam mudanças na forma de viver das pessoas. Tem-se ainda o empreendedorismo digital, que vincula aspectos da revolução tecnológica como sendo o viés de formação deste tipo de empreendedor voltado para as demandas que a tecnologia da informação impõe, de maneira ampla, a necessidade de expertise para seu sucesso. A dimensão multidisciplinar destaca que o campo do empreendedorismo deve ser abordado como um fenômeno psico-sócioeconômico-cultural, em função de sua complexidade.

Diante desta complexidade, dos vieses do empreendedorismo e dos desafios elencados para o papel do empreendedor, conclui-se que a visão multidisciplinar, como o 
próprio nome diz, vem agrupar as várias características empreendedoras, tendo este novo papel como um papel agregador, criada a partir das contribuições de cada visão.

Para este trabalho os elementos do empreendedorismo são retratados no seguinte esquema gráfico:

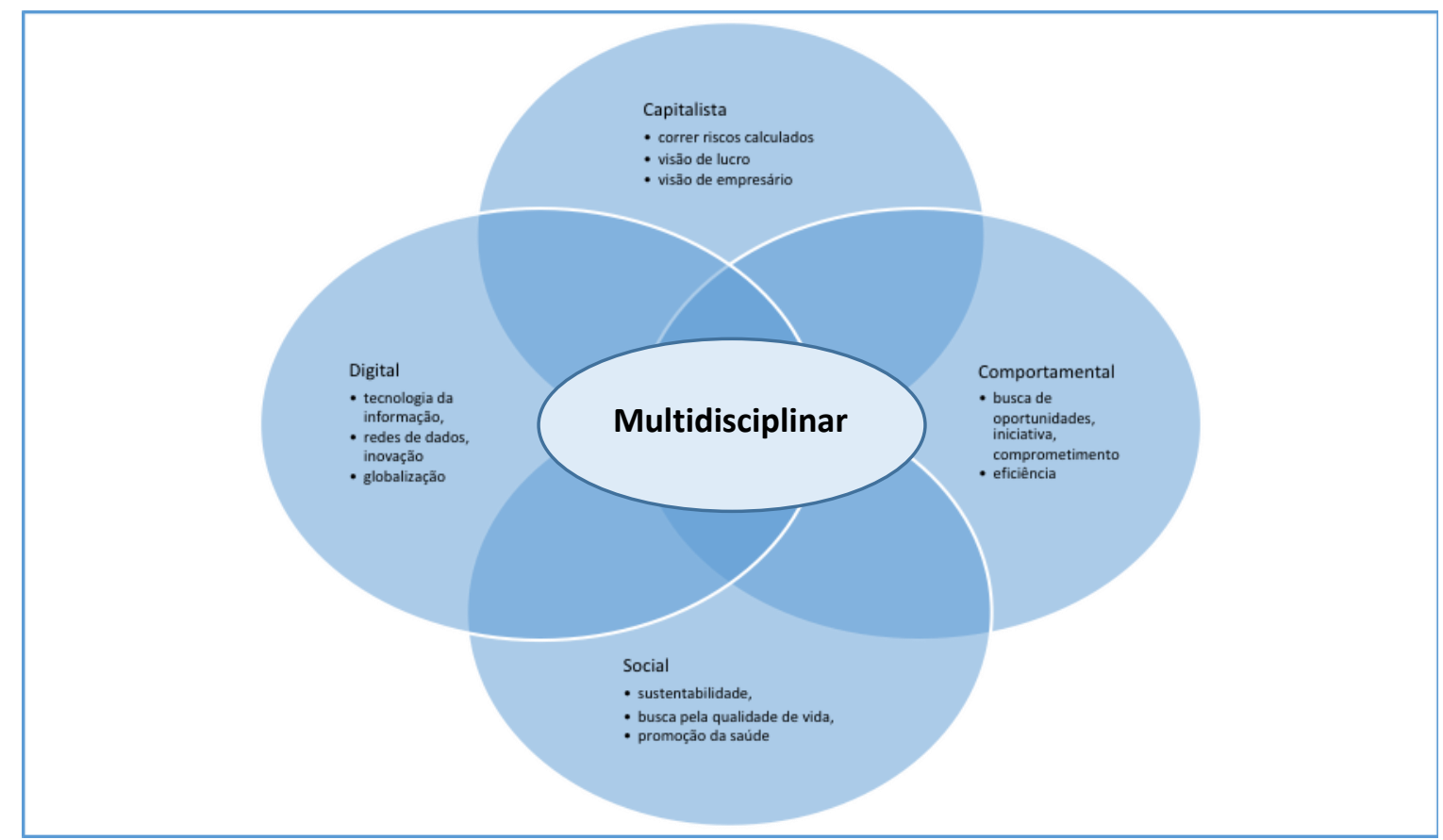

Gráfico 2: Empreendedorismo como multi-visão ou multidisciplinar

Fonte: Autora

O esquema acima traz a junção das visões do empreendedorismo que foi ganhando atributos diante das mudanças ocorridas no cenário mercadológico, influenciadas por mudanças das mais variadas áreas, como política, social, cultural e digital. Diante dessas mudanças o perfil empreendedor foi adaptando-se às conjunturas, agregando visões, se modernizando para atender os desafios que a atualidade apresenta.

\subsection{Considerações acerca dos conceitos sobre Empreendedorismo}

Cabe registrar que este trabalho não teve a pretensão de esgotar a busca de todos os autores que se propuseram a trazer conceitos sobre empreendedorismo haja visto o volume de trabalhos stricto-sensu, artigos científicos e publicações acerca das definições do tema. Observou-se que, quanto mais se lê e mais se pesquisa, mais materiais são descobertos e mais rico vai se tornando o processo de pesquisa. No entanto, espera-se que os conceitos 
trazidos tenham cumprido dois papéis: que sejam os mais fundamentalmente representativos, ou seja, de autores que não poderiam faltar num trabalho científico que discorra sobre o empreendedorismo e, que tenha conseguido atribuir ao tema o valor, a significância e a importância que esse assunto tem para o contexto organizacional atual.

Assim como os demais trabalhos, que contribuíram para o arcabouço aqui apresentado, cabe a este estudo, sugerir um conceito sobre empreendedorismo, que abarque os elementos históricos apresentados e ao mesmo tempo trace uma conexão com as ideias defendidas pelo estudioso David McClelland. Primeiro por corroborar com seus estudos e as contribuições que trouxe para o universo do empreendedorismo. Segundo por ser o autor dos trabalhos que culminou nas características comportamentais empreendedoras que ancora este trabalho, na realização da pesquisa de campo. A teoria de McClelland se sobressai dentre as demais pela amplitude de sua abordagem sendo considerada ainda hoje uma das teorias mais amplas, reconhecida mundialmente por sua atemporalidade dentre as teorias empreendedoras e comportamentais da motivação humana (KRÜGER, 2016). Em seus estudos, McClelland destaca o comportamento das pessoas com seu vínculo de trabalho, traz ainda as mudanças do século XX evidenciando os temas relacionados ao empreendedorismo, ao perfil e comportamento empreendedor, o que evidencia a importância de estudar e fomentar o empreendedorismo diante de sua importância para o desenvolvimento das nações (MCCLELLAND, 1961).

Diante das discussões dos principais autores sobre o tema e no sentido de também contribuir para os estudos sobre o tema, tem-se como definição, que o empreendedorismo hoje se resume na ciência que estuda os atributos inerentes ao profissional de sucesso e sua visão de mundo, possuidor de uma atitude proativa e ética, capaz de ler, interpretar e trabalhar as demandas e necessidades sociais e mercadológicas latentes, na incansável busca pelo aprimoramento de seu expertise, estar receptivo à novas oportunidades e crer que a inovação, a persistência e o comprometimento são as alavancas motivadoras desta engrenagem. 


\subsection{EMPREENDEDORISMO: Seu percurso no Brasil}

Historicamente, o Brasil é conhecido por sua capacidade de encontrar soluções inovadoras e seu potencial para enfrentar os desafios da economia, seja pelas dificuldades sociais, ou oportunidades naturais que o território brasileiro proporciona (SANTA RITA, et al, 2008).

Os estudos do tema no Brasil iniciam-se na década de 1980, ganhando adesão no ensino superior e alastrando-se para outros níveis de ensino após alguns anos. Em 1981 o tema empreendedorismo começa a ser ensinado pela Escola de Administração de Empresas da Fundação Getúlio Vargas em São Paulo-capital e em 1984 a Faculdade de Economia, Administração e Contabilidade da USP, também passa a oferecer a disciplina. Também em 1984, foi oferecido um curso de empreendedorismo pelo Departamento de Ciência da Computação da Universidade Federal do Rio Grande do SUL (UFRGS). Em 1989, a Fundação Getúlio Vargas criou o Centro Integrado de Gestão Empreendedora (CIAGE) com o objetivo de realizar estudos sobre o empreendedorismo. Em 1993, foi criada uma rede de ensino de empreendedorismo por meio do programa SOFTEX/CNPq (Associação para Promoção da Excelência do Software Brasileiro) com o desenvolvimento de uma metodologia de ensino de empreendedorismo e atingiu mais de 100 departamentos de ensino de informática em 23 estados brasileiros e no Distrito Federal (SOUZA et.al, 2004).

Em maio de 1992, a Universidade Federal de Santa Catarina - UFSC criou uma Escola de Novos Empreendedores - ENE com a missão de promover ações de intercâmbio com a sociedade que resultassem na criação, desenvolvimento e consolidação de uma cultura empreendedora. Em 1998, a ENE lançou o Programa de Empreendedorismo em Educação, direcionado ao ensino fundamental, reunindo profissionais e pesquisadores de múltiplas áreas de conhecimento, docentes e alunos do Curso de Pós-Graduação em Engenharia de Produção, tendo como foco o empreendedorismo para as crianças. Em 1999, foi criado na UFSC o Programa Engenheiro Empreendedor com o objetivo de oferecer cursos na área de empreendedorismo e de organizar concursos de planos de negócios para alunos das engenharias. A partir de então, houve expressivo crescimento do ensino do empreendedorismo em diversas universidades e cursos (FERNANDES, 2014). 
Para Fernandes (2014), este aumento no volume de pesquisas vem de encontro com o momento atual, de profundas mudanças profissionais, econômicas e tecnológicas, e no modo acelerado e dinâmico com que as elas ocorrem. A criatividade - principal pilar do empreendedorismo - é tida como diferencial na descoberta de novos insights, que mudem a forma de trabalhar, com melhor aproveitamento dos recursos e das pessoas. A razão desta popularidade está relacionada com o crescimento do número de criação de pequenos empreendimentos e sua permanência no mercado, buscando reduzir as taxas de mortalidade dessas empresas, que, têm recebido atenção de governo e de entidades de classe, num momento de grandes mudanças com o fenômeno da globalização e alto grau de competitividade de mercado (DORNELAS, 2014).

Para o autor, uma das consequências imediatas deste fenômeno da globalização foi o aumento do índice de desemprego, sobretudo nas metrópoles, onde se concentra um maior número de empresas. Estes trabalhadores, tendo ou não alguma experiência como empreendedores, tentariam recomeçar suas vidas, criando seus próprios negócios, tornando-se então empregadores e não mais empregados. A partir daí se veem desafiados a enfrentar um ambiente de competitividade, altas taxas de juros, falta de crédito e excesso de impostos, razões pelas quais, os índices de mortalidade dessas empresas aumentavam.

Essa junção de fatores motivou o aumento de estudiosos do assunto no país, com incremento significativo de pesquisas cientificas no meio acadêmico, aliada à criação de programas voltados à formação empreendedora, como o programa governamental Brasil Empreendedor em 1999, que tinha como meta formar mais de 1 milhão de empreendedores brasileiros para a elaboração de planos de negócios, um documento que traz o passo a passo das ações e estratégias para abrir seu próprio negócio (SEBRAE, 2017).

O empreendedorismo tem aliados importantes no país. O tema é estudado e acompanhado por instituições como SEBRAE - Serviço Brasileiro de apoio à micro e pequenas empresas, que fomenta, por meio de cursos, palestras e consultoria às empresas de pequeno porte, o desenvolvimento do empreendedorismo por seus dirigentes, fornecendo também periodicamente, estudos e levantamentos dos dados sobre empreendedorismo no país e auxiliando pesquisadores sobre o tema a se atualizarem (ZEN e FRACASSO, 2008). 
No Brasil especificamente, a preocupação com a criação de pequenas empresas duradouras e a necessidade da diminuição das altas taxas de mortalidade desses empreendimentos são os motivos para a popularidade do termo e suas pesquisas, que tem recebido especial atenção por parte do governo e de entidades de classe. Após várias tentativas de estabilização da economia e da imposição advinda do fenômeno da globalização, empresas brasileiras tiveram de procurar alternativas para aumentar a competitividade, reduzir os custos e manter-se no mercado (DORNELAS, 2013).

Dados publicados pelo SEBRAE apontam que os números de mortalidade dessas empresas brasileiras veem caindo nos últimos anos, no entanto, a continuidade de estudos sobre esse fenômeno são necessários tendo em vista que a maior parte dos negócios criados no Brasil ocorre por meio desses empreendimentos de pequeno porte, com gestores sem muita experiência, atuando de modo geral de forma empírica (SEBRAE, 2017). Tal cenário coloca o Brasil em posição de destaque no ranking do Global Entrepreneurship Monitor $\left(\mathrm{GEM}^{13}\right)$, programa de pesquisa de abrangência mundial e desenvolvido pelo SEBRAE e pelo Instituto Brasileiro de Qualidade e Produtividade (IBQP) fundado em 1999, conta atualmente com quase cem países no projeto que tem como finalidade aprofundar o conhecimento sobre as questões relacionadas ao empreendedorismo e é tido como o maior estudo em andamento sobre o empreendedorismo no mundo.

Tal pesquisa objetiva acompanhar a evolução, o crescimento e as mudanças que ocorrem no mundo, com o empreendedorismo. Com base no último relatório, foram 60 países participantes ( $83 \%$ do PIB mundial). No Brasil, a pesquisa foi realizada nos meses de setembro - outubro - novembro de 2016 e contou com 2.000 entrevistas, com uma população de 18 a 64 anos, além de 74 entrevistas com especialistas buscando levantar fatores limitantes e favoráveis ao tema. Segundo o GEM, quatro em cada dez brasileiros tiraram seus projetos do papel em 2016, o que elevou os números de empreendedores no país para 39,3\% (SEBRAE/SP). No entanto, "tirar um negócio do papel" requer perfil empreendedor, que consiste em buscar a inovação, conhecer o panorama mercadológico no qual se está inserindo e objetividade para elaborar e seguir um projeto com cronograma e

${ }^{13}$ O GEM é o maior projeto de pesquisa internacional que pretende medir e analisar a orientação dos indivíduos de um país para a atividade empresarial e que condições favorecem o aumento e desenvolvimento do Empreendedorismo. É o maior estudo anual sobre a dinâmica empresarial no mundo (BOTTONI, et.al, 2019). 
etapas bem definidos. Aqueles que possuem e desenvolvem tais características conseguem se destacar dos potenciais concorrentes (DORNELAS, 2013).

Todos os anos, em média, cerca de 600 mil novos negócios são iniciados no país. Atualmente, há aproximadamente 1,5 milhão de microempreendedores individuais no Brasil, como mostra a figura a seguir, que traz também as taxas de empreendedorismo inicial (TEA), taxa de empreendedores estabelecidos (TEE) comparado à taxa total de empreendedores (TTE):

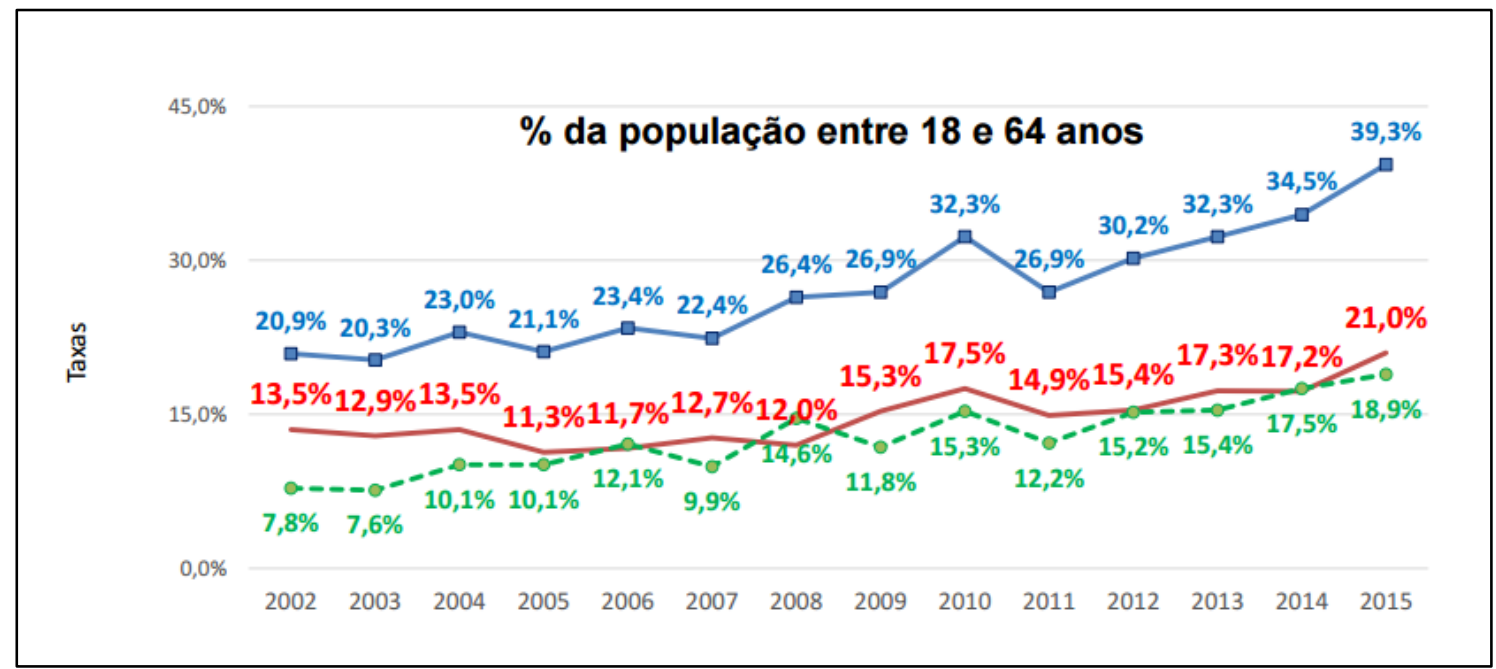

Gráfico 3: Evolução das taxas TEA, TEE e TTE - no Brasil - Instituto GEM (2017) Fonte: GEM 2017 (SEBRAE)

Esse crescimento das taxas de empreendedores iniciais segundo Bottoni, et.al (2019), está diretamente relacionado aos aspectos econômicos que afetam o desemprego e coloca muitas pessoas na condição de empreendedorismo por necessidade que compreende a busca por uma oportunidade que supra suas necessidades tendo em vista a falta de outra ocupação. Segundo os autores, no Brasil essa tipologia é a mais evidente na atualidade.

Comparando com outros países, em 2017 um índice no Brasil foi de 18,9\%, a frente da China que obteve 3,1\%, Estados Unidos com 7,3\%, Reino Unido obteve 5,3\% e Canadá com $8,9 \%$, segundo SEBRAE/SP. Já em relação às economias em desenvolvimento, a taxa brasileira é superior a África do Sul com 3,4\% e Chile com 8,2\% (SEBRAE, 2017). 


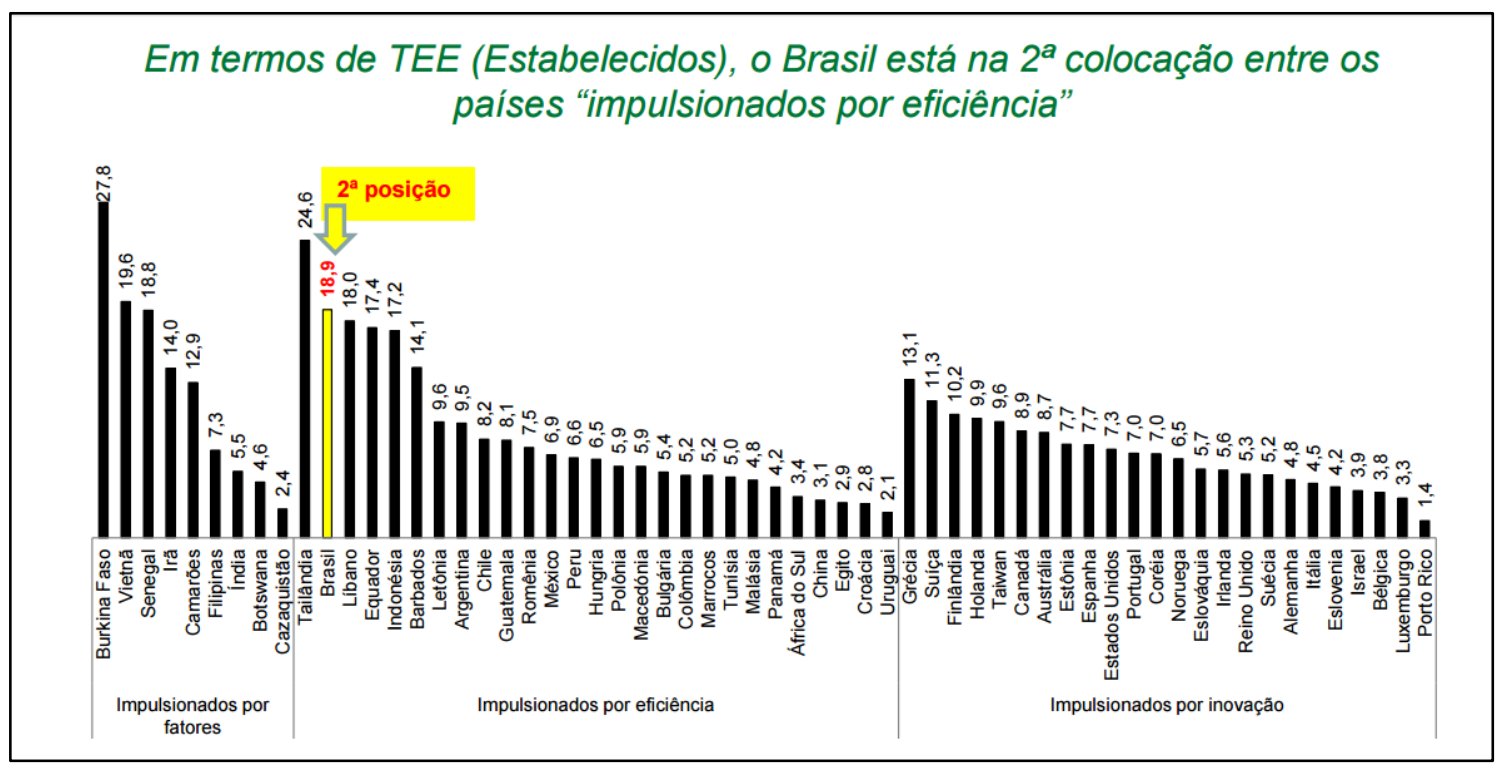

Gráfico 4: Comparação das taxas internacionais - Instituto GEM (2017)

Fonte: GEM 2017 (SEBRAE)

Dentre outros dados que merecem destaque, está o fato de os entrevistadores responderem que querem ter seu próprio negócio - 34\% a fazer carreira numa empresa, com $23 \%$, como mostra o quadro:

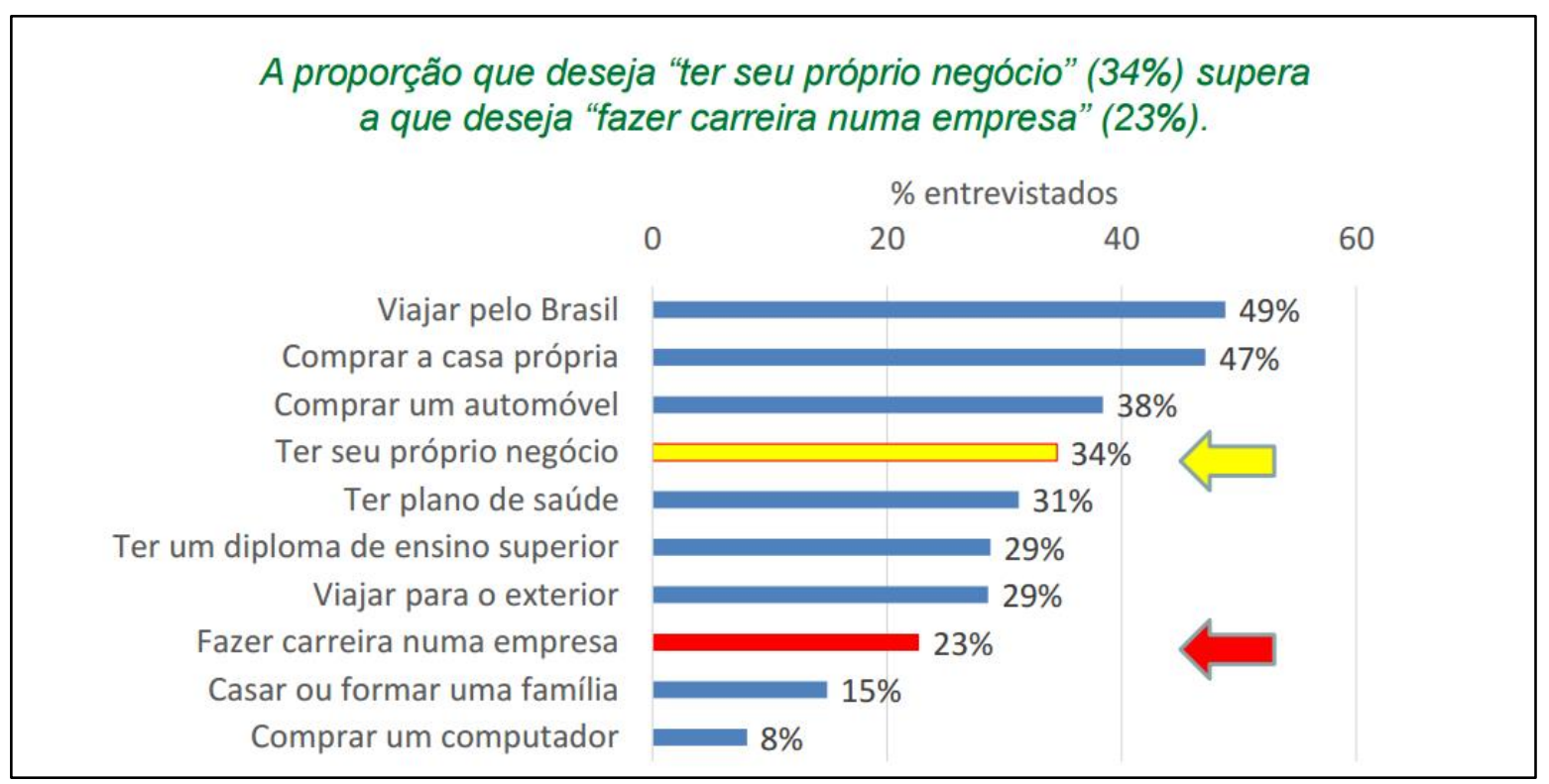

Gráfico 5: Comparação das respostas dos brasileiros - Instituto GEM Brasil (2017) Fonte: GEM 2017 (SEBRAE)

Entretanto, para obter sucesso nesta empreitada de abrir seu próprio negócio - três fatores são considerados fundamentais e precisam ser fomentados constantemente: auxílio governamental, oportunidade de investimento e formação educacional (DORNELAS, 2013): 
- Auxílio Governamental: a criação de legislações simplificadas, como o caso do Simples e do MEI, são bons exemplos de determinações que aumentam a fluidez da criação de empresas. Os impostos reduzidos também são considerados uma ação governamental e favorecem o empreendedorismo no país. Com taxas reduzidas, o empreendedor se sente mais estimulado a investir, renovando o ciclo do reabastecimento de novos negócios.

- Oportunidade de Investimento: este alicerce está pautado no próprio empreendedor. O profissional precisa ter ou desenvolver um perfil empreendedor, que consiste em ter a iniciativa de assumir riscos para transformar seus projetos em realidade. Um empreendedor é aquele que consegue perceber o que pode e o que precisa ser melhorado em sua volta, transformando a realidade de uma população, oferecendo serviços que atendam a uma determinada necessidade observada.

- Formação educacional: a educação está no centro de qualquer desenvolvimento econômico de uma nação, que precisa ser crítica, reflexiva e pluralista, não só na graduação como também na educação de base, favorecendo aos futuros profissionais, uma base sólida da visão de um negócio (DORNELAS, 2013).

Sobre este terceiro fator, o empreendedorismo tem recebido crescente atenção da comunidade acadêmica, o que resulta em trabalhos e estudos que tentam eexplicá-lo. Uma das causas para isso talvez seja o fato de que os empreendedores, mesmo quando não possuem habilidades técnicas e gerenciais, representam a ponte entre o desenvolvimento de inovações e o crescimento econômico. É justamente essa ligação entre habilidade e capacidade empreendedora e desenvolvimento econômico/social que faz com que o estudo do empreendedorismo esteja cada vez mais atrelado ao estudo da formação empreendedora (HENRIQUE E CUNHA, 2006; SOUZA e GUIMARÃES, 2006; SOUZA et.al, 2004).

Essa necessidade de formar profissionais qualificados para o novo cenário produtivo, ou seja, de preparar um indivíduo capaz de superar os desafios impostos por este contexto de transformações complexas, gerar riqueza e transformações sociais, em meio a um cenário de crises e competição fez surgir ações na esfera das políticas públicas para a educação, colocando as instituições de ensino diante de novos desafios para os quais até então não estavam preparadas (DORNELAS, 2013). Dessa forma, a educação, que sempre exerceu papel 
importante no desenvolvimento econômico e social das civilizações, é convocada novamente pelos economistas a formar trabalhadores com perfil para gerar produtividade (SILVA, 2015).

A dificuldade da inserção no mercado de trabalho tem sido outra questão importante para as Instituições de Ensino Superior (IES) em formar profissionais que não dependam, somente, de vínculo empregatício para se sustentar e aplicar seus conhecimentos. A esse fato, tem se associado à dificuldade da sobrevivência profissional em uma sociedade de elevada competitividade (SOUZA e GUIMARÃES, 2006).

Nessa linha, Dolabela (2008) compreende que em uma economia movida, essencialmente, pelo capitalismo, representado por grandes empresas tende a direcionar as IES para a formação de profissionais para exercerem papel de empregados. Para o autor, este modelo tem sido esgotado na proporção que a alteração das relações de trabalho e de produção tem deslocado seu eixo para as pequenas empresas, impulsionando a sociedade a formar empregadores em maior número que empregados.

É nesse ponto, segundo Muraro e Verruck (2012), que a universidade deve surgir como agente promotor do conhecimento, estimulando o desenvolvimento do perfil empreendedor nos jovens estudantes, que assumirão o papel de profissionais nesse cenário. A Educação Empreendedora segundo Dornelas (2013), coloca-se como uma possível proposta para formar indivíduos com perfil empreendedor, capazes de enfrentar as dificuldades e ultrapassar os grandes desafios da economia, de um mundo globalizado e competitivo.

Para Ramalho, et al. (2016, pg.99):

Formar empreendedores apresenta-se com grande tônica nesta última década, tarefa que vem se tornando cada vez mais significativa e necessária, considerandose o decréscimo dos postos de trabalho no mundo inteiro. Sua relevância parece ainda maior ao se focar a necessidade de conciliar, cada vez mais, o mundo do trabalho com o prazer da realização humana, ou seja, pensar em saúde e qualidade de vida.

Com isso, o ensino de empreendedorismo vem crescendo a cada ano, deixando para trás sua fase embrionária e se consolidando como conteúdo obrigatório nos principais centros de graduação e pós-graduação, nos mais diversos segmentos de formação (HENRIQUE E CUNHA, 2006), atendendo a uma demanda de mercado que se amplia a cada 
dia em busca por profissionais autônomos, inovadores, tomadores de decisão e dispostos a arriscar, para além do convencional. Tal perfil não é exclusividade de uma profissão ou de outra, mas de todas, nas mais diversas áreas e segmentos.

\subsection{Considerações acerca do processo evolutivo do empreendedorismo}

Nota-se por meio dessa análise histórica que atitudes empreendedoras e concepções de empreendedorismo são antigas, vastas e abrangentes, dentro do contexto ao qual foram sendo lançadas, dando várias interpretações para o tema. Os contextos sociais, econômicos e de mercado foram modificando os pensamentos sobre o tema, introduzindo características peculiares de cada época e fazendo com que o assunto fosse ganhando roupagens que vinham a convergir com as situações. Os contextos influenciavam e eram influenciados pelo caráter empreendedor dos homens de negócio. Os conceitos foram se sobrepondo e se fundindo, adquirindo novos formatos (MURARO e VERRUCK, 2012; HENRIQUE e CUNHA, 2006; DORNELAS, 2014).

Faz-se mister salientar que, apesar das nuances entre alguns autores, caminha-se para um entendimento cada vez mais conciso, ou seja, uma visão mais democrática do que o empreendedorismo é atualmente. A sociedade de modo geral começa a conceber a importância do empreendedorismo para o desenvolvimento econômico das nações. Hoje é difícil pensar em uma sociedade sem a figura do empreendedor. São os empreendedores que estão rompendo barreiras comerciais e culturais, encurtando distâncias, globalizando e renovando os conceitos econômicos, criando novas relações de trabalho e novos empregos, quebrando paradigmas e gerando riquezas para a sociedade (KRÜGER, 2019). 


\begin{abstract}
"Minha presença no mundo não é a de quem a ele se adapta, mas a de quem nele se insere. É a posição de quem luta para não ser apenas objeto, mas também sujeito da história".

Paulo Freire
\end{abstract}

O ensino do empreendedorismo vem sendo foco de debates e estudos por todos os continentes e sua propagação ocorre com o objetivo de se criar ferramentas e estratégias de enfrentamento de questões como o desemprego e a pobreza, diante de um novo contexto produtivo, caracterizado como uma crescente ordem de competitividade e globalmente tecnológico (SILVA, 2015; CUNHA et.al, 2009).

As publicações sobre tal concepção são heterogêneas, composta por conteúdos confluentes e divergentes sobre o uso de diversas práticas pedagógicas. A abundância de opções pedagógicas é fruto da peculiaridade da educação empreendedora, a qual necessita de métodos de ensino que desenvolvam as habilidades e técnicas empreendedoras nos estudantes através de experiências práticas durante a aprendizagem (SILVA e PENA, 2017). Ao pesquisar sobre ensino do empreendedorismo, educação empreendedora e cultura empreendedora, nota-se que a variedade é grande, não só em termos de quantidade, quantidade como também de abordagens, práticas pedagógicas, filosofias de ensino, que colocam personagens como aluno, professor, dirigentes de ensino, políticas educacionais e a sociedade como protagonistas no processo (LUCENA e CENTURIÓN, 2011).

Segundo Coan (2011), o discurso da necessidade de se educar para o empreendedorismo ganhou relevo nos anos de 1990, quando várias propostas foram apresentadas para combater os problemas decorrentes desse desemprego que atingiu sobremaneira os jovens. Segundo Coan (2011, p. 217):

O diploma não é mais garantia de colocação profissional. Junto a ele deve haver também habilidades e competências empreendedoras. Os concluintes do Ensino Médio, profissional ou universitário saem em busca do primeiro emprego, mas nessa empreitada percebem que concorrem com um imenso contingente de desempregados, e quando encontram uma oferta são frustrados pelo fato de não possuírem os requisitos exigidos pelo posto de trabalho, principalmente o da experiência profissional. 
Ainda segundo o autor, evidências apontam que o ensino do empreendedorismo deve ser transformado em questão prioritária nas decisões sobre o processo educativo. Estudos recentes mostram que não se pode mais pensar somente em preparar as novas gerações para um futuro de emprego formal, com carteira assinada e garantias trabalhistas, pois este formato de trabalho formal corre o risco de deixar de existir num futuro próximo. O discurso corrente, segundo tais estudos, baseia-se na necessidade de o trabalhador desenvolver de forma autônoma, novas competências e habilidades para que consiga desenvolver produtividade que gere valor agregado (COAN, 2011).

No Brasil, embora as produções científicas, que trazem experiências sobre educação empreendedora dentro das IES sobre ensino do empreendedorismo tenha aumentado nos últimos anos, este número ainda é considerado pequeno comparado com outros países (FERNANDES, 2014).

Coan (2012) em sua tese de doutorado que também discorre sobre o tema de ensino do empreendedorismo, traz alguns desses trabalhos, apresentados no quadro a seguir:

\begin{tabular}{|l|l|}
\hline Autor(es) & Abordagem \\
\hline Pereira (2001) & $\begin{array}{l}\text { Apresenta procedimentos metodológicos para o desenvolvimento e a atualização } \\
\text { de habilidades do sujeito empreendedor, notadamente do jovem universitário, } \\
\text { que precisa ser formado com uma nova mentalidade para atender e se adequar } \\
\text { às mudanças do mundo atual. }\end{array}$ \\
\hline Miranda (2002) & $\begin{array}{l}\text { elaborou uma metodologia para introdução do ensino de empreendedorismo nos } \\
\text { cursos técnicos de nível médio. }\end{array}$ \\
\hline Wolf (2004) & $\begin{array}{l}\text { descreve acerca da aceitação do aprendizado do empreendedorismo como } \\
\text { facilitador do sucesso profissional de alunos do ensino médio. }\end{array}$ \\
\hline Bastos et al (2006) & $\begin{array}{l}\text { entendem que o projeto do empreendedorismo na escola básica como matéria } \\
\text { extracurricular, transdisciplinar, permite incorporar ao ensino curricular } \\
\text { obrigatório outros conhecimentos que provoquem nos jovens novos } \\
\text { comportamentos e novas posturas a partir do ideal empreendedor. }\end{array}$ \\
\hline $\begin{array}{l}\text { Friedlaender (2004) } \\
\text { Santos (2002) }\end{array}$ & $\begin{array}{l}\text { reforçam a necessidade de formar para o empreendedorismo, pois o } \\
\text { empreendedor sabe buscar as oportunidades, tem iniciativa, é persistente e } \\
\text { comprometido com seu projeto. Também é exigente consigo mesmo e sabe que } \\
\text { enfrentará riscos estabelece e procura cumprir metas, busca informações e sabe } \\
\text { utilizá-las, sabe usar a arte da comunicação e persuasão e é independente e } \\
\text { autoconfiante. }\end{array}$ \\
\hline
\end{tabular}

Gráfico 6: Síntese de trabalhos sobre Ensino do Empreendedorismo

Fonte: Coan (2012) 
Complementando o cenário exposto no quadro de Coan (2012) a presente pesquisa também pôde ancorar-se em trabalhos semelhantes. Sem a pretensão de esgotar o assunto ou mesmo de mapear todos os estudos, o objetivo deste levantamento foi buscar compreender um pouco melhor sobre pesquisas que tiveram como proposta, os estudos do ensino do empreendedorismo no cenário nacional, por meio dos trabalhos e publicações científicas listadas a seguir:

\begin{tabular}{|c|c|}
\hline Autor(es) & Pesquisa \\
\hline BAUR, et.al (2016) & $\begin{array}{l}\text { Perfil Empreendedor dos Estudantes de Odontologia da Universidade Federal } \\
\text { de Santa Catarina }\end{array}$ \\
\hline KRUGÜER et.al (2017) & $\begin{array}{l}\text { As Características Comportamentais Empreendedoras em Alunos do Ensino } \\
\text { Superior }\end{array}$ \\
\hline ROCHA e BACHI (2010) & $\begin{array}{l}\text { Ensino de Empreendedorismo nos Cursos de Graduação em Administração na } \\
\text { cidade de Fortaleza: Um Estudo Comparativo dos Conteúdos e Instrumentos } \\
\text { Pedagógicos }\end{array}$ \\
\hline SILVA (2015) & $\begin{array}{l}\text { Ensino do Empreendedorismo na Educação Básica: A Formação do Cidadão } \\
\text { Empreendedor em Questão }\end{array}$ \\
\hline SOUZA et.al (2004) & $\begin{array}{l}\text { Métodos e Técnicas de Ensino e Recursos Didáticos para o ensino do } \\
\text { Empreendedorismo em IES Brasileiras }\end{array}$ \\
\hline TERRIM et.al (2015) & $\begin{array}{l}\text { Empreendedorismo Em Saúde: Relato de Modelo de Empresa Júnior em } \\
\text { Medicina. }\end{array}$ \\
\hline TORRES (2018) & $\begin{array}{l}\text { Estudo de Impacto do Programa de Treinamento Comportamental em } \\
\text { Empreendedorismo }\end{array}$ \\
\hline SOUZA e SARAIVA (2010) & $\begin{array}{l}\text { Práticas e Desafios do Ensino de Empreendedorismo na Graduação em uma } \\
\text { Instituição de Ensino Superior }\end{array}$ \\
\hline VIEIRA et.al (2015) & $\begin{array}{l}\text { O Ensino de Empreendedorismo nos Cursos de Graduação em Administração: } \\
\text { Um Estudo Comparativo entre as Universidades Estaduais de Londrina e } \\
\text { Maringá. }\end{array}$ \\
\hline $\begin{array}{l}\text { MARION-SANTOS e } \\
\text { PAIXÃO (2013) }\end{array}$ & $\begin{array}{l}\text { Estudo do Perfil Empreendedor do Aluno de Graduação em Administração } \\
\text { egresso de Instituições de Ensino da Região de Jundiaí }\end{array}$ \\
\hline $\begin{array}{l}\text { HENRIQUE e CUNHA } \\
(2006)\end{array}$ & $\begin{array}{l}\text { Metodologias, Recursos e Práticas Didático-Pedagógicas no Ensino de } \\
\text { Empreendedorismo em Cursos de Graduação e Pós-Graduação Nacionais e } \\
\text { Internacionais }\end{array}$ \\
\hline MOTA (2013) & $\begin{array}{l}\text { Diagnóstico da Capacidade Empreendedora de Estudantes Universitários e } \\
\text { Profissionais de Micro Pequenas e médias empresas }\end{array}$ \\
\hline ROCHA e FREITAS (2014) & $\begin{array}{l}\text { Avaliação do Ensino de Empreendedorismo entre Estudantes Universitários } \\
\text { por meio do Perfil Empreendedor }\end{array}$ \\
\hline PEDROSO et.al (2017) & $\begin{array}{l}\text { Avaliação do Perfil Empreendedor de Estudantes em uma Faculdade } \\
\text { Confessional: Estratégias, Resultados e Limitações na Criação de uma Cultura } \\
\text { Universitária Empreendedora }\end{array}$ \\
\hline PIETROVSKI et.al (2019) & $\begin{array}{l}\text { Análise do Potencial Empreendedor em alunos do Ensino Superior: Aplicação } \\
\text { da Teoria à Prática }\end{array}$ \\
\hline
\end{tabular}




\begin{tabular}{|c|c|}
\hline COAN (2012) & $\begin{array}{l}\text { Educação Para o Empreendedorismo Como Estratégia para Formar um } \\
\text { Trabalhador de Novo Tipo }\end{array}$ \\
\hline $\begin{array}{l}\text { ECKERT et.al (2013) } \\
(2002)\end{array}$ & $\begin{array}{l}\text { O Perfil Empreendedor na Graduação: Um Estudo Comparativo entre } \\
\text { Ingressantes e Concluintes }\end{array}$ \\
\hline $\begin{array}{l}\text { LUCENA e CENTURION } \\
(2011)\end{array}$ & $\begin{array}{l}\text { As Contribuições da Pedagogia Freireana ao Desenvolvimento de Profissionais } \\
\text { Empreendedores na Área de Administração }\end{array}$ \\
\hline ITELVINO et.al (2018) & Formação Empreendedora para Geração de Inovações Sociais \\
\hline FERNANDES (2014) & $\begin{array}{l}\text { O Ensino do Empreendedorismo: Um Estudo de Caso nas Áreas da Saúde, } \\
\text { Exatas e Humanas em Instituições de Ensino Superior do Interior Paulista }\end{array}$ \\
\hline FERREIRA et.al (2010) & $\begin{array}{l}\text { Empreendedorismo e Práticas Didáticas nos Cursos de Graduação em } \\
\text { Administração: os Estudantes levantam o problema }\end{array}$ \\
\hline MOREIRA et.al (2019) & $\begin{array}{l}\text { A inserção da Educação Empreendedora nos cursos de Administração em } \\
\text { Instituições de Ensino Superior da região metropolitana de Belém - PA. }\end{array}$ \\
\hline BOTTONI et.al (2019) & Empreendedorismo no Campo da Saúde no Brasil. \\
\hline REINA e SANTOS (2017) & $\begin{array}{l}\text { Educação Empreendedora: práticas educativas para dinamizar a ascensão } \\
\text { pessoal e profissional dos alunos }\end{array}$ \\
\hline MINELLO et.al (2017) & $\begin{array}{l}\text { Características Comportamentais Empreendedoras: um estudo com } \\
\text { acadêmicos de administração de uma universidade brasileira }\end{array}$ \\
\hline SANTOS et.al (2014) & Educação Empreendedora, Pequenos Negócios, Desafios e Perspectivas \\
\hline SILVA e PENA (2017) & $\begin{array}{l}\text { O "BÊ-Á-BÁ" do ensino do empreendedorismo: uma revisão da literatura sobre } \\
\text { os métodos e práticas da educação empreendedora }\end{array}$ \\
\hline BARLACK (2014) & $\begin{array}{l}\text { Comportamento Empreendedor: Um Estudo empírico baseado no referencial } \\
\text { de McClelland }\end{array}$ \\
\hline KAUR e BAINS (2013) & Understanding The Concept Of Entrepreneur Competency \\
\hline RAMALHO et.al (2016) & $\begin{array}{l}\text { Análise do Perfil Empreendedor dos Discentes dos Cursos de Ciências } \\
\text { Contábeis e Administração nas Instituições de Ensino Superior do Município } \\
\text { de Viçosa, MG. }\end{array}$ \\
\hline CUNHA et.al (2009) & $\begin{array}{l}\text { As vantagens de aprendizado do empreendedorismo: um estudo desde o } \\
\text { ensino de base até o superior }\end{array}$ \\
\hline LIMA et.al (2014) & $\begin{array}{l}\text { Caminhos para uma melhor Educação Superior em Empreendedorismo no } \\
\text { Brasil }\end{array}$ \\
\hline
\end{tabular}

Quadro 12: Trabalhos científicos sobre o ensino do empreendedorismo no ensino superior Fonte: Autora

O que se pode constatar com tais pesquisas é um aumento no número de produções envolvendo o ensino do empreendedorismo, o que significa dizer que está havendo uma preocupação maior com a formação empreendedora por parte de pesquisadores do tema e isso pode fomentar o setor, favorecendo um incremento nessa cultura do empreendedorismo na educação.

Dolabela (2008) está entre os autores que mais trabalham em prol do ensino do empreendedorismo. Defende a ideia de educar os atuais e futuros trabalhadores para o 
empreendedorismo por meio da pedagogia empreendedora. Tem organizados inúmeros materiais para alunos e professores para fomentar os trabalhos que envolvem a formação empreendedora nas escolas.

Nesse contexto, a tarefa da educação empreendedora seria, principalmente, a de fortalecer os valores empreendedores na sociedade, a capacidade individual e coletiva de gerar valores para toda a comunidade, de inovar, de ser autônomo e de buscar a sustentabilidade (LIMA et.al 2014). A tese do autor é a de que o atual modelo educacional se ancora numa cultura de preparar crianças, jovens e adultos, exclusivamente, na busca de um emprego. Contrário a esse modelo, que considera anacrônico, o autor insiste na necessidade de se praticar os princípios do empreendedorismo na escola como um meio para mudar o paradigma educacional (ECKERT et.al. 2013).

A meta principal da pedagogia empreendedora é inserir o empreendedorismo na educação básica, além de procurar articulá-lo com a construção de tecnologias de desenvolvimento social local sustentável (DOLABELA, 2008).

A criação de uma metodologia para o desenvolvimento dessas competências, nos mais variados cursos e profissões, requer uma mudança de paradigma, por envolver bem mais que apenas a aquisição de conhecimentos. Para Henrique e Cunha (2006), o ensino do empreendedorismo e do perfil empreendedor deve envolver os quatro pilares da educação para o século XXI da UNESCO ${ }^{14}$. Segundo Delors (1999, pg. 89),

\begin{abstract}
... a prática pedagógica deve preocupar-se em desenvolver quatro aprendizagens fundamentais, que serão para cada indivíduo os pilares do conhecimento: aprender a conhecer indica o interesse, a abertura para o conhecimento, que verdadeiramente liberta da ignorância; aprender a fazer mostra a coragem de executar, de correr riscos, de errar mesmo na busca de acertar; aprender a conviver traz o desafio da convivência que apresenta o respeito a todos e o exercício de fraternidade como caminho do entendimento; e, finalmente, aprender a ser, que, talvez, seja o mais importante por explicitar o papel do cidadão e o objetivo de viver.
\end{abstract}

\footnotetext{
${ }^{14}$ Os quatro pilares da Educação são conceitos de fundamento da educação baseados no Relatório para a UNESCO sobre Educação para o Século XXI, coordenado por Jacques Delors, em seu livro Educação: Um Tesouro a Descobrir (1999). Estas quatro vias do saber, na verdade, constituem apenas uma, dado que existem pontos de interligação entre elas., eleitos como os quatro pilares fundamentais da educação. $O$ ensino, tal como o conhecemos, debruça-se essencialmente sobre o domínio do aprender a conhecer e, em menor escala, do aprender a fazer. Estas aprendizagens, direcionadas para a aquisição de instrumentos de compreensão, raciocínio e execução, não podem ser consideradas completas sem os outros dois domínios da aprendizagem, muito mais complicados de explorar, devido ao seu caráter subjetivo e dependente da própria entidade educadora (DELORS, 1999).
} 
Ainda segundo Delors (1999), na visão dos quatro pilares do conhecimento, pode-se prever grandes mudanças na educação. O ensino-aprendizagem voltado apenas para a absorção de conhecimento e que tem sido objeto de preocupação constante de quem ensina deverá dar lugar ao ensinar a pensar, saber comunicar-se e pesquisar, ter raciocínio lógico, fazer sínteses e elaborações teóricas, ser independente e autônomo; enfim, ser socialmente competente.

Para Dornelas (2013), todas as características citadas por Delors (1999) são elementos favoráveis ao ensino do empreendedorismo para o desenvolvimento do perfil empreendedor. Logo, a visão dos quatro pilares da educação pode ser estudada como estratégia pedagógica ao processo de ensino do empreendedorismo. Ainda para Dornelas (2013), um curso voltado para o conteúdo do empreendedorismo deveria centrar-se em objetivos que proporcionassem ao estudante uma formação alinhada com a amplitude dos aspectos relacionados ao campo do empreendedorismo.

A ação fundamental no processo de educação empreendedora, de acordo com Krüger et.al (2019), tem como primeiro passo permitir que os alunos experimentem a realidade, para depois aprenderem conceitos. Desenvolver o comportamento empreendedor no aluno é capacitá-lo para a criação, condução e implementação do processo criativo proporcionando a oportunidade de elaborar novos planos de vida, de trabalho, de estudo, de negócios, transformando-se, deste modo, no ator responsável pelo seu desenvolvimento pessoal e profissional (CUNHA et.al 2009).

Desta forma, a educação empreendedora pode ser entendida como um processo dinâmico de conscientização, associação e aplicação, que envolve transformar a experiência e o conhecimento em resultados concretos, aprendidos e praticados. Trata-se, portanto, desenvolvimento de conhecimento, comportamento e aprendizagem efetivo-emocional (KAUR e BAINS, 2013).

O Discurso sobre educação empreendedora, portanto, permeia as propostas e políticas educacionais para a formação dos jovens estudantes, em diversos países, por meio de organizações internacionais como a Organização de Cooperação e de Desenvolvimento (OCDE), a Organização das Nações Unidas (ONU), da Organização das Nações Unidas para a 
Educação, a Ciência e a Cultura (UNESCO), como instituições que buscam fomentar a formação empreendedora por meio da educação nos mais diversos níveis (COAN, 2012).

Para Silva (2015), esses organismos enfatizam em seus discursos que o desenvolvimento econômico das nações está ligado ao espírito empreendedor na sociedade e que países em desenvolvimento precisam de indivíduos com este perfil para desenvolverem ferramentas, tecnologias, produtos inovadores, de forma a contribuir para a geração de empregos, renda e desenvolvimento social.

Na América Latina, uma das primeiras manifestações em prol do empreendedorismo na educação foi feita pela Oficina Regional de Educação para América Latina e o Caribe (OREALC - UNESCO), anunciada no Projeto Regional de Educação para a América Latina e o Caribe - PRELAC ${ }^{15}$ que incluiu um quinto pilar, o "aprender a empreender" aos quatro pilares já estabelecidos, em 1996, pelo Relatório Delors (1999), da Comissão para a Educação no século XXI da UNESCO. Segundo a autora,

Ao acrescentar o "aprender a empreender" como pilar da política educacional, a UNESCO procura estabelecê-lo como eixo da educação, atrelando-o à missão de gerar alternativas para o desemprego de modo a assegurar que mesmo em tempos de crise a humanidade mantenha a produção coletiva de riquezas preservando a apropriação privada (COAN, 2012, pg. 04).

Apesar da crescente popularidade e importância dada ao tema educação empreendedora, entende-se que ainda necessita de estudos mais apurados para se compreender o nível de amplitude que se está sendo dado pelas instituições de ensino, sendo uma habilidade a ser formada nos futuros profissionais para enfrentarem os desafios da atualidade, em que trabalho, empregabilidade e empreendedorismo são aspectos correlacionados na busca pelas oportunidades profissionais (KAUR e BAINS, 2013).

Em instituições de ensino superior, muito se tem falado sobre instituições de ensino com visão empreendedora e seu impacto na sociedade, destacando como novas atribuições das universidades modernas, a promoção, o patrocínio e até mesmo a indução de programas

15 O Projeto Regional de Educação para a América Latina e o Caribe - PRELAC é uma declaração de consenso entre os Ministros da Educação sobre a situação e a projeção da educação na região, com o slogan "Educação para todos". Foi aprovado em novembro de 2002, em Havana, Cuba (COAN, 2011) 
voltados para a difusão e fortalecimento do empreendedorismo em seus cursos (SANTA RITA et.al, 2008).

A UNESCO conceitua Instituições de ensino superior, as IES, como instituições que têm por missão educar, formar e realizar pesquisas, contribuindo para o desenvolvimento cultural, social e econômico da sociedade, promovendo, gerando e difundindo conhecimentos em um contexto de pluralismo e diversidade cultural, enfrentando o desafio de serem a alavanca da sociedade do conhecimento, tendo que promover mudanças internas e de relações com a sociedade (COAN, 2011).

Assim, hoje a universidade necessita adaptar-se para enfrentar estas múltiplas missões, seja na educação, pesquisa e extensão, também a valorização econômica dos seus resultados, a difusão da cultura e da informação científica e técnica, no contexto da cooperação internacional. O papel da universidade, além de promover o desenvolvimento acadêmico, centra-se também em transformar a realidade social por meio de seus produtos (ECKERT et.al. 2013).

O ensino superior brasileiro, segundo Pietrovski et.al (2019), trilha duas perspectivas na formação de seus alunos: (i) diversificação/diferenciação institucional e (ii) estrutura de mercado. Não se trata de perspectivas excludentes, mas de configurações institucionais com objetivos e finalidades distintas. Diversificar-se significa estabelecer uma forma de atuação que permita às faculdades diferenciarem-se dos modelos clássicos já estabelecidos, ofertando ao aluno a possibilidade de modelos de ensino e aprendizagem mais flexíveis e voltados para a formação para o mercado de trabalho.

A diferenciação e a diversificação têm aberto portas às instituições que queiram voltar suas atividades ao ensino e formação de profissionais de mercado a custos mais acessíveis, à oferta de cursos na modalidade online ou até mesmo a cursos híbridos com menor intensidade de aulas. De outro lado, uma estrutura voltada para o mercado permite às instituições de ensino superior adaptar seus cursos e modelos pedagógicos para a formação de profissionais mais adequados à sua realidade local e regional. A universidade tem como uma de suas funções transformar a realidade social por meio de seus cursos e, dessa forma, impactar a carreira do aluno. O jovem pode criar empresas como forma de emprego alternativo e de formação de carreira profissional. O papel do empreendedor como 
agente de transformação econômica e social implica desenvolver competências empresariais cujo processo pode ser desencadeado nessas instituições (PIETROVSKI et.al, 2019).

As Instituições de Ensino Superior possuem este segundo objetivo, o de atender as necessidades do desenvolvimento regional onde estão inseridas. Ainda, para serem as grandes provedoras da matéria-prima da sociedade do conhecimento, têm que compreender que suas ações devem ser amplas e profundas o suficiente para interferir no meio em que atuam, podendo então proporcionar resultados sustentáveis e mensuráveis. Nesse cenário, o ensino do empreendedorismo tem se mostrado como instrumento de mudança no perfil sócio econômico brasileiro, podendo aprimorar a distribuição de renda e alterar o nível de competitividade no mercado globalizado cursos (SANTA RITA et.al, 2008).

Uma das estratégias que vem sendo aplicadas nas Instituições de Ensino Superior IES brasileiras é prover suas grades curriculares com o ensino de empreendedorismo em conjunto com as práticas didático-pedagógicas voltadas para essa abordagem, promovendo atividades interdisciplinares. Nessa perspectiva, a educação empreendedora tem voltado seus esforços para o ensino do empreendedorismo no ensino superior, em razão da interface entre inovação, oportunidade, gestão e desenvolvimento econômico (ROCHA e FREITAS, 2014). Com isso, diversos processos pedagógicos têm sido aplicados, resultando na criação das atividades educacionais de formação em empreendedorismo, como palestras, recomendações de leituras, estudos de caso, visita a empresas, brainstorming, simulações e projetos desenvolvidos em grupos assim como planos de negócios, entrevistas com empreendedores, uso de filmes e jogos sobre estratégias empreendedoras (HENRIQUE e CUNHA, 2006).

Tal estratégia resultaria em disponibilizar ao mercado não mais simples profissionais prontos para exercerem suas atividades como colaboradores, mas sim como profissionais detentores de conhecimentos e aptos a gerir um negócio, assim como buscar inovações dentro do segmento em que estão inseridos, ou mesmo atuando como intraempreendedoras, contribuindo para a contínua inserção e sobrevivência das instituições.

Interessante destacar que, até poucos anos, acreditava-se que as habilidades empreendedoras de forma alguma poderiam ser ensinadas, e as pessoas que não nasciam com o "dom" empreendedor eram desaconselhadas a buscar seu desenvolvimento 
(DORNELAS, 2014). Pode-se afirmar, então, que o aumento no interesse pelos processos e metodologias de ensino do empreendedorismo teve início em estudos que questionavam esse difundido entendimento de que a capacidade empreendedora é inata ao ser humano, só podendo ser herdada geneticamente. Em decorrência disso, segundo o autor, o empreendedorismo como disciplina foi se desenvolvendo por meio de estudos dispersos, por pesquisadores de diversas áreas de conhecimento e motivados por necessidades de mercado.

Para Filión (1999), o desenvolvimento do empreendedorismo como disciplina não seguiu padrão semelhante ao de outras disciplinas. Na verdade, grande número de pesquisadores, cada um usando sua cultura, sua lógica e metodologia estabelecidos em graus variados em seus próprios campos de estudo, começou a interessar-se e a trabalhar no campo do empreendedorismo em seus pequenos espaços. Segundo o autor, empreendedorismo não é nem ciência, nem arte, é uma prática, por isso, a geração de conhecimento sobre empreendedorismo é definida pelos fins, ou seja, pela própria prática e experiência. Portanto, o ensino do empreendedorismo necessita ser constantemente contextualizado, expondo o aluno às situações-problemas reais, semelhantes àquelas que encontrará em sua carreira.

Para Katz (2003), o início do ensino de empreendedorismo teve origem nos EUA com Myles Mace lecionando o primeiro curso de empreendedorismo em fevereiro de 1947 na escola de Administração de Harvard. Nesta época, seus objetivos eram outros. Sua criação era voltada para objetivos completamente diferentes dos atuais: qualificar ex-combatentes da Segunda Guerra Mundial para o mercado de trabalho, principalmente a geração do auto emprego, visto que sua economia estava em transição devido ao colapso da indústria de armas (HENRIQUE e CUNHA, 2006; DOLABELA, 2008).

No entanto, o tema empreendedorismo não se difundiu entre os cursos de graduação e pós-graduação nos EUA, com o passar das décadas. A baixa extensão das atividades empreendedoras durante as décadas de 50 e 60 ocorria por conta do declínio do surgimento de novas corporações, faculdades e universidades, que poderiam incluir o empreendedorismo em seus currículos. Além disso, havia uma grande dependência financeira das universidades em relação às grandes corporações existentes, que financiavam pesquisas, doavam equipamentos e patrocinavam bolsas de estudos, além de promover clima de restrição nos docentes, de fomentar conteúdos voltados à criação de empresas. Apenas, a partir de 1970, as universidades começam a voltar suas grades curriculares para o tema (HENRIQUE E CUNHA, 2006, p. 03). 
Na década de 1990, houve um salto no número de instituições universitárias americanas implantando o ensino de empreendedorismo em suas grades curriculares, passando de pouco mais de 50 em 1975 para mais de 1.000 em 1988, sendo obrigatório o ensino do tema em cinco estados. Em 1994, aproximadamente 120.000 estudantes americanos estavam realizando cursos de empreendedorismo em uma infraestrutura que cresceu para 2.200 cursos, oferecidos em pelo menos 1.600 faculdades, 100 centros especializados, além da criação de 44 periódicos científicos em língua inglesa sobre o tema. Em 2004, aproximadamente 5,6 milhões de jovens americanos com idade até 34 anos estavam tentando iniciar seu próprio negócio. Destes novos empreendedores, um terço eram jovens de até 30 anos e mais de $80 \%$ dos que estavam na faixa dos 18 aos 34 diziam pretender abrir seu próprio negócio (KURATKO, 2007; DOLABELA, 2008; KATZ, 2003, HENRIQUE E CUNHA, 2006).

Dentro deste contexto, importa destacar que o ensino de empreendedorismo estava inserido no campo da administração como uma subárea e recentemente está sendo estudado como campo específico de conhecimento, porém com seus conceitos e metodologias ainda em fase de consolidação e formação, sem haver consenso dentre os autores. Isto ocorre devido, principalmente, aos diferentes significados de "empreendedorismo" empregados, a variedade de cursos de empreendedorismo e às diferentes formas com que o rótulo empreendedorismo é usado pelas universidades na promoção de agendas diversas (ROCHA e FREITAS, 2014; SOUZA e GUIMARÃES, 2006).

Ao redor do mundo, centenas de universidades já reconhecem o papel e o poder da educação empreendedora sobre a inovação e o desenvolvimento econômico de um país. Nos Estados Unidos, por exemplo, o Massachusetts Institute of Technology (MIT) ofereceu 60 cursos relacionados a empreendedorismo entre 2014 e 2016, além de cursos intensivos com viés prático e um programa de aceleração para empreendedores, dentre outras iniciativas. Como resultado dessa aposta de longo prazo, 30.000 empresas fundadas por ex-alunos do MIT estavam ativas no mercado em 2014, empregando 4,6 milhões de pessoas e produzindo receitas anuais de US\$ 1,9 trilhões - pouco mais que o PIB do Brasil de 2015, de acordo com o Banco Central (SEBRAE, 2017). 
Para Dolabela (2009), é evidente a grande contribuição que o sistema de ensino universitário pode oferecer para o estabelecimento e o fortalecimento das mudanças nesse perfil empreendedor. Hoje a universidade é demandada a adaptar-se para enfrentar essas múltiplas tarefas de formação, pesquisa e difusão de cultura e informação em contexto caracterizado pela democratização, revolução tecnológica, mudanças nas relações de trabalho e necessidade de estabelecer vínculos com o mercado. Isso traz como consequência a renovação permanente de seus projetos pedagógicos, possibilitando o desenvolvimento de novas tecnologias e metodologias. Para Souza et.al (2004, p.07):

\footnotetext{
... no atual contexto de mudança e avanço tecnológico, a estrutura de emprego modifica-se, formações que respondiam às demandas do mercado, hoje perdem espaço para novas carreiras e serviços surgem, ao sistema de ensino é demandado o desenvolvimento de novas competências. Torna-se, cada vez mais frequente, a necessidade dos egressos do ensino superior criarem, por si mesmos, seus postos de trabalho, o que leva a um processo de revisão e adequação do processo ensinoaprendizagem universitário, e a importância da adoção de projetos pedagógicos desenhados com metodologias alternativas e inovadoras. Além disso, em uma visão shumpeteriana, as empresas são consideradas o lócus privilegiado da inovação e o empreendedor o ator principal do progresso técnico, do desenvolvimento sustentável das nações.
}

A implementação de cursos voltados para o ensino do empreendedorismo nas universidades justifica-se pela crescente conscientização no sentido de proporcionar aos estudantes, competências que possibilitem, não só a sua inserção no mundo do trabalho, como, também, sua sobrevivência frente a competitividade profissional. Desenvolver o perfil empreendedor é capacitar o aluno para que crie, conduza e implemente o processo criativo de elaborar novos planos de vida, de trabalho, de estudo, de negócios, sendo, com isso, responsável pelo seu próprio desenvolvimento e o de sua organização. Sob essa perspectiva, ao disseminar a cultura do empreendedorismo está sendo criado um novo comportamento, individual e organizacional, que ainda busca metodologias que possibilitem realizar essa formação de forma efetiva (SOUZA et.al, 2004).

Sendo o empreendedorismo, sobretudo no Brasil, um campo de estudo ainda em desenvolvimento, por não existir uma teoria consolidada a respeito do tema, não existe também uma única metodologia para o desenvolvimento de suas competências (SOUZA, et.al 2004; HENRIQUE e CUNHA, 2006). Para os autores, o ensino do empreendedorismo envolve bem mais que aquisição de conhecimentos e competências, envolve também o aprender a aprender, a ser, a fazer e, aprender a conviver, proporcionando uma relação 
proativa entre aluno e aprendizado. As universidades, portanto, são chamadas a desempenhar um papel estratégico no desenvolvimento do setor produtivo, impondo-lhes a busca de novas abordagens curriculares e de relações com os demais setores da sociedade. Nesse sentido, surge a questão de como as universidades buscam alternativas para desenvolverem uma formação empreendedora nas diferentes áreas do conhecimento e, por excelência, na geração de inovação, passando a formar pessoas proativas, criativas, inovadoras, empreendedoras, que na visão de Schumpeter (1997) são vistas como motores da economia, agentes de inovação e mudanças, capazes de desencadear o crescimento econômico do país.

Muito se tem falado sobre instituições de ensino com visão empreendedora, seu papel e impacto na sociedade, destacando como novas atribuições das universidades modernas, a promoção, o patrocínio e até mesmo a indução de programas voltados a difusão e fortalecimento do empreendedorismo entre seus alunos (SANTA RITA et.al, 2008). Para os autores, as IES desenvolvem um papel de suma importância no desenvolvimento econômico e social das regiões onde estão inseridas. Ainda, para serem as grandes provedoras da matéria-prima da sociedade do conhecimento, têm que compreender que suas ações devem ser amplas e profundas o suficiente para interferir no meio em que atuam, podendo então proporcionar resultados sustentáveis e mensuráveis em suas regiões. Nesse cenário, o ensino do empreendedorismo tem mostrado ser este instrumento de mudança no perfil sócio econômico brasileiro, podendo aprimorar a distribuição de renda e melhorar aspectos de competitividade.

Para Vieira, Melatti e Ribeiro (2011), o objetivo do ensino do empreendedorismo, portanto, deve ser construir uma visão de sociedade empreendedora e o melhor caminho é por meio de práticas didáticas que estimulem e desenvolvam nos alunos da graduação, habilidades e capacidades necessárias à gestão de um empreendimento, que pode ser uma empresa ou um projeto, ou seja, algo que se queira investir - tempo, dinheiro, expertise etc. A efetiva aprendizagem da disciplina de Empreendedorismo depende da adoção de métodos e práticas de ensino específicas, e não mais dos modelos da educação tradicional.

Dessa forma, os objetivos propostos de ensino-aprendizagem devem levar o estudante a ser capaz de adquirir plena consciência sobre os conceitos de 
empreendedorismo, como criatividade, inovação, busca de oportunidade, planejamento e prospecção de novos negócios, fazer previsões, assumir riscos, persistir, lidar com conflitos, adquirir autocontrole, aprender com a tomada de decisão, erros e acertos, trabalhar em equipe, formar uma rede de contatos e administrar o negócio de forma sustentável (ROCHA e FREITAS, 2014).

Em pesquisa realizada pelo SEBRAE (2017), foram diagnosticados alguns parâmetros da realidade do empreendedor na prática, e que podem servir de base para a construção de instrumentos pedagógicos que atendam às lacunas percebidas e trazidas por todos os trabalhos relacionados ao tema. A pesquisa foi realizada com empreendedores que qualificaram com uma nota de 0 a 10 os principais desafios que vivem diariamente, divididos em 10 categorias diferentes. As categorias em que a maior proporção de empreendedores afirmou ter muitos desafios (notas 9 e 10) foram Acesso a crédito e/ ou Investimentos (22\%), Gestão de Pessoas (18\%), Gestão Financeira (17\%) e Inovação (17\%), sendo o maior desafio a gestão de pessoas, o desenvolvimento de lideranças, uma habilidade que pode ser desenvolvida dentro das Universidades, independentemente do tipo de curso. Outros resultados levantados pela pesquisa são:

- Há a percepção de que os desafios em empreender são maiores entre potenciais empreendedores do que entre os próprios empreendedores. Entre 10 possíveis desafios do empreendedor, na escala entre 1 e 10, a média geral entre os jovens empreendedores é 5,1. Quando a pergunta é feita para quem quer, mas ainda não abriu um negócio, a média sobe para 6. Parece que alunos que ainda não empreenderam possuem percepção de desafios maior do que os empreendedores. De qualquer maneira, essa percepção pode desmotivar potenciais empreendedores, e é possivelmente um dos motivos de parte deles nunca chegar a realizar sua vontade de abrir um negócio. O potencial empreendedor, assim, precisa enxergar que os desafios para empreender existem e que correr riscos é necessário e também parte do processo de ter um negócio. Essa visão, no entanto, é mais clara quando se tem experiências práticas, algo que a universidade poderia oferecer mais.

- A figura do mentor - alguém mais experiente que dá conselhos e compartilha experiências - é importante para transmitir valores, ideias, atitudes e ajudar na 
tomada de decisão dos empreendedores universitários. Na falta de apoio qualificado nas universidades e em casa, é natural que jovens busquem pessoas com experiência para serem seus "gurus". Os mentores também são importantes até para aqueles que nem iniciaram seus negócios. Entre os potenciais empreendedores, $66,3 \%$ possuem mentor mesmo antes de empreender, e 60,1\% concordam que ele foi essencial para despertar o desejo em empreender.

- Há uma relação direta entre cursar uma disciplina de empreendedorismo e desenvolver o seu perfil empreendedor. Quanto maior o envolvimento com a temática empreendedora, maior a proporção de universitários que realizaram disciplinas do tipo. Cerca de $46 \%$ de alunos empreendedores já cursaram essas disciplinas, número superior ao de potenciais empreendedores $(38,8 \%)$, por sua vez superior ao de alunos que não pensam em ter um negócio (24\%). O grupo que cursou disciplinas de empreendedorismo é o mesmo que pretende empreender nos próximos 3 anos.

- Poucos cursos oferecem disciplinas de empreendedorismo. Aproximadamente $50 \%$ dos cursos de engenharias e ciências sociais aplicadas (administração e outras), há disciplinas de empreendedorismo. Em contrapartida, outras áreas de conhecimento têm pouquíssima oferta de disciplinas, como ciências agrárias, da saúde, biológicas e humanas - em torno de $16 \%$ de oferta das disciplinas para esses cursos, em média. Uma maneira de ampliar e democratizar o acesso a elas é permitir que sejam frequentadas por alunos de diferentes cursos, o que é o caso de disciplinas abertas ou interunidades ou disciplinas transversais. Empreender é uma prática interdisciplinar, e muitos futuros sócios ou parceiros podem se encontrar em disciplinas de empreendedorismo.

Tais mudanças são responsáveis por criar no universo educacional, a necessidade de atualizações constantes, inovação, busca acirrada de diversos tipos de informação e acesso a novas tecnologias.

Para Dolabela (2009), o histórico do ensino de empreendedorismo no Brasil já pode ser considerado como um avanço. Para o autor, empreendedores merecem o valor e o respeito que lhes são dados, pois são os responsáveis por gerar riquezas na economia e por 
serem contribuintes diretos ao processo de desenvolvimento do país, passando a ser o pensamento de vários estudiosos brasileiros com o ensino universitário do tema empreendedorismo. Tal marco ocorre na década de 80, quando se começa a ofertar disciplinas na graduação, pós-graduação e extensão, ligadas ao estudo e desenvolvimento de empreendedores.

Nessa lógica, podem ser considerados mais dois objetivos do ensino superior, o desenvolvimento de competências empreendedoras e a disseminação da cultura do empreendedorismo, que, de certa forma, são estratégicos para a inserção do homem no mercado de trabalho (SOUZA et.al, 2004). Para os autores, a formação do empreendedor passa pela aquisição de conhecimento e habilidades, experiências, capacidade criativa e inovadora. Trata-se do desenvolvimento do perfil empreendedor como sendo a capacitação da pessoa para criar, conduzir e implementar o processo criativo, elaborar novos planos de vida, trabalho, estudo e negócio, sendo com isso responsável pelo seu próprio desenvolvimento, de sua organização e da comunidade. Nessa perspectiva, o desenvolvimento de competências empreendedoras surge como desafio para as universidades, que em conjunto com o setor produtivo e o próprio Estado necessitam estabelecer novas formas de relações, e desenvolverem novas metodologias de ensino.

Dolabela (2009) amplia esta discussão ao defender que o ensino do tema deve ser inserido e trabalhado muito antes do ensino superior. Para o autor, o ensino do empreendedorismo deve ser iniciado com alunos desde a educação básica e fundamental, a fim de desenvolver um perfil crítico e observador nos estudantes. Para o autor, tal estratégia promove um desenvolvimento não só nos estudantes, mas também na sociedade em que estão envolvidos, por despertar questões de sustentabilidade, inovação, estímulo à capacidade de tomada de decisão, transportando o conceito que nasceu na empresa para todas as áreas da atividade humana. $\mathrm{O}$ autor conclui que não se trata de uma estratégia pedagógica destinada exclusivamente a preparar os alunos para criar uma empresa, mas, para desenvolver o potencial dos alunos para serem empreendedores em qualquer atividade que escolherem: empregados do governo, do terceiro setor, de grandes empresas, pesquisadores, artistas, e também, para serem proprietários de uma empresa, se esta for sua escolha. Cabe ao aluno fazer opções profissionais e decidir que tipo de empreendedor será. 
A pedagogia empreendedora ${ }^{16}$, termo cunhado pelo autor, propõe uma abordagem acentuadamente humanista, ao eleger como tema central, não o enriquecimento pessoal, mas a preparação do indivíduo para participar ativamente da construção do desenvolvimento social, com vistas à melhoria de vida da população e eliminação da exclusão social (Dolabela, 2009).

No quadro a seguir, estão relacionados os objetivos pedagógicos que segundo Dornelas (2013) devem servir de régua para a elaboração de propostas pedagógicas, em que os conteúdos programáticos contendo o tema empreendedorismo estejam voltados à formação de um perfil empreendedor que atenda às necessidades e prerrogativas listadas a seguir:

\begin{tabular}{|r|l|}
\hline 1 & Identificação e entendimento das habilidades do empreendedor \\
\hline 2 & Identificação e análise de oportunidades \\
\hline 3 & Como ocorre a inovação e o processo empreendedor \\
\hline 4 & Importância de empreendedorismo para o desenvolvimento econômico \\
\hline 5 & Como preparar e utilizar um plano de negócios \\
\hline 6 & Como identificar fontes e obter financiamento para o novo negócio \\
\hline 7 & Como gerenciar e fazer a empresa crescer \\
\hline
\end{tabular}

Quadro 13: Objetivos do ensino do empreendedorismo nas IES

Fonte: Dornelas (2013).

Nesse contexto, Rocha e Freitas (2014) destacam uma proposta elaborada pela European Commission Enterprise ECE - Comissão Empresarial Europeia - edição 2008, estruturada para a educação empreendedora no ensino superior dividida em três objetivos: (a) desenvolver espírito empreendedor entre os estudantes, (b) treinar estudantes para abrir uma empresa e administrá-la, (c) desenvolver habilidades empreendedoras necessárias para identificar e explorar oportunidades de negócios. O esquema a seguir detalha os três pilares que sustentam tais objetivos do ensino do Empreendedorismo:

\footnotetext{
${ }^{16}$ A pedagogia empreendedora refere-se à proposta concebida e criada por Fernando Dolabela (2009) e que visa difundir o ensino de empreendedorismo na educação básica, desde a educação infantil até o ensino profissionalizante.
} 


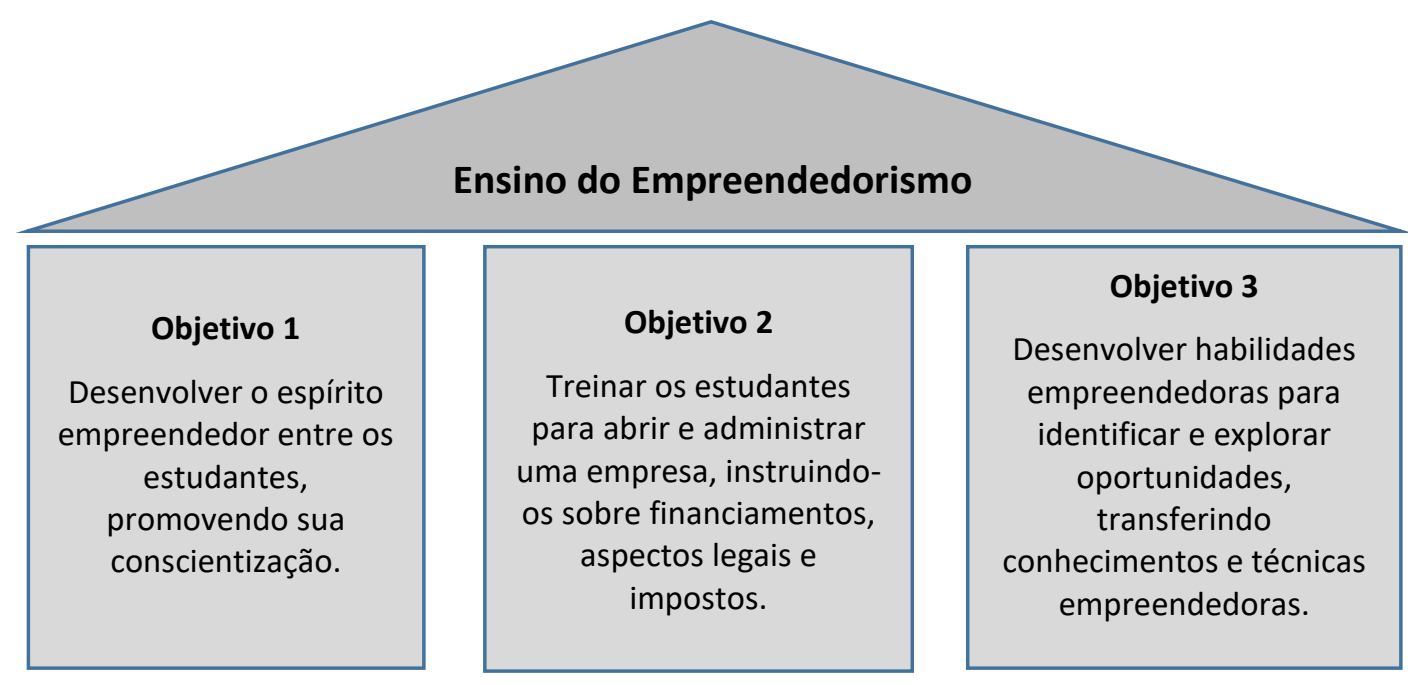

Figura 1: Pilares dos Objetivos do Ensino do Empreendedorismo Fonte: Rocha e Freitas (2014)

Teorias sobre educação empreendedora têm defendido uma linha pedagógica mais voltada para a prática, como sendo a mais apropriada para o ensino do Empreendedorismo. A aula tradicional expositiva, segundo Silva e Pena (2017) pode ser utilizada para repassar conteúdos teóricos e culturais do empreendedorismo, direcionando os demais aspectos da ação empreendedora para métodos e recursos pedagógicos mais dinâmicos.

Sendo o empreendedorismo, um processo de aprendizagem, uma teoria do empreendedorismo requer uma teoria de aprendizagem. No entanto, afirmam Pietrovski et.al (2019) que, nem tudo que se aprende sobre empreendedorismo garante o sucesso de um empreendedor, afinal, pode-se aprender com erros e acertos, ou, os erros de outros empreendedores. Fica mais fácil de aprender sobre o empreendedorismo quando se estuda a realidade de empreendedores, a realidade das empresas e experiências que ajudem a desenvolver competências empreendedoras.

A educação empreendedora consiste em um programa ou processo pedagógico com o intuito de desenvolver habilidades e atitudes empreendedoras que priorizam a integração entre estudantes, de modo a desenvolver atividades práticas e análise de casos reais. Esse processo deve oferecer aos estudantes a oportunidade de aprenderem através da experiência por meio de métodos que estimulem a exposição aos empreendedores de pequenas empresas e à comunidade local (SILVA e PENA, 2017; EUFRASIO e GOMES, 2012). 
Ainda segundo os autores, a importância dessa categoria educacional é, em grande parte, relacionada às habilidades do professor e ao uso de métodos apropriados ao ensino do tema. Por este motivo, a educação empreendedora é vista como uma metodologia heterogênea e deveria ser ensinada por meio de uma variedade de perspectivas teórico/práticas por meio de diversos métodos de ensino. Para os autores, "a implantação das aulas de empreendedorismo precisaria ser planejada e ministrada para fomentar uma ação desafiante, de modo a salientar a prática empreendedora dos acadêmicos" (SILVA e PENA, 2017, p. 374).

Rocha e Freitas (2014), Queiroz (2011) e Silva e Pena (2017) organizaram as diversas metodologias encontradas em referenciais teóricos, com suas respectivas aplicações pedagógicas, no ensino do empreendedorismo pelas instituições de ensino superior e que servem de balizador para inserção de dinâmicas de ensino pelas instituições. São práticas listadas em periódicos científicos, obras de estudiosos nacionais, além de relatórios internacionais que acompanham o desenvolvimento do tema empreendedorismo:

\begin{tabular}{|c|c|}
\hline $\begin{array}{c}\text { Métodos, Técnicas e } \\
\text { Recursos }\end{array}$ & Aplicações \\
\hline Aulas expositivas & $\begin{array}{l}\text { Transferir conhecimentos sobre o Empreendedorismo, as } \\
\text { características pessoais do empreendedor, os processos de inovação, } \\
\text { fontes de recursos, financiamentos e aspectos legais de pequenas } \\
\text { empresas. }\end{array}$ \\
\hline Visitas e contatos com empresas & $\begin{array}{l}\text { Estimular o networking e incitar o estudante a sair dos limites da IES } \\
\text { para entender o funcionamento de mercado na vida real. Desenvolver } \\
\text { visão de mercado. }\end{array}$ \\
\hline Brainstorming & $\begin{array}{l}\text { Construção da habilidade de concepção de ideias, prospecção de } \\
\text { oportunidades, reconhecendo-as como oportunidades } \\
\text { empreendedoras. Estimular o raciocínio intuitivo para criação de } \\
\text { novas combinações de serviços ou produtos, transformando-as em } \\
\text { inovações. }\end{array}$ \\
\hline Grupos de discussão & $\begin{array}{l}\text { Desenvolver a habilidade de testar novas ideias. Desenvolver a } \\
\text { capacidade de avaliar mudanças e 108prospectá-las como fonte de } \\
\text { oportunidades. }\end{array}$ \\
\hline $\begin{array}{l}\text { Aprendizagem Baseada em } \\
\text { Problemas - PBL }\end{array}$ & $\begin{array}{l}\text { abordagem de problemas para iniciar e motivar a aprendizagem de } \\
\text { conhecimentos social e profissional: a aprendizagem experiencial, } \\
\text { processos contínuos de ação e reflexão procedentes da experiência } \\
\text { vivenciada, e as descrições práticas de situações, em que o aluno é } \\
\text { constantemente incentivado a assumir responsabilidades e autodirigir } \\
\text { o processo educacional }\end{array}$ \\
\hline Ensino Experiencial & $\begin{array}{l}\text { Desenvolver a participação dos estudantes, de modo a desafiá-los } \\
\text { através de trabalhos práticos, mantendo contato com pessoas que já } \\
\text { praticam o empreendedorismo. As aulas não devem centrar-se em }\end{array}$ \\
\hline
\end{tabular}




\begin{tabular}{|c|c|}
\hline & $\begin{array}{l}\text { livros didáticos, mas permitir a experiência real dos estudantes por } \\
\text { meio do contato com a realidade dos empreendedores }\end{array}$ \\
\hline Plano de negócios & $\begin{array}{l}\text { Desenvolver as habilidades de planejamento, estratégia, marketing, } \\
\text { contabilidade, recursos humanos, comercialização. Desenvolver a } \\
\text { habilidade de avaliação do novo negócio, analisando o impacto da } \\
\text { inovação no novo produto ou serviço. Construir habilidade de avaliar } \\
\text { e dimensionar riscos do negócio pretendido. }\end{array}$ \\
\hline Jogos Empresariais e Simulações & $\begin{array}{l}\text { Atividades de tomada de decisões que envolvem um modelo de } \\
\text { operação de negócios, no qual os estudantes assumem a função de } \\
\text { administradores de uma empresa fictícia podendo assumir diversos } \\
\text { papeis gerenciais, funcionais, especialistas e generalistas }\end{array}$ \\
\hline Estudos de casos & $\begin{array}{l}\text { Construção da habilidade de pensamento crítico e de avaliação de } \\
\text { cenários e negócios. Desenvolver a habilidade de interpretação e } \\
\text { definição de contextos associados ao Empreendedorismo. }\end{array}$ \\
\hline Trabalhos teóricos em grupo & $\begin{array}{l}\text { Construção da habilidade de aprender coletivamente. Desenvolver a } \\
\text { habilidade de pesquisar, dialogar, integrar e construir conhecimentos, } \\
\text { buscar soluções e emitir juízos de valor na realização do documento } \\
\text { escrito }\end{array}$ \\
\hline Trabalhos práticos em grupo & $\begin{array}{l}\text { Construção da habilidade de atuar em equipe. Desenvolver a } \\
\text { habilidade de planejar, dividir e executar tarefas em grupo, de passar } \\
\text { e receber críticas construtivas. Ampliar a integração entre o saber e o } \\
\text { fazer. }\end{array}$ \\
\hline $\begin{array}{l}\text { Seminários e palestras com } \\
\text { empreendedores }\end{array}$ & $\begin{array}{l}\text { Transferir conhecimentos das experiências vividas por } \\
\text { empreendedores desde a percepção e criação do produto, abertura } \\
\text { do negócio, sucessos e fracassos ocorridos na trajetória } \\
\text { empreendedora. }\end{array}$ \\
\hline Criação de empresa & $\begin{array}{l}\text { Transpor as informações do plano de negócios e estruturar os } \\
\text { contextos necessários para a formalização. Compreender várias } \\
\text { etapas da evolução da empresa. Desenvolver a habilidade de } \\
\text { organização e planejamento operacional. }\end{array}$ \\
\hline Empresa Júnior & $\begin{array}{l}\text { Organização sem fins lucrativos formada por estudantes de graduação } \\
\text { com a finalidade de aliar teoria à prática, que contribui para a } \\
\text { propensão empreendedora dos mesmos }\end{array}$ \\
\hline Incubadoras & $\begin{array}{l}\text { Proporcionar ao estudante espaço de motivação e criação da nova } \\
\text { empresa, desenvolvendo múltiplas competências, tais como } \\
\text { habilidades de liderança, organizacionais, tomada de decisão e } \\
\text { compreender as etapas do ciclo de vida das empresas. Estimular o } \\
\text { fortalecimento da network com financiadores, fornecedores e clientes }\end{array}$ \\
\hline $\begin{array}{lll}\text { Aplicação } & \text { de } & \text { provas } \\
\text { dissertativas } & & \end{array}$ & $\begin{array}{l}\text { Testar os conhecimentos teóricos dos estudantes e sua habilidade de } \\
\text { comunicação escrita }\end{array}$ \\
\hline $\begin{array}{l}\text { Competição de planos de } \\
\text { negócios }\end{array}$ & $\begin{array}{l}\text { Desenvolver habilidades de comunicação, persuasão e estratégia. } \\
\text { Desenvolver capacidade de observação, percepção e aplicação de } \\
\text { melhorias no padrão de qualidade dos planos apresentados. Estimular } \\
\text { a abertura de empresas mediante os planos vencedores. }\end{array}$ \\
\hline Atendimento individualizado & $\begin{array}{l}\text { Desenvolver a habilidade de comunicação, interpretação, iniciativa e } \\
\text { resolubilidade. Aproximar o estudante do cotidiano real vivido nos } \\
\text { pequenos negócios }\end{array}$ \\
\hline Criação de produto & $\begin{array}{l}\text { Desenvolver habilidade de criatividade, persistência, inovação e senso } \\
\text { de avaliação. }\end{array}$ \\
\hline Filmes e vídeos & $\begin{array}{l}\text { Desenvolver a habilidade do pensamento crítico e analítico, } \\
\text { associando o contexto assistido com o conhecimento teórico. } \\
\text { Estimular a discussão em grupo e o debate de ideias }\end{array}$ \\
\hline
\end{tabular}


Projetos de Pesquisa e Extensão $\quad$ Projetos e atividades que possibilitem a construção da habilidade de aprender coletivamente, dialogar, construir conhecimentos e aplicar os conceitos junto à comunidade

Quadro 14: Principais Métodos, Técnicas e Recursos Pedagógicos no Ensino de Empreendedorismo Fonte: Adaptado de Rocha e Freitas (2014); Queiroz (2011) e Silva e Pena (2017)

Paralelo às práticas pedagógicas do ensino do empreendedorismo, tem-se os estudos no processo de avaliação destas práticas no sentido de se aferir a aprendizagem do aluno. A avaliação da aprendizagem do empreendedorismo entre estudantes de graduação tem sido conduzida por diferentes modelos que, em sua maioria, tentam medir o resultado dessa aprendizagem, relacionando-a com os desafios de empreender (ROCHA E FREITAS, 2014).

A participação do professor neste processo também se destaca. Segundo Friedlaender (2004), o papel do professor é primordial na orientação de como o aluno irá obter o conteúdo necessário para seu aprendizado. Neste contexto, o professor não pode ser mais o transmissor de informações, mas sim o facilitador e articulador do aprendizado, independentemente do nível de educação em que está inserido. Para o autor, "ensinar é orientar, estimular, relacionar mais do que simplesmente informar. Porém, só orienta aquele que conhece, que domina, que tem base teórica consistente e que sabe se comunicar, se atualizar-se sempre, saber aprender, saber trabalhar as informações que os alunos trazem, propiciando interação professor-aluno" (FRIEDLAENDER, 2004, p. 36).

Para Santa Rita et.al. (2008), o ensino do empreendedorismo tem se mostrado um grande instrumento de mudança no perfil sócio econômico brasileiro de todo recémformado, podendo aprimorar a distribuição de renda e alterar o nível de competitividade no mercado. Para tanto é necessário criar uma cultura empreendedora que possibilite uma nova postura dos profissionais e proponha uma reformulação no sistema de ensino superior. A nova função da universidade e de seus cursos, antes simplesmente pesquisar e formar recursos humanos, atualmente agrega ao dever de fomentar e induzir o empreendedorismo não só para seus estudantes, mas também nos seus trabalhos de pesquisa e desenvolvimento, tanto científico como tecnológico.

Lopes (2010) traz outros dados importantes. Com relação à ideia de o empreendedorismo ser uma disciplina que pode ser aprendida, a autora destaca os resultados do relatório da Conferência de Oslo da comissão Europeia de 2006. Nesse 
relatório constam dois estudos interessantes sobre resultados da educação empreendedora. No Green Paper on Entrepreneurship, há evidências de que pessoas que tiveram a oportunidade de serem expostas ao empreendedorismo por meio da família, dos amigos ou da educação mostravam-se mais inclinadas a considerar, com seriedade, a possibilidade de ser um empreendedor.

Já, o instituto de pesquisa do nordeste da Noruega mostrou em 2007, por meio de um estudo realizado junto às ações do programa de empresas "Young Enterprise", que a taxa de atividade empreendedora junto aos jovens participantes de 20 a 29 anos, foi de 15\%; maior do que a média da população geral europeia que é de $5 \%$ a $6 \%$. Conclui, portanto, que toda prática educativa orienta-se pelas finalidades educacionais, por isso é essencial definir o perfil desejado do educando, e delimitar as competências necessárias, as que darão a ele condições para realizar determinadas tarefas ou desafios.

Segundo Souza et.al (2004), a necessidade de desenvolver espírito crítico passa a ser um diferencial ao egresso de cursos de graduação de modo geral. Em um cenário, em que as novas tecnologias de produção e de informação são as ferramentas de busca para melhores resultados nas organizações, dominá-las passa a ser questão de ordem. Para responder à essas demandas, buscando novas estratégias institucionais e estruturas curriculares, além de alternativas metodológicas inovadoras, surgem movimentos de inserção da cultura empreendedora no contexto das universidades, com o propósito de direcionar seu processo de ensino-aprendizagem. Desse modo, achar um razoável caminho para padronizar programas e cursos para o ensino do empreendedorismo representa verdadeiro desafio aos estudiosos do tema (KURATKO, 2007; DOLABELA, 2008; KATZ, 2003; COAN, 2012; SANTA RITA, et.al 2008).

Diante dos estímulos à cultura empreendedora, para assegurar os avanços econômicos e sociais, atualmente discutem-se temas sobre como devem ser conduzidas as práticas educativas para desenvolver competências necessárias à atuação eficaz do empreendedor diante dos desafios estabelecidos (LOPES, 2010). Nesse cenário, há inúmeras iniciativas e práticas.

Convergindo com essa as ideias de Lopes (2010), Lucena e Centurión (2011) correlacionam o ensino do empreendedorismo com a filosofia de educação de Paulo Freire. 
Esta correlação traz um conjunto de associações das práticas da pedagogia freiriana como aporte ao ensino do empreendedorismo, apontando fatores que podem ser trabalhados para se criar um ambiente propício no processo de ensino. Para os autores:

\begin{abstract}
... a educação empreendedora enfatiza comportamentos e atitudes, envolvendo o desenvolvimento de potencialidades fundamentais em um âmbito maior que o fazer empresarial e o saber técnico científico, buscando na autorrealização a valorização do ser e da coletividade, fatores que convergem diretamente com a pedagogia proposta por Paulo Freire. Lançar um olhar empreendedor no cenário educacional de acordo com a visão freireana permite que os atores do sistema educacional, ou seja, os alunos, professores e gestores sejam estimulados para uma ação de forma mais reflexiva e visionária (LUCENA e CENTURIÓN, 2011, p. 01).
\end{abstract}

Lopes (2010) comenta que um novo corpo de conhecimento acadêmico deve ser formado para respaldar a educação empreendedora a partir das demandas identificadas, por isso hoje já se tem muita experiência acumulada nacional e internacionalmente. A disseminação dessas práticas promove uma cultura empreendedora no âmbito educacional e precisa ser adotada como alternativa para incutir na rotina das universidades, práticas pedagógicas que levem os alunos a desenvolverem comportamentos mais autônomos e independentes (VIEIRA, MELATTI e RIBEIRO 2011; FERNANDES, 2014; EUFRASIO e GOMES, 2012) e será melhor abordara no tópico seguinte.

\title{
2.8 Cultura Empreendedora nas IES
}

Mudar uma cultura não é fácil. Para Vieira, Melatti e Ribeiro (2011), cultura é uma resposta a uma série de ações coletivas que vão impregnando o comportamento das pessoas, passando a fazer parte do seu cotidiano. Para os autores, vários aspectos sociais, econômicos e comportamentais, ancorados em mudanças de ordem global, podem impactar, interferir ou mesmo criar novos comportamentos e ações de uma sociedade. Cultura, para Amorim (2018), está ligada a paradigmas, convenções, hábitos, aceitos e praticados por um grupo que entendem que aquilo é o correto, isto é, está convencionado, portanto, praticado e aceito por todos. Mudanças neste status quo podem não ser tão bem aceitas, seja pela sensação de deixar a chamada zona de conforto, seja pelo temor do desconhecido. Ainda para Amorim (2018), a cultura empreendedora, assim como, qualquer outra cultura, deve ser compreendida como fruto de hábitos, costumes, práticas e valores do meio em que se vive. 
A cultura empreendedora nas instituições de ensino é um tema bastante recente na própria literatura sobre empreendedorismo e pode-se dizer que é fundamental para o desenvolvimento profissional e econômico de uma região (FRIEDLAENDER, 2004), uma vez que é caracterizada pelo perfil empreendedor, o que a torna capaz de mudar ou transformar a realidade de determinada região por meio da educação empreendedora. Uma comunidade ou região que possua esta cultura tende a ser fortalecida, pois consegue visualizar e aproveitar novas oportunidades (Souza, et.al, 2004). Além disso, por meio desse ambiente inovador tem a possibilidade de trabalhar baseando-se em estratégias e planejamento, que são os alicerces da cultura empreendedora, diminuindo as incertezas nas oportunidades de negócios e gerando uma forte vantagem competitiva para os grupos que a possuem (SCHIMIDT e DREHER, 2008).

Ainda para os autores, desde o início da era do empreendedorismo moderno, esperava-se que o contexto cultural tivesse um impacto considerável no seu desenvolvimento. A tendência e o contexto para o empreendedorismo difere entre as sociedades, porque a cultura que norteia as características dos empreendedores difere de lugar para lugar e essa é uma questão essencial, pois o ser humano não nasce empreendedor, ele desenvolve essa habilidade a partir da interpretação do meio em que vive, e o ambiente, tanto a época quanto o lugar, é um influenciador dessa tendência.

Assim, percebemos que a ideia da cultura empreendedora surge de ações de fomento à observação, percepção e análise de tendências, na sociedade, nos hábitos sociais e de consumo. Nesse sentido, o empreendedorismo pode ser uma forma de pensar e agir sobre oportunidades. Trata-se de um conceito muito mais amplo do que o simples ato de abrir e fechar empresas destinadas a garantir a subsistência das pessoas atingidas pela escassez de vagas no mercado de empregos. Surge como uma forma de mudar a realidade da falta de emprego e da limitada visão e percepção que as pessoas têm sobre as possibilidades de inserção no mercado de trabalho.

A cultura empreendedora promove a emergência de novas oportunidades, os meios de capitalizá-las e a criação de estrutura adequada para seu aproveitamento. A estratégia e o planejamento são os alicerces da cultura empreendedora, para diminuir as incertezas nas 
oportunidades de negócios, o que está em conformidade com a atitude do empreendedor de sempre calcular o risco de maneira premeditada (SCHIMIDT e DREHER, 2008).

A educação de um modo geral impacta e é impactada por essas transformações culturais. As universidades, inseridas nesse contexto, passam a viver sob o impacto de um processo de transição não só de seu contexto interno como externo. Para as autoras, esta instituição universidade já passou por várias transformações importantes, que vêm desde o século XII com seu modelo medieval e institucionalizada sob três fatores, formação teológica, jurídica e filosófica, atendendo a uma sociedade baseada numa visão católica, que exercia um poder político e autocrático. A partir do século XV, a universidade passa por uma nova fase, chamada universidade renascentista, que abre espaço para o humanismo e as ciências, fatores da universidade moderna do século XIX. Surge então a universidade pública em meados do século XIX, resultante de um movimento capitaneado pelas universidades de Berlim e de Londres, as quais deram as bases para as relações "universidade, sociedade, conhecimento e poder". Atualmente, as bases são as mesmas, inseridas, no entanto num contexto produtivo e mercadológico muito mais presente.

Vemos as universidades hoje, desafiadas a adaptarem-se às suas múltiplas tarefas de formação, pesquisa e difusão de cultura e informação em contexto caracterizado pela democratização, revolução tecnológica, mudanças nas relações de trabalho e necessidade de estabelecer vínculos com o mercado (SOUZA, et.al, 2004).

Na União Europeia, segundo Henrique e Cunha (2006), há um consenso de que a prosperidade econômica depende da criação de negócios que estejam enraizados na economia local e isso pode ser caracterizado como uma promoção de cultura empreendedora. No Reino Unido, os responsáveis pela política de desenvolvimento veem no ensino do empreendedorismo e na cultura empreendedora, a solução mais pragmática para a crescente gama de desafios socioeconômico e políticos atuais. A redução de barreiras de comércio e a realidade da sua moeda, o Euro, junto com os avanços em telecomunicações, tecnologia e transporte possibilitaram criar maiores oportunidades assim como também mais incerteza no mundo (SOUZA, et.al, 2004).

Num contexto brasileiro, Dornelas (2013) ressalta a existência de fortes motivos que justificam a promoção de uma cultura empreendedora como sendo um catalisador da 
expansão do empreendedorismo, como: grandes mudanças nas relações de trabalho; a não adequação do ensino tradicional para a formação de empreendedores; relações universidade-empresa ainda são incipientes no Brasil; insuficiente percepção da importância das pequenas e médias empresas para o desenvolvimento econômico regional; ética como preocupação de ensino do empreendedorismo; necessidade das organizações por empregados com alto grau de empreendedorismo e cultura das grandes corporações, que predomina no ensino profissionalizante e universitário.

Dornelas (2013) corrobora ao dizer que diversas pesquisas têm demonstrado que os países que apoiam e incentivam a cultura empreendedora tornam-se mais dinâmicos, desenvolvendo crescimento econômico e diminuindo as taxas de desemprego. Em tempo, o empreendedorismo, estimulado pelo ensino e cultura, pode ser o motor do crescimento da economia local e da geração de empregos. Ainda segundo o autor, a formação empreendedora tem como princípios: aprender a compreender o mundo, analisando e definindo as diferentes facetas do seu contexto individual e institucional; comunicação e colaboração em contexto competitivo; raciocínio criativo e resolução de problemas encarando a vida em uma perspectiva criativa; domínio pessoal, processo no qual é desenvolvido o autoconhecimento e o auto desenvolvimento; pensamento sistêmico, possibilitando clareza na percepção do todo e das relações entre as partes; liderança, tratada muito mais como uma característica adquirida, envolvendo duas direções, à vontade e a determinação e o conhecimento acumulado em um dado setor, incluindo a aquisição de uma série de competências distintas.

Souza et.al (2004) sugerem, portanto, o desenvolvimento de estratégias que visem incentivar a utilização com mais frequência de técnicas voltadas para o desenvolvimento de competências atitudinais e cognitivas do futuro empreendedor, e, levando em conta que a formação empreendedora baseia-se na imaginação, criatividade, associadas à inovação, passa a ser importante criar um ambiente favorável ao empreendedorismo, no qual estejam incluídos espaços de discussão, reflexão e um sistema de suporte que incentive o jovem empreendedor.

Por conta disso, ainda segundo os autores, está havendo um movimento quase que global de países capacitando pessoas a empreenderem, inclusive o Brasil, com a inserção de 
disciplinas deste tema nas grades dos cursos em universidades, cursos de capacitação profissionalizante, palestras e oficinas, fomentando uma rotina empreendedora no cotidiano dos estudantes. Cada vez mais as empresas e sociedades de todos os portes estão percebendo a importância e a necessidade do comportamento empreendedor e do desenvolvimento e fomento da cultura empreendedora, uma vez que estes são componentes essenciais para a sobrevivência e o sucesso das organizações num mercado com tanta competição, com mudanças tão rápidas e constantes. Nesse contexto, é fundamental que essa cultura esteja enraizada nas pessoas por meio da sua formação, acadêmica e profissional (SCHIMIDT e DREHER, 2008).

Sendo assim, novos paradigmas vêm sendo assumidos por diversos educadores responsáveis pelo processo de ensino-aprendizagem, com a adoção de práticas conscientizadoras, em que o educando possa assumir o papel de sujeito ativo e criador, indo além de ler e escrever, aprendendo a pensar, criticamente, ganhando autonomia e promovendo seu empoderamento.

\subsection{O Ensino do Empreendedorismo na saúde}

Como já foi discutido, independentemente da área, o empreendedorismo é considerado forte propulsor de alavancagem dos setores da economia de modo geral e também por auxiliar no êxito das profissões. O profissional recém-formado, seja da área de saúde, negócios, exatas, humanas, etc., precisará conhecer o segmento em que se está inserindo, buscando identificar possibilidades para sua inserção no mercado de trabalho, seja como colaborador, seja como empreendedor. A este último cabe possuir conhecimentos, habilidades e atitudes que lhes permitem uma inserção no mercado com chances de sucesso (HENRIQUE E CUNHA, 2006).

A saúde, tida como um recurso para a vida e não como um fim dela, centra-se na pessoa e na comunidade, sendo assim, devem ser capazes de identificar necessidades, definir prioridades e planear e implementar estratégias condizentes com essas necessidades à saúde. Dessa forma, os profissionais de saúde devem agir com protagonismo, sendo 
prioritário o desenvolvimento de competências individuais e visão coletiva, características condizentes com o que a teoria denomina de perfil empreendedor (FEIO e OLIVEIRA, 2015).

Como afirma Terrim et.al (2015), o ensino do empreendedorismo na área da saúde não é um tema muito comum, devido ao fato de serem cursos densos em termos de conteúdo específico e também pela importância que é dada ao desenvolvimento de competências técnicas. Para os autores, o termo está diretamente relacionado à realização de uma tarefa. Quando aplicado a uma atividade empresarial, engloba-se um conjunto de ações que geram resultados superior ao investimento inicial. Como consequência, aumentase o patrimônio, gera-se empregos e proporciona-se um benefício social que, na área da saúde, implica na melhora da qualidade de vida e saúde do público atendido. O olhar do empreendedor na área da saúde está não somente no tratamento de doenças, mas em buscar soluções para problemas cotidianos que possam ser solucionados com um produto ou serviço inovador.

Para Nakao (2016), as profissões da área da saúde, devem preparar o profissional para uma versão mais autônoma de suas atividades, como, empreender em uma atividade própria. Egressos em odontologia, terapia ocupacional, educação física, fonoaudiologia, medicina, enfermagem, nutrição, fisioterapia, medicina veterinária, farmácia, etc., tendem a seguir por este caminho. No entanto para isso, precisarão possuir prévios conhecimentos sobre o mercado em que irão atuar, base concorrencial, noções de finanças sobre retorno do investimento, dentre outras. Boa parte dessas habilidades são trabalhadas num escopo chamado de plano de negócios ${ }^{17}$, desenvolvido por meio de conteúdos contemplados em disciplinas de empreendedorismo.

As ideias de Nakao (2016) convergem com o pensamento de Terrim et.al (2015), ao afirmar que o empreendedorismo para a área da saúde representa um conjunto de comportamentos e ideias que levam à inovação na criação ou aprimoramento de produtos e serviços voltados ao setor. A cultura de ações empreendedoras pode gerar transformações pessoais e atitudinais que promovam impactos profundos no mercado e na sociedade.

\footnotetext{
${ }^{17}$ Plano de negócios trata-se de um documento, elaborado com objetivos, cronogramas, detalhamento de ações, etc., que descreve o passo a passo para a concretização de um projeto, normalmente voltado a escopo de projeto empresarial e que por meio dele, tem-se a fotografia de todas as ações prévias para a concepção do negócio (CHIAVENATO, 2006)
} 
Parafraseando o filósofo Nicolau Maquiavel, "empreendedores são aqueles que entendem que há uma pequena diferença entre obstáculos e oportunidades e são capazes de transformar ambos em vantagem".

Nakao (2016) ainda traz algumas peculiaridades da área da saúde. Para o autor, a área da saúde possui um marketing chamado de demanda negativa, por ser entendido como um serviço que as pessoas evitam, por razões óbvias (ninguém quer estar doente, ninguém quer estar acamado, ninguém quer estar na condição de necessitar de alguma assistência médica, pelo contrário, as pessoas querem estar saudáveis). Esta visão de negócio pode ser um fator negativo para muitos, mas para um empreendedor, ele é tido como uma oportunidade, tendo em vista o tipo de visão que o profissional tende a desenvolver, algo voltado para análises de janelas de oportunidades. Apesar das pessoas não desejarem a doença, muitas vezes ela é inerente às vontades e desejos pois demandam de circunstâncias alheias à nossa vontade e portanto, precisam ser gerenciadas, inclusive na coletividade (TAVARES, 2003).

Outras peculiaridades da área da saúde são: alta regulamentação: setores da saúde precisam obedecer a uma séria de normas e procedimentos legais, atendimento ao código de ética da categoria, ligados à conselhos; regras estabelecidas em documentos informacionais conforme normas restritivas do marketing médico como por exemplo, o caráter educativo de informes, propaganda enganosa, informações falsas, etc.; licenças urbanas e conformidade com regras de vigilância sanitária (FERNANDES, 2005).

Dados do IBGE ${ }^{18}$ mostram que, são mais de 6.000 hospitais no Brasil para atender a uma população de mais de 200.000 pessoas, apontado como o 8 maior do mundo e tendo o SUS - Sistema único de Saúde, o provedor de $80 \%$ dos atendimentos e $20 \%$ na rede privada (IBGE, 2018). Vê-se que a área da saúde compreende uma ampla gama de serviços e busca de soluções, que atendem desde necessidades básicas à projetos de melhoria na qualidade de vida das pessoas. Ainda segundo o instituto, nos últimos anos, o Brasil vem apresentando um novo padrão demográfico que se caracteriza pela redução da taxa de crescimento populacional e por transformações profundas na composição de sua estrutura etária, com um significativo aumento do contingente de idosos. Fato este que tem ancorado vários

18 O IBGE se estabelece como fornecedor de dados e informações do País, que respondem às necessidades dos mais variados segmentos da sociedade civil, bem como dos órgãos das esferas Governamentais Federal, Estadual e Municipal (BOTTONI et.al, 2019). 
estudos por parte das agências, institutos e governo no sentido de promoverem soluções para esse contingente de pessoas, a chamada $3^{a}$ idade. Dados assim, podem ser a fonte para uma mudança no rumo das inovações, voltadas para especificidades desse idoso e de suas necessidades.

Outro dado interessante sobre o contexto social, que faz menção às demandas da saúde pode ser extraído do livro Homo Deus: Uma breve história do amanhã do escritor Yuval Noah Harari, professor israelense que traz uma narrativa sobre os impactos das mudanças de comportamento para o século XXI. O autor traz duas estatísticas bastante interessantes e que estão intrinsecamente relacionadas com o tema deste trabalho. A primeira delas diz que: “a metade da humanidade estará com excesso de peso em 2030", e a segunda estatística diz que,

Em 2012, aproximadamente 56 milhões de pessoas morreram no mundo inteiro; 620 mil morreram em razão da violência humana (guerras mataram 120 mil pessoas, o crime matou outras 500 mil). Em contrapartida, 800 mil morreram de suicídio, e 1,5 milhão morreram de diabetes. O açúcar é mais perigoso que a pólvora (HARARI, 2016, p. 75).

Há de se refletir sobre tais dados, que merece toda atenção, primariamente como cidadão de mundo, mas também voltar os olhos para a questão da saúde no contexto global e o que os profissionais da saúde podem (e devem) fazer, criar, propor, em termos de soluções que atendam a essas questões que estão substancialmente inseridas no cotidiano da profissão dos especialistas em saúde. O que para muitos, pode ser visto como um problema, para um empreendedor, pode ser visto como uma oportunidade (BAUR et.al, 2016). Para os autores, os conhecimentos e habilidades empreendedoras não surgem de maneira espontânea no profissional. A participação das universidades nas formações mais abrangentes para os alunos da saúde, é fundamental para estimular o espírito empreendedor. As habilidades do ser empreendedor não se limitam apenas a gerenciar ou a ser dono de uma empresa, mas estão relacionadas à capacidade de liderança e de iniciativa, através do sujeito inovador. A atividade inovadora envolve o trabalho com as situações desconhecidas e esta é uma característica do cotidiano dos profissionais da saúde.

Nota-se, portanto, ser uma área que guarda algumas especificidades e que precisam ser trabalhadas na formação do profissional. Dentre as características específicas da saúde, tem-se as características sociais trazidas pela normalização dos cursos da saúde, chamada de 
Diretrizes curriculares nacionais, já citadas anteriormente e onde citam: gestão do cuidado, valorização da vida, tomada de decisões, comunicação e liderança, ou seja, habilidades pessoais, voltadas à inteligência emocional, também chamadas, segundo Terrim et.al (2015) de soft skills, e que, juntas às habilidades técnicas fazem do profissional uma pessoa diferenciada.

Buscando compreender o contexto do ensino do empreendedorismo nos cursos da área da saúde, mais especificamente em um Campus da Universidade de São Paulo, foi feito um levantamento documental junto às matrizes curriculares e respectivos planos de ensino das disciplinas dos 11 cursos da área da saúde, para identificar quais cursos possuem disciplinas voltadas ao empreendedorismo.

\subsection{Onsino do Empreendedorismo na Saúde: Uma Análise Documental}

Os resultados preliminares desta pesquisa serviram de base para formar um panorama dos cursos da área da saúde que possuem em suas matrizes curriculares, disciplinas de empreendedorismo ou da área de gestão e negócios que também poderiam possuir conteúdos sobre empreendedorismo em seu planejamento. Esta etapa da pesquisa subsidia a realização das outras fases da investigação.

As Diretrizes Curriculares Nacionais (DCN's), documentos que regem as atividades didáticas das instituições de ensino superior sobre determinada área de conhecimento, também discorrem sobre a necessidade e a importância dos aspectos do empreendedorismo na formação dos profissionais de saúde. O profissional deve estar apto para a vida empreendedora (BAUR et.al, 2016, p. 80), “a própria visão de multidisciplinaridade pertence aos princípios do empreendedorismo. Os empreendedores de maneira geral sabem que o êxito e o sucesso dependem de uma equipe competente, motivada para implantar ideias e desafios".

As DCN's estão dispostas em dois pareceres do INEP, na página do referido instituto, pareceres aprovados pelo Conselho Nacional de Educação - CNE, (Parecer CNE/CES no 1.210/2001, aprovado em 12 de setembro de 2001, e Parecer CNE/CES № 1.133/2001, aprovado em 7 de agosto de 2001), disponíveis no portal do Ministério da Educação e Cultura 
(MEC), citam em seu item 2 - denominado de Competências e Habilidades, o empreendedorismo como uma das competências necessárias ao perfil do egresso dos cursos da saúde, conforme trecho a seguir:

\section{Competências Gerais (DCNs):}

- Atenção à saúde: os profissionais de saúde, dentro de seu âmbito profissional, devem estar aptos a desenvolver ações de prevenção, promoção, proteção e reabilitação da saúde, tanto em nível individual quanto coletivo. Cada profissional deve assegurar que sua prática seja realizada de forma integrada e contínua com as demais instâncias do sistema de saúde, sendo capaz de pensar criticamente, de analisar os problemas da sociedade e de procurar soluções para os mesmos. Os profissionais devem realizar seus serviços dentro dos mais altos padrões de qualidade e dos princípios da ética/bioética, tendo em conta que a responsabilidade da atenção à saúde não se encerra com o ato técnico, mas sim, com a resolução do problema de saúde, tanto em nível individual como coletivo;

- Tomada de decisões: o trabalho dos profissionais de saúde deve estar fundamentado na capacidade de tomar decisões visando o uso apropriado, eficácia e custo efetividade, da força de trabalho, de medicamentos, de equipamentos, de procedimentos e de práticas. Para este fim, os mesmos devem possuir competências e habilidades para avaliar, sistematizar e decidir as condutas mais adequadas, baseadas em evidências científicas;

- Comunicação: os profissionais de saúde devem ser acessíveis e devem manter a confidencialidade das informações a eles confiadas, na interação com outros profissionais de saúde e o público em geral. A comunicação envolve comunicação verbal, não-verbal e habilidades de escrita e leitura; o domínio de, pelo menos, uma língua estrangeira e de tecnologias de comunicação e informação;

- Liderança: no trabalho em equipe multiprofissional, os profissionais de saúde deverão estar aptos a assumir posições de liderança, sempre tendo em vista o bemestar da comunidade. A liderança envolve compromisso, responsabilidade, empatia, habilidade para tomada de decisões, comunicação e gerenciamento de forma efetiva e eficaz;

- Administração e gerenciamento: os profissionais devem estar aptos a tomar iniciativa, fazer o gerenciamento e administração tanto da força de trabalho, dos recursos físicos e materiais e de informação, da mesma forma que devem estar aptos a ser empreendedores, gestores, empregadores ou lideranças na equipe de saúde (grifo nosso);

- Educação permanente: os profissionais devem ser capazes de aprender continuamente, tanto na sua formação, quanto na sua prática. Desta forma, os profissionais de saúde devem aprender a aprender e ter responsabilidade e compromisso com a sua educação e o treinamento/estágios das futuras gerações de profissionais, proporcionando condições para que haja benefício mútuo entre os futuros profissionais e os profissionais dos serviços, inclusive, estimulando e desenvolvendo a mobilidade acadêmico/profissional, a formação e a cooperação através de redes nacionais e internacionais. 
A partir desta etapa da pesquisa documental, foi possível compreender o cenário do ensino do empreendedorismo na área da saúde para assim, num segundo momento, estruturar um problema de pesquisa e partir para a pesquisa de campo com os cursos pesquisados. Os dados foram obtidos por meio dessa pesquisa de cunho documental, um levantamento e análise das matrizes curriculares dos cursos da área da saúde, oferecidos pela Universidade de São Paulo - USP. As matrizes foram obtidas pelo endereço eletrônico http://www5.usp.br/ensino/graduacao/cursos-oferecidos/.

O complexo da Universidade de São Paulo oferece 86 cursos de graduação, sendo 19 cursos voltados à área da saúde. Desses 19 cursos, 11 são oferecidos pela USP Campus Ribeirão Preto e, portanto, foram os cursos analisados com base em suas matrizes curriculares, planos de ensino disciplinar e respectivos conteúdos programáticos.

O quadro a seguir objetiva sintetizar os cursos por meio das grandes áreas de humanas, exatas e biológicas segundo tipificação do Ministério da Educação. 


\begin{tabular}{|c|c|c|}
\hline \multicolumn{3}{|c|}{$\begin{array}{l}\text { CURSOS OFERECIDOS PELA USP SEPARADOS } \\
\text { SEGUNDO MEC }\end{array}$} \\
\hline Área Humanas & Área Exatas & Área Biológicas \\
\hline Administração & Astronomia & Ciências biológicas \\
\hline Arquitetura e urbanismo & Ciências agrárias & Biomedicina - Biotecnologia \\
\hline Artes cênicas & Ciências da Computação & Biomedicina - Ciências Básicas \\
\hline Artes visuais & Ciências Exatas & Educação Física e Esporte \\
\hline Audiovisual & Engenharia Aeronáutica & Ciências Físicas e Biomoleculares \\
\hline Biblioteconomia & Engenharia Agronômica & Enfermagem \\
\hline Ciências Atuariais & Engenharia Ambiental & Farmácia-bioquímica \\
\hline Ciências da Natureza & Engenharia Bioquímica & Física Médica \\
\hline Ciências dos Alimentos & Engenharia Civil & Fisioterapia \\
\hline Ciências Sociais & Engenharia de Alimentos & Fonoaudiologia \\
\hline Design & Engenharia de Biossistemas & Gerontologia \\
\hline Direito & Engenharia de Computação & Medicina \\
\hline Economia & Engenharia de Materiais & Medicina Veterinária \\
\hline Editoração & Engenharia de Minas & Nutrição \\
\hline Filosofia & Engenharia de Petróleo & Nutrição e Metabolismo \\
\hline $\begin{array}{l}\text { Geociências e Educação } \\
\text { ambiental }\end{array}$ & Engenharia de Produção & Odontologia \\
\hline Geografia & Engenharia Elétrica & Saúde Pública \\
\hline Gestão Ambiental & Engenharia Física & Terapia Ocupacional \\
\hline Gestão de Políticas Públicas & Engenharia Florestal & Zootecnia \\
\hline História & Engenharia Mecânica & \\
\hline Jornalismo & Engenharia Mecatrônica & \\
\hline Lazer e Turismo & Engenharia Naval & \\
\hline Letras & Engenharia Química & \\
\hline Marketing & Estatística & \\
\hline Meteorologia & Física & \\
\hline Música & Física Computacional & \\
\hline Pedagogia & Geofísica & \\
\hline Psicologia & Geologia & \\
\hline Publicidade e Propaganda & Informática Biomédica & \\
\hline Relações Internacionais & Matemática & \\
\hline Relações Públicas & Oceanografia & \\
\hline Têxtil e Moda & Química & \\
\hline Turismo & Sistemas de Informação & \\
\hline
\end{tabular}

Quadro 15: Classificação dos cursos oferecidos pela USP, com base nas áreas de conhecimento Fonte: Portal da USP - http://www5.usp.br/ensino/graduacao/cursos-oferecidos/areas 
Para a etapa de refinamento, foram analisadas todas as páginas dos 11 cursos já identificados, como sendo da área da saúde, buscando os cursos oferecidos pelo Campus de Ribeirão Preto/SP. A imagem a seguir objetiva ilustrar como as páginas disponibilizavam as informações dos cursos e em quais campi são oferecidos. Com base nesta informação, o refinamento foi realizado:

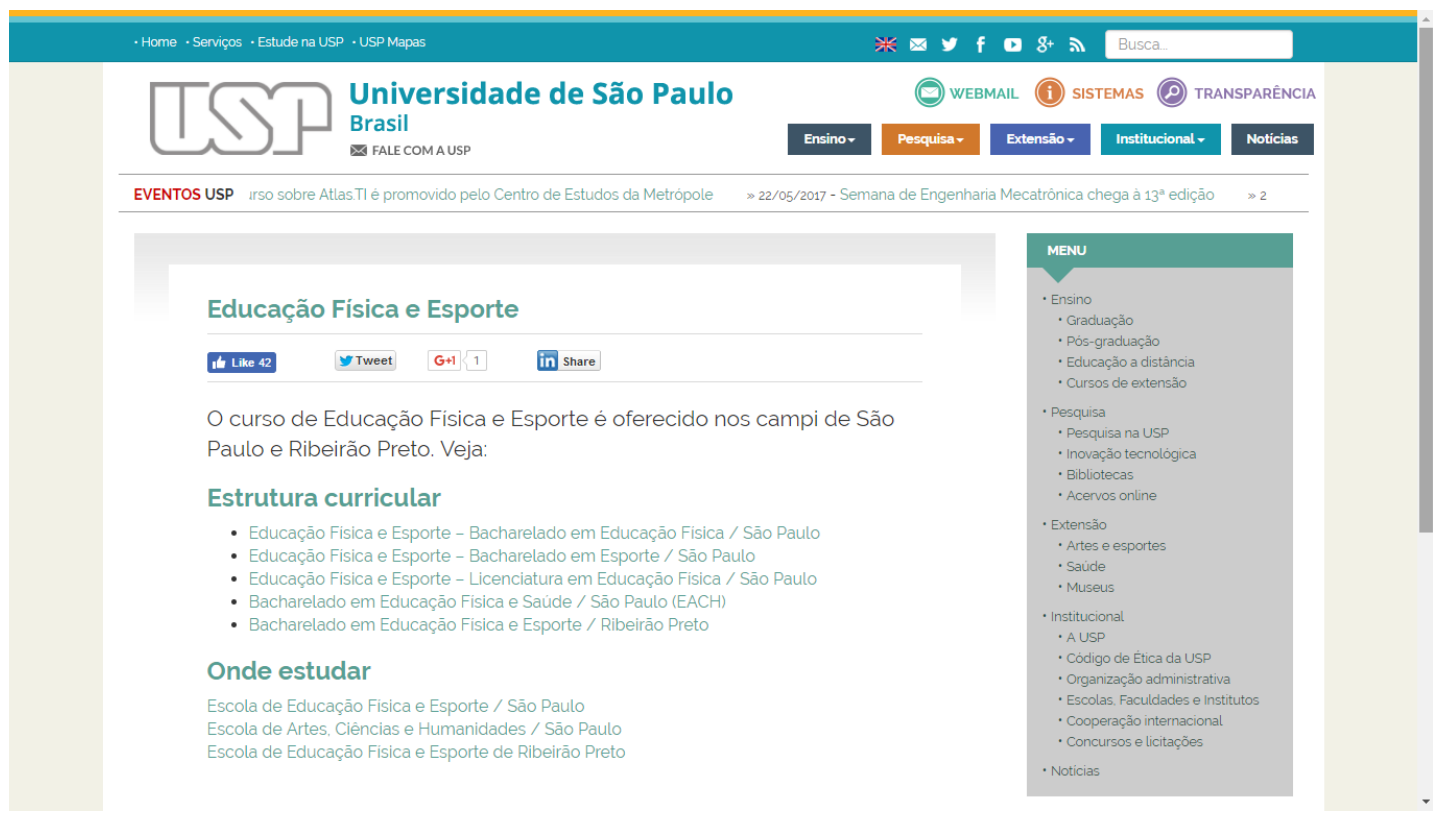

Figura 2: Página da Universidade, como exemplo das informações de um curso e campi ofertado Fonte: http://www5.usp.br/ensino/graduacao/cursos-oferecidos/educacao-fisica-e-esporte/

Outro exemplo, agora da página do curso de Enfermagem - EERP/USP:

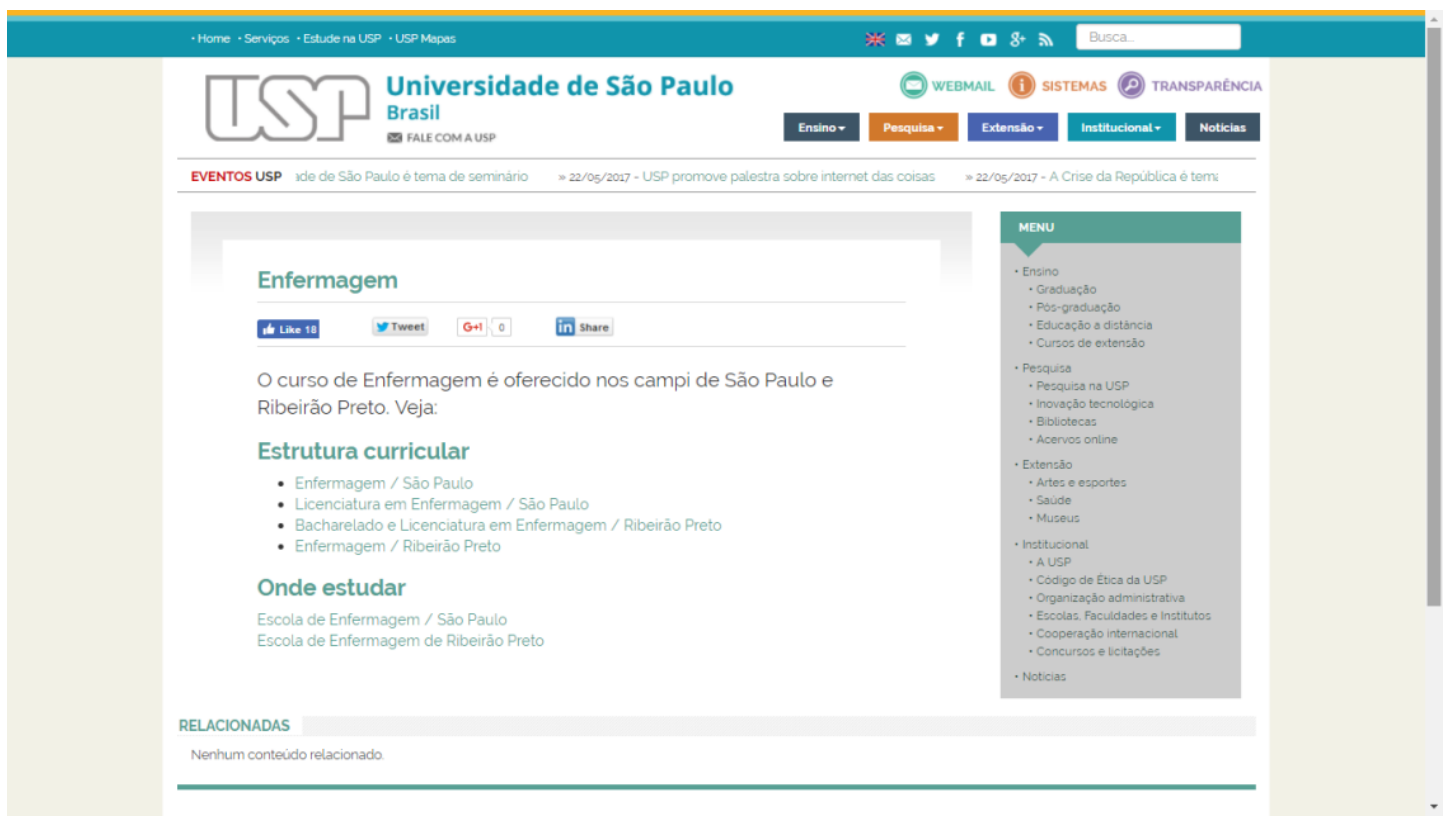

Figura 3: Página da Universidade, como exemplo das informações de um curso e campi ofertado Fonte: http://www5.usp.br/ensino/graduacao/cursos-oferecidos/educacao-fisica-e-esporte/ 
Para o refinamento da busca por temas de empreendedorismo nas matrizes curriculares, utilizou-se o próprio portal da USP, por meio dos hiperlinks gerados pelos nomes dos cursos, conforme quadro a seguir:

\begin{tabular}{|c|c|}
\hline $\begin{array}{l}\text { Cursos da área da saúde } \\
\text { oferecidos pela universidade de } \\
\text { São Paulo-USP }\end{array}$ & Respectivos endereços eletrônicos \\
\hline $\begin{array}{l}\text { Ciências Biomédicas - Ênfase em } \\
\text { Biotecnologia em Saúde }\end{array}$ & $\begin{array}{c}\text { https://uspdigital.usp.br/jupiterweb/listarGradeCurricular?codcg }=17 \& c \\
\text { odcur }=17500 \& \text { codhab }=300 \& \text { tipo }=N\end{array}$ \\
\hline $\begin{array}{l}\text { Ciências Biomédicas - Ênfase em } \\
\text { Ciências Básicas da Saúde }\end{array}$ & $\begin{array}{c}\text { https://uspdigital.usp.br/jupiterweb/listarGradeCurricular?codcg=17\&c } \\
\text { odcur }=17500 \& \text { codhab }=200 \& \text { tipo }=N\end{array}$ \\
\hline Educação Física e Esporte & $\begin{array}{l}\text { http://www5.usp.br/ensino/graduacao/cursos-oferecidos/educacao- } \\
\text { fisica-e-esporte/ }\end{array}$ \\
\hline $\begin{array}{l}\text { Educação Física e Esporte - Ciclo } \\
\text { Básico }\end{array}$ & $\begin{array}{c}\text { https://uspdigital.usp.br/jupiterweb/listarGradeCurricular?codcg }=98 \& \mathrm{c} \\
\text { odcur }=98001 \& \text { codhab }=100 \& \text { tipo }=\mathrm{N}\end{array}$ \\
\hline $\begin{array}{l}\text { Educação Física e Esporte - Ênfase } \\
\text { em Educação Física e Saúde }\end{array}$ & $\begin{array}{c}\text { https://uspdigital.usp.br/jupiterweb/listarGradeCurricular?codcg }=98 \& \text { c } \\
\text { odcur }=98001 \& \text { codhab }=200 \& \text { tipo }=N\end{array}$ \\
\hline $\begin{array}{l}\text { Educação Física e Esporte - Ênfase } \\
\text { em Esporte }\end{array}$ & $\begin{array}{c}\text { https://uspdigital.usp.br/jupiterweb/listarGradeCurricular?codcg=98\&c } \\
\text { odcur }=98001 \& \text { codhab }=300 \& \text { tipo }=\mathrm{N}\end{array}$ \\
\hline $\begin{array}{l}\text { Enfermagem - Bacharelado ( } 8 \\
\text { semestres) }\end{array}$ & $\begin{array}{c}\text { https://uspdigital.usp.br/jupiterweb/listarGradeCurricular?codcg }=22 \& c \\
\text { odcur }=22013 \& \text { codhab }=0 \& \text { tipo }=N\end{array}$ \\
\hline $\begin{array}{l}\text { Enfermagem - Bacharelado e } \\
\text { Licenciatura }\end{array}$ & $\begin{array}{c}\text { https://uspdigital.usp.br/jupiterweb/listarGradeCurricular?codcg }=22 \& c \\
\text { odcur=22100\&codhab }=4 \& \text { tipo }=N\end{array}$ \\
\hline $\begin{array}{l}\text { Farmácia-bioquímica - } \\
\text { Modalidade Fármaco e } \\
\text { Medicamento - noturno }\end{array}$ & $\begin{array}{l}\text { https://uspdigital.usp.br/jupiterweb/listarGradeCurricular?codcg=60\&c } \\
\text { odcur=60011\&codhab=304\&tipo=N\&print=true } \\
\text { O curso não possui matriz curricular e a página está datada de } \\
\text { 01/01/2008, o que induz a crer que o curso não está mais sendo oferecido }\end{array}$ \\
\hline Farmácia-bioquímica - Integral & $\begin{array}{c}\text { https://uspdigital.usp.br/jupiterweb/listarGradeCurricular?codcg=60\&c } \\
\text { odcur }=60012 \& \text { codhab }=0 \& \text { tipo }=N\end{array}$ \\
\hline Farmácia-bioquímica - Noturno & $\begin{array}{l}\text { https://uspdigital.usp.br/jupiterweb/listarGradeCurricular?codcg }=60 \& c \\
\text { odcur=60012\&codhab=4\&tipo=N\&print=true }\end{array}$ \\
\hline Fisioterapia & $\begin{array}{c}\text { https://uspdigital.usp.br/jupiterweb/listarGradeCurricular?codcg }=17 \& \mathrm{c} \\
\text { odcur }=17100 \& \text { codhab }=4 \& \text { tipo }=\mathrm{N}\end{array}$ \\
\hline Fonoaudiologia & $\begin{array}{c}\text { https://uspdigital.usp.br/jupiterweb/listarGradeCurricular?codcg=17\&c } \\
\text { odcur=17300\&codhab=1\&tipo=N } \\
\text { Como o link do Campus Ribeirão Preto estava desatualizado (sem } \\
\text { matriz postada), foi analisado link do Campus São Paulo, por meio do link: } \\
\text { https://uspdigital.usp.br/jupiterweb/listarGradeCurricular?codcg=5\&co } \\
\text { dcur=5063\&codhab=0\&tipo=N }\end{array}$ \\
\hline Gerontologia & $\begin{array}{l}\text { http://www5.usp.br/ensino/graduacao/cursos- } \\
\text { oferecidos/gerontologia/ } \\
\text { Curso é oferecido apenas Campus USP São Paulo }\end{array}$ \\
\hline Medicina & $\begin{array}{c}\text { https://uspdigital.usp.br/jupiterweb/listarGradeCurricular?codcg }=17 \& \mathrm{c} \\
\text { odcur=17050\&codhab=0\&tipo=N }\end{array}$ \\
\hline Nutrição & $\begin{array}{l}\text { http://www5.usp.br/ensino/graduacao/cursos-oferecidos/nutricao/ } \\
\text { Curso é oferecido apenas Campus USP São Paulo }\end{array}$ \\
\hline Odontologia & $\begin{array}{l}\text { https://uspdigital.usp.br/jupiterweb/listarGradeCurricular?codcg=58\&c } \\
\text { odcur=58011\&codhab=0\&tipo=N } \\
\text { O link acima não disponibilizava a matriz do curso de odontologia pela } \\
\text { Faculdade de Ribeirão Preto, assim, foram feitas outras buscas pela internet, } \\
\text { chegando ao seguinte link: } \\
\text { https://uspdigital.usp.br/jupiterweb/listarGradeCurricular?codcg=58\&c } \\
\text { odcur=58012\&codhab=0\&tipo=V\&print=true }\end{array}$ \\
\hline Psicologia - Bacharelado & $\begin{array}{l}\text { https://uspdigital.usp.br/jupiterweb/listarGradeCurricular?codcg }=59 \& \mathrm{c} \\
\text { odcur=59030\&codhab=100\&tipo=N\&print=true }\end{array}$ \\
\hline
\end{tabular}




\begin{tabular}{|c|c|}
\hline Psicologia & $\begin{array}{c}\text { https://uspdigital.usp.br/jupiterweb/listarGradeCurricular?codcg }=59 \& \mathrm{c} \\
\text { odcur }=59030 \& \operatorname{codhab}=300 \& \text { tipo }=\mathrm{N}\end{array}$ \\
\hline Terapia Ocupacional & $\begin{array}{c}\text { https://uspdigital.usp.br/jupiterweb/listarGradeCurricular?codcg }=17 \& \mathrm{c} \\
\text { odcur }=17200 \& \operatorname{codhab}=4 \& \text { tipo }=\mathrm{N}\end{array}$ \\
\hline
\end{tabular}

Quadro 16: Cursos da área da saúde e seus respectivos links de acesso às matrizes curriculares

Fonte: elaborado pela autora

Por meio de pesquisa na plataforma da Universidade de São Paulo-USP, constatou-se que, dos 11 cursos da área da saúde analisados, oferecidos pelo Campus Ribeirão Preto-SP., nenhum curso possui disciplina denominada empreendedorismo ou termo correlato (empreendedorismo, perfil empreendedor, cultura empreendedora) em suas matrizes curriculares, considerando as disciplinas eletivas, ou seja, mínimas ou obrigatórias. Também não foi identificado nenhuma disciplina que tenha conteúdos sobre empreendedorismo em seus conteúdos programáticos. Como disciplina optativa, o curso de enfermagem passou a incorporar a disciplina Empreendedorismo e Inovação em Saúde, a partir de 01.01.2018.

Identificou-se também que, desses 11 cursos da área da saúde, todos possuem disciplinas voltadas às áreas de gestão/administração e desses 11, 6 possuem conteúdos sobre empreendedorismo em seus conteúdos programáticos.

Os cursos analisados foram: enfermagem, medicina, fisioterapia, terapia ocupacional, ciências biomédicas (ênfase em biotecnologia em saúde e ênfase em ciências básicas da saúde), educação física, farmácia, fonoaudiologia, gerontologia, nutrição e saúde pública.

O quadro a seguir traz o detalhamento das informações das disciplinas identificadas na busca e seleção desta etapa do processo:

\begin{tabular}{|l|l|c|c|}
\hline $\begin{array}{c}\text { Cursos da área da saúde } \\
\text { oferecidos pela universidade de } \\
\text { São Paulo-USP }\end{array}$ & $\begin{array}{c}\text { Possuem } \\
\text { disciplina } \\
\text { empreende- } \\
\text { dorismo }\end{array}$ & $\begin{array}{c}\text { Cursos que possuem disciplinas de } \\
\text { gestão/administração }\end{array}$ & $\begin{array}{c}\text { Disciplina de } \\
\text { Gestão/Adm. que } \\
\text { possui } \\
\text { empreendedorismo }\end{array}$ \\
\hline $\begin{array}{c}\text { Ciências Biomédicas - Ênfase } \\
\text { em Biotecnologia }\end{array}$ & & $\begin{array}{l}\text { RCB0310 - Fundamentos de Gestão da } \\
\text { Biotecnologia }\end{array}$ & $\mathrm{x}$ \\
\hline $\begin{array}{c}\text { Ciências Biomédicas - Ênfase } \\
\text { em Ciências Básicas da Saúde }\end{array}$ & $\begin{array}{l}\text { REF0032 -Gestão e Marketing na Educação Física } \\
\text { e Esporte }\end{array}$ & $\mathrm{x}$ \\
\hline $\begin{array}{l}\text { Educação Física e Esporte - } \\
\text { Ciclo Básico }\end{array}$ & $\begin{array}{l}\text { REF0032-Gestão e Marketing na Educação Física } \\
\text { e Esporte }\end{array}$ & $\mathrm{x}$ \\
\hline $\begin{array}{c}\text { Educação Física e Esporte - } \\
\text { Ênfase em Educação Física e } \\
\text { Saúde }\end{array}$ & $\begin{array}{l}\text { REF0032- Gestão e Marketing na Educação Física } \\
\text { e Esporte }\end{array}$ & $\mathrm{x}$ \\
\hline $\begin{array}{l}\text { Educação Física e Esporte - } \\
\text { Ênfase em Esporte }\end{array}$ &
\end{tabular}




\begin{tabular}{|c|c|c|c|}
\hline \multirow{3}{*}{$\begin{array}{l}\text { Enfermagem - Bacharelado }(8 \\
\text { semestres) } \\
*\end{array}$} & & $\begin{array}{l}\text { ERG0410 - Organização e Gestão em Saúde e } \\
\text { Enfermagem na Atenção Hospitalar }\end{array}$ & \\
\hline & & $\begin{array}{l}\text { ERM0402 - Organização e Gestão em Saúde e } \\
\text { Enfermagem na Atenção Básica }\end{array}$ & \\
\hline & $\mathrm{x}$ & $\begin{array}{l}\text { ERG0021 - Empreendedorismo e Inovação em } \\
\text { Saúde * } \\
\text { (Disciplina Optativa) }\end{array}$ & \\
\hline \multirow{3}{*}{$\begin{array}{l}\text { Enfermagem - Bacharelado e } \\
\text { Licenciatura }\end{array}$} & & $\begin{array}{l}\text { ERG0341 - Organização e Gestão em Saúde e } \\
\text { Enfermagem na Atenção Hospitalar II }\end{array}$ & \\
\hline & & $\begin{array}{ll}\text { ERG0340 - Organização e Gestão em } \\
\text { Saúde e Enfermagem na Atenção Hospitalar I }\end{array}$ & \\
\hline & & $\begin{array}{l}\text { ERM0310 - Organização e Gestão em Saúde e } \\
\text { Enfermagem na Atenção Básica }\end{array}$ & \\
\hline \multicolumn{4}{|l|}{$\begin{array}{l}\text { Farmácia-bioquímica - } \\
\text { Modalidade Fármaco e } \\
\text { Medicamento - noturno }\end{array}$} \\
\hline \multirow[t]{2}{*}{ Farmácia-bioquímica - Integral } & & $\begin{array}{l}6022031 \text { - Administração e Marketing em } \\
\text { Empresas Farmacêuticas e Cosméticas }\end{array}$ & $\mathrm{x}$ \\
\hline & & $\begin{array}{l}6042037 \text { - Gestão em Assistência Farmacêutica e } \\
\text { Dispensação de Medicamentos no Serviço } \\
\text { Público }\end{array}$ & \\
\hline \multirow[t]{2}{*}{ Farmácia-bioquímica - Noturno } & & $\begin{array}{l}6022031 \text { - Administração e Marketing em } \\
\text { Empresas Farmacêuticas e Cosméticas }\end{array}$ & $x$ \\
\hline & & $\begin{array}{l}\text { 6042037 - Gestão em Assistência Farmacêutica e } \\
\text { Dispensação de Medicamentos no Serviço } \\
\text { Público }\end{array}$ & \\
\hline Fisioterapia & & $\begin{array}{ll}\text { RCG4005 } & \text { - Administração em } \\
\text { Fisioterapia } & \end{array}$ & \\
\hline \multicolumn{4}{|l|}{ Fonoaudiologia } \\
\hline \multirow[t]{2}{*}{ Medicina } & & $\begin{array}{l}\text { RCG0452 - Atenção à Saúde da Comunidade III - } \\
\text { Organização e Administração em Saúde }\end{array}$ & \\
\hline & & $\begin{array}{l}\text { RCG0489 Administração de } \\
\text { Organizações de Saúde }\end{array}$ & \\
\hline \multicolumn{4}{|l|}{ Odontologia } \\
\hline \multirow{2}{*}{ Psicologia - Bacharelado } & & 5940214- Gestão de Carreira I & \\
\hline & & 5940222Gestão de Carreira II & \\
\hline \multirow[t]{3}{*}{ Psicologia } & & 5961119Política e Gestão Educacional no Brasil & \\
\hline & & 5940214- Gestão de Carreira I & \\
\hline & & 5940222Gestão de Carreira II & \\
\hline Terapia Ocupacional & & $\begin{array}{l}\text { RCG4021 Planejamento e Gestão de } \\
\text { Serviços de Saúde }\end{array}$ & $x$ \\
\hline
\end{tabular}

Quadro 17: Detalhamento das informações das disciplinas identificadas

Fonte: elaborado pela autora

O quadro a seguir sintetiza os conteúdos voltados ao empreendedorismo, por meio de recortes dos objetivos, em que as palavras-chave utilizadas para a extração de dados puderam ser localizadas, apenas dos cursos com termo empreendedorismo em alguma disciplina: 


\begin{tabular}{|c|c|c|c|c|}
\hline $\begin{array}{l}\text { Cursos da } \\
\text { área da saúde }\end{array}$ & $\begin{array}{c}\text { Cursos que } \\
\text { possuem } \\
\text { disciplinas de } \\
\text { gestão com o } \\
\text { tema } \\
\text { empreendedori } \\
\text { smo }\end{array}$ & Objetivos & Programa Resumido & Programa \\
\hline $\begin{array}{l}\text { Ciências } \\
\text { Biomédicas - } \\
\text { Ênfase em } \\
\text { Ciências } \\
\text { Básicas da } \\
\text { Saúde }\end{array}$ & $\begin{array}{c}\text { RCB0310- } \\
\text { Fundamentos } \\
\text { de Gestão da } \\
\text { Biotecnologia } \\
\text { (apenas } 1 \\
\text { termo } \\
\text { localizado) }\end{array}$ & $\begin{array}{c}\text { Oferecer aos alunos } \\
\text { os conhecimentos } \\
\text { básicos de gestão e } \\
\text { das ferramentas } \\
\text { para o } \\
\text { desenvolvimento de } \\
\text { empresas e projetos } \\
\text { na indústria de base } \\
\text { biotecnológica. } \\
\text { Destacar a } \\
\text { importância da } \\
\text { geração de } \\
\text { propriedade } \\
\text { intelectual para o } \\
\text { desenvolvimento } \\
\text { nacional. Discutir o } \\
\text { setor biotecnológico } \\
\text { nacional bem como } \\
\text { contextualiza-lo no } \\
\text { cenário } \\
\text { internacional. } \\
\text { Estimular o } \\
\text { empreendedorismo. }\end{array}$ & $\begin{array}{c}\text { Apresentação de } \\
\text { ferramentas gerenciais } \\
\text { básicas, como gestão de } \\
\text { recursos humanos, fluxo } \\
\text { de caixa, planejamento de } \\
\text { custo, estratégias } \\
\text { negociais e } \\
\text { desenvolvimento de } \\
\text { negócios. Discussão das } \\
\text { etapas básicas de gestão } \\
\text { de projetos. Discussão da } \\
\text { do processo de geração e } \\
\text { proteção da propriedade } \\
\text { intelectual e dos aspectos } \\
\text { regulatórios para } \\
\text { introdução de produtos no } \\
\text { mercado. }\end{array}$ & $\begin{array}{c}\text { • Introdução à Gestão de } \\
\text { Negócios } \\
\text { • Gestão de Projetos } \\
\text { Biotecnológicos: As } 5 \text { etapas da } \\
\text { gestão (Iniciação, Planejamento, } \\
\text { Execução, Controle e } \\
\text { Fechamento) } \\
\text { • Gestão da Inovação, } \\
\text { Propriedade Intelectual e } \\
\text { Patentes e Transferência de } \\
\text { Tecnologia. } \\
\text { - Regulação de Produtos } \\
\text { Biotecnológicos }\end{array}$ \\
\hline $\begin{array}{l}\text { Educação } \\
\text { Física e } \\
\text { Esporte - } \\
\text { Ênfase em } \\
\text { Educação } \\
\text { Física e Saúde }\end{array}$ & $\begin{array}{c}\text { REF0032 } \\
\text { Gestã } \\
\text { o e Marketing } \\
\text { na Educação } \\
\text { Física e Esporte } \\
\text { (apenas } 1 \\
\text { termo } \\
\text { localizado) }\end{array}$ & $\begin{array}{l}\text { Geral do Curso } \\
\text { Preparar } \\
\text { profissionais para } \\
\text { compreender a } \\
\text { Educação Física e o } \\
\text { Esporte, } \\
\text { capacitando-os para } \\
\text { atuar nos diferentes } \\
\text { segmentos das } \\
\text { organizações sociais. } \\
\text { Geral da Disciplina } \\
\text { Apresentar conceitos } \\
\text { e aplicações práticas } \\
\text { da gestão e do } \\
\text { marketing para } \\
\text { serviços na área do } \\
\text { esporte e do } \\
\text { exercício físico } \\
\\
\text { Específicos da } \\
\text { Disciplina } \\
\text { Ao final do semestre } \\
\text { o aluno deverá ser } \\
\text { capaz de: } \\
\text { 1- Descrever a } \\
\text { gestão esportiva } \\
\text { com base na } \\
\text { coordenação entre a } \\
\text { produção e o } \\
\text { marketing de } \\
\text { serviços esportivos. }\end{array}$ & $\begin{array}{l}\text { Diferenças entre gestão e } \\
\text { marketing. Gestão } \\
\text { esportiva. Funções do } \\
\text { gestor. Indústria do } \\
\text { esporte. Organizações } \\
\text { esportivas. Gestão de } \\
\text { recursos humanos em } \\
\text { organizações esportivas. } \\
\text { Marketing esportivo. } \\
\text { Comportamentos do } \\
\text { consumidor do esporte. } \\
\text { Eventos esportivos. } \\
\text { Marketing pessoal. Leis } \\
\text { federais e estaduais de } \\
\text { incentivo ao esporte. }\end{array}$ & $\begin{array}{c}\begin{array}{c}\text { Definição da área de gestão } \\
\text { esportiva }\end{array} \\
\text { Indústria do esporte } \\
\text { Gestão esportiva no terceiro } \\
\text { setor } \\
\text { Gestão esportiva no primeiro } \\
\text { setor } \\
\text { Funções do gestor e } \\
\text { classificação dos serviços } \\
\text { esportivos } \\
\text { Gestão de RH em entidades } \\
\text { esportivas I } \\
\text { Gestão de RH em entidades } \\
\text { esportivas II } \\
\text { Tópicos especiais em gestão de } \\
\text { RH: Liderança } \\
\text { Tópicos especiais em gestão de } \\
\text { RH: Motivação } \\
\text { Tópicos especiais em gestão de } \\
\text { RH: Justiça e comprometimento } \\
\text { Finanças do esporte I } \\
\text { Case } 1 \text { - Gestão de Recursos } \\
\text { Humanos } \\
\text { Organização de eventos } \\
\text { esportivos } \\
\text { Organização de torneios } \\
\text { esportivos } \\
\text { Organização de megaeventos } \\
\text { esportivos } \\
\text { Oportunidades e ameaças na } \\
\text { organização de megaeventos }\end{array}$ \\
\hline
\end{tabular}




\begin{tabular}{|c|c|c|c|c|}
\hline & & $\begin{array}{l}\text { 2- Definir as quatro } \\
\text { funções } \\
\text { administrativas } \\
\text { básicas, isto é: } \\
\text { planejar, organizar, } \\
\text { liderar e avaliar. } \\
\text { 3- Identificar } \\
\text { aplicações práticas } \\
\text { destas funções } \\
\text { dentro de } \\
\text { organizações } \\
\text { esportivas. } \\
\text { 4- Identificar as cinco } \\
\text { grandes áreas da } \\
\text { administração } \\
\text { (produção, finanças, } \\
\text { administraçãa de } \\
\text { recursos humanos, } \\
\text { administração de } \\
\text { recursos materiais, e } \\
\text { marketing) } \\
\text { considerando o } \\
\text { produto esporte e } \\
\text { exercício físico. }\end{array}$ & & $\begin{array}{l}\text { Comportamentos do } \\
\text { consumidor do esporte I } \\
\text { Comportamentos do } \\
\text { consumidor do esporte II } \\
\text { Marketing e marketing de } \\
\text { serviços } \\
\text { Estratégias de marketing no } \\
\text { setor esportivo } \\
\text { Case 2 - Marketing esportivo } \\
\text { Marketing pessoal para } \\
\text { profissionais de EFE } \\
\text { Empreendedorismo }\end{array}$ \\
\hline $\begin{array}{l}\text { Farmácia- } \\
\text { bioquímica - } \\
\text { Noturno (12 } \\
\text { semestres) }\end{array}$ & $\begin{array}{c}6022031 \text { - } \\
\text { Administração e } \\
\text { Marketing em } \\
\text { Empresas } \\
\text { Farmacêuticas e } \\
\text { Cosméticas } \\
\text { (apenas } 1 \\
\text { termo } \\
\text { localizado) }\end{array}$ & $\begin{array}{l}\text { Familiarizar os } \\
\text { discentes com os } \\
\text { conceitos } \\
\text { fundamentais de } \\
\text { administração geral } \\
\text { e marketing } \\
\text { farmacêutico, de } \\
\text { modo a lhes oferecer } \\
\text { os elementos } \\
\text { necessários para a } \\
\text { atuação prática na } \\
\text { gestão de } \\
\text { organizações } \\
\text { farmacêuticas e } \\
\text { cosméticas. } \\
\text { - Propiciar aos } \\
\text { discentes uma visão } \\
\text { crítica e prática das } \\
\text { atividades } \\
\text { administrativas e de } \\
\text { marketing no } \\
\text { ambiente das } \\
\text { empresas do setor } \\
\text { farmacêutico e } \\
\text { cosmético. } \\
\text { - Discutir as novas } \\
\text { formas de } \\
\text { participação do } \\
\text { profissional } \\
\text { farmacêutico no } \\
\text { mercado de } \\
\text { trabalho. }\end{array}$ & $\begin{array}{c}\text { O conteúdo programático } \\
\text { da Disciplina compreende } \\
\text { da fundamentação teórica } \\
\text { da administração geral e } \\
\text { de marketing } \\
\text { farmacêutico. Fornece } \\
\text { uma análise do ambiente } \\
\text { econômico e dos } \\
\text { mercados farmacêuticos e } \\
\text { cosméticos e o } \\
\text { entendimento da sua } \\
\text { influência nas atividades } \\
\text { administrativas de } \\
\text { planejamento, } \\
\text { organização, liderança e } \\
\text { controle. Proporciona uma } \\
\text { visão crítica das atividades } \\
\text { administrativas } \\
\text { enfatizando essas } \\
\text { atividades na função do } \\
\text { marketing. Discuti as } \\
\text { novas tendências } \\
\text { administrativas aplicadas } \\
\text { nas organizações } \\
\text { farmacêuticas e } \\
\text { cosméticas. }\end{array}$ & $\begin{array}{l}\text { 1) Fundamentos da } \\
\text { administração } \\
\text { 1.1) Gestão e ética } \\
\text { 1.2) Tomada de decisão } \\
\text { administrativa } \\
\text { 2) Áreas da administração } \\
\text { aplicadas nas empresas } \\
\text { farmacêuticas e cosméticas } \\
\text { 2.1) Recursos Humanos } \\
\text { 2.2) Finanças } \\
\text { 2.3) Produção } \\
\text { 2.4) Marketing } \\
\text { 3)Função administrativa } \\
\text { Planejamento analisada no } \\
\text { contexto das empresas } \\
\text { farmacêuticas e cosméticas } \\
\text { 3.1) Planejamento de Marketing } \\
\text { 3.1.1) Análise do mercado } \\
\text { farmacêutico e cosmético } \\
\text { 3.1.2) Análise do } \\
\text { comportamento do consumidor: } \\
\text { aplicação em empresas } \\
\text { farmacêuticas e cosméticas } \\
\text { 3.2) Planejamento das } \\
\text { estratégias de ciclo de vida de } \\
\text { produtos com aplicação dos 4P's } \\
\text { do marketing } \\
\text { 4) Função administrativa } \\
\text { Organização analisada no } \\
\text { contexto das empresas } \\
\text { farmacêuticas e cosméticas } \\
\text { 5) Função administrativa } \\
\text { Liderança analisada no contexto } \\
\text { das empresas farmacêuticas e } \\
\text { cosméticas } \\
\text { 5.1) Motivação nas organizações } \\
\text { 5.2) Trabalho em equipe } \\
\text { 6) Função administrativa }\end{array}$ \\
\hline
\end{tabular}




\begin{tabular}{|c|c|c|c|c|}
\hline & & & & $\begin{array}{l}\text { Controle analisada no contexto } \\
\text { das empresas farmacêuticas e } \\
\text { cosméticas } \\
\text { 6.1) Controle da qualidade total } \\
\text { 7) Tendências em administração } \\
\text { e a sua aplicação no contexto } \\
\text { farmacêutico e cosmético: } \\
\text { Gestão de Inovação e } \\
\text { Empreendedorismo. }\end{array}$ \\
\hline $\begin{array}{l}\text { Terapia } \\
\text { Ocupacional }\end{array}$ & $\begin{array}{l}\text { RCG4021 } \\
\text { Planej } \\
\text { amento e } \\
\text { Gestão de } \\
\text { Serviços de } \\
\text { Saúde }\end{array}$ & $\begin{array}{l}\text { Trazer conceitos } \\
\text { práticos e atuais } \\
\text { sobre planejamento } \\
\text { e a gestão de } \\
\text { diferentes serviços } \\
\text { de Saúde no qual o } \\
\text { Terapeuta } \\
\text { Ocupacional esteja } \\
\text { inserido nas } \\
\text { instâncias públicas e } \\
\text { privadas. }\end{array}$ & $\begin{array}{c}\text { Princípios gerais de } \\
\text { Marketing/Empreendedor } \\
\text { ismo } \\
\text { Conceitos de } \\
\text { planejamento e } \\
\text { Gerenciamento de } \\
\text { serviços de saúde } \\
\text { Noções de gestão de } \\
\text { pessoas, gestão de } \\
\text { equipes } \\
\text { Workshop sobre } \\
\text { planejamento de serviços } \\
\text { e gestão }\end{array}$ & $\begin{array}{c}\text { Níveis de Planejamento e } \\
\text { gerenciamento em saúde/SUS e } \\
\text { Planejamento } \\
\text { Gestão de serviços } \\
\text { públicos/Gestão nos diferentes } \\
\text { níveis de complexidade de } \\
\text { atenção em saúde } \\
\text { Indicadores de Saúde e Sistemas } \\
\text { de Informação em Saúde } \\
\text { Rede Interagencial de } \\
\text { Informação para a Saúde - RIPSA } \\
\text { Planejamento/gerenciamento } \\
\text { em saúde e a prática do } \\
\text { Terapeuta Ocupacional } \\
\text { Marketing/Administração e } \\
\text { Comunicação para serviços de } \\
\text { saúde } \\
\text { Marketing de } \\
\text { serviços/Marketing de } \\
\text { Relacionamento/Marketing na } \\
\text { prática privada } \\
\text { Gestão de Pessoas em } \\
\text { ambientes de saúde/gestão de } \\
\text { equipes } \\
\text { Processo de saúde em equipes } \\
\text { multiprofissionais } \\
\text { Empreendedorismo nos } \\
\text { serviços de saúde } \\
\text { Avaliação da qualidade dos } \\
\text { serviços em saúde }\end{array}$ \\
\hline
\end{tabular}

Quadro 18: Detalhamento das matrizes que contem tema empreendedorismo Fonte: Autora

\section{O quadro a seguir sintetiza os resultados da pesquisa documental:}

\begin{tabular}{|c|c|c|c|}
\hline $\begin{array}{c}\text { Cursos da área da saúde oferecidos pela } \\
\text { universidade de São Paulo-USP - Campus Ribeirão } \\
\text { Preto/SP. }\end{array}$ & 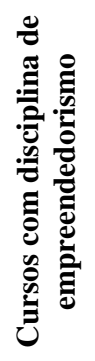 & 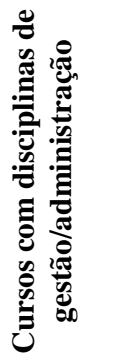 & 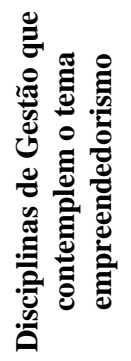 \\
\hline \multicolumn{4}{|l|}{ Ciências Biomédicas - Ênfase em Biotecnologia em Saúde } \\
\hline Ciências Biomédicas - Ênfase em Ciências Básicas da Saúde & & $\mathrm{x}$ & $\mathrm{x}$ \\
\hline Educação Física e Esporte - Ciclo Básico & & $\mathrm{x}$ & $x$ \\
\hline Educação Física e Esporte - Ênfase em Educação Física e Saúde & & $\mathrm{x}$ & $x$ \\
\hline
\end{tabular}




\begin{tabular}{|l|c|c|c|}
\hline Educação Física e Esporte - Ênfase em Esporte & & $\mathrm{x}$ & $\mathrm{x}$ \\
\hline Enfermagem - Bacharelado e Licenciatura & $\mathrm{x}$ & $\mathrm{x}$ & \\
\hline Farmácia-bioquímica - Integral e noturno & & $\mathrm{x}$ & $\mathrm{x}$ \\
\hline Fisioterapia & & $\mathrm{x}$ & \\
\hline Fonoaudiologia & & $\mathrm{x}$ & \\
\hline Medicina & & & \\
\hline Odontologia & & $\mathrm{x}$ & \\
\hline Psicologia - Bacharelado & $\mathrm{x}$ & $\mathrm{x}$ \\
\hline Terapia Ocupacional & & & \\
\hline
\end{tabular}

Quadro 19: Síntese dos conteúdos

Fonte: Autora

Partindo da demanda por essas competências elencadas tanto na normatização das diretrizes dos cursos da área da saúde como também nas produções científicas, espera-se que os profissionais da área estejam mais preparados para se inserirem no mundo do trabalho. Para que tais competências sejam desenvolvidas num ambiente propício, cabe à universidade mais esse papel, o da disseminação da prática do empreendedorismo, como já é visto em alguns países, como por exemplo, na América do Norte, segundo Souza et.al (2004), praticamente todas as instituições de ensino superior trazem em seus currículos, disciplinas sobre empreendedorismo. Isso, talvez possa ser explicado pela necessidade já detectada, de se enfrentar o risco, a incerteza, e ter a inovação como temas nucleares do desenvolvimento das organizações.

\subsection{Considerações acerca do ensino do empreendedorismo na saúde}

Observou-se que o termo empreendedorismo ainda é interpretado por muitos como ter ou abrir um novo negócio. Esse equívoco leva muitos educadores a resistirem a inclusão de conteúdos sobreo empreendedorismo nos currículos acadêmicos. (LUCENA e CENTURIÓN, 2011). No Entanto, a palavra empreendedorismo vai bem além dessa ideia, a atitude empreendedora envolve o desenvolvimento de potencialidades fundamentais em um âmbito maior que o saber técnico científico, buscando na autorrealização, a valorização do ser e da coletividade.

A prática de educação empreendedora, como o próprio nome diz, não deve ser adotada apenas no campo conceitual, teórico, conteudista em sala de aula, mas sim, com ações que envolvam os alunos para sua concretização e emancipação (DORNELAS, 2014). Por 
serem características comportamentais, essas precisam ser desenvolvidas de dentro para fora, ou seja, contextualizar o ensino para a busca de soluções que partem do aluno, como um agente autônomo nesse processo e tendo o educador como um mentor, um mestre, que direciona e apoia, dando espaço "monitorado" para fomentar o protagonismo do sujeito aluno, como define a pedagogia freiriana (LUCENA e CENTURIÓN, 2011).

Os princípios freireanos - ler o mundo; compartilhar a leitura do mundo; educação como ato de produção e de reconstrução do saber; educação como prática da liberdade revelam que há uma estreita relação entre estes princípios e a educação empreendedora (LUCENA e CENTURIÓN, 2011). O princípio central da proposta freireana de educação transformadora sob a concepção problematizadora está diretamente relacionado com a filosofia do empreendedorismo, sobretudo no campo da enfermagem, no sentido de formar profissionais críticos-reflexivos, socialmente responsáveis e preocupados com as demandas da sociedade em que atuam, atributos indispensáveis para essa profissão.

\subsection{Fundamentação Teórica para o uso do Instrumento: o Perfil Empreendedor desenvolvido por David McClelland}

Inúmeros trabalhos apontam David McClelland como sendo um dos principais estudiosos das características do comportamento empreendedor (FILION, 1999; KRÜGER, et.al. 2017; CAGGY, et.al. 2017; TORRES; 2018; MARION-SANTOS e PAIXÃO, 2013; SANTOS et.al 2014; FONSECA e MUYLDER, 2010; BARLACK, 2014). Grande parte de suas obras foram dedicadas ao que chamou de características empreendedoras pessoais (Personal Entrepreneurial Characteristics - PEC's) inerentes ao empreendedor de sucesso. McClelland (1961) conceituou e testou a questão comportamentalista, objetivando identificar fatores psicológicos e culturais que levava certas pessoas a ter motivação para realizar algo.

Em seus estudos, iniciados na década de 1950, McClelland, formado em psicologia, debruçou-se em estudar a história da civilização com base nas disputas entre americanos e soviéticos, buscando compreender explicações para essa disputa. Suas pesquisas trouxeram histórias de heróis que superavam dificuldades e a partir daí, buscou entender características de superação que os diferenciavam. Para ele, pessoas sob pressão, desenvolvem necessidades de superação, tendo de agir sob certas situações, estabelecendo uma 
correspondência com a necessidade de agir do empreendedor (FONSECA e MUYLDER, 2010). McClelland (1961), vincula o empreendedor a aspectos relativos às características criativas e intuitivas. São estas as duas principais correntes que demarcam seu campo de pesquisa.

Para McClelland (1961), não havia relação consistente entre genética e
empreendedorismo, mas, sim, entre meio ambiente e empreendedorismo. A
necessidade de realização do empreendedor seria desenvolvida a partir da cultura,
das experiências e da aprendizagem. Os traços que caracterizariam os
empreendedores não seriam "constitucionais", mas sim "moldados pelo ambiente
em que vive" (McClelland, 1961, p. 273).

Suas publicações dominaram os estudos sobre o comportamento empreendedor em meados da década de 1970 até 1980, apesar de ter se iniciado muitos anos antes. Para ele, o indivíduo empreendedor manifesta uma série de características que o identifica, distinguindo-o de acordo com o conjunto de habilidades que mais se aproxima da sua forma de ser, denominadas de características comportamentais empreendedoras e podem contribuir para o sucesso dos empreendimentos, razão pela qual tais características ganham relevância, podendo, segundo ele, serem desenvolvidas (KRÜGER, 2017).

Em seus estudos, criou o teste psicológico denominado ‘Conheça suas características comportamentais', objetivando a avaliação de competências. Esse teste, que foi conhecido e aplicado posteriormente em 34 países, seria uma alternativa à aplicação de testes de inteligência que não mensuram a capacidade empreendedora, apenas o sucesso do desempenho (MINELLO, 2017).

Para McClelland, as características empreendedoras contribuem para que o empreendedor seja um ator social dinâmico quanto ao seu comportamento. A partir disso, para identificar o comportamento empreendedor e as respectivas características empreendedoras é imprescindível analisar seus trabalhos, pois parte da ideia de que empreender é o lócus central das ideologias de diferentes sociedades ao redor do mundo (TORRES, 2018). O autor acreditava que a questão do comportamento poderia ser mensurada pela observação da questão comportamental. Propôs a identificação de fatores psicológicos, culturais e comportamentais que direcionam certas pessoas a ter motivação para realizar algo.

Por meio de suas pesquisas, McClelland, em 1958, desenvolveu um treinamento de natureza comportamental denominado Anchievement Motive Trainning (AMT), ou, 
Treinamento de Motivação para a Realização (FONSECA e MUYLDER, 2010). Ao estudar nove edições do TMR, organizadas em cinco países, observou que o treinamento resultou em significativas melhorias no alcance de metas, chamando a atenção da agência dos Estados Unidos para o Desenvolvimento Internacional - USAID. O projeto passou a contar com instituições parceiras, dentre elas, a McBer\&Co, que tinha McClelland como sócio. O projeto criado por estas parcerias teria durado cinco anos e envolvido 34 países, de culturas e realidades econômicas diferentes, para atender as críticas recebidas pelos pesquisadores da época (MORALES, 2004, apud TORRES, 2018). As empresas McBer e MSI, especialistas na área, foram responsáveis por realizar os primeiros testes, sendo a McBer, responsável pelas duas atividades iniciais e a MSI responsável pela última tarefa, dividida em três segmentos:

a) identificar características pessoais associadas ao empreendedorismo bemsucedido no contexto de diversos países em desenvolvimento.

b) desenvolver instrumentos capazes de prever quais empreendedores teriam mais chances de serem bem-sucedidos nos negócios.

c) identificar e avaliar programas voltados para a melhoria do desempenho na condução de negócios de empreendedores e potenciais empreendedores.

McClelland desenvolveu suas pesquisas ao longo de quase cinco décadas, estudando os aspectos comportamentais dos empreendedores, sobretudo relacionados à motivação para realizar seus feitos. Percebeu-os como indivíduos diferenciados e passou a estudar suas principais características exteriorizadas, a fim de desenvolver programas que pudessem estimular o desenvolvimento dessas características. Partia da premissa que o sucesso dos indivíduos empreendedores estava diretamente ligado ao desenvolvimento da nação e a eles deveria ser dado todo o apoio (MARION-SANTOS e PAIXÃO, 2013).

A partir deste estudo foi criado em 1982, um treinamento piloto chamado de Entrepreneur Trainning Workshop (ETW) aplicados entre 1985 e 1986 para cerca de 20 países e 500 participantes inicialmente. Para avaliar a eficácia da teoria de McClelland, de que era possível aumentar o desempenho dos empreendedores por meio de treinamento comportamental, realizou-se uma comparação com o grupo que não havia passado pelo treinamento (grupo controle). Segundo Fonseca e Muylder (2010) o relatório deste processo 
apontou melhorias substanciais no grupo de tratamento em relação às respostas observadas no grupo controle, apontando como favorável a aplicação das atividades do programa.

O autor partiu da tese de que a motivação humana responde, pelo menos em parte, pelo crescimento econômico de uma nação. Sua teoria sobre a motivação humana compreende três necessidades dominantes: de realização, de afiliação, e de poder, resumidas a seguir (MCCLELLAND, 1987, p. 201).

- Necessidade de realização: o indivíduo necessita pôr à prova seus limites, fazer um bom trabalho e mensurar as realizações pessoais. Pessoas com alta necessidade de realização são aquelas que procuram mudanças em suas vidas, estabelecem metas realistas e realizáveis e colocam-se em situações competitivas. Seus estudos comprovaram que a carência de realização é a primeira identificada entre os empreendedores bem-sucedidos. A necessidade de realização, nesse contexto, impulsiona as pessoas a iniciar e a construir um empreendimento.

- Necessidade de afiliação: ocorre quando há alguma evidência quanto à preocupação em estabelecer, manter ou restabelecer relações emocionais positivas com outras pessoas.

- Necessidade de poder: caracterizada principalmente pela forte preocupação em exercer autoridade sobre os outros, de executar ações poderosas.

Estes estudos iniciais, sob a tríade realização-afiliação-poder, resultaram em vinte características comportamentais empreendedoras. Os estudos foram modificados durante o final de 1985 e início de 1986, e as características foram reduzidas para dez características comportamentais empreendedoras. A redução das características ocorreu por meio de estudos buscando uma nova formatação da nomenclatura e subdivisão de grupos, com novos módulos e exercícios, incorporando-os em programas existentes no Quênia, Senegal, Inglaterra e Estados Unidos. Mais adiante novas revisões foram realizadas a partir desta experiência, e o pacote final completo foi apresentado com as dez características comportamentais empreendedora e montado para uma aplicação teste no Malawi, em julho de 1986 (FERNANDES, 2014). As características comportamentais empreendedoras, sendo 
estas, as características que o empreendedor bem-sucedido deve ter ou que precisa desenvolver:

1. - busca de oportunidades e iniciativa;

2. - persistência;

3. - comprometimento;

4. - exigência de qualidade e eficiência;

5. - correr riscos calculados;

6. - estabelecimento de metas;

7. - busca de informações;

8. - planejamento e monitoramento sistemáticos;

9. - persuasão e rede de contatos e;

10. - independência e autoconfiança.

Tais características devem estar presentes no empreendedor. Os comportamentos respectivos a cada característica (MCCLELLAND, 1987), descritos a seguir:

Busca de oportunidade e iniciativa: o indivíduo vê e age sobre novas ou incomuns oportunidades de negócios. Age antes de ser solicitado ou forçado pelas circunstâncias.

Correr riscos calculados: avalia e calcula riscos deliberadamente. Toma medidas para reduzir os riscos ou controlar os resultados. Coloca-se em situações que implicam desafios ou riscos moderados.

Exigência de qualidade e eficiência: encontra maneiras de fazer as coisas melhor, mais rápido ou mais barato. Age de maneira a fazer coisas que satisfazem ou excedem padrões de excelência.

Persistência: age repetidamente para atender um desafio ou superar um obstáculo. Muda para uma estratégia alternativa para alcançar um objetivo.

Comprometimento: faz um sacrifício pessoal ou despende esforço extraordinário para completar um trabalho. Assume responsabilidade pessoal pelo desempenho necessário ao atingimento de metas e objetivos colabora com os empregados ou se coloca no lugar deles, se necessário, para terminar um trabalho. 
Busca de informações: o indivíduo dedica-se pessoalmente a obter informações de clientes, fornecedores e concorrentes. Utiliza contatos pessoais e de negócios para obter informações úteis.

Estabelecimento de metas: define metas de longo prazo, claras e específicas. Continuamente define e revisa os objetivos de curto prazo.

Planejamento e monitoramento sistemáticos: planeja dividindo tarefas de grande porte em sub-tarefas; constantemente revisa seus planos, levando em conta os resultados obtidos e mudanças circunstanciais; mantém registros financeiros e utiliza-os para tomar decisões.

Persuasão e redes de contato: utiliza estratégias deliberadas para influenciar ou persuadir os outros. Utiliza pessoas chave como agentes para atingir seus próprios objetivos.

Independência e autoconfiança: busca autonomia em relação a normas e controles de outros. Mantém seu ponto de vista mesmo diante da oposição ou de resultados inicialmente desanimadores. Expressa confiança na sua própria capacidade de completar uma tarefa difícil ou de enfrentar um desafio (KRUGER, 2016).

Para mensurar tais características foi desenvolvido um questionário baseado nas dez CCE's de McClelland e composto por 55 afirmações, conforme apresentado no quadro a seguir. O treinamento oriundo deste projeto é mundialmente conhecido como EMPRETEC ${ }^{19}$. Desde seu início em 1988, o programa já havia capacitado mais de 340 mil profissionais em 36 países até 2016, dentre eles, o Brasil, considerado o país que mais aplica o programa, por meio do SEBRAE, única instituição brasileira autorizada pelo programa e que já formou mais de 250 mil pessoas (TORRES, 2018).

${ }^{19}$ De acordo com o GEM - Global Entrepreuner Management, o programa EMPRETEC é o grande fomentador no processo de geração de capacidade empreendedora e tem como objetivo promover o empreendedorismo e aumentar a capacidade produtiva e competitiva internacional de empresas de pequeno e médio porte nos países em desenvolvimento. 0 programa tem duração de 06 (seis) dias, ou 60 horas, os participantes são movidos a reconhecer e a praticar, em si e no coletivo, as características empreendedoras de David McClelland. (SEBRAE, 2017; FONSECA e MUYLDER, 2010). 


\section{Quadro - Questionário das CCE's de David McClelland}

1. Esforço-me para realizar as coisas que devem ser feitas.

2. Quando me deparo com um problema difícil, levo muito tempo para encontrar a solução.

3. Termino meu trabalho / atividade a tempo.

4. Aborreço-me quando as coisas não são feitas devidamente.

5. Prefiro situações em que posso controlar ao máximo o resultado final.

6. Gosto de pensar no futuro.

7. Quando começo uma tarefa ou projeto novo, coleto todas as informações possíveis antes de dar prosseguimento a ele.

8. Planejo um projeto grande dividindo-o em tarefas mais simples.

9. Consigo que os outros me apoiem em minhas recomendações.

10. Tenho confiança que posso estar bem-sucedido em qualquer atividade que me proponha executar.

11. Não importa com quem fale, sempre escuto atentamente.

12. Faço as coisas que devem ser feitas sem que os outros tenham que me pedir.

13. Insisto várias vezes para conseguir que as outras pessoas façam o que desejo.

14. Sou fiel às promessas que faço.

15. Meu rendimento no trabalho / atividades é melhor do que o das outras pessoas com quem trabalho.

16. Envolvo-me com algo novo só depois de ter feito o possível para assegurar seu êxito.

17. Acho uma perda de tempo me preocupar com o que farei daminha vida.

18. Procuro conselhos das pessoas que são especialistas no ramo em que estou atuando.

19. Considero cuidadosamente as vantagens e desvantagens de diferentes alternativas antes de realizar uma tarefa.

20. Não perco muito tempo pensando em como posso influenciar as outras pessoas.

21. Mudo a maneira de pensar se os outros discordam energicamente dos meus pontos de vista.

22. Aborreço-me quando não consigo o que quero.

23. Gosto de desafios e novas oportunidades.

24. Quando algo se interpõe entre o que eu estou tentando fazer, persisto em minha tarefa.

25. Se necessário não me importo de fazer o trabalho dos outros para cumprir um prazo de entrega.

26. Aborreço-me quando perco tempo.

27. Considero minhas possibilidades de êxito ou fracasso antes de começar atuar.

28. Quanto mais especificas forem minhas expectativas em relação ao que quero obter na vida, maiores serão minhas possibilidades de êxito.

29. Tomo decisões sem perder tempo buscando informações.

30. Trato de levar em conta todos os problemas que podem se apresentar e antecipo o que eu faria caso sucedam.

31. Conto com pessoas influentes para alcançar minhas metas.

32. Quando estou executando algo difícil e desafiador, tenho confiança em seu sucesso.

33. Tive fracassos no passado.

34. Prefixo executar tarefas que domino perfeitamente e em que me sinto seguro

35. Quando me deparo com sérias dificuldades, rapidamente passo para outras atividades.

36. Quando estou fazendo um trabalho para outra pessoa, me esforço de forma especial para que fique satisfeita com o trabalho.

37. Nunca fico realmente satisfeito com a forma como são deitas as coisas; sempre considero que há uma maneira melhor de fazê-las.

38. Executo tarefas arriscadas. 
39. Conto com um plano claro de vida.

40. Quando executo um projeto para alguém, faço muitas perguntas para assegurar-me de que entendi o que quer.

41. Enfrento os problemas na medida em que surgem, em vez de perder tempo, antecipandoos.

42. Para alcançar minhas metas, procuro soluções que beneficiem todas as pessoas envolvidas em um problema.

43. O trabalho que realizo é excelente.

44. Em algumas ocasiões obtive vantagens de outras pessoas.

45. Aventuro-me a fazer coisas novas e diferentes das que fiz no passado.

46. Tenho diferentes maneiras de superar obstáculos que se apresentam para a obtenção de minhas metas.

47. Minha família e vida pessoal são mais importantes para mim do que as datas de entregas de trabalho determinadas por mim mesmo.

48. Encontro a maneira mais rápida de terminar os trabalhos, tanto em casa quanto no trabalho / faculdade.

49. Faço coisas que as outras pessoas consideram arriscadas.

50. Preocupo-me tanto em alcançar minhas metas semanais quanto minhas metas anuais.

51. Conto com várias fontes de informação ao procurar ajuda para a execução de tarefas e projetos.

52. Se determinado método para enfrentar um problema não der certo, recorro a outro.

53. Posso conseguir que pessoas com firmes conviç̧ões e opiniões mudem seu modo de pensar.

54. Mantenho-me firme em minhas decisões, mesmo quando as outras pessoas se opõem energicamente.

55. Quando desconheço algo, não hesito em admiti-lo.

Quadro 20: Questionário das CCE's de David McClelland

Fonte: Krüger (2016), Marion-Santos e Paixão (2014), Fernandes (2014), Torres (2018).

A aplicação do referido instrumento segue os seguintes passos (KRUGER, 2016):

- Utiliza-se uma escala Likert de 5 pontos para responder esse questionário;

- Dimensões: As 55 questões compõem as dez dimensões das características comportamentais empreendedoras e são divididas em 11 grupos de cinco questões. O último grupo refere-se ao grupo denominado fator de correção;

- Cálculo: Para descobrir o valor de cada dimensão, somam-se as respectivas assertivas do grupo e diminuem-se as questões negativas, nestas acrescenta-se 6 (seis) pontos ao final do somatório;

- Fator de correção: As questões de número 11, 22, 33, 44 e 55 correspondem ao "Fator de Correção", utilizado para evitar que, muitas vezes de modo inconsciente, o respondente apresente uma autoimagem excessivamente favorável. O Fator de Correção é utilizado se o somatório da pontuação dessas questões for igual ou 
superior a 20 (vinte) pontos. Se isso ocorrer, todas as CCE's devem ser corrigidas com a subtração dos pontos correspondentes;

- A pontuação máxima é de 25 (vinte e cinco) pontos para cada uma das dimensões. Quando o total for inferior a 15 pontos, o indivíduo não possui a respectiva característica, ou seja, inexistente. Se a pontuação for entre 15,00 e 17,50 o indivíduo possui um perfil empreendedor de nível baixo, se a pontuação for entre 17,51 e 20, 00, o indivíduo possui perfil empreendedor satisfatório e acima de 20, 00 possui perfil empreendedor de nível alto. A análise resulta em captar os resultados de todas as características, sendo considerado empreendedor quando possuir as dez características, indicadas na proposta das CCE's (MCCLELLAND, 1987).

Neste estudo, em que foram listadas as características do comportamento empreendedor, David McClelland destacou o comportamento das pessoas com seu vínculo de trabalho, organizações e mercado de trabalho, evidenciando os temas relacionados ao empreendedorismo, empreendedor e comportamento empreendedor, o que evidencia a importância de estudar e fomentar o empreendedor diante de sua importância no desenvolvimento econômico. Assim, quanto mais empreendedores uma sociedade tiver, e maior for o valor dado a eles, maior será a quantidade de jovens que tenderão a imitá-los, incutindo na cultura da sociedade o espírito e as características peculiares do empreendedor.

Acredita-se que a maior contribuição da obra de McClelland é a constatação da capacidade empreendedora de jovens, que pode ser desenvolvida no cotidiano educacional (SILVA, 2015). Conforme McClelland observou em seus estudos, os indivíduos com maior necessidade de realização são mais propensos a empreender, e o desenvolvimento das competências críticas necessárias para o sucesso empresarial pode dar-se espontaneamente, fato observado em indivíduos que obtiveram o sucesso sem ter participado de nenhum programa formal de capacitação (KRÜGER, 2017).

No entanto, o autor reforça que essas competências podem ser estimuladas e desenvolvidas com programas específicos, obtendo-se, com os indivíduos, o mesmo sucesso daqueles que o alcançaram de forma inata. Dessa forma, dedicou-se ao entendimento dessas competências, batizadas de características do comportamento empreendedor (KRÜGER, 2016; LOPES, 2010) e na importância de se inserir tais características no universo acadêmico no sentido de formar profissionais com tais habilidades desenvolvidas. 
Na análise da obra de McClelland, Fillion (1999) apresenta um estudo do sistema de valoração como referência básica para explicar o comportamento empreendedor, partindo do escopo que na história da humanidade as sociedades procuraram seguir os modelos de seus heróis. A capacidade empreendedora poderia, portanto, ser tomada como um modelo de sucesso a ser seguido e instrumentalizado dentro do universo acadêmico.

\begin{abstract}
As características comportamentais empreendedoras podem ajudar os indivíduos a enfrentar os desafios de empreender, assim como a inexistência delas, pode inviabilizar a formação de um empreendimento. O comportamento empreendedor, no contexto de gestor do seu próprio negócio, evidencia-se também na sua capacidade de lidar com a adversidade. Nesse caso o ensino do empreendedorismo, pode ajudar a aprimorar tais características e habilidades, promovendo a aprendizagem empreendedora (FILLION, 1999, pg. 30).
\end{abstract}

$\mathrm{Na}$ análise da obra de McClelland, Fillion (1999, p. 81) apresenta um estudo do "sistema de valoração como referência básica para explicar o comportamento empreendedor, partindo do escopo que na história da humanidade as sociedades procuraram seguir os modelos de seus heróis". A capacidade empreendedora, portanto, pode ser tomada como um modelo de sucesso a ser seguido e instrumentalizado seja no universo acadêmico como organizacional.

Apesar de seu protagonismo nos estudos acerca dos aspectos comportamentais, David Mc Clelland sofreu críticas na época por embasar seus estudos num número restrito de fatores e por não considerar aspectos contextuais como por exemplo, os papéis das ideologias de cada Região, cultura e costumes, fatores que explicam o desenvolvimento das sociedades e civilizações, e também por não levar em conta as estruturas sociais que determinam as escolhas de cada indivíduo, ou seja, aspectos contingenciais, e também pela forma simplista de analisar o comportamento do empreendedor, usando como balizadores somente dois fatores de realização e poder (KRÜGER, 2017). Apesar disso, trouxe imensurável contribuição à ciência que estuda o fenômeno, pois mostrou que o ser humano é um produto social, um produto do meio e tende a reproduzir seus próprios modelos, suas próprias referências (MOTA, 2013). Para a autora, quanto mais empreendedores uma sociedade tiver, e maior for o valor dado a eles, maior será a quantidade de jovens que tenderão a imitá-los, incutindo na cultura da sociedade o espírito e as características peculiares do empreendedor. 
Já a análise de Fillion (1999) traz o que chama de grau de complexidade, por envolver questões sociais, econômicas, além de elementos promotores do estímulo empreendedor, como órgãos de fomento e pesquisa, por exemplo. Quanto maior forem os elementos que compõe um cenário de pesquisa, melhor será o resultado do perfil empreendedor de uma população. Além disso, outras características também devem ser analisadas para se compreender o contexto do empreendedorismo num local, como características econômicas e demográficas, contexto dos pequenos negócios, características gerenciais locais, oportunidades de negócio, desenvolvimento de negócios, capital de risco e financiamento de pequenos negócios, recuperação e aquisição, estratégias de crescimento, empreendedorismo em corporações ou intra-empreendedorismo, empresas familiares, incubadoras e sistema de apoio ao empreendedorismo, políticas governamentais, classes sociais específicas: mulheres, minorias, grupos étnicos e empreendedorismo, são temas que permeiam pesquisas e que podem ser utilizados para compreender melhor o cenário empreendedor de uma região.

\section{PESQUISA DE CAMPO}

Neste capítulo, são apresentados os resultados da pesquisa com os alunos dos cursos, das três instituições de ensino superior pesquisadas.

\subsection{Participantes - Unidades de análise}

As unidades de análise, segundo Sampieri, et.al (2013), constituem os participantes, objetos, eventos ou comunidades de estudo, que depende da formulação da pesquisa e dos alcances que o estudo pretende atingir. Para Richardson (2011), essa ideia sugere que a unidade de análise em geral é uma pessoa, mas também podem ser cidades, instituições, dentre outros. Tal enfoque traz coerência em se adotar o sujeito como unidade de análise, quando o foco de estudo relaciona-se ao seu comportamento, especificamente em relação às características e atitudes empreendedoras.

De acordo com o exposto no capítulo de aspectos metodológicos, os participantes desta pesquisa constituem três cursos de enfermagem, três instituições de ensino superior 
sendo duas privadas e uma pública e, as unidades de análise, os alunos ingressantes e concluintes desses três cursos. Optou-se pela amostragem por conveniência, visto que a abordagem do pesquisador com os alunos ocorreu de acordo com a facilidade de contato e de acordo com as disciplinas oferecidas nas turmas de ingressantes, cuja abordagem necessitava de prévia autorização do docente responsável. Já com relação aos alunos concluintes, foram feitas abordagens externas, de modo geral, nos espaços onde os alunos estavam na prática de estágio. Isso porque os últimos semestres dos cursos eram compostos por disciplinas de atividades de campo. A abordagem a estes alunos também envolveu autorização prévia dos docentes responsáveis, ou profissionais ligados diretamente com a atividade de estágio nos núcleos de saúde das cidades. O processo de organização para a coleta de dados destes alunos concluintes envolveu aspectos bastante burocráticos e que resultaram em entraves significantes para a pesquisa de campo. Tais aspectos serão melhor detalhados no capítulo de limitações e entraves da pesquisa, ao final deste trabalho.

A tabela a seguir apresenta o total de alunos de cada curso e o total de alunos pertencentes às instituições participantes:

\begin{tabular}{|c|l|l|}
\hline Instituição & Número total de alunos ingressantes & Número total de alunos concluintes \\
\hline Enf-1 & 130 alunos & 108 alunos \\
\hline Enf-2 & 140 alunos bacharel & 70 alunos bacharel \\
\hline Enf-3 & 55 alunos bacharel & 28 alunos bacharel \\
\hline
\end{tabular}

Quadro 21: Alunos participantes da pesquisa por curso

Fonte: Autora

A Tabela a seguir apresenta o total de alunos dos três cursos pesquisados e o total de alunos contemplados na pesquisa. O número total de alunos é o mesmo adotado na pesquisa quantitativa, foram considerados apenas alunos devidamente matriculados nos cursos, ou seja, foram desconsiderados os alunos que se encontravam em situação de trancamento, abandono ou transferência de matrícula: 


\begin{tabular}{|c|c|c|c|c|c|}
\hline Instituição & $\begin{array}{l}\text { Total } \\
\text { alunos }\end{array}$ & \multicolumn{3}{|c|}{ Participantes } & $\begin{array}{c}\text { amostra vs } \\
\text { universo }\end{array}$ \\
\hline \multirow{2}{*}{ Enf-1 } & \multirow{2}{*}{238} & \multirow{2}{*}{167} & Ingressantes & 114 & 114 de 130 \\
\hline & & & Concluintes & 53 & 53 de 108 \\
\hline \multirow{2}{*}{ Enf-2 } & \multirow{2}{*}{206} & \multirow{2}{*}{173} & Ingressantes & 120 & 120 de 140 \\
\hline & & & Concluintes & 53 & 53 de 66 \\
\hline \multirow{2}{*}{ Enf-3 } & \multirow{2}{*}{83} & \multirow{2}{*}{63} & Ingressantes & 43 & 43 de 55 \\
\hline & & & Concluintes & 20 & 20 de 28 \\
\hline
\end{tabular}

Quadro 22: Alunos participantes da pesquisa por curso - universo e amostra Fonte: Autora

\subsection{População e Amostra}

O tipo de amostragem utilizada para a coleta de dados dos alunos dos três cursos envolvidos na presente pesquisa é denominado amostragem por conveniência, como define Marconi e Lakatos (2004). A amostragem por conveniência é aquela em que o pesquisador aplica sua pesquisa, com base em condicionantes que favoreçam o contato direto entre pesquisador - pesquisado. Tal contato ocorreu por meio de abordagem direta do pesquisador, com os sujeitos respondentes, em situações de aula presencial, no caso dos ingressantes e, em campos de estágios, no caso dos concluintes, sendo este segundo grupo, em estabelecimentos de saúde da cidade como hospitais, unidades básicas de saúde ou mesmo nas dependências da escola.

De forma coordenada e planejada, foram aplicados os questionários aos alunos, iniciando a abordagem com uma breve leitura do Termo de Consentimento Livre e Esclarecido e entrega do questionário, que levou cerca de 6 minutos para ser respondido. Quando era possível, o aluno respondia no mesmo momento, quando não, era acertado entre pesquisador e participante um melhor dia e horário para fazer a retirada. $\mathrm{O}$ referido questionário também foi elaborado no formato digital, com o uso da plataforma online google.docs, forma utilizada, quando não era possível de o aluno responder na hora.

\subsection{Coleta de Dados}

A etapa de coleta de dados junto aos participantes da pesquisa pode ser considerada como um processo a parte, pois compreende um conjunto de passos exigidos para a 
sistematização de pesquisas que envolvem alunos das instituições de ensino dos cursos pesquisados. Atendendo aos critérios estabelecidos, a pesquisa passou por aprovação prévia da coordenação de graduação das instituições, após aprovação foi submetida ao comitê de ética institucional e, após parecer favorável, foi submetido à apreciação das coordenações de curso, que indicaram os docentes que poderiam auxiliar na aplicação da pesquisa, autorizando sua aplicação aos alunos, durante suas aulas. Os contatos entre pesquisador e docentes se deram via e-mail, conforme orientação das coordenações de curso.

O instrumento utilizado caracteriza-se como entrevista estruturada, elaborada por meio de questionário contendo 66 questões sendo:

\begin{tabular}{l} 
- Bloco 1: 10 Questões objetivas, com informações sócio-demográficas; \\
\hline - Bloco 2: 55 Questões objetivas, com conteúdo específico do perfil empreendedor; \\
\hline - 01 Questão discursiva: o que os alunos entendiam pelo termo “empreendedorismo". \\
Quadro 23: Conteúdos do Instrumento da pesquisa de campo \\
Fonte: Autora
\end{tabular}

A entrevista é um encontro profissional entre duas pessoas, com a finalidade de obtenção de informações por parte do pesquisador a respeito de determinado assunto. É uma técnica de coleta de dados bastante utilizada na investigação social, e apontada como eficaz para a obtenção de dados (MARCONI e LAKATOS, 2004). Para os autores, a pesquisa estruturada possui um roteiro previamente estabelecido de perguntas, cuja ordem permanece igual para todos os respondentes. Essa padronização permite obter respostas às mesmas perguntas, facilitando o processo de comparação entre elas, além de possibilitar uma análise estatística que auxilie na interpretação das informações coletadas. Na presente pesquisa, as perguntas foram fechadas e apenas uma pergunta aberta, permitindo não só uma análise estatística como também a análise qualitativa na interpretação das respostas que versaram sobre o entendimento do aluno em relação ao termo empreendedorismo.

No momento de aplicação da pesquisa junto aos alunos ingressantes dos cursos participantes, foi feita uma abordagem de apresentação da pesquisa, seus objetivos e espaço para que os alunos pudessem se manifestar sobre a apresentação feita. Logo após a apresentação, foi distribuído um kit contendo o Termo de Consentimento Livre e Esclarecido (TCLE), sendo uma via assinado pela pesquisadora e o instrumento de pesquisa contendo questionário e uma via do termo para o participante assinar. Foi solicitado a todos, leitura e 
assinatura do termo de consentimento e preenchimento do questionário de pesquisa, que levou uma média de 6 a 9 minutos. O referido TCLE consta dos anexos deste trabalho. Ao término, os participantes entregaram o termo de consentimento assinado junto com questionário à pesquisadora, que entregou a via do termo de consentimento assinada ao participante. O processo com alunos ingressantes dos três cursos pesquisados ocorreu dentro das salas de aula, na presença dos docentes responsáveis.

Já com os alunos concluintes, a coleta de dados ocorreu de forma pulverizada, tendo em vista que a maioria dos alunos se encontravam em disciplinas de campo prático, como hospitais, unidades básicas de saúde, escolas, etc. Esta dinâmica levou a etapa de coleta de dados num esquema individualizado, aluno por aluno, indo até os locais de estágio e realizando a abordagem com cada um deles, normalmente deixando num período e recolhendo em outro, para não comprometer suas atividades de trabalho.

A seguir serão apresentados os processos metodológicos das análises dos dados das pesquisas qualitativa e quantitativa.

\subsection{Análise dos dados da Pesquisa Qualitativa}

A análise dos dados de uma pesquisa qualitativa deve ser estruturada pelos procedimentos de organização, tratamento e interpretação dos dados coletados para compreendê-los, atender às questões de pesquisa e gerar conhecimento (SAMPIERI, et.al, 2013). Para os autores,

Os dados não são coisas isoladas, acontecimentos fixos, captados em um instante de observação. Eles se dão em um contexto fluente de relações: são - fenômenos\| que não se restringem às percepções sensíveis e aparentes, mas se manifestam em uma complexidade de oposições, de revelações e de ocultamentos. É preciso ultrapassar sua aparência imediata para descobrir sua essência. Na pesquisa qualitativa todos os fenômenos são igualmente importantes e preciosos: a constância das manifestações e sua ocasionalidade (SAMPIERI, et.al, 2013, p.84).

A pesquisa qualitativa neste trabalho ocorreu por meio de uma questão aberta do questionário com os dizeres: O que você entende pelo termo Empreendedorismo?

Especificamente nas ciências sociais, os estudos qualitativos podem fazer uso de diversos métodos estruturados em vários níveis de análise, cuja escolha segue o princípio da 
adequabilidade, ou seja, o que mais se adequa aos objetivos propostos (BARDIN, 1977). Dentre eles, evidenciam-se os métodos de análise de conteúdo, como alternativa útil para se estudar as falas ou respostas escritas, na tentativa de descrever e interpretar seus conteúdos e sentidos, e, em última análise, construir um mapa conceitual a partir de sua compreensão. A análise de conteúdo é estruturada a partir da frequência de aspectos similares entre as respostas e suas percepções sobre o fenômeno que está sendo estudado.

A análise de conteúdo, ainda segundo Bardin (1977), é um dos instrumentos mais úteis para a investigação de textos e é adaptável a um vasto campo de aplicação; ou seja, quaisquer comunicações escritas ou faladas são suscetíveis de serem decifradas pelas técnicas de análise de conteúdo. Bardin (1977) define análise de conteúdo como sendo um conjunto de técnicas de análise que visa obter, por procedimentos sistemáticos e objetivos de descrição do conteúdo das mensagens, indicadores (quantitativos ou não) que permitam a inferência de conhecimentos relativos às condições de produção destas mensagens.

Richardson (2011) entende a análise de conteúdo como sendo fundamental para pesquisas na área de ciências humanas e tem-se transformado em um mecanismo importante para o estudo da interação entre os indivíduos. Já para Minayo (2012), esta técnica proporciona ao pesquisador compreender o que está por trás das informações explicitadas nas respostas, podendo ir além das aparências do que está sendo comunicado.

A análise por categorias é uma forma muito utilizada na análise de conteúdo, por sua função de desmembramento dos textos em unidades, ou em categorias, criadas a partir da identificação de termos ou símbolos, em que faça sentido um reagrupamento (BARDIN, 1977). As categorias de análise, para Bardin (1977), podem ser criadas a priori, ou seja, a partir da teoria e antes da coleta dos dados, ou a posteriori, quando já se tem a pesquisa aplicada e os dados coletados. Ainda para o autor, a análise categorial exige inicialmente uma classificação de elementos em suas características pré-definidas, para assim reorganizar um reagrupamento, em que as categorias reúnem grupos de elementos com características comuns. Para tanto, optou-se pela análise de enunciação. Essa técnica de análise de enunciação busca compreender o significado das respostas, por meio do conteúdo ou enunciado do participante. É o processo de segmentar os textos das respostas, em unidades 
menores, suscintas, podendo ser orações, sentenças, parágrafos ou tópicos, de modo que se possa segmentar o texto, reduzindo-o para o mais simples e curto possível.

A análise de conteúdo, por meio da técnica de análise por enunciação, em si, já se caracteriza como categoria de análise a posteriori, utilizando os dados coletados na pesquisa, por entender que as respostas poderiam apontar elementos diversificados, possibilitando uma análise mais imersiva (MINELLO, 2014).

O processo de imersão do conteúdo é composto por três fases: codificação inicial ou enunciação, categorização e inferência. A etapa de codificação inicial deu-se por meio de leitura flutuante, buscando identificar unidades de registro, ou padrões de resposta para se criar as codificações iniciais. O processo de leitura flutuante ocorre no momento em que o pesquisador começa a conhecer e se ambientar com os textos provenientes das respostas dos participantes (BARDIN, 1977). Segundo a autora, o termo flutuante é uma analogia a atitude do psicanalista, pois pouco a pouco, esta leitura dos textos das respostas se torna mais precisa, em função de hipóteses que vão se constituindo e com base nas teorias que sustentam o material. Já para Richardson (2011), a leitura flutuante possibilita que o pesquisador tenha um contato inicial com o material, dessa maneira, conhecendo a estrutura da narrativa, tendo as primeiras impressões em relação às mensagens produzidas, dando contexto a um processo de amadurecimento na compreensão das respostas para o cenário da pesquisa.

Com base na leitura flutuante e de posse de códigos, símbolos e termos que já foram minerados, o pesquisador se insere num processo sistêmico de categorização desse conteúdo de entrada de dados, memorização e interpretação, identificando repetições, busca de padrões e construção de mapa conceitual dos padrões estabelecidos (MINAYO, 2012). Com o referido processo de análise de conteúdo, foi possível determinar o esquema denominado nuvem de palavras, método que consiste na categorização dos termos localizados em maior quantidade, ou padrões, sinalizando as percepções dos respondentes e promovendo a construção de infogramas a partir deste levantamento (PRAIS e ROSA, 2017).

Na fase de inferência, última etapa do processo de análise de conteúdo, os grupos, ou conjunto de termos são analisados com base na teoria, dando sentindo à interpretação e 
enriquecendo o texto com as contribuições de estudiosos do tema. Para Triviños (1987) esse processo de análise de conteúdo é composto por um conjunto de técnicas, exigindo do pesquisador um apropriado domínio do conteúdo estudado. A discussão dos resultados deste processo, portanto, recorreu à técnica de proposições teóricas, trazendo as falas de estudiosos que tratam das especificidades do tema, buscando trazer confiabilidade aos resultados da pesquisa.

O esquema a seguir sintetiza este processo da pesquisa qualitativa:

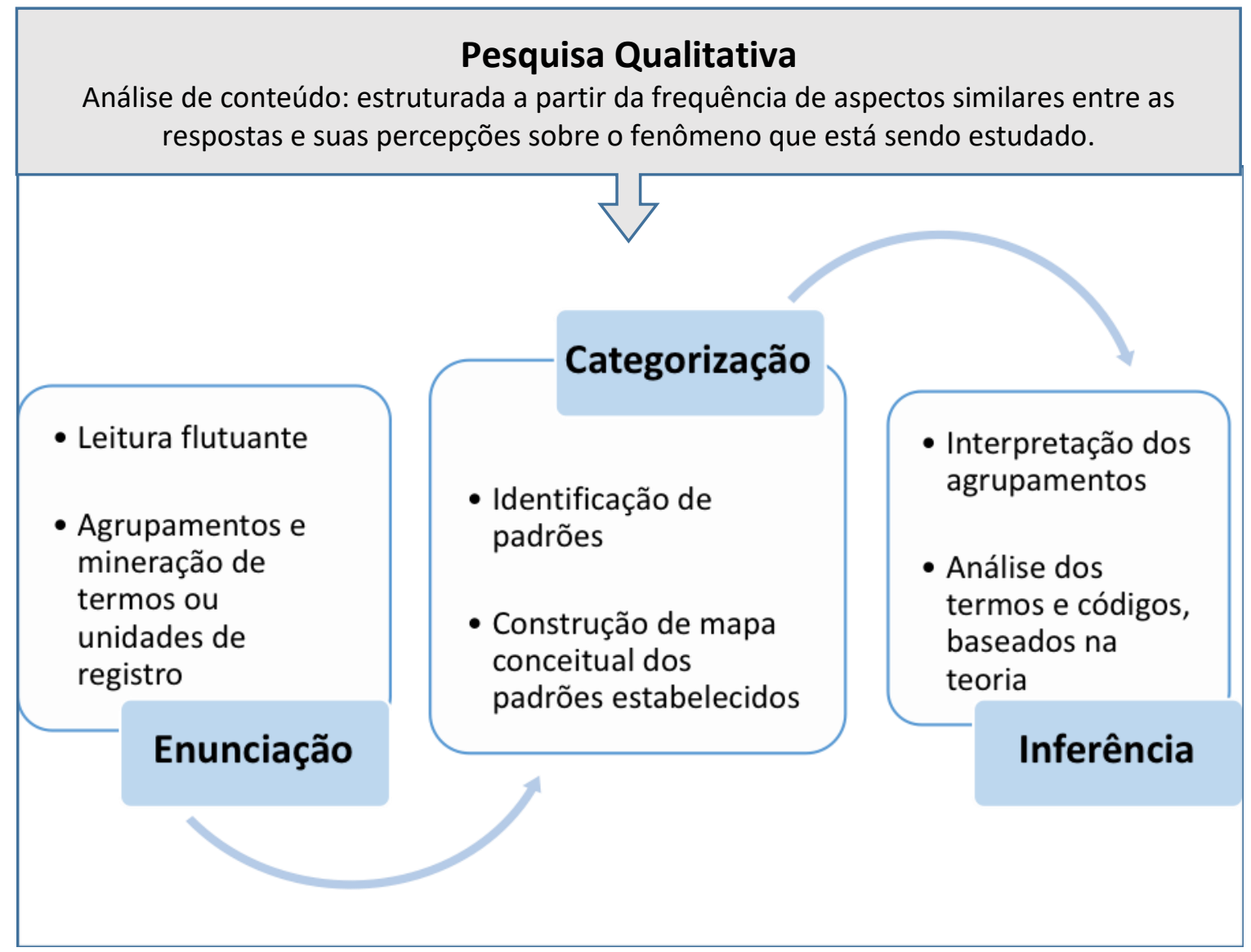

Figura 4: Aspectos procedimentais da Pesquisa Qualitativa Fonte: Autora

Após a apresentação da abordagem qualitativa da presente pesquisa, apresenta-se a seguir, o processo metodológico das análises dos dados da pesquisa quantitativa. Como já mencionado, a aplicação de pesquisa de natureza quanti-quali contribui para a ampliação do conhecimento sobre os resultados obtidos pois permite uma triangulação dos dados que, segundo Triviños (1987), favorece um aprofundamento sobre o tema investigado e faça um cruzamento de suas conclusões, de modo a ter maior confiança nos resultados. Para 
Coutinho (2011), a triangulação de dados consiste em combinar dois ou mais elementos, fontes de dados, abordagens teóricas, numa mesma pesquisa para que se possa obter como resultado final um retrato mais fidedigno da realidade ou uma compreensão mais profunda do fenômeno analisado.

\subsection{Análise dos dados da Pesquisa Quantitativa}

Como dito anteriormente, a pesquisa quantitativa neste trabalho se faz necessária em virtude do tipo de pesquisa que foi aplicada e em virtude de seus propósitos, quais sejam, descrever e/comparar características de grupos sociais, realidades, contextos ou instituições, ou também, estabelecer relações causais (RAMOS, 2013). A pesquisa quantitativa também é adequada quando do uso de um instrumento de pesquisa em formato de questionário objetivo que resulte em dados numéricos, em que as análises quanti precisem ser aplicadas. Por meio desses números, a presente pesquisa se propõe analisar as características comportamentais empreendedoras de discentes ingressantes e concluintes dos três cursos de enfermagem pesquisados e contribuir para verificar possíveis relações entre os cursos e entre os alunos, por meio de testes estatísticos que validem a cientificidade dos resultados.

O número total de alunos é o mesmo adotado na pesquisa quantitativa. Foram considerados apenas alunos devidamente matriculados nos cursos, isto é, foram desconsiderados os alunos que se encontravam em situação de trancamento, abandono ou transferência de matrícula.

$\mathrm{Na}$ coleta dos dados da pesquisa quantitativa, utilizou-se um questionário, já apresentado no capítulo de referencial teórico, desenvolvido por David McClelland e já validado anteriormente por outros pesquisadores. O instrumento também é utilizado há duas décadas pelo SEBRAE, em um evento institucional denominado EMPRETEC, como já mencionado anteriormente. Tal instrumento objetiva identificar as características comportamentais empreendedoras, CCE's, dos discentes ingressantes e concluintes dos três cursos pesquisados. Este questionário é baseado nas 10 CCE's de McClelland (1987), composto por 55 afirmações, mais 1 questões referentes às questões sócio-demográficas. 0 instrumento foi respondido por discentes ingressantes e concluintes, de acordo com uma 
escala de 5 pontos Likert, correspondendo a seguinte gradação: 1 = Discordo plenamente, 2 $=$ Discordo parcialmente, 3 = Não sei opinar, $4=$ Concordo parcialmente e $5=$ Concordo plenamente. De acordo com sua percepção, diante de cada uma das assertivas que compõem o instrumento da seguinte forma:

\begin{tabular}{|c|c|c|c|c|c|c|}
\hline CCE & \multicolumn{7}{|c|}{ QUEST̃̃S } \\
\hline Busca de oportunidades e iniciativa & Q1 & Q12 & Q23 & Q34* $^{*}$ & Q45 & FC \\
\hline Persistência & Q2 & Q13 & Q24 & Q35* $^{*}$ & Q46 & FC \\
\hline Comprometimento & Q3 & Q14 & Q25 & Q36 & Q47* & FC \\
\hline Exigência de qualidade e eficiência & Q4 & Q15 & Q26 & Q37 & Q48 & - \\
\hline Correr riscos calculados & Q5 & Q16 & Q27 & Q38* $^{*}$ & Q49 & FC \\
\hline Estabelecimento de metas & Q6 & Q17* & Q28 & Q39 & Q50 & FC \\
\hline Busca de informações & Q7 & Q18 & Q29* & Q40 & Q51 & FC \\
\hline Planejamento e monitoramento sistemáticos & Q8 & Q19 & Q30 & Q41* & Q52 & FC \\
\hline Persuasão e redes de contato & Q9 & Q20* & Q31 & Q42 & Q53 & FC \\
\hline Independência e autoconfiança & Q10 & Q21* & Q32 & Q43 & Q54 & FC \\
\hline
\end{tabular}

Quadro 24: Questões e características do instrumento das CCE's Fonte: McClelland (1987)

Os $\left({ }^{*}\right)$ do quadro correspondem às questões negativas em que a pontuação deve ser subtraída do resultado final da respectiva característica e deve-se acrescentar 6 (seis) pontos ao final do somatório. As questões de número 11, 22, 33, 44 e 55 correspondem ao "Fator de Correção", utilizado para evitar que, muitas vezes de modo inconsciente, o respondente apresente uma autoimagem excessivamente favorável. O Fator de Correção é utilizado se o somatório da pontuação dessas questões for igual ou superior a 20 (vinte) pontos. Se isso ocorrer, todas as CCE's devem ser corrigidas com a subtração dos pontos correspondentes (MANSFIELD et.al, 1987).

O quadro a seguir, apresenta o fator de correção para as CCE's:

\begin{tabular}{|c|c|}
\hline \multicolumn{2}{|c|}{ FATOR DE CORREÇÃO } \\
\hline Se o a pontuação do Fator de Correção for... & $\begin{array}{c}\text {... subtraia o número de correção da } \\
\text { pontuação total de cada competência }\end{array}$ \\
\hline 24 ou 25 & 7 \\
\hline 22 ou 23 & 5 \\
\hline 20 ou 21 & 3 \\
\hline 19 ou menos & 0 \\
\hline
\end{tabular}

Quadro 25: Fator de correção das CCE's

Fonte: Mansfield et al. (1987). 
Após a etapa de aplicação do instrumento de pesquisa junto aos alunos participantes dos três cursos, os dados dos questionários foram digitados numa plataforma de google.docs. Após a alimentação do formulário online, os dados passaram por conferência e logo após a conferência, os dados foram compilados e salvos em planilhas Excel, separadas por curso. Para tratamento e análise desses dados compilados, foi utilizado o software Statistical Packagefor the Social Sciences - SPSS ${ }^{\circledR}$. Nessa ocasião foram analisados quantitativamente e explorados os dados dos modelos propostos por McClelland, levando em conta as características comportamentais empreendedoras, também denominadas como dimensões do perfil empreendedor (MANSFIELD et al., 1987).

Para cada um dos instrumentos de pesquisa, na fase denominada descrição analítica, foram calculados mínimo, máximo, médias e o desvio padrão de cada característica. Em seguida, para estimar a confiabilidade, foi medida a consistência interna por meio do Coeficiente Alfa de Cronbach (SAMPIERI et.al, 2013). O valor do Coeficiente Alfa de Cronbach pode variar de 0 a 1 , sendo que, quanto mais próximo de 1 , melhor a confiabilidade atribuída, pois, maior será a consistência interna do instrumento ou maior a congruência entre os itens, indicando a homogeneidade da medida do mesmo fenômeno (MATTHIENSEN, 2011).

O Alfa de Cronbach é calculado pela seguinte Equação: $\alpha=\frac{k}{k-1}\left[\frac{\sigma_{\tau}^{2}-\Sigma_{i=1 \sigma_{i}^{2}}^{k}}{\sigma_{\tau}^{2}}\right]$ onde:

- k corresponde ao número de itens do questionário;

- $\sigma^{\wedge} 2 \mathrm{i}$ corresponde soma das variâncias de cada item;

- $\sigma^{\wedge} 2 t$ corresponde a variância total do questionário, determinada como a soma de todas as variâncias.

O Alfa de Cronbach para as CCE's obteve $\alpha=0,799$. Deste modo, os valores resultantes da aplicação dos questionários com os 403 participantes da pesquisa são confiáveis (MATTHIENSEN, 2011).

Foram realizadas, ainda, análises comparativas dos resultados das características entre alunos ingressantes e concluintes da mesma instituição, apenas ingressantes e apenas concluintes dos três cursos, buscando diagnosticar possíveis diferenças entre os resultados que pudessem apontar perfis empreendedores diferentes. 
A seguir, é apresentado o esquema de análises de triangulação dos resultados das pesquisas qualitativas e quantitativas.

\subsection{Triangulação}

A técnica de triangulação de dados, para este estudo, tem por finalidade confrontar os resultados da pesquisa qualitativa com dados da pesquisa quantitativa, buscando estabelecer ligações entre as descobertas obtidas nas pesquisas de modo isolado. Tem ainda a função, segundo Vergara (2015), de reduzir os riscos de viés nas conclusões dos estudos ou até limitações próprias de um método, levando a resultados de maior credibilidade. $\mathrm{Na}$ mesma linha, Yin (2015) considera a triangulação de dados de resultados específicos uma boa forma de mapear a pesquisa, proporcionando novas descobertas e enriquecendo o trabalho, além, do crédito à pesquisa, corroborando resultados ou apontando discrepâncias antes não vistas. Segundo o autor, uma hipótese testada com recursos de diferentes métodos pode ser considerada mais válida que uma hipótese testada por um único método. Além disso, a triangulação pode promover novas respostas, podendo apresentar outros tipos de resultados além dos que já foram levantados.

Para Patton (2002), a técnica de triangulação de dados pode ser aplicada nas seguintes situações: por meio de perspectivas para o mesmo conjunto de dados (triangulação da teoria); por meio das fontes de dados (triangulação de dados); entre avaliadores (triangulação do investigador); e por meio dos métodos (triangulação metodológica). Neste estudo, optou-se pela técnica de triangulação de dados com aporte teórico, que para Patton (2002) e Zappellini e Feuerschüte (2015), é um estudo de combinação de métodos, tanto quantitativos como qualitativos, discutindo-os por meio de discussões teóricas também chamada de triangulação simultânea, quando do uso dessa triangulação para o estudo.

A imagem a seguir ilustra esta etapa do estudo: 


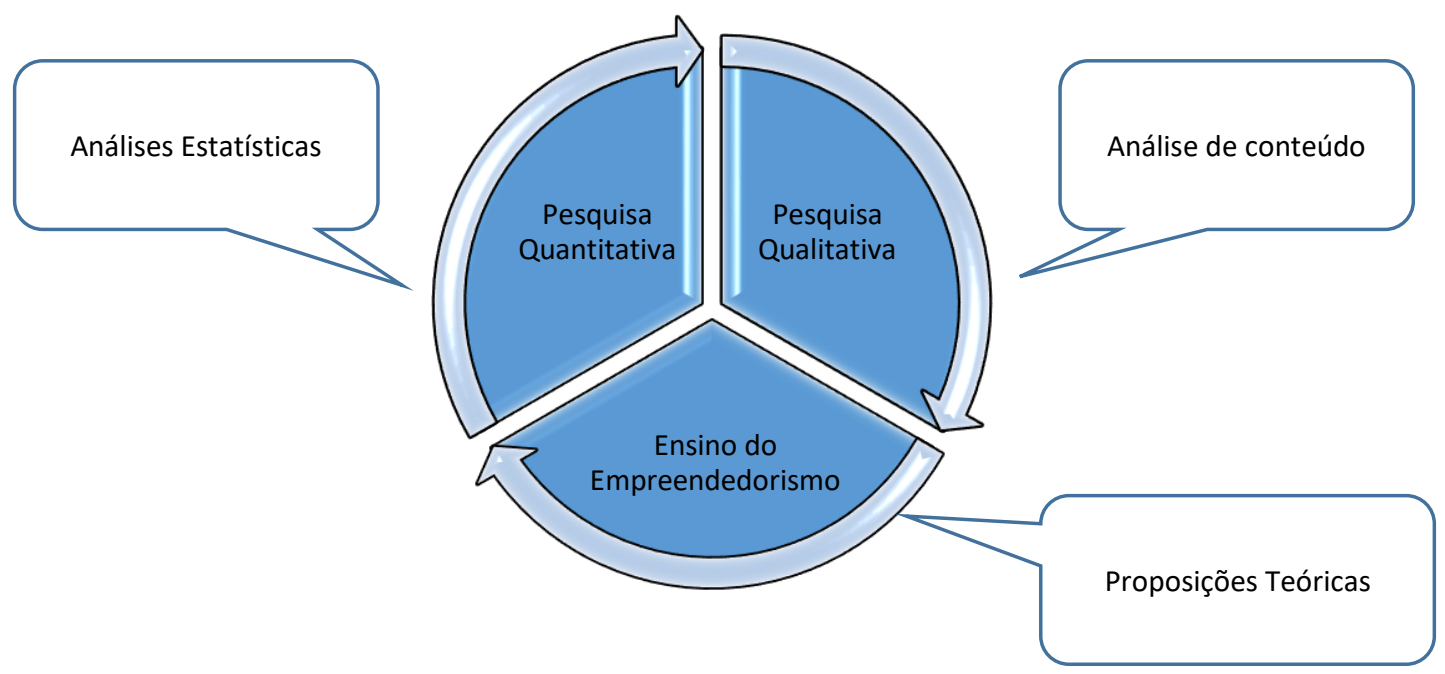

Figura 5: Aspectos do processo de triangulação da pesquisa

Fonte: autora

O processo de triangulação servirá para validar ou ampliar as interpretações feitas pelas análises isoladas. Para isso, são adotadas diferentes percepções para esclarecer o significado por meio da repetição das observações ou interpretações. No entanto, sabendose que nenhuma observação ou interpretação se repete singularmente, a triangulação serve também para clarificar significados pela identificação das diferentes maneiras pelas quais uma pesquisa é vista, podendo resultar em forma de três perspectivas distintas (ZAPPELLINI e FEUERSCHÜTE, 2015), a saber:

a. Convergência de resultados: os resultados das pesquisas qualitativa e quantitativa confirmam parcial ou totalmente uns aos outros;

b. Complementação: aqui, os resultados se concentram em diferentes aspectos da questão de pesquisa, e, por serem complementares, permitem visualizar um quadro mais amplo da realidade investigada;

c. Divergência ou contradição: os dados obtidos por uma metodologia de pesquisa podem ser distintos daqueles coletados com a outra, exigindo um novo estudo que esclareça teórica ou empiricamente a divergência e dê conta das razões e motivações por trás dela (ZAPPELLINI e FEUERSCHÜTE, 2015).

A seguir, é apresentado a análise dos resultados do presente processo de pesquisa. 


\section{ANÁLISE DOS RESULTADOS}

Neste capítulo são analisados os resultados obtidos no estudo, os quais são apresentados em três etapas:

1. Análise da abordagem quantitativa;

2. Análise da abordagem qualitativa;

3. Triangulação dos dados.

\subsection{Análise da Abordagem Quantitativa}

Trazendo novamente os números da pesquisa, do universo de 527 alunos dos três cursos pesquisados, obteve-se uma amostra de 76,6\%, 403 alunos participantes. Destes 403 participantes, 167 são do curso denominado Enf-1 (sendo 114 ingressantes e 53 concluintes), 173 são do curso Enf-2 (sendo 120 ingressantes e 53 concluintes) e 63 são do curso Enf-3 (43 ingressantes e 20 concluintes). Do total de participantes, 277 alunos são ingressantes, o que corresponde a $68,73 \%$ da amostra e 126 alunos são concluintes, correspondendo a $31,27 \%$ do total da amostra, conforme a figura a seguir:

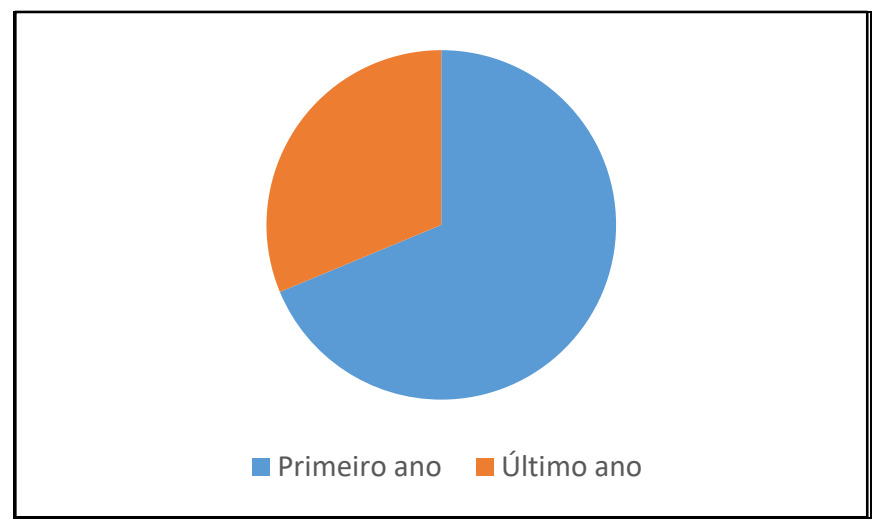

Gráfico 7: Porcentual de alunos ingressantes e concluintes Fonte: Autora

A média de idade dos participantes é de 23 anos, sendo a idade mínima de 18 anos e a idade máxima de 50 anos. Em relação à raça/cor, tem-se: amarela com 15 participantes, que equivale a 3,72\%; branca com 245 participantes, que equivale a 60,79\%; negra com 46 participantes, que equivale a $11,41 \%$; parda com 94 participantes, que equivale a $23,33 \%$ e não declarada com 3 participantes, que equivale a $0,74 \%$. 


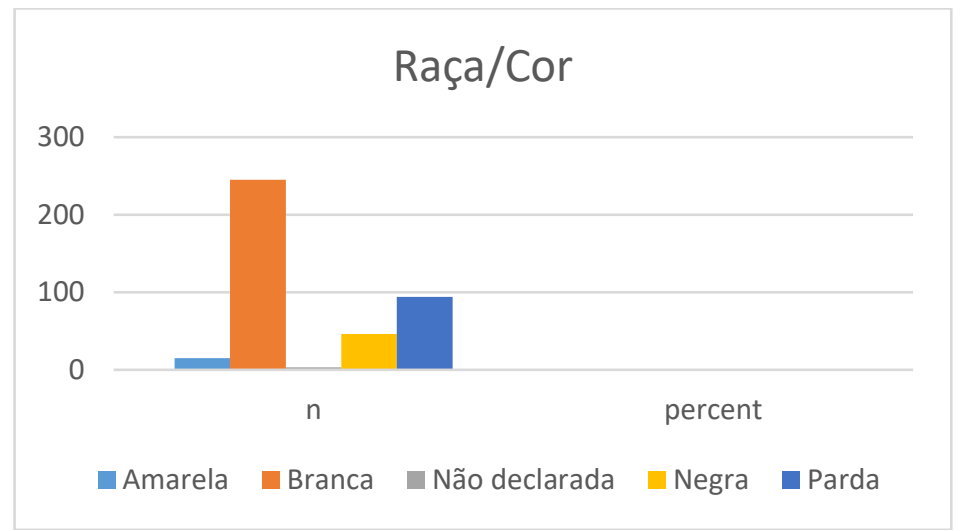

Gráfico 8: Porcentual de alunos em relação à raça e cor Fonte: Autora

No que diz respeito ao estado civil, tem-se: solteiros com 353 participantes, que equivale a 87,59\%; casados com 37 participantes, que equivale a 9,18\%; consensual com 6 participantes, que equivale a 1,49\%; separados com 5 participantes, que equivale a 1,24\%; viúvo com 1 participante, que equivale a 0,25\%; outro com 1 participante, que equivale também a $0,25 \%$, conforme gráfico a seguir:

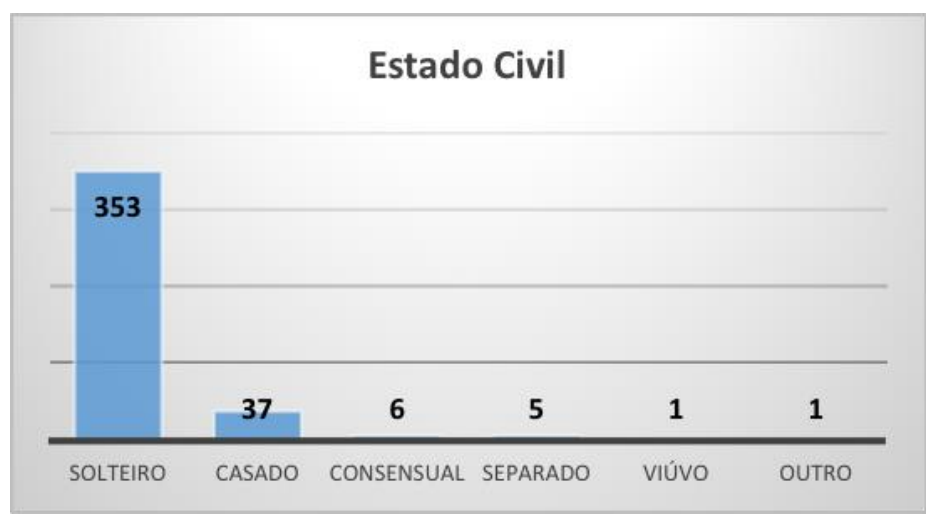

Gráfico 9: Porcentual de alunos em relação ao estado civil Fonte: Autora

Quanto ao gênero, 336 participantes são mulheres, somando 83,37\% e 67 são homens, somando $16,63 \%$, conforme gráfico a seguir: 


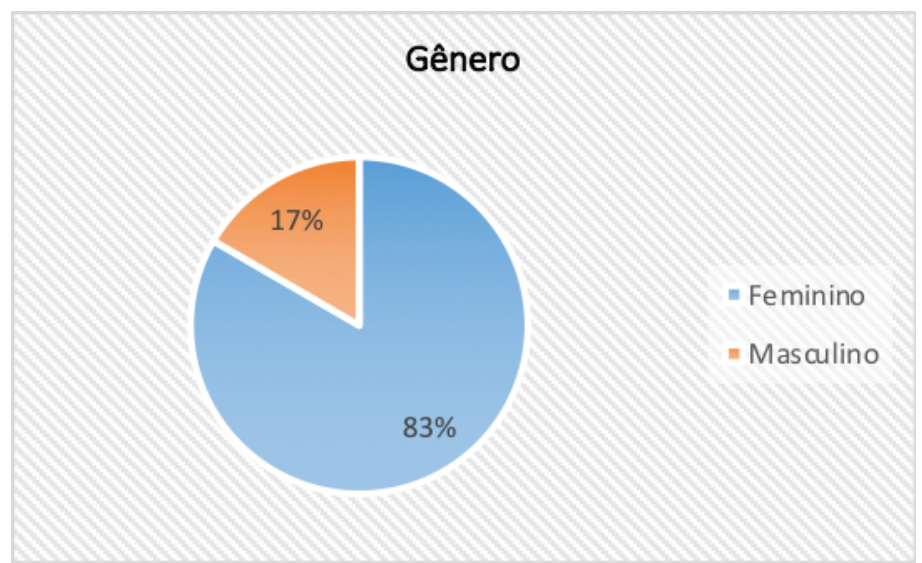

Gráfico 10: Porcentual de alunos em relação à gênero Fonte: Autora

Em relação a quantidade de filhos, 348 participantes declararam não ter filhos, que equivale a 86,35\%; 34 participantes declararam ter 1 filho, o que equivale a 8,44\%; 16 participantes declararam ter 2 filhos, o que equivale a 3,97\%; 4 participantes declararam ter 3 filhos, o que equivale a 0,99\% e 1 participante declarou ter 5 filhos, o que equivale a 0,25\%, conforme quadro a seguir:

\begin{tabular}{|c|c|c|}
\hline Quantidade filhos & No. Participantes & Percentual \\
\hline 0 & 348 & $86,35 \%$ \\
\hline 1 & 34 & $8,44 \%$ \\
\hline 2 & 16 & $3,97 \%$ \\
\hline 3 & 4 & $0,99 \%$ \\
\hline 5 & 1 & $0,25 \%$ \\
\hline
\end{tabular}

Quadro 26: Quadro de porcentual de alunos em relação ao número de filhos Fonte: autora

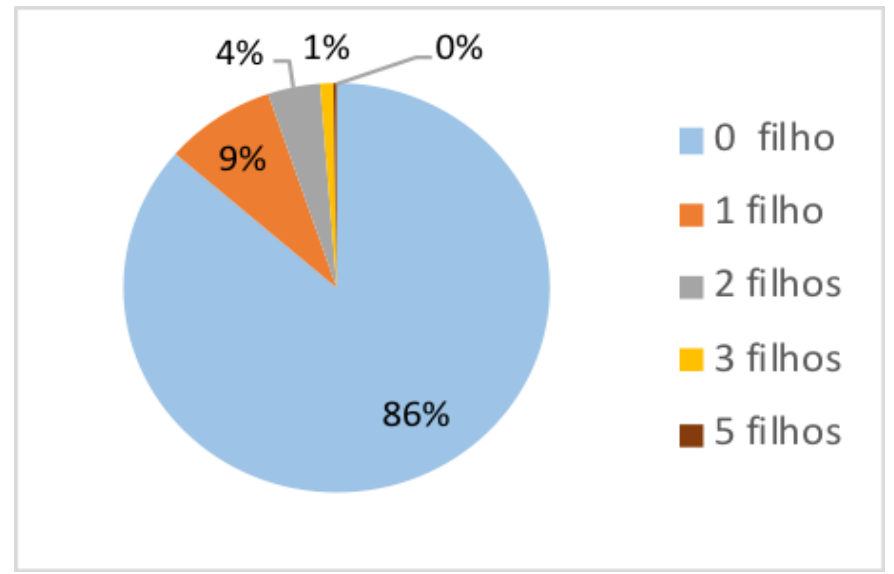

Gráfico 11: Porcentual de alunos em relação à gênero Fonte: Autora 
Em relação ao número de filhos, uma análise foi feita sob os estudos de diagrama de dispersão, que segundo Morettin e Bussab (2010), são análises estatísticas baseadas em uma ou mais variáveis para exibir valores de um conjunto de dados, apresentados em uma coleção de pontos, cada um com o valor de uma variável determinando a posição no eixo horizontal e o valor da outra variável determinando a posição no eixo vertical. Os diagramas de dispersão, ou gráficos de dispersão, são usados para verificar se existe relação de causa e efeito entre duas variáveis de natureza quantitativa, não sendo usado para provar que uma variável afeta outra, mas para determinar se existe relação entre elas e qual a intensidade dessa relação. Pelos resultados dos pontos, pode-se aferir como, ou quanto, a dispersão foi apontada. Existem cinco tipos de análises para os desenhos de dispersão: a correlação positiva indica uma tendência crescente entre os pontos, ou seja, conforme uma variável aumenta, a outra variável também aumenta proporcionalmente (STASINOPOULOS e RIGBY, 2007).

A correlação negativa indica o inverno, ou seja, quando os pontos se concentram em uma linha decrescente, mostrando que enquanto uma variável aumenta, outra diminui. A correlação perfeita ocorre quando não há uma grande dispersão entre os pontos, ou seja, será total, independente da tendência. Na correlação forte, quanto menor for a dispersão dos pontos, maior será a correlação entre os dados. Com isso, podemos identificar como forte quando os dados estão bem próximos, altamente concentrados. Ainda, na correlação forte, quanto maior for a dispersão dos pontos, menor será o grau de correlação entre os dados, ilustrando que eles praticamente não possuem correlação (MORETTIN E BUSSAB, 2010).

Os diagramas analisados na figura a seguir trazem de maneira individualizada as variáveis "quantidade de filhos" e as "características comportamentais empreendedoras" numa coordenada e os valores das pontuações na outra: 

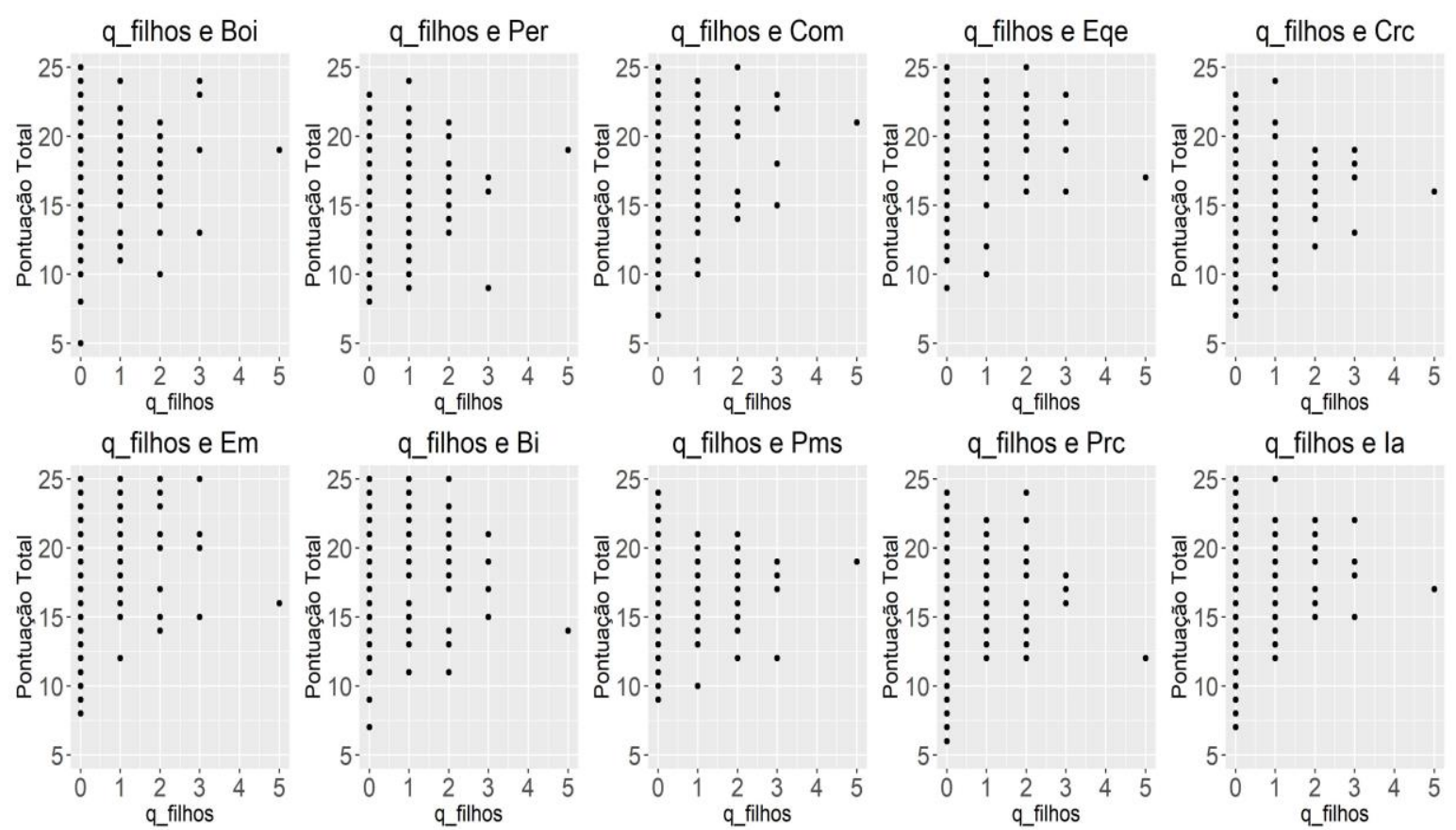

Gráfico 12: Gráfico de dispersão - variáveis: número de filhos e CCE's Fonte: Autora

Diante do que diz a teoria, pode-se aferir que, de um modo geral, quanto maior o número de filhos, melhores os resultados das características comportamentais empreendedoras, o que leva a duas interpretações: a dispersão tem como resultado a correlação positiva (conforme uma variável aumenta, a outra variável também aumenta proporcionalmente), e outra conclusão a ser considerada refere-se ao fato de os alunos mais velhos serem os alunos concluintes dos cursos, o que pode significar que houve avanço no entendimento desses em relação às características empreendedoras. O raciocínio centra-se na forma com que os pontos de comportam nos diagramas (MORETTIN E BUSSAB, 2010). Observa-se que os pontos se afunilam, subindo os graus do eixo " $x$ " (pontuação das CCE's), mostrando que os indivíduos que possuem mais filhos tendem a apresentar resultados maiores em relação ao instrumento de pesquisa aplicado. A dispersão dos indivíduos que não têm nenhum filho é muito maior que a dispersão dos indivíduos que possuem 2, 3 filhos.

Nota-se, também, que houve ampla dispersão - quase no total da escala - com participantes que não possuem filhos e conforme a quantidade de filhos aumenta, há uma tendência de aumentar o número da escala de pontos das características empreendedoras. As características comportamentais que aparecem nesta análise, em maior evidência são "correr riscos calculados" e "independência e autoconfiança”, características individuais 
bastante relacionados com responsabilidade e maturidade, que por sua vez se relacionam com os papéis desempenhados por pais e mães na manutenção da família, tendo em vista os compromissos que a constituição familiar, em tese, impõe.

As demais características se mantiveram num padrão mais homogêneo, com correlação fraca, que, segundo a teoria, significa que, quanto maior for a dispersão dos pontos, menor será o grau de correlação entre os dados, podendo dizer que resultaram em correlação fraca, com tendência a correlação positiva (STASINOPOULOS e RIGBY, 2007).

Esta constatação converge com as ideias de Torres (2018) e Leal (2009), que pesquisou o processo do treinamento do Seminário Empretec do Sebrae, em sua pesquisa de mestrado, a qual pôde acompanhar os participantes e seus resultados quanto ao progresso no perfil empreendedor. Fonseca e Muylder (2010) também descrevem em sua pesquisa sobre o desempenho dos participantes do seminário Empretec, que o nível de maturidade dos participantes era percebido nos resultados das ações, que demonstravam conscientização maior por parte dos participantes e isso lhes garantia melhores resultados no processo de aprendizagem e na prática das atividades.

O mesmo pode ser usado para o gráfico a seguir que traz a dispersão dos dados considerando as variáveis idade e as características comportamentais empreendedoras. A análise de dispersão conta com alto grau de interpretação do pesquisador pois a compreensão parte de uma imagem onde os pontos representantes dos sujeitos apresentam-se no gráfico de modo a apontar algum tipo de padrão de dispersão que faça sentido para o pesquisador. Neste caso da análise de idade com as CCE's o que se pode aferir é que a idade do indivíduo, em algumas características, eleva a pontuação para níveis mais altos, como é o caso das características "Comprometimento", "Exigência de qualidade e eficiência" e "Estabelecimento de metas" e "Busca de informações", que mostram um agrupamento de pontos muito acima do padrão médio identificado pelos cálculos gerais, levando em conta a interpretação recomendada pela teoria (MORETTIN E BUSSAB, 2010). 

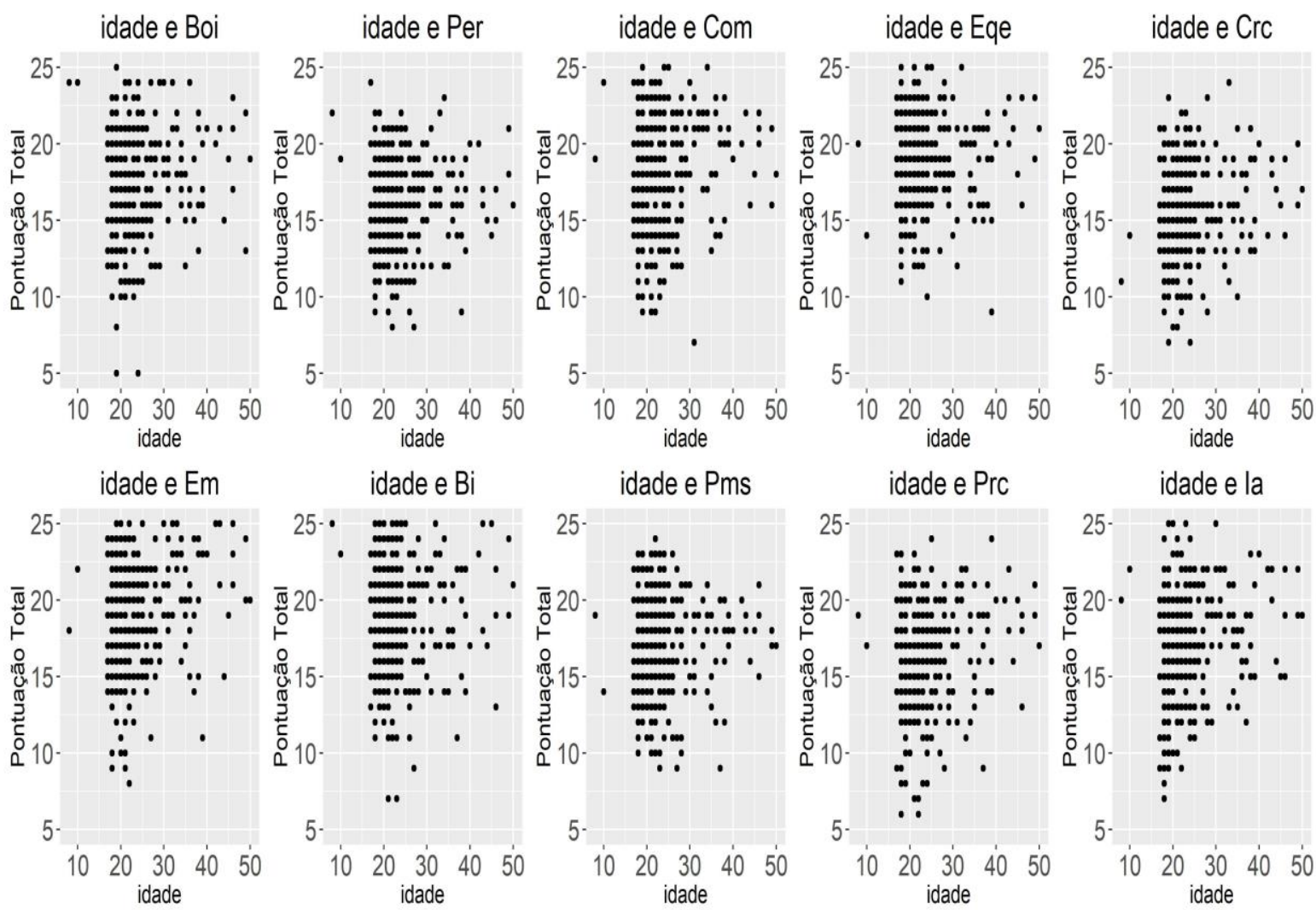

Gráfico 13: Gráfico de dispersão - variáveis: idade vs CCE's Fonte: Autora

Já as características "persistência", "planejamento e monitoramento sistemáticos" e "correr riscos calculados" mostraram uma concentração mediana em termos de pontuação dos indivíduos, o que retrata com maior proximidade os resultados das análises descritivas, que apontaram números entre 16 e 18 pontos na média dos resultados. Constata-se também que os blocos de concentração dos pontos nos diagramas das características movem-se na escala de pontos da coordenada " $x$ " ficando entre 10 e 20 nas características "persistência", "correr riscos calculados", e "planejamento e monitoramento sistemático", já os demais mantém concentração de pontos numa escala um pouco maior, ficando entre 12 e 22, em idades de 20 a 30 anos.

Também foi perguntado aos participantes se possuíam empreendedores na família e as opções de respostas continham pais, irmãos, tios, primos e nenhum parente na família. Sendo assim, quando perguntado se tinham empreendedor na família, 13 participantes responderam "irmãos", o que corresponde a 3,23\% do total, 107 participantes responderam "pai ou mãe", o que corresponde a 26,55\% do total, "primos" foram 19 participantes, correspondendo a 4,71\%, "tios" como empreendedores foram 77 participantes, 
correspondendo a 19,11\% do total e "não tinham nenhum empreendedor na família" foram 187 participantes, o que equivale a $46,40 \%$ do total de respondentes. Pode-se constatar que cerca de metade dos participantes não possuem empreendedor na família, como pode ser visto no quadro e no gráfico a seguir:

\begin{tabular}{|c|c|c|}
\hline Empreendedor na família & No. Participantes & Percentual \\
\hline Irmão(s) & 13 & $3,23 \%$ \\
\hline Nenhum & 187 & $46,40 \%$ \\
\hline Pai ou mãe & 107 & $26,55 \%$ \\
\hline Primo(s) & 19 & $4,71 \%$ \\
\hline Tio(s) & 77 & $19,11 \%$ \\
\hline
\end{tabular}

Quadro 27: Porcentual de alunos em relação à empreendedores na família Fonte: autora

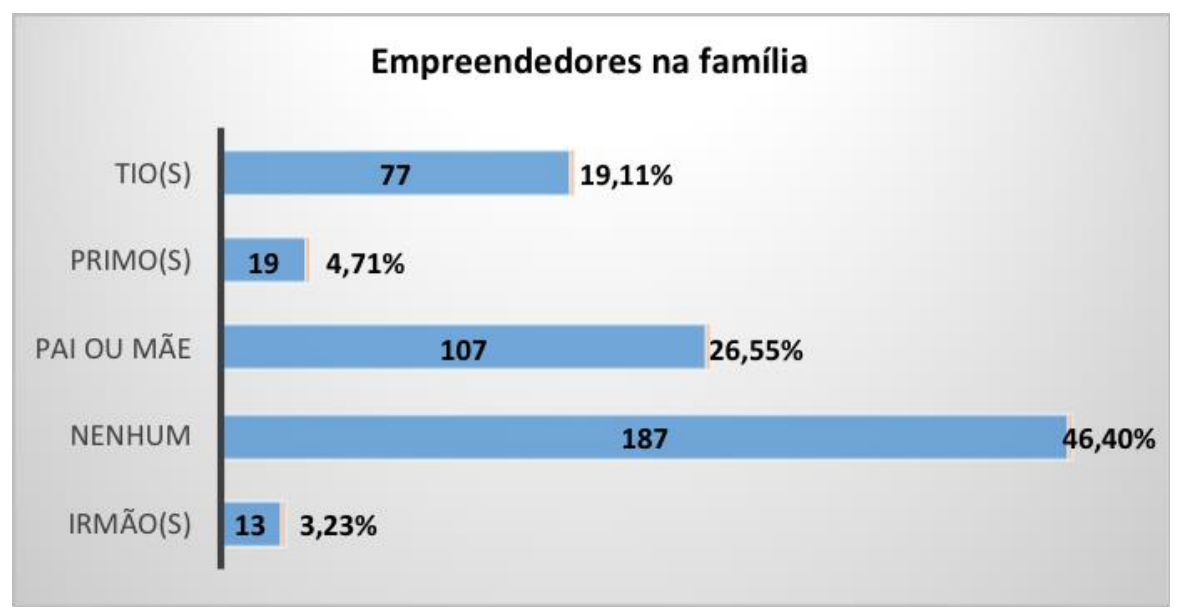

Gráfico 14: Porcentual de alunos em relação à empreendedores na família Fonte: autora

Quando agrupados em parentes de 1‥ e 2‥ graus, "não tem" manteve-se em 187, "parentes de 1ㅇ. grau" foram 120 participantes e "parentes de 2․ grau foram 96 participantes, conforme quadro e figura a seguir:

\begin{tabular}{|c|c|c|}
\hline Empreendedor na família & No. Participantes & Percentual \\
\hline Parentes 1‥ Grau & 120 & $29,78 \%$ \\
\hline Parentes 2‥ Grau & 96 & $23,82 \%$ \\
\hline Não tem & 187 & $46,40 \%$ \\
\hline
\end{tabular}

Quadro 28: Porcentual de alunos em relação à empreendedores na família - 10. e 2‥ Graus Fonte: autora 


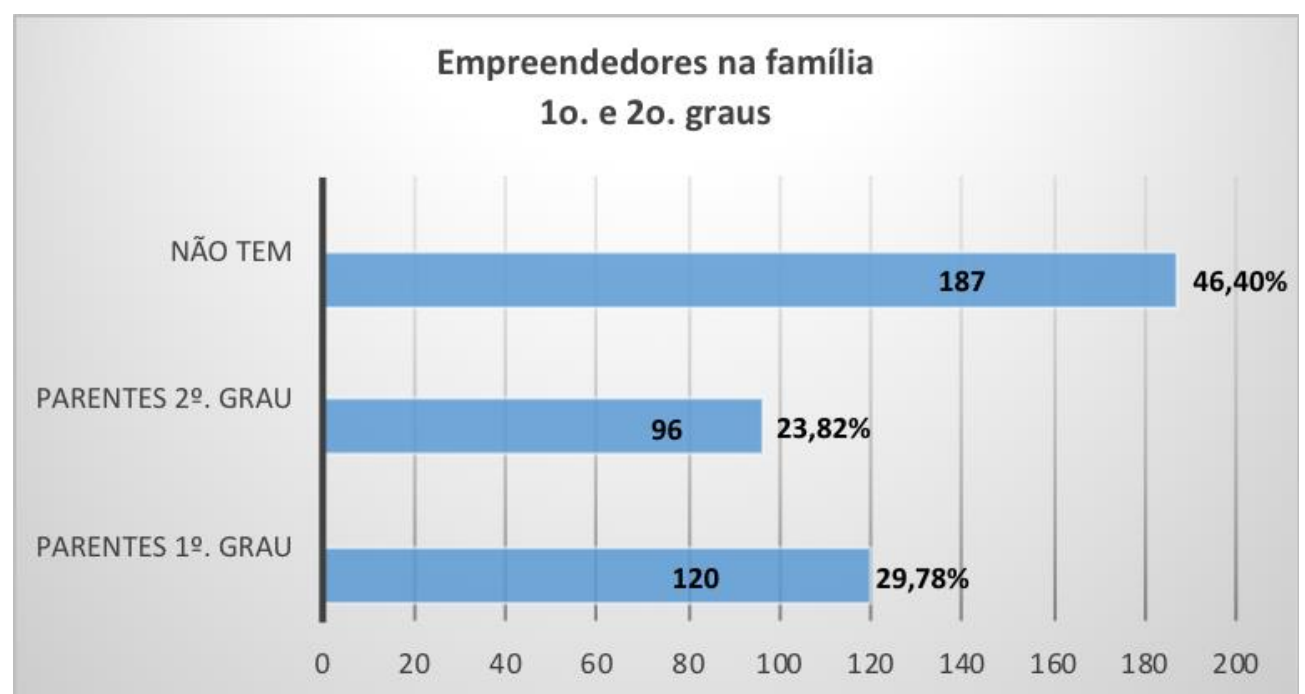

Gráfico 15: Porcentual de alunos em relação à empreendedores na família - 1‥ e 2‥ Graus Fonte: autora

Outro questionamento feito pelo instrumento foi relacionado ao conhecimento dos participantes quanto ao mercado de trabalho que entrariam após a conclusão do curso. Assim, quando perguntado se tinham conhecimento do mercado de trabalho em que iriam atuar, 135 participantes responderam que "não", o que equivale a 33,50\% do total de respondentes, e 268 participantes responderam que "sim", o que equivale a 66,50\% do total de respondentes, como ilustra a figura a seguir:

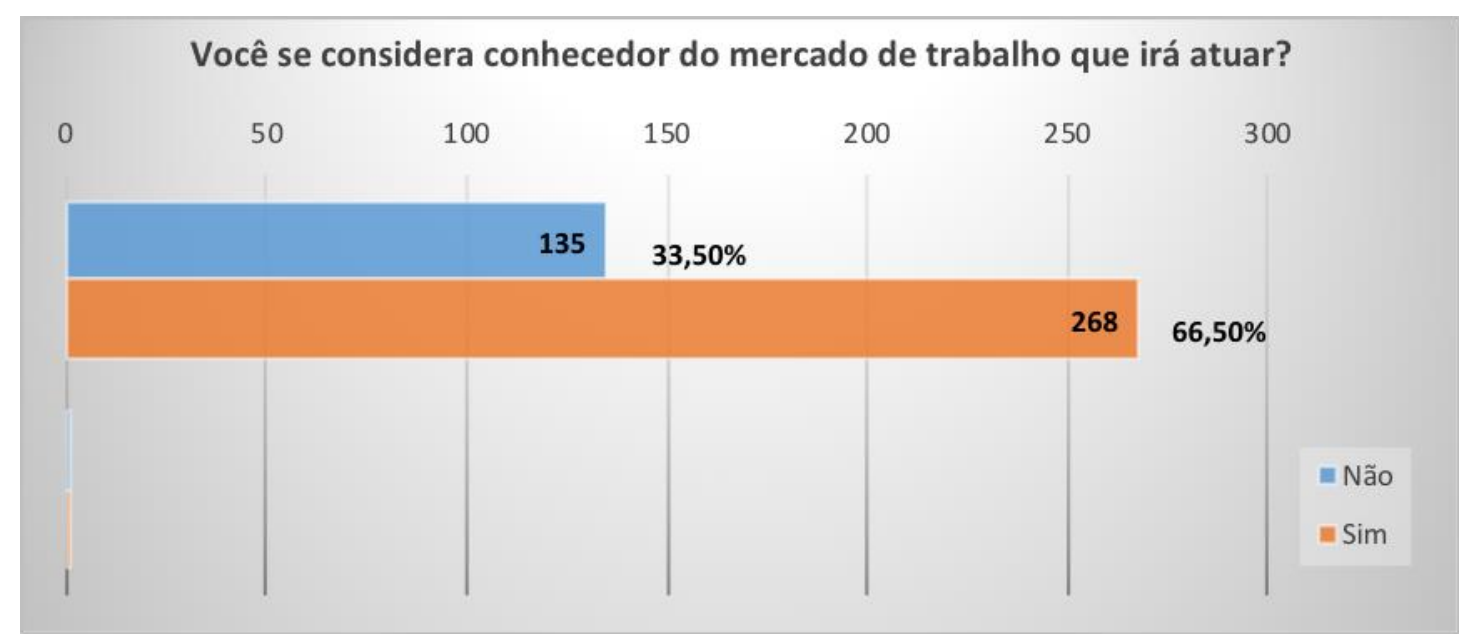

Gráfico 16: Porcentual de alunos em relação conhecimento de mercado que iriam atuar Fonte: autora

$\mathrm{Na}$ intenção de compreender este aspecto de conhecimento de mercado entre ingressantes e concluintes, foi feita a separação como mostra o gráfico a seguir: 


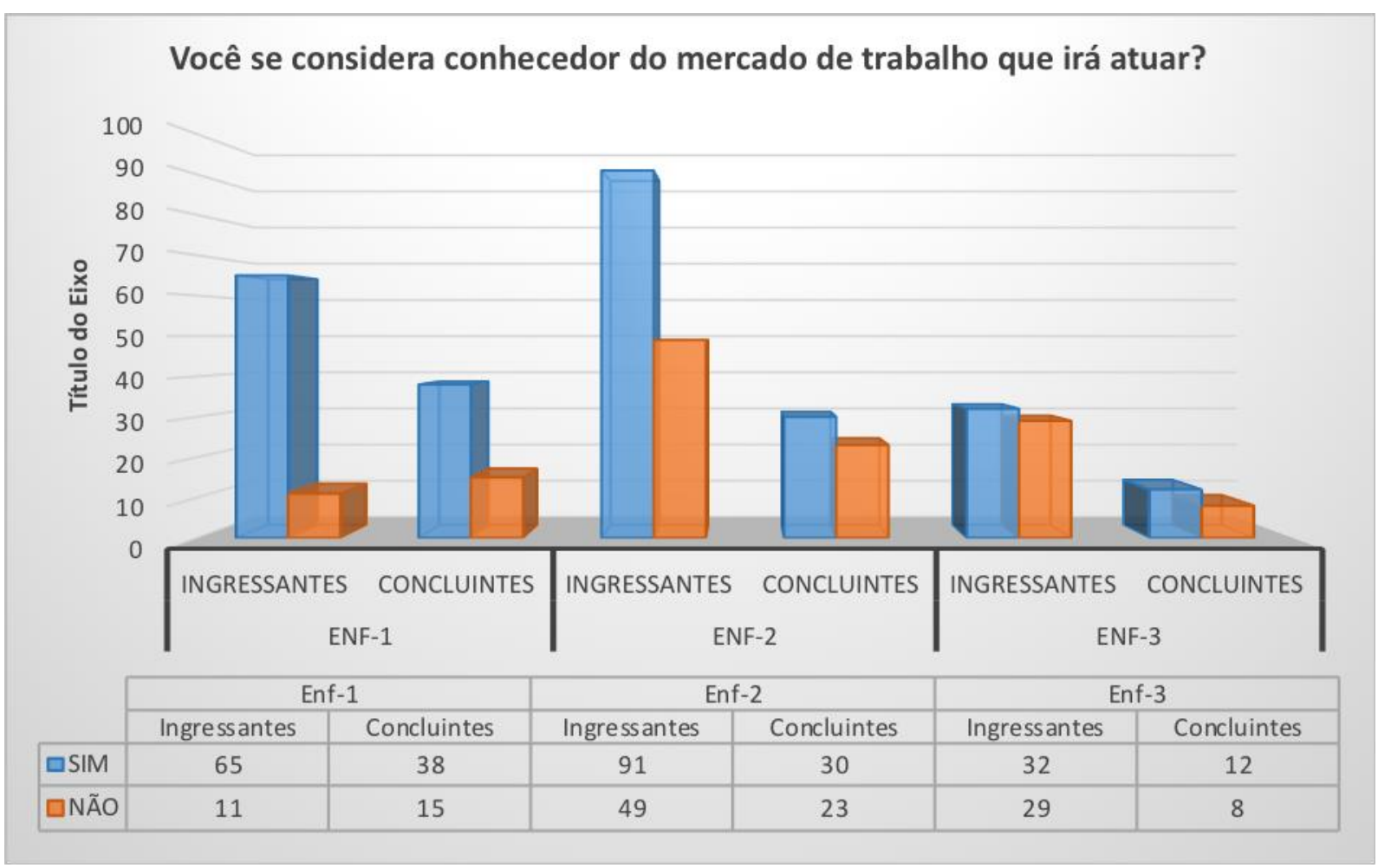

Gráfico 17: Porcentual de alunos em relação conhecimento de mercado que iriam atuar Fonte: autora

O que se pode aferir é que respostas "sim" tiveram maior incidência em alunos ingressantes, mas acentuadamente nos cursos Enf-1 e Enf-2, sendo que Enf-3 teve mais homogeneidade entre ingressantes e concluintes. Já respostas "não" teve menor incidência nos cursos Enf-1 e Enf-2, e de forma mais equiparada no curso Enf-3.

Esperava-se que os alunos concluintes tivessem resultados mais favoráveis que os ingressantes, tendo em vista que, de modo geral, cursos de graduação tem como um dos objetivos, formar o aluno para ser capaz de desempenhar sua profissão com excelência. As diretrizes curriculares, orientam as instituições de ensino superior a formar profissionais capazes de desempenhar com afinco, as atividades que demandam sua profissão. Dito isso, podemos inferir que, a conclusão de um curso superior cumpre com este papel de possibilitar a aquisição de expertises, formando profissionais capacitados para um determinado mercado de trabalho. Conclui-se que, em tese, alunos concluintes há de terem esta percepção num grau maior que alunos ingressantes, tendo em vista estarem mais bem preparados para os desafios da profissão. 
Este resultado pode servir de motivação para novas pesquisas que aprofundem o fato de os ingressantes terem esse tipo de resposta. Por exemplo, investigar se os alunos ingressantes de curso superior de enfermagem já exercem a profissão como auxiliar de enfermagem ou mesmo técnico de enfermagem, níveis inferiores da profissão e que possuem qualificações próprias em instituições de nível técnico. Pode-se interpretar que esses alunos já trabalham no segmento da saúde e por isso já possuem certo grau de conhecimento e isso atribui-Ihes alguma maturidade.

Perguntas deste tipo podem ser inseridas numa pesquisa para aprofundar o conhecimento sobre esse assunto como: já trabalha ou trabalhou na profissão? Tem algum parente que trabalha na área da saúde? Ou até mesmo "explique sua resposta" no caso de os participantes responder que conhece o mercado de trabalho em que irá atuar. São formas de investigar o comportamento dos respondentes e analisar o porquê deste conhecimento. A riqueza de uma pesquisa científica não reside nos resultados que dela vem, mas sim das possibilidades que surgem desses resultados em buscar novas respostas em novas pesquisas, tornando cíclico o processo de busca do conhecimento.

\subsubsection{Análise dos Dados perdidos para as questões específicas das CCE's}

Hair et.al (2009) recomendam iniciar pesquisas quantitativas que envolvem questionários como instrumento, por meio da análise dos dados perdidos ou missing data. Os dados perdidos podem ser originários da recusa ou esquecimento de um respondente, ou estarem relacionados à fase de digitação dos dados. Os dados perdidos quando em grande quantidade podem enviesar os resultados de uma pesquisa. A análise de frequências dos dados perdidos ocorreu para identificar a extensão de ocorrência em toda a amostra, para as variáveis selecionadas. Foram analisados os 403 instrumentos, e o resultado é apresentado no quadro a seguir: 


\begin{tabular}{|c|c|c|c|c|c|c|c|c|c|c|c|}
\hline \multicolumn{12}{|c|}{ CCE's ${ }^{\mathrm{a}}$} \\
\hline \multirow{2}{*}{$\mathbf{Q}$} & \multicolumn{2}{|c|}{ Ausente } & \multirow{2}{*}{ Q } & \multicolumn{2}{|c|}{ Ausente } & \multirow[b]{2}{*}{ Q } & \multicolumn{2}{|c|}{ Ausente } & \multirow{2}{*}{ Q } & \multicolumn{2}{|c|}{ Ausente } \\
\hline & Contagem & $\%$ & & Contagem & $\%$ & & Contagem & $\%$ & & Contagem & $\%$ \\
\hline $\mathrm{Q1}^{\mathrm{a}}$ & 0 & 0,0 & Q15 & 0 & 0,0 & Q29 & 0 & 0,0 & Q43 & 0 & 0,0 \\
\hline $\mathrm{Q} 2$ & 0 & 0,0 & Q16 & 0 & 0,0 & Q30 & 0 & 0,0 & Q44 & 0 & 0,0 \\
\hline Q3 & 0 & 0,0 & Q17 & 0 & 0,0 & Q31 & 0 & 0,0 & Q45 & 0 & 0,0 \\
\hline Q4 & 0 & 0,0 & Q18 & 0 & 0,0 & Q32 & 0 & 0,0 & Q46 & 0 & 0,0 \\
\hline Q5 & 0 & 0,0 & Q19 & 0 & 0,0 & Q33 & 0 & 0,0 & Q47 & 0 & 0,0 \\
\hline Q6 & 0 & 0,0 & $\mathrm{Q} 20$ & 0 & 0,0 & Q34 & 0 & 0,0 & Q48 & 0 & 0,0 \\
\hline Q7 & 0 & 0,0 & Q21 & 0 & 0,0 & $\mathrm{Q} 35$ & 0 & 0,0 & Q49 & 0 & 0,0 \\
\hline Q8 & 0 & 0,0 & Q22 & 0 & 0,0 & Q36 & 0 & 0,0 & Q50 & 0 & 0,0 \\
\hline Q9 & 0 & 0,0 & Q23 & 0 & 0,0 & Q37 & 0 & 0,0 & Q51 & 0 & 0,0 \\
\hline$\overline{\mathrm{Q} 10}$ & 0 & 0,0 & Q24 & 0 & 0,0 & Q38 & 0 & 0,0 & Q52 & 0 & 0,0 \\
\hline Q11 & 0 & 0,0 & Q25 & 0 & 0,0 & Q39 & 0 & 0,0 & Q53 & 0 & 0,0 \\
\hline $\mathrm{Q12}$ & 0 & 0,0 & Q26 & 0 & 0,0 & $\mathrm{Q} 40$ & 0 & 0,0 & $\mathrm{Q} 54$ & 0 & 0,0 \\
\hline Q13 & 0 & 0,0 & Q27 & 0 & 0,0 & Q41 & 0 & 0,0 & Q55 & 0 & 0,0 \\
\hline$\overline{\mathrm{Q} 14}$ & 0 & 0,0 & Q28 & 0 & 0,0 & Q42 & 0 & 0,0 & & & \\
\hline
\end{tabular}

Quadro 29: Análise de frequência dos dados perdidos Fonte: Autora

Nota-se que a etapa de análise de dados faltantes resultou em nula, ou seja, nenhuma resposta do instrumento de pesquisa aplicado ficou sem resposta, o que validou $100 \%$ dos instrumentos de pesquisa. Como a pesquisa continha como restrição a maioridade de idade dos alunos, o corte foi feito já no momento de abordagem, quando da leitura do termo de consentimento que trazia a restrição em seu texto.

\subsubsection{Método de Análise de Distribuição dos Dados}

A análise a seguir, denominada distribuição de dados, distribuição de frequências ou histograma, trata de representação gráfica em colunas ou em barras verticais de um conjunto de dados previamente tabulado, dividido em classes e tem caráter preliminar em qualquer estudo, sendo um importante indicador da distribuição de dados e de sua validade (MORETTIN E BUSSAB, 2010).

A altura de cada retângulo representa a quantidade ou a frequência absoluta com que o valor da classe ocorre no conjunto de dados para classes uniformes ou a densidade de frequência para classes não uniformes. Quando o volume de dados aumenta indefinidamente dentro do conjunto de dados e o intervalo de classes tende a zero (o que torna os retângulos cada vez mais finos e altos), a distribuição de frequência torna-se uma distribuição de densidade de probabilidades (MORETTIN E BUSSAB, 2010). A base de cada retângulo representa uma classe, distribuída numa escala de análise, neste caso, a pontuação de 5 a 25 que correspondem a escala do instrumento. 
Histogramas com distribuição aproximadamente normal possuem como característica principal o formato de um sino que tende a ser simétrico. Entretanto, os histogramas podem assumir formas variadas de acordo com a distribuição de probabilidade dos dados. Em termos matemáticos, segundo Battisti e Battisti (2008), um histograma é uma função $m_{i}$ que conta o número de observações de cada um dos intervalos de classe.

As características basilares de um histograma compreendem as formas com que são formados em que cada barra representa a frequência do intervalo respectivo de dados, os intervalos devem ter a mesma amplitude em largura e as barras devem estar todas juntas, não podendo ter separações em blocos. O formato de um sino representa a simetria e isso significa que a medida dos dados está no centro do desenho formado, as frequências mais altas estão no centro o que representa o padrão que requer o modelo de análise.

Gráficos de histogramas com assimetria são aqueles que apresentam variações no padrão estabelecido e podem surgir de forma negativa ou positiva. Histograma com assimetria positiva ocorre quando a média dos dados está localizada a esquerda do centro e a cauda a direita é alongada, o que significa que o limite inferior é controlado ou quando não podem ocorrer valores abaixo de determinado limite. Já assimetria negativa ocorre quando os dados estão localizados mais à direita do desenho, o que alonga a cauda à esquerda o que significa que o limite superior é controlado ou quando não podem ocorrer valores acima de certo limite (MORETTIN e BUSSAB, 2010). 
A figura a seguir traz o histograma da análise das distribuições:

Observa-se de modo geral, que os gráficos apresentam um certo padrão - formato de sino, que caracteriza-se por apresentar o valor máximo no ponto central e os pontos equidistantes desse ponto terem a mesma frequência, com pouca ou nenhuma variação extrema (caldas a direita ou a esquerda). As características mais evidentes em termos de padrão são "Persistência", "Correr riscos calculados", "Planejamento e monitoramento sistemático", "Persuasão e redes de contato" e "Independência e autoconfiança", sinalizados em azul e considerando a escala de 5 a 25 de que trata o instrumento, podendo-se aferir que tais características trazem, além do padrão estabelecido, uma pontuação acima da média de 15, ficando em patamares entre 15 a 20 pontos, o que segundo McClelland (1987), são possuidores das características empreendedoras, sendo portanto um resultado favorável na pesquisa, apesar do nível baixo.
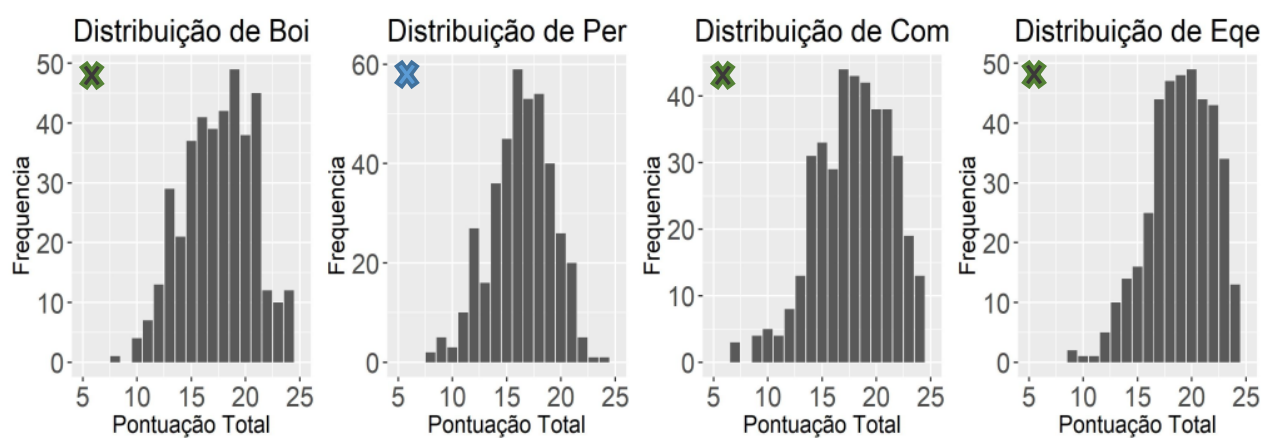

Distribuição de Crc

Distribuição de Em
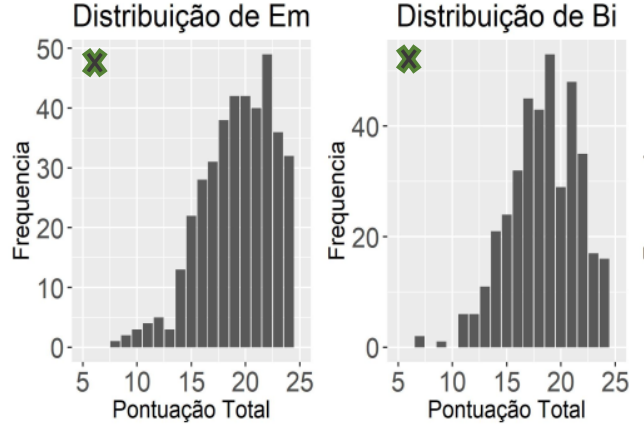

Distribuição de Pms
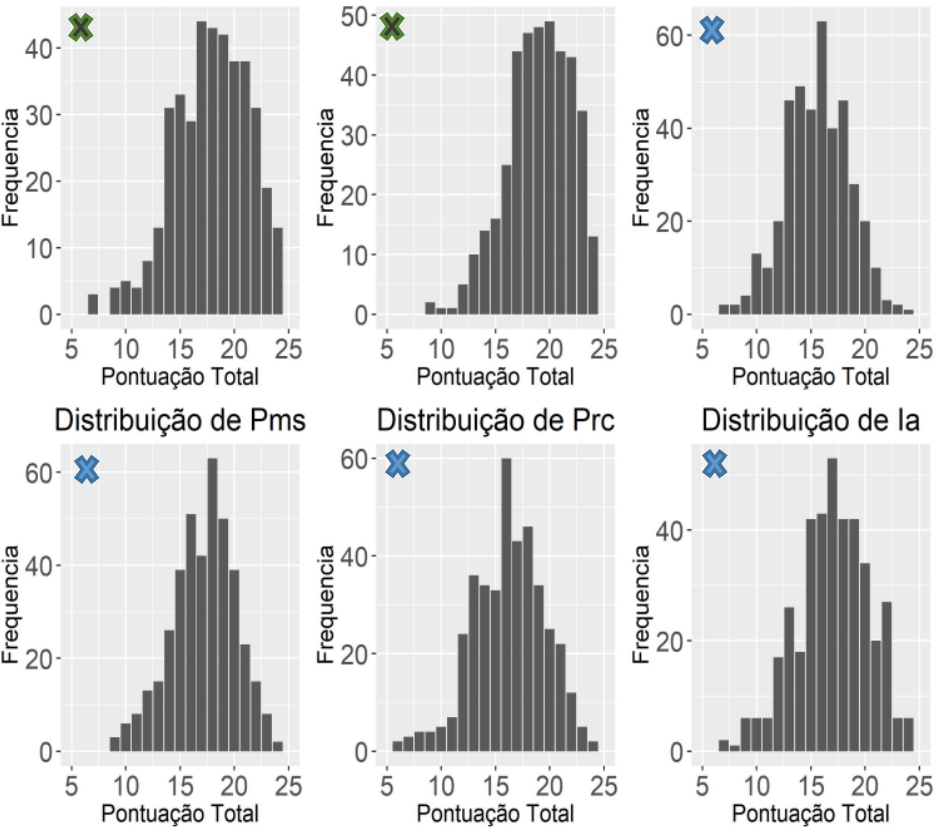

Distribuição de la
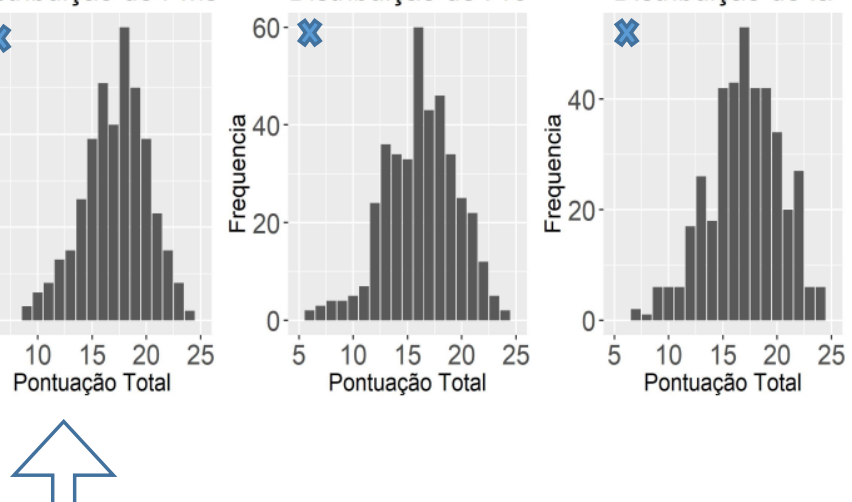

Duas características CCE's são apresentadas com uma certa assimetria, sinalizadas em preto, "Busca de oportunidades e iniciativa", "Exigência de qualidade e eficiência", "Comprometimento" e "Estabelecimento de metas", com caldas a esquerda, o que demonstra assimetria negativa. Para Battisti e Battisti (2008), imagens com assimetria negativa ocorre quando a média dos dados está localizada à direita do centro da figura e a cauda à esquerda é alongada. Esta forma ocorre quando o limite superior é controlado ou quando não podem ocorrer valores acima de certo limite. Apesar disso, no entanto, as variações identificadas nas análises não são consideradas discrepantes por serem consideradas ainda dentro dos limites padrões que as análises de histogramas recomendam.

Ilustração 1: Gráficos de Distribuição das CCE's global com análises

Fonte: Autora 
Os gráficos de distribuição desta pesquisa apresentados acima atendem aos quesitos de normalidade que, segundo Morettin e Bussab (2010), devem possuir formas simétricas que normalmente são representadas pelo formato de sino. No caso desta pesquisa, as imagens podem ser consideradas no formato de sinos, diferenciando-se em termos insignificantes em relação à longevidade de caldas tanto a direita quanto a esquerda, dando a normalidade que o procedimento estatístico requer.

\subsubsection{Análise Descritiva das CCE's características comportamentais empreendedoras}

Para a pesquisa quantitativa, como já mencionado, foi utilizado um instrumento devidamente validado em trabalhos científicos anteriores, bem como utilizado pelo SEBRAE nos eventos EMPRETEC que trabalha o desenvolvimento das competências empreendedoras (MOTA, 2013, TORRES, 2015, KRÜGER, 2019, FERNANDES, 2014, PIETROVSKI, 2019; FONSECA e MUYLDER, 2010; MARION-SANTOS e PAIXÃO, 2013; SEBRAE, 2017; LEAL, 2009). Tal instrumento, desenvolvido por David McClelland (1987) como já citado, refere-se às características comportamentais empreendedoras (CCE's) com o objetivo de identificar por meio dessas características, o perfil empreendedor dos participantes da pesquisa. $\mathrm{O}$ questionário, tipo estruturado, é composto por 55 questões assertivas, com escala do tipo Likert com gradação: 1 = Discordo plenamente; 2 = Discordo parcialmente; 3 = Não sei opinar; 4 = Concordo parcialmente; 5 = Concordo totalmente, de acordo com sua percepção, diante de cada uma das 55 assertivas que compõem o instrumento, distribuído da seguinte forma:

\begin{tabular}{|c|c|c|c|c|c|c|}
\hline CCE & \multicolumn{7}{|c|}{ QUESTÕES } \\
\hline Busca de oportunidades e iniciativa & Q1 & Q12 & Q23 & Q34* & Q45 & FC \\
\hline Persistência & Q2 & Q13 & Q24 & Q35* & Q46 & FC \\
\hline Comprometimento & Q3 & Q14 & Q25 & Q36 & Q47* & FC \\
\hline Exigência de qualidade e eficiência & Q4 & Q15 & Q26 & Q37 & Q48 & - \\
\hline Correr riscos calculados & Q5 & Q16 & Q27 & Q38* & Q49 & FC \\
\hline Estabelecimento de metas & Q6 & Q17* & Q28 & Q39 & Q50 & FC \\
\hline Busca de informações & Q7 & Q18 & Q29* & Q40 & Q51 & FC \\
\hline Planejamento e monitoramento sistemáticos & Q8 & Q19 & Q30 & Q41* & Q52 & FC \\
\hline Persuasão e redes de contato & Q9 & Q20* & Q31 & Q42 & Q53 & FC \\
\hline Independência e autoconfiança & Q10 & Q21* & Q32 & Q43 & Q54 & FC \\
\hline
\end{tabular}

Quadro 30: Distribuição das questões por dimensão $\rightarrow$ * Questões Negativas Fonte: McClelland (1987) 
Os $\left({ }^{*}\right)$ do quadro acima correspondem às questões negativas em que a pontuação deve ser subtraída do resultado final da respectiva característica e deve-se acrescentar 6 (seis) pontos ao final do somatório. As questões de número 11, 22, 33, 44 e 55 correspondem ao "Fator de Correção", utilizado para evitar que, muitas vezes de modo inconsciente, o respondente apresente uma autoimagem excessivamente favorável. O Fator de Correção é utilizado se o somatório da pontuação dessas questões for igual ou superior a 20 (vinte) pontos. Se isso ocorrer, todas as CCE's devem ser corrigidas com a subtração dos pontos correspondentes (MCCLELLAND, 1987; KRÜGER, 2016).

O instrumento de CCE's prevê um fator de correção aplicado aos questionários em que os respondentes apresentarem uma supervalorização das características, aplicando-se os respectivos cálculos:

\begin{tabular}{|c|c|}
\hline \multicolumn{2}{|c|}{ FATOR DE CORREÇÃO } \\
\hline Se a pontuação do Fator de Correção for... & $\begin{array}{c}\text {... subtraia o número de correção da pontuação } \\
\text { total de cada competência }\end{array}$ \\
\hline 24 ou 25 & 7 \\
\hline 22 ou 23 & 5 \\
\hline 20 ou 21 & 3 \\
\hline 19 ou menos & 0 \\
\hline
\end{tabular}

Quadro 31: Fator de correção das CCE's

Fonte: Mansfield et al. (1987).

É importante conhecer os casos que necessitaram da aplicação do fator de correção, com o propósito de visualizar a ocorrência desta valorização das características. O quadro a seguir ilustra os totais e percentuais de questionários que necessitaram do fator de correção:

\begin{tabular}{|c|c|c|}
\hline Fator de correção & $\mathbf{n}$ & Percentual \\
\hline 0 & 289 & $71,71 \%$ \\
\hline 3 & 80 & $19,85 \%$ \\
\hline 5 & 21 & $5,21 \%$ \\
\hline 7 & 13 & $3,23 \%$ \\
\hline & 403 & $100,00 \%$ \\
\hline
\end{tabular}

Quadro 32: Fator de correção das CCE's aplicado a pesquisa

Fonte: Adaptado de Mansfield et al. (1987).

Observa-se que cerca de $70 \%$ dos participantes tiveram pontuações menores que 19 , aproximadamente $20 \%$ tiveram pontuações entre 20 ou 21 e os demais, cerca de $8,44 \%$ tiveram pontuações entre 23 a 25, as quais necessitaram aplicar fator de correção. Com isso pode-se aferir que na grande maioria, não foi preciso aplicar o fator de correção. 
A pontuação máxima é de 25 (vinte e cinco) pontos para cada uma das dimensões. Quando o total for inferior a 15 pontos, o indivíduo não possui a respectiva característica, ou seja, inexistente. Se a pontuação for entre 15,00 e 17,50 o indivíduo possui um perfil empreendedor de nível baixo, se a pontuação for entre 17,51 e 20,00, o indivíduo possui perfil empreendedor satisfatório e acima de 20, 00 possui perfil empreendedor de nível alto. A análise resulta em captar os resultados de todas as características, sendo considerado empreendedor quando possuir as dez características, indicadas na proposta das CCE's (MCCLELLAND, 1987, apud KRUGER, 2019).

A análise dos resultados iniciou com o cálculo dos mínimos, máximos, médias, desvio padrão e variância de cada característica e dimensão das CCE's estudadas. O quadro a seguir apresenta a estatística descritiva dos instrumentos respondidos pelos participantes:

\begin{tabular}{|l|c|c|c|c|c|c|}
\hline \multicolumn{1}{|c|}{ Características / Dimensões } & $\mathbf{n}$ & Média & $\begin{array}{c}\text { Desvio } \\
\text { Padrão }\end{array}$ & Mediana & min & max \\
\hline Busca de oportunidades e iniciativa & 403 & 17,46 & 3,35 & 18 & 5 & 25 \\
\hline Persistência & 403 & 16,34 & 2,86 & 16 & 8 & 24 \\
\hline Comprometimento & 403 & 17,97 & 3,52 & 18 & 7 & 25 \\
\hline Exigência de qualidade e eficiência & 403 & 19,08 & 3,05 & 19 & 9 & 25 \\
\hline Correr riscos calculados & 403 & 15,59 & 2,92 & 16 & 7 & 24 \\
\hline Estabelecimento de metas & 403 & 19,41 & 3,40 & 20 & 8 & 25 \\
\hline Busca de informações & 403 & 18,61 & 3,36 & 19 & 7 & 25 \\
\hline Planejamento e monitoramento sistemáticos & 403 & 17,16 & 2,96 & 17 & 9 & 24 \\
\hline Persuasão e redes de contato & 403 & 16,17 & 3,43 & 16 & 5 & 24 \\
\hline Independência e autoconfiança & 403 & 17,00 & 3,55 & 17 & 5 & 25 \\
\hline
\end{tabular}

Quadro 33: Análise Descritiva das CCE's

Fonte: Autora

A partir do quadro de análise descritiva é possível identificar as pontuações mínimas e máximas de cada dimensão das CCE's, assim como médias, desvio padrão e mediana. É possível identificar pela média, que as características "Exigência de qualidade e eficiência", que obteve a média 19,08 e, "Estabelecimento de metas", que obteve a maior média de 19,41 , foram as mais bem pontuadas, o que demonstra que os alunos, de modo geral possuem tais características de maneira mais presente, ou em outras palavras, têm mais domínio desses fatores. A dimensão/característica "busca de informações" também aparece bem pontuada sendo a única na casa dos 18 pontos. 
Para Pietrovski et.al (2019), ambas características (EQE - exigência de qualidade e eficiência e, Em - estabelecimento de metas) podem estar relacionadas com certos aspectos do nosso cotidiano atual, tendo em vista as mudanças no comportamento das pessoas enquanto consumidoras e que esta postura de busca de maior qualidade é levada para o âmbito profissional. A sociedade moderna está muito mais exigente em termos de qualidade do que em épocas passadas, conscientes dos seus direitos, mais informados em relação ao que se pode exigir como consumidor, buscando produtos e serviços que atendam aos critérios que elegemos como importantes para nossas vidas. O Código de Defesa do Consumidor, documento público que traz aspectos legais de direitos e deveres de um comprador, é um material que por lei deve ser exposto nos estabelecimentos comerciais para consulta de qualquer consumidor. Tais fenômenos, parecem simples, mas resultam num empoderamento do consumidor, que por sua vez, muda seu comportamento de compra o que reflete na conduta dos estabelecimentos frente a este novo perfil de cliente. Este mesmo cliente, consciente de seus direitos e deveres, torna-se um cidadão mais exigente e sua busca por qualidade torna-se parte de seu comportamento social, refletindo em sua postura profissional. Cita-se, também, como fator preponderante a própria internet que disponibiliza em fração de segundos, dezenas de páginas filtradas com base na pesquisa feita por internautas, o que facilita o compartilhamento e a socialização de informações.

Para Mota (2014), características que envolvem estabelecimento de metas podem estar relacionadas também com comportamentos sociais atuais, tendo em vista que o termo "meta" passou a ser utilizado de forma mais frequente tanto no mundo do trabalho quanto no pessoal, o que pode ter trazido certa popularidade ao termo, sendo atrelado não só a questões profissionais, mas por estar relacionado com objetivos de vida.

O mesmo pode ser interpretado pela característica "busca de informações", que teve pontuação de 18.61 e que também pode estar relacionada com aspectos sociais do próprio desenvolvimento humano com nossa realidade, aliado ao fato de termos nos dias de hoje, uma quantidade infinitamente maior de informações disponíveis que no passado, o que faz com que as pessoas, os sujeitos, mudem sua percepção de mundo e seu papel na sociedade moderna. 
Ainda com relação aos dados obtidos nos cálculos de média tem-se a característica "correr riscos calculados" com 15,59 de média, sendo o menor número aferido, estando muito próximo do fator 15 que para McClelland (1987), é considerado como inexistente. Krüger (2016) argumenta que esta característica "correr riscos calculados" é o fator comportamental menos presente em pesquisas sobre comportamento empreendedor e associa isso ao fato do temor das pessoas em perder o que investiu e este aspecto pode estar relacionado de modo muito especial a características econômicas e conjunturais de uma região, de um país, que por razões de instabilidade econômica, por exemplo, não encorajam seus profissionais a assumirem riscos financeiros por terem certa preocupação com o sucesso do empreendimento. Fernandes (2014) afirma que aspectos financeiros conjunturais tendem a influenciar fortemente as decisões de se investir num novo projeto empreendedor. Projetos assim envolvem investimentos de tempo, conhecimento, esforços e financeiros e, numa economia instável, os profissionais sentem-se menos respaldados em relação ao êxito nesses projetos.

No que diz respeito aos dados obtidos na coluna de valor mínimo, chama atenção as características "busca de oportunidades e iniciativa", "persuasão e rede de contato", e "Independência e autoconfiança" que tiveram 5, sendo a menor nota mínima. Isso significa que alguns participantes responderam o mínimo em todas as questões, o que pode levar a algumas conclusões, dentre elas, o fato de os alunos não terem se interessado em participar da pesquisa e não darem muita atenção ou não se comprometerem com a atividade de responder, ou mesmo que não entenderam a dinâmica da pesquisa, perderam a apresentação da pesquisadora, etc. Segundo Hair et.al (2009), tais eventos quando ocorrem de maneira acentuada, ou maior número, podem causar viés nos resultados da pesquisa. As análises de distribuição e dispersão de dados, apresentadas mais adiante, irão mostrar que o número de incidência desses valores foi insignificante, não sendo considerados responsáveis por comprometer as análises da presente pesquisa.

Com relação aos dados da coluna de desvio padrão, para Morettin e Bussab (2010), trata-se de uma medida que expressa o grau de dispersão de um conjunto de dados, ou seja, desvio padrão indica o quanto um conjunto de dados é uniforme e quanto mais próximos do conjunto de dados, mais homogêneo são os dados. Além de expressar a variabilidade da população, o desvio padrão comumente é usado para medir a confiança em cálculos 
estatísticos e geralmente permite sintetizar os resultados de uma análise. Para Morettin e Bussab (2010), os números do desvio padrão sempre são apresentados junto da média. Para os autores, um não faz sentido sem o outro. Sendo assim, quanto menor o desvio padrão, mais homogênea é a amostra da pesquisa. Um alto desvio padrão pode indicar que os pontos dos dados estão espalhados por uma ampla gama de valores e quando isso ocorre, novas análises são necessárias para se identificar possíveis discrepâncias e interpretá-las adequadamente. Quanto aos valores de desvio padrão desta pesquisa, pode-se aferir que houve uma singularidade nos números, o que significa que a variância manteve-se numa constante, entre 2,90 e 3,50, resultados considerados, estatisticamente válidos para o constructo da pesquisa, não tendo nenhum valor fora deste intervalo, que poderia representar algum tipo de dissociação.

Nos gráficos a seguir, verifica-se as médias das características empreendedoras dos três cursos separados, sendo o primeiro, com dados dos alunos ingressantes:

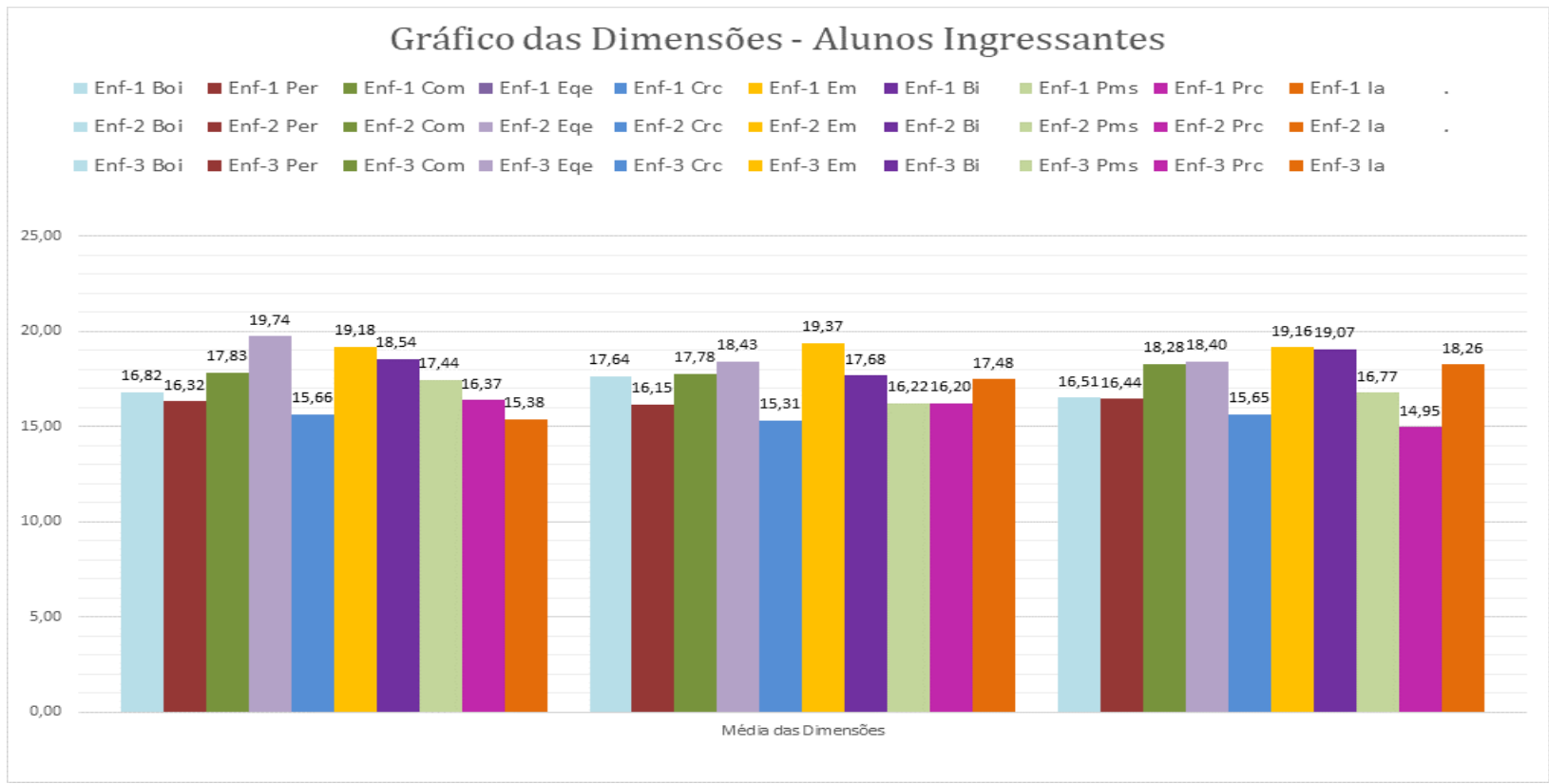

Gráfico 18: Análise Descritiva das CCE's por curso - alunos ingressantes Fonte: Autora

O gráfico acima ilustra os resultados obtidos por meio da pesquisa com os alunos ingressantes dos três cursos pesquisados, separados em blocos para possibilitar uma análise comparativa dos resultados entre os alunos, por característica empreendedora. Observa-se uma constante nos números, com algumas sutis exceções em "estabelecimento de metas" e "busca de informações" que tiveram uma média maior em todos os 3 cursos. 
E no gráfico a seguir, os dados dos alunos concluintes, separados por curso:

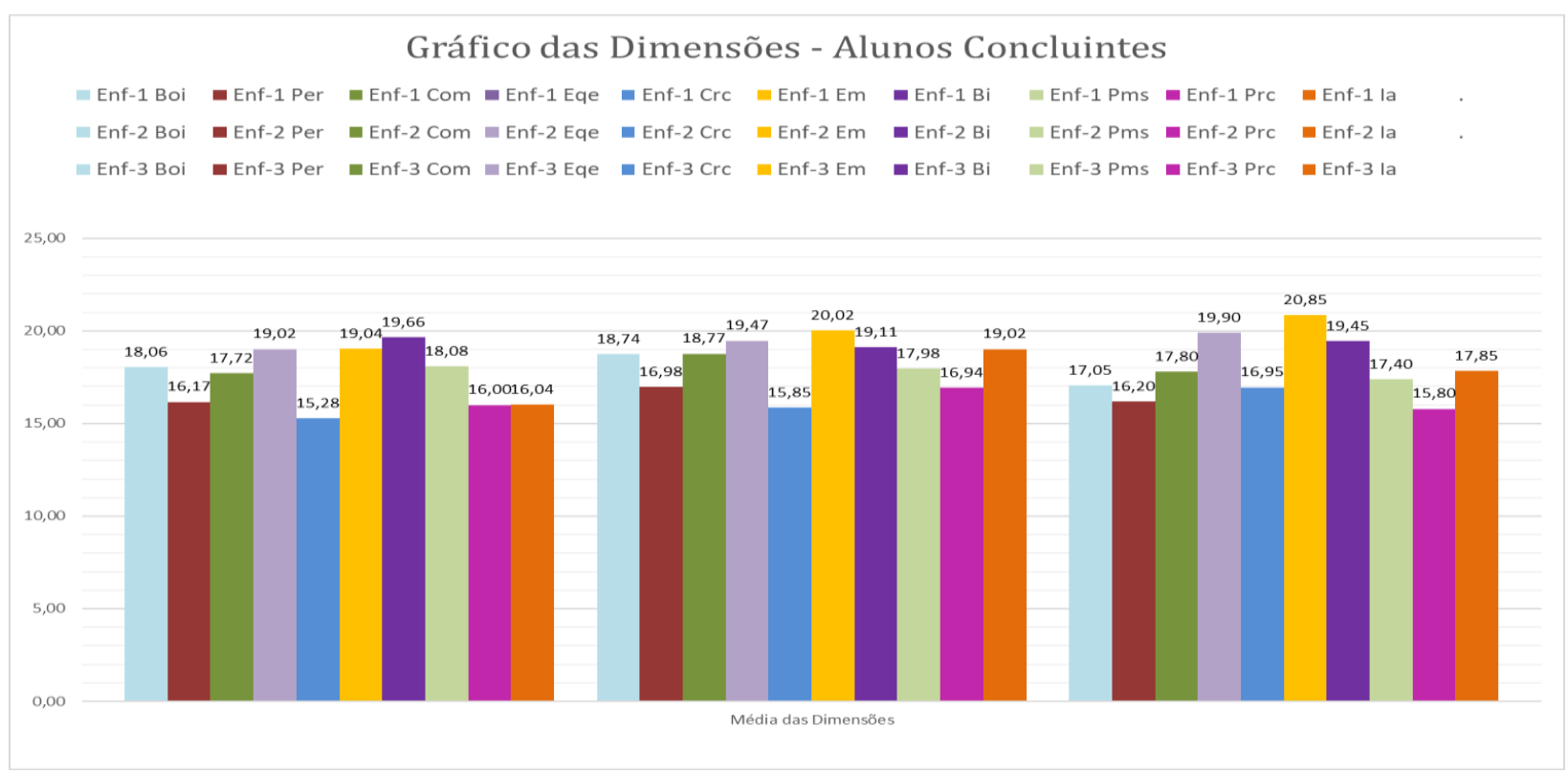

Gráfico 19: Análise Descritiva das CCE's por curso - alunos concluintes Fonte: Autora

O mesmo pode se dizer do gráfico que traz os dados dos alunos concluintes. Nota-se que as características "estabelecimento de metas" e "busca de informações" que tiveram uma média maior em todos os 3 cursos também nos concluintes, corroborando com o que as tabelas anteriores também apontavam.

Os gráficos a seguir trazem a média das características empreendedoras, ilustrando de forma separada os participantes ingressantes e concluintes: 


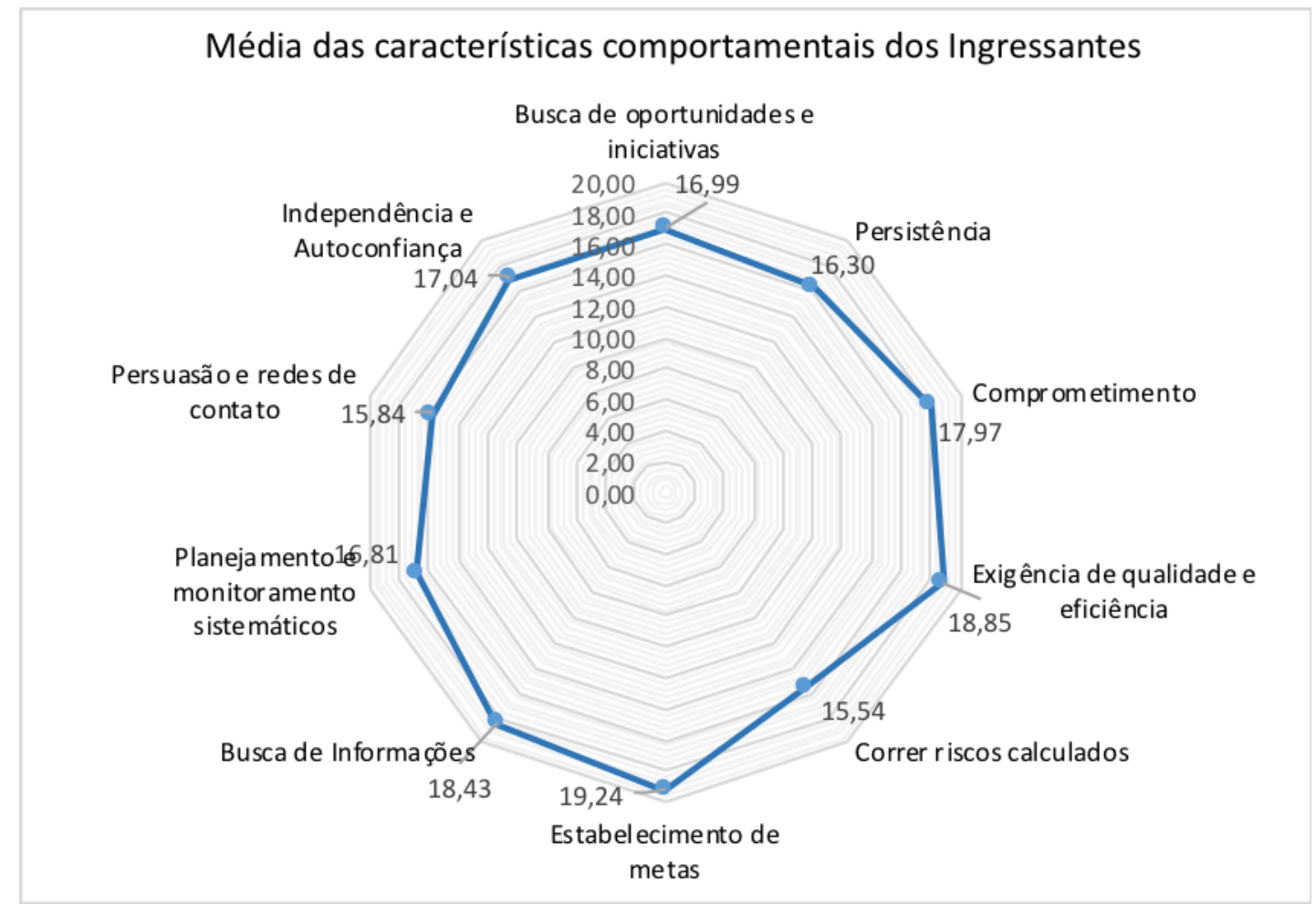

Gráfico 20: Média das CCE's dos ingressantes

Fonte: Autora

\section{Média das características comportamentais dos Concluintes}

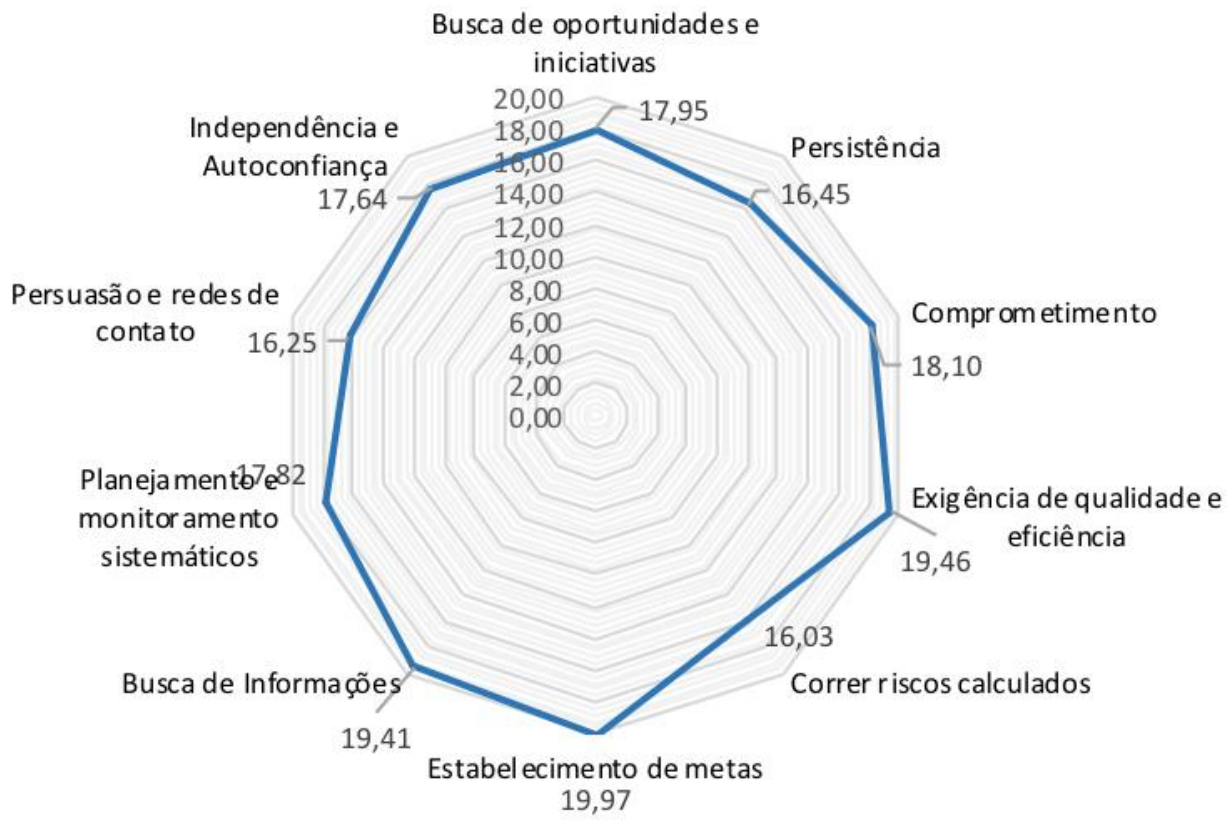

Gráfico 21: Média das CCE's dos concluintes Fonte: Autora 
O quadro e o gráfico a seguir é uma junção dos dois gráficos anteriores para demonstrar, em resultados sobrepostos, as diferenças entre os percentuais dos números, as características empreendedoras, comparando ingressantes e concluintes. Tiveram resultados melhores, ou seja, houve um avanço em termos de resultados, podendo-se concluir que o perfil empreendedor dos participantes concluintes teve um desempenho melhor. As características que em que se identifica um avanço nos resultados foram "Busca de oportunidades e iniciativas", avanço de cerca de 1 ponto, "Busca de Informações" também cerca de 1 ponto e "Planejamento e monitoramento sistemáticos", também com cerca de 1 ponto a mais nos resultados dos participantes concluintes comparando com ingressantes. Conclui-se que as melhoras nos perfis dos concluintes foi leve, não representando uma margem significativa.

Segundo McClelland (1987), em se tratando de resultados de pesquisa com o uso do instrumento das CCE's, quando o total for inferior a 15 pontos, o indivíduo não possui a respectiva característica, ou seja, inexistente. Se a pontuação for entre 15,00 e 17,50 o indivíduo possui um perfil empreendedor de nível baixo, se a pontuação for entre 17,51 e 20, 00, o indivíduo possui perfil empreendedor satisfatório e acima de 20, 00 possui perfil empreendedor de nível alto. A análise resulta em captar os resultados de todas as características, considerando empreendedor quando possuir as dez características, indicadas nas CCE's (MCCLELLAND, 1987). O quadro ilustra por cores esta escala sendo cinza de 15,00 e 17,50, laranja de 17,51 e 20 e verde acima de 20 pontos:

\begin{tabular}{|l|c|c|}
\hline \multicolumn{1}{|c|}{ CCE's } & Ingressantes & Concluintes \\
\hline Busca de oportunidades e iniciativas & 16,99 & 17,95 \\
\hline Persistência & 16,30 & 16,45 \\
\hline Comprometimento & 17,97 & 18,10 \\
\hline Exigência de qualidade e eficiência & 18,85 & 19,46 \\
\hline Correr riscos calculados & 15,54 & 16,03 \\
\hline Estabelecimento de metas & 19,24 & 19,97 \\
\hline Busca de Informações & 18,43 & 19,41 \\
\hline Planejamento e monitoramento sistemáticos & 16,81 & 17,82 \\
\hline Persuasão e redes de contato & 15,84 & 16,25 \\
\hline Independência e Autoconfiança & 17,04 & 17,64 \\
\hline
\end{tabular}

Quadro 34 : Comparativo das médias das CCE's entre ingressantes e concluintes Fonte: Autora 


\section{Comparativo da evolução do perfil empreendedor entre ingressantes e concluintes}

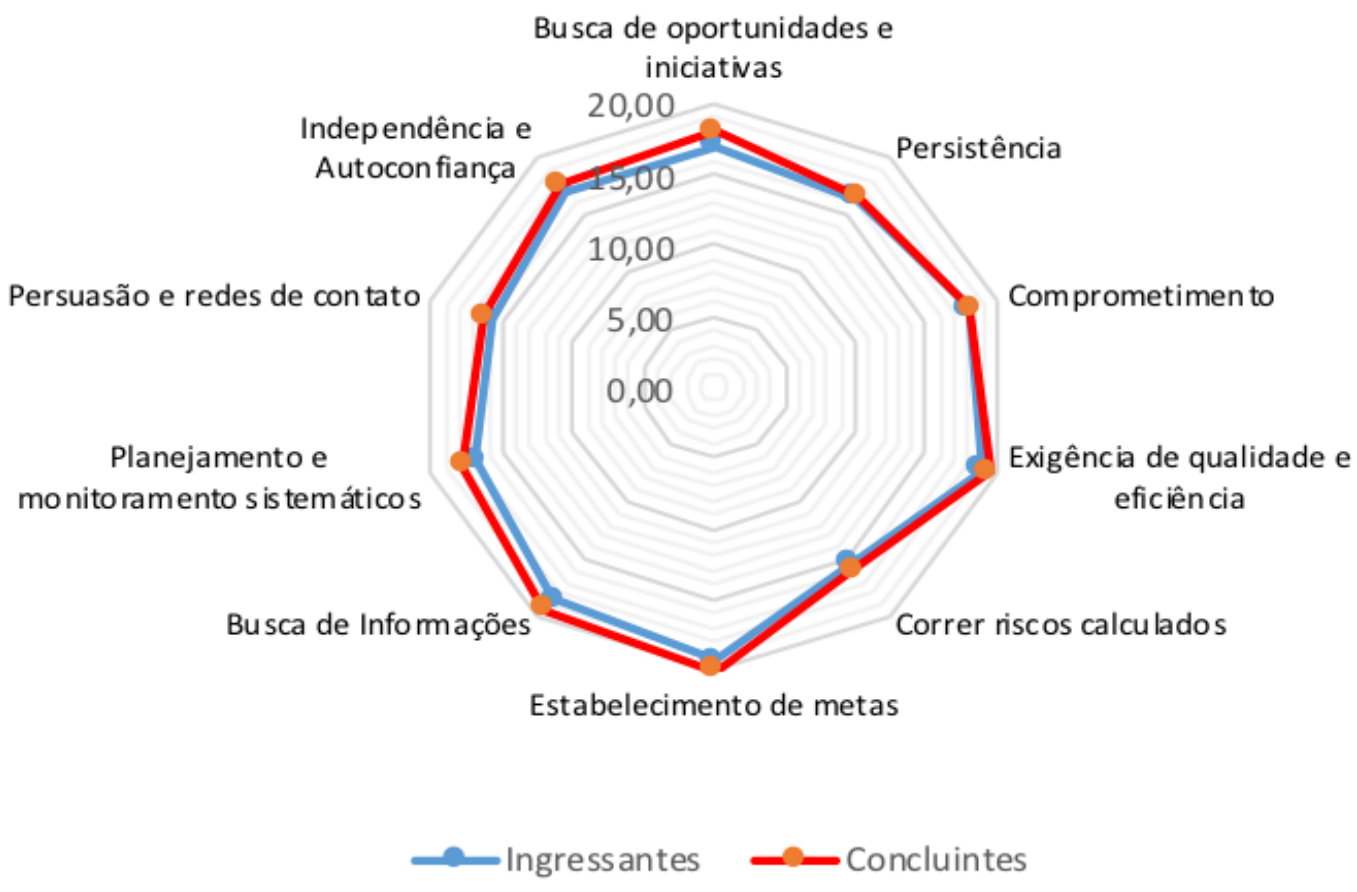

Gráfico 22: Gráfico comparativo das médias das CCE's entre ingressantes e concluintes Fonte: Autora

A seguir, são apresentados os resultados da análise por meio da ferramenta de boxplot para analisar a variabilidade dos dados. Foi aplicado o diagrama de boxplot considerando as variáveis ingressantes e concluintes para cada característica empreendedora. Segundo Morettin e Bussab (2010), o gráfico boxplot ou gráfico de caixa ou diagrama de extremos é um gráfico utilizado para avaliar a distribuição empírica dos dados.

Embora o Boxplot tenha como objetivo principal informações sobre localização e dispersão, também é de extrema importância a informação que fornece sobre a cauda da distribuição. A análise de boxplot aqui utilizada teve o objetivo de comparar os dois grupos, como já citado, os participantes ingressantes e concluintes dos cursos pesquisados. Observase pelos gráficos que duas caixas, chamada caixa de amplitude interquartílica, são colocadas lado a lado para comparar a variabilidade, a média, a mediana e possíveis outliers e representa a metade, $50 \%$ dos dados e ao separar os extremos mostra a distância entre o primeiro e o terceiro quartis. Outro ponto importante a ser visualizado nessas comparações 
são as diferenças entre os quartis $\left(Q_{3}-Q_{1}\right)$ que é uma medida da variabilidade dos dados (MORETTIN E BUSSAB, 2010).

O boxplot é formado pelo primeiro e terceiro quartil e pelo quadro central que determina a mediana. As hastes inferiores e superiores se estendem, respectivamente, do quartil inferior até o menor valor não inferior ao limite inferior e do quartil superior até o maior valor não superior ao limite superior. Segundo Florencio (2010), os limites são calculados estatisticamente, da seguinte forma:

Limite inferior: $\max \left\{\min (\right.$ dados $\left.) ; Q_{1}-1,5\left(Q_{3}-Q_{1}\right)\right\}$

Limite superior: $\min \left\{\max (\right.$ dados $\left.) ; Q_{3}+1,5\left(Q_{3}-Q_{1}\right)\right\}$

Os pontos fora destes limites são considerados valores discrepantes, chamados outliers, e são denotados por símbolos $(\bullet)$. Pontos desgarrados (Outliers) podem afetar de forma adversa as decisões a serem tomadas a partir da análise dos dados se forem em grande quantidade ou não forem devidamente analisados (FLORENCIO, 2010). 
O esquema a seguir traz os dados analisados individualmente:
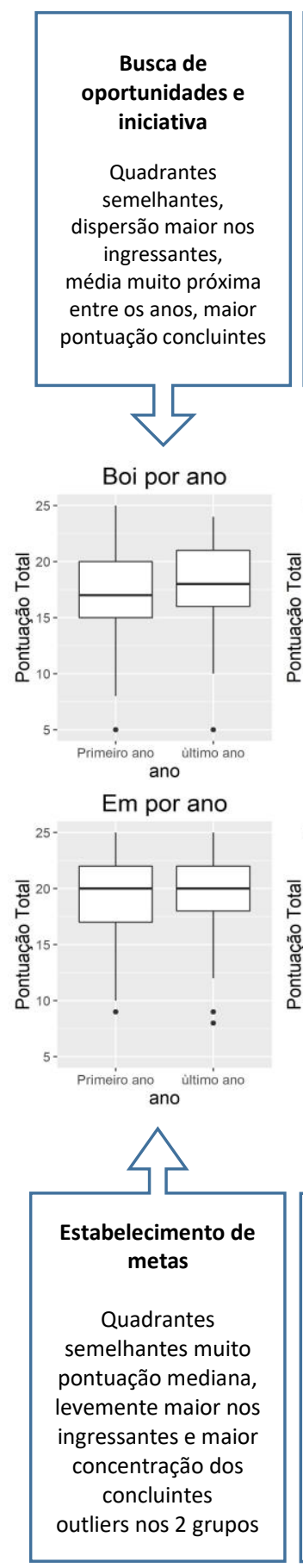
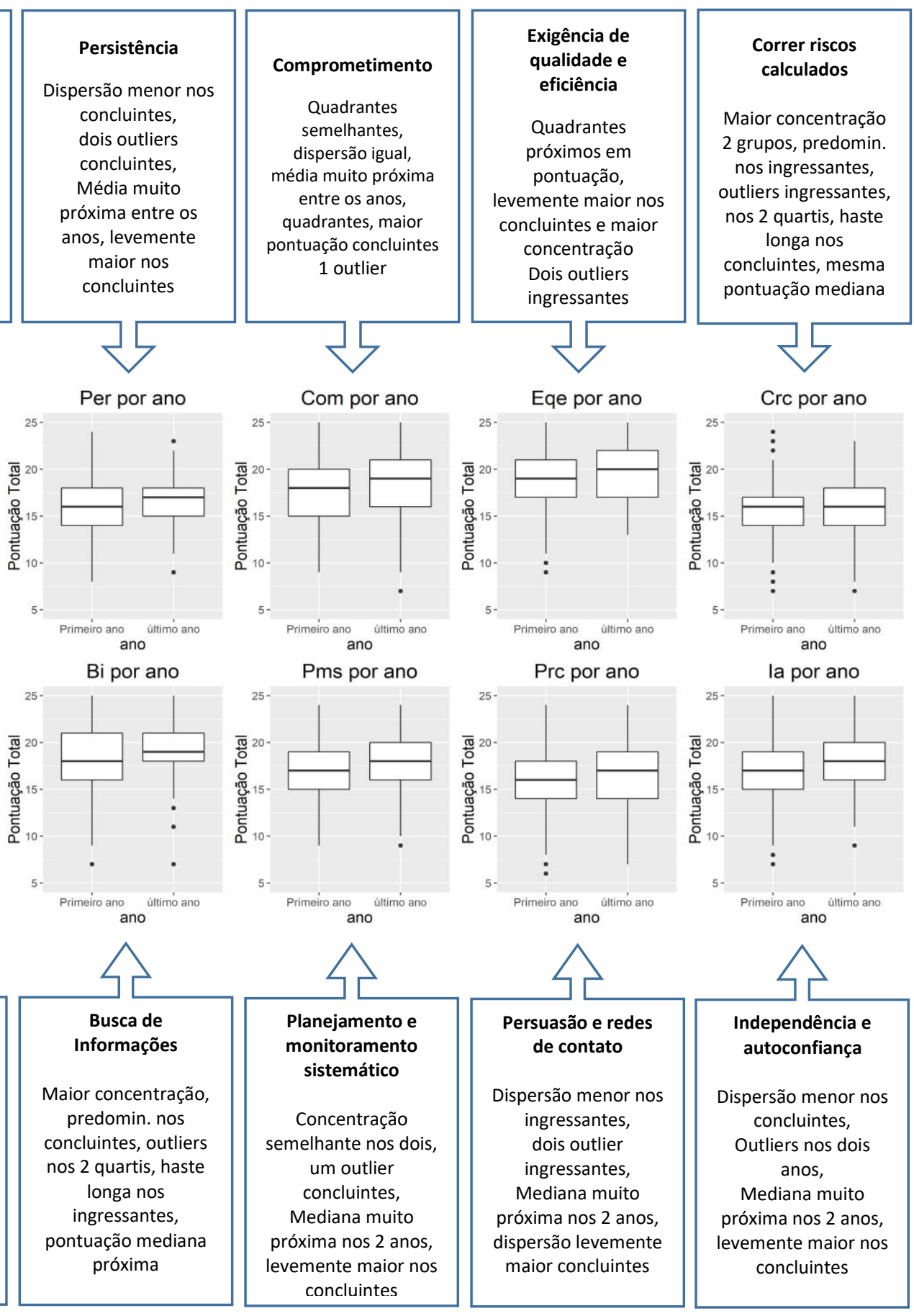

Ilustração 2: Gráfico boxplot das CCE's entre ingressantes e concluintes com boxes explicativos Fonte: Autora

As análises a seguir foram trabalhadas de modo a separar de forma individualizada cada característica, considerando os três cursos e os dois anos, ingressantes e concluintes. 


\subsubsection{Dimensão: Busca de oportunidades e iniciativa}

Segundo McClelland (1987), esta característica envolve certas atitudes do empreendedor, como fazer as coisas antes do solicitado, atuar para expandir o negócio e aproveitar oportunidades fora do comum para iniciar um negócio. Identificar oportunidades, mais do que simplesmente ter ideias, é fundamental para quem deseja ser empreendedor, e consiste em aproveitar todo e qualquer momento para a observação. Além de identificar as oportunidades, o empreendedor deve ter iniciativa, que é a capacidade de se antecipar às situações, agindo de maneira oportuna e adequada sobre a realidade, apresentando soluções e influenciando os acontecimentos futuros. Não haverá empreendimento sem iniciativa, fazer as coisas antes de ser solicitado ou antes de ser forçado pelas circunstâncias, no desenvolvimento do seu trabalho buscar soluções inusitadas para problemas cotidianos, aproveitando oportunidades fora do comum para começar um projeto, conseguir auxilio, parcerias ou assistência. As perguntas do instrumento referente a esta dimensão foram:

- Esforço-me para realizar as coisas que devem ser feitas.

- Faço as coisas que devem ser feitas sem que os outros tenham que me pedir.

- Gosto de desafios e novas oportunidades.

- Prefiro executar tarefas que domino perfeitamente e em que me sinto seguro

- Aventuro-me a fazer coisas novas e diferentes das que fiz no passado.

Os resultados desta dimensão foram:

\begin{tabular}{|c|c|c|c|c|c|}
\hline ano & unidade & $\mathbf{n}$ & mean & sd & Median \\
\hline Ingressantes & Enf-1 & 114 & 16,82 & 3,27 & 17 \\
\hline Concluintes & Enf-1 & 53 & 18,06 & 3,24 & 18 \\
\hline ano & unidade & $\mathbf{n}$ & mean & sd & Median \\
\hline Ingressantes & Enf-2 & 120 & 17,64 & 3,05 & 18 \\
\hline Concluintes & Enf-2 & 53 & 18,74 & 3,42 & 19 \\
\hline ano & unidade & $\mathbf{n}$ & mean & sd & Median \\
\hline Ingressantes & Enf-3 & 43 & 16,51 & 3,62 & 17 \\
\hline Concluintes & Enf-3 & 20 & 17,05 & 3,94 & 18 \\
\hline
\end{tabular}

Quadro 35: Resultados da dimensão: Busca de oportunidades e iniciativa 


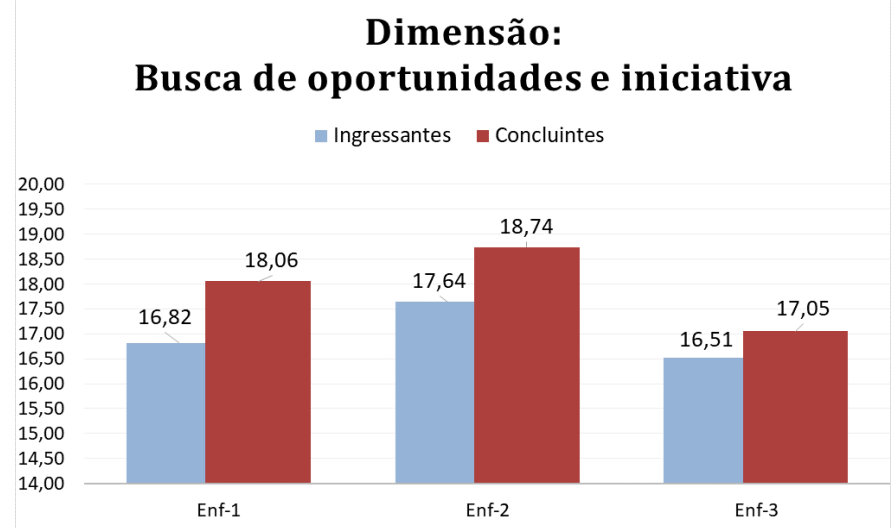

Gráfico 23: Dimensão Busca de oportunidades e iniciativa Fonte: Autora

O gráfico acima traz comparativo das pontuações dos três cursos entre ingressantes e concluintes. Observa-se, assim como os demais gráficos apresentados, que houve um leve aumento dos pontos dos concluintes comparando aos ingressantes, cerca de 1 ponto, o que significa que os alunos concluintes adquiriram algum conhecimento sobre as ações que envolvem busca de oportunidades e iniciativa.

\subsubsection{Dimensão: Persistência}

Ser persistente, segundo McClelland (1987), significa agir diante de um obstáculo significativo, agir repetidamente ou mudar de estratégia, a fim de enfrentar um desafio ou superar um obstáculo e assumir responsabilidade pessoal pelo desempenho necessário ao atingimento de metas e objetivos. Já para Schmidt e Dreher (2008), persistência corresponde ao enfrentamento de desafios e não desistência diante de obstáculos. Nesse sentido, a persistência pode ser considerada a sinergia que leva o indivíduo a agir de diferentes formas, saindo da zona de conforto com o objetivo de atingir sua meta. As perguntas do instrumento referente a esta dimensão foram:

- Quando me deparo com um problema difícil, levo muito tempo para encontrar a solução.

- Insisto várias vezes para conseguir que as outras pessoas façam o que desejo.

- Quando algo se interpõe entre o que eu estou tentando fazer, persisto em minha tarefa.

- Quando me deparo com sérias dificuldades, rapidamente passo para outras atividades.

- Tenho diferentes maneiras de superar obstáculos que se apresentam para a obtenção de minhas metas. 
Os resultados desta dimensão foram:

\begin{tabular}{|c|c|c|c|c|c|}
\hline ano & unidade & $\mathbf{n}$ & mean & sd & median \\
\hline Ingressantes & Enf-1 & 114 & 16,32 & 2,78 & 17 \\
\hline Concluintes & Enf-1 & 53 & 16,17 & 2,91 & 16 \\
\hline ano & unidade & $\mathbf{n}$ & mean & sd & median \\
\hline Ingressantes & Enf-2 & 120 & 16,15 & 3,08 & 16 \\
\hline Concluintes & Enf-2 & 53 & 16,98 & 2,82 & 17 \\
\hline ano & unidade & $\mathbf{n}$ & mean & sd & median \\
\hline Ingressantes & Enf-3 & 43 & 16,44 & 2,48 & 16 \\
\hline Concluintes & Enf-3 & 20 & 16,20 & 2,73 & 16 \\
\hline
\end{tabular}

Quadro 36: Resultados da dimensão: Persistência

\section{Dimensão: Persistência}

- Ingressantes Concluintes

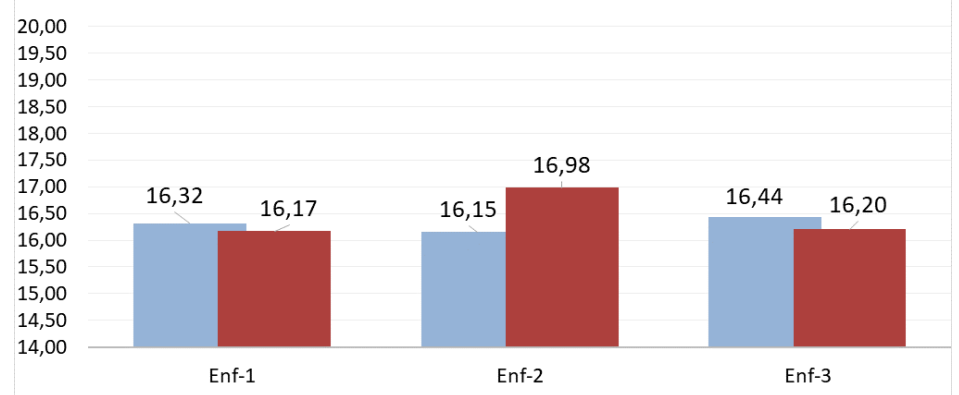

Gráfico 24: Dimensão Persistência Fonte: Autora

O gráfico acima compara as pontuações dos três cursos entre ingressantes e concluintes na dimensão persistência. Observa-se, com os resultados obtidos que as pontuações ficaram bastante próxima no curso Enf-2. Já os cursos Enf-1 e Enf-3 as pontuações de concluintes ficaram menores que os ingressantes levando a crer que a característica persistência teve um declínio para esses dois cursos.

\subsubsection{Dimensão: Comprometimento}

De acordo com McClelland (1987), comprometimento implica fazer um sacrifício pessoal ou despender um esforço extraordinário para completar uma tarefa, bem como colaborar com o próximo ou se colocar no lugar dele, se necessário, para terminar um trabalho. Atribui a si mesmo e a seu comportamento as causas de seus sucessos ou fracassos e assume responsabilidade pessoal pelos resultados obtidos. Colabora com seus parceiros 
ou coloca-se no lugar deles, se necessário, para terminar um trabalho. Age disposto a fazer mais do que suas atribuições (profissionais), e em seu ambiente de trabalho busca melhores resultados. Nesse sentido, os alunos que evidenciaram essa característica indicam assumir responsabilidades e exercer suas atividades com dedicação.

As perguntas do instrumento relacionadas a essa dimensão foram:

- Termino meu trabalho ou atividade a tempo.

- Sou fiel às promessas que faço.

- Se necessário não me importo de fazer o trabalho dos outros para cumprir um prazo de entrega.

- Quando estou fazendo um trabalho para outra pessoa, me esforço de forma especial para que fique satisfeita com o trabalho.

- Minha família e vida pessoal são mais importantes para mim do que as datas de entregas de trabalho determinadas por mim mesmo.

Os resultados desta dimensão foram:

\begin{tabular}{|c|c|c|c|c|c|}
\hline ano & unidade & $\mathbf{n}$ & mean & sd & median \\
\hline Ingressantes & Enf-1 & 114 & 17,83 & 3,20 & 18 \\
\hline Concluintes & Enf-1 & 53 & 17,72 & 3,54 & 18 \\
\hline ano & unidade & $\mathbf{n}$ & mean & sd & median \\
\hline Ingressantes & Enf-2 & 120 & 17,78 & 3,43 & 18 \\
\hline Concluintes & Enf-2 & 53 & 18,77 & 3,58 & 20 \\
\hline ano & unidade & $\mathbf{n}$ & mean & sd & median \\
\hline Ingressantes & Enf-3 & 43 & 18,28 & 3,35 & 17 \\
\hline Concluintes & Enf-3 & 20 & 17,80 & 5,61 & 20,5 \\
\hline
\end{tabular}

Quadro 37: Resultados da dimensão: Comprometimento 


\section{Dimensão: Comprometimento}

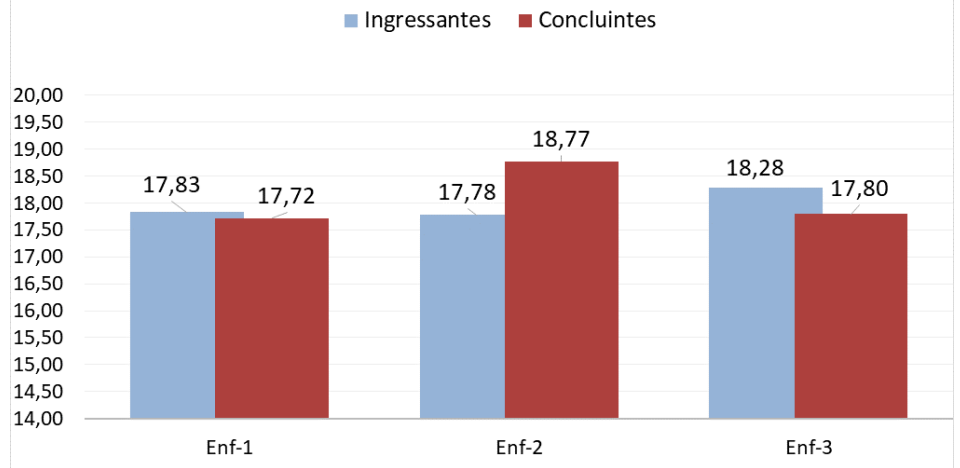

Gráfico 25: Dimensão Comprometimento Fonte: Autora

O gráfico acima compara as pontuações dos três cursos entre ingressantes e concluintes na dimensão comprometimento. Observa-se, assim como os demais gráficos apresentados, que houve um leve aumento dos pontos dos concluintes apenas do curso Enf2, já os cursos Enf-1 e Enf-3 tiveram um declínio nos números o que corresponde a uma interpretação de que o fator comprometimento dos concluintes caiu em relação aos ingressantes. A dimensão comprometimento foi mais evidenciada no curso Enf-2 o que significa que os alunos concluintes deste curso adquiriram alguma habilidade correspondente à dimensão comprometimento.

\subsubsection{Dimensão: Exigência de qualidade e eficiência}

Segundo McClelland (1987), esta dimensão tem como características encontrar maneiras de fazer as coisas melhor, de forma mais rápida, ou mais barata ou mesmo que traga algum diferencial; agir de maneira a fazer as coisas que satisfazem ou excedem padrões de excelência; desenvolvem ou utilizam procedimentos para assegurar que o trabalho seja finalizado a tempo ou que o trabalho atenda padrões de qualidade previamente combinados ou os superem. Esta característica representa a paixão dos empreendedores exitosos, que sempre buscam uma forma de melhorar o que fazem, diminuir o tempo, reduzir os custos.

As perguntas do instrumento relacionadas a essa dimensão foram:

- Aborreço-me quando as coisas não são feitas devidamente. 
- Meu rendimento no trabalho / atividades é melhor do que o das outras pessoas com quem trabalho.

- Aborreço-me quando perco tempo.

- Nunca fico realmente satisfeito com a forma como são deitas as coisas; sempre considero que há uma maneira melhor de fazê-las.

- Encontro a maneira mais rápida de terminar os trabalhos, tanto em casa quanto no trabalho ou faculdade.

Os resultados desta dimensão foram:

\begin{tabular}{|c|c|c|c|c|c|}
\hline Ano & unidade & $\mathbf{n}$ & mean & sd & median \\
\hline Ingressantes & Enf-1 & 114 & 19,74 & 2,74 & 20 \\
\hline Concluintes & Enf-1 & 53 & 19,02 & 3,26 & 19 \\
\hline Ano & unidade & $\mathbf{n}$ & mean & sd & median \\
\hline Ingressantes & Enf-2 & 120 & 18,43 & 3,14 & 18 \\
\hline Concluintes & Enf-2 & 53 & 19,47 & 2,92 & 20 \\
\hline Ano & unidade & $\mathbf{n}$ & mean & sd & median \\
\hline Ingressantes & Enf-3 & 43 & 18,40 & 3,38 & 19 \\
\hline Concluintes & Enf-3 & 20 & 19,90 & 2,29 & 20 \\
\hline
\end{tabular}

Quadro 38: Resultado da dimensão: Exigência de qualidade e eficiência

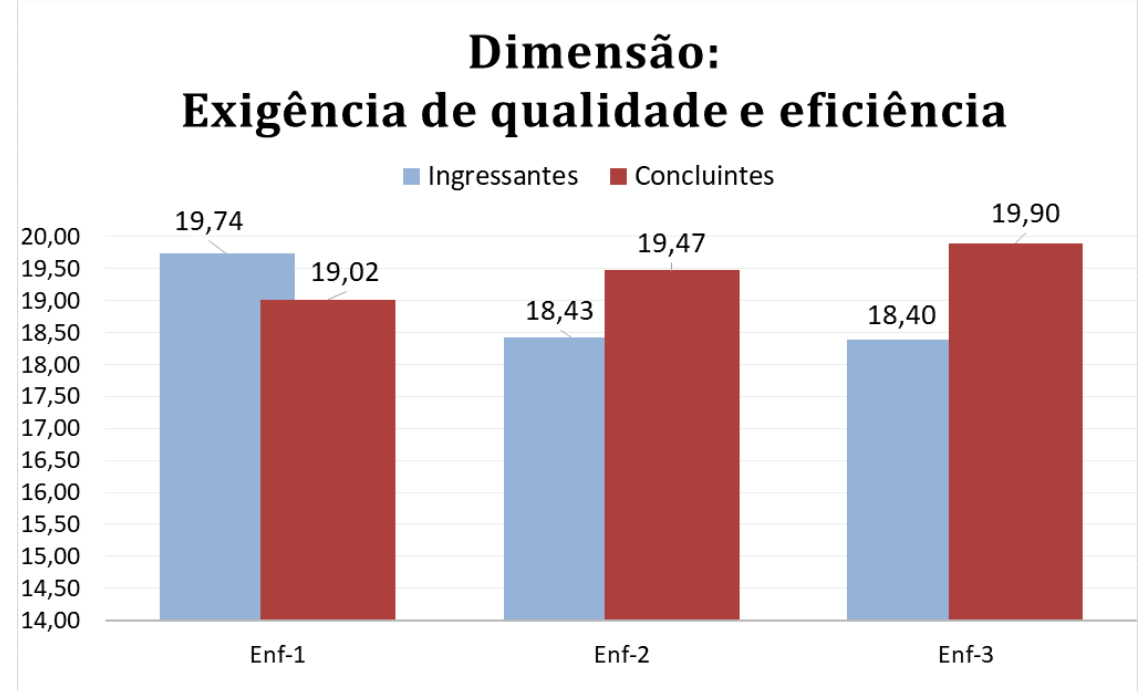

Gráfico 26: Dimensão Comprometimento

Fonte: Autora

O gráfico acima compara as pontuações dos três cursos entre ingressantes e concluintes na dimensão exigência de qualidade e eficiência. Observa-se, assim como os demais gráficos apresentados, que houve um aumento dos pontos dos concluintes em relação aos ingressantes, dos cursos Enf-2 e Enf-3. Já o curso Enf-1 nesta dimensão nota-se 
uma regressão dos números, o que nos leva a crer que na dimensão Exigência de qualidade e eficiência os alunos concluintes têm essa percepção menos evidenciada que nos ingressantes.

\subsubsection{Dimensão: Correr riscos calculados}

Segundo McClelland (1987), é plausível que toda atividade empresarial envolva algum risco, tendo em vista as incertezas que fazem parte da missão de empreender em um negócio, razão pela qual não fosse assim as empresas não enfrentariam dificuldades que enfrentam ou até mesmo ir à falência. É por esta razão, dos riscos de se investir numa nova ideia ou um novo negócio, que as atividades produtivas devem oferecer uma rentabilidade condizente com o capital investido. $\mathrm{O}$ empreendedor precisa se basear mais em ferramentas de análise do que somente na sua intuição ou visão, que também não deve ser desprezada, buscar avaliar os riscos para poder minimizá-los ou até mesmo saná-los. É a característica que faz com que os empreendedores avaliem as alternativas antes da ação. Dessa forma, são capazes de enfrentar desafios sem colocar tudo a perder agindo de forma impensada.

As perguntas do instrumento relacionadas a essa dimensão foram:

- Prefiro situações em que posso controlar ao máximo o resultado final.

- Envolvo-me com algo novo só depois de ter feito o possível para assegurar seu êxito.

- Considero minhas possibilidades de êxito ou fracasso antes de começar atuar.

- Executo tarefas arriscadas.

- Faço coisas que as outras pessoas consideram arriscadas.

Os resultados desta dimensão foram:

\begin{tabular}{|c|c|c|c|c|c|}
\hline ano & Unidade & $\mathbf{n}$ & mean & sd & median \\
\hline Ingressantes & Enf-1 & 114 & 15,66 & 2,63 & 16 \\
\hline Concluintes & Enf-1 & 53 & 15,28 & 2,72 & 15 \\
\hline ano & unidade & $\mathbf{n}$ & mean & sd & median \\
\hline Ingressantes & Enf-2 & 120 & 15,31 & 2,87 & 15 \\
\hline Concluintes & Enf-2 & 53 & 15,85 & 2,85 & 16 \\
\hline ano & unidade & $\mathbf{n}$ & mean & sd & median \\
\hline Ingressantes & Enf-3 & 43 & 15,65 & 3,78 & 16 \\
\hline Concluintes & Enf-3 & 20 & 16,95 & 3,30 & 18 \\
\hline
\end{tabular}

Quadro 39: Resultados da dimensão: Correr riscos calculados 


\section{Dimensão: Correr riscos calculados}

- Ingressantes Concluintes

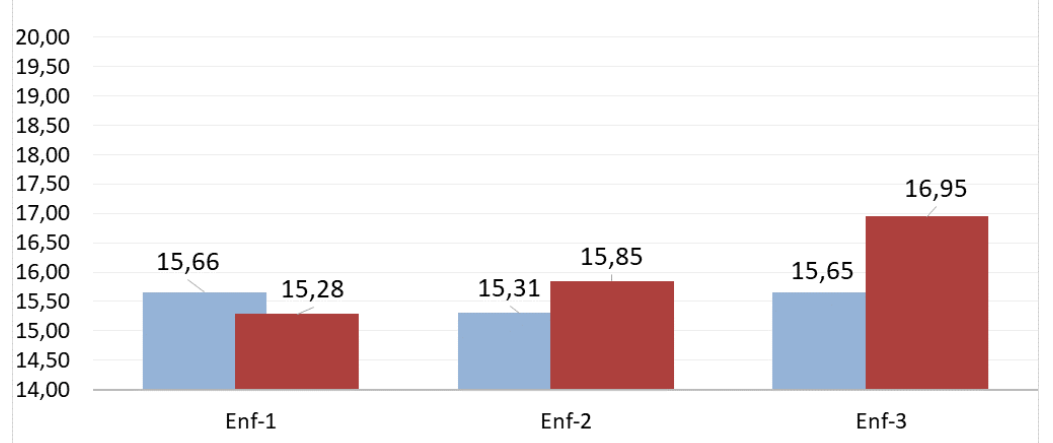

Gráfico 27: Dimensão Comprometimento Fonte: Autora

O gráfico acima compara as pontuações dos três cursos entre ingressantes e concluintes na dimensão correr riscos calculados. Observa-se, assim como os demais gráficos, que esta característica foi a que obteve menor índice tanto de ingressantes como de concluintes, não havendo avanços nos números, salvo o curso Enf-3 que apresentou uma pontuação diferenciada para os concluintes, em comparação com os ingressantes, porém ainda menor em relação às demais dimensões. De modo geral e apesar de sutil, os alunos concluintes adquiriram alguma habilidade correspondente a dimensão correr riscos calculados.

\subsubsection{Dimensão: Estabelecimento de metas}

Segundo McClelland (1987), esta característica envolve certas atitudes do empreendedor, como: estabelecer metas e objetivos que são desafiantes e que têm significado pessoal; definir metas de longo prazo, claras e específicas; e estabelecer objetivos de curto prazo mensuráveis. Os empreendedores de sucesso são pessoas que registram tudo o que querem fazer, procuram estabelecer prazos e se monitoram para atingir as metas dentro dos prazos estabelecidos. São pessoas organizadas e tendem a ser metódicas com suas ações e com seu trabalho, muitas vezes criando rotinas sistemáticas para facilitar sua forma de agir. Estabelecimento de Metas para Mc Clelland é o motor dos empreendedores sendo uma característica essencial ao seu perfil.

As perguntas do instrumento relacionadas a essa dimensão foram: 
- Gosto de pensar no futuro.

- Acho uma perda de tempo me preocupar com o que farei daminha vida

- Quanto mais especificas forem minhas expectativas em relação ao que quero obter na vida, maiores serão minhas possibilidades de êxito.

- Conto com um plano claro de vida.

- Preocupo-me tanto em alcançar minhas metas semanais quanto minhas metas anuais

Os resultados desta dimensão foram:

\begin{tabular}{|c|c|c|c|c|c|}
\hline ano & unidade & $\mathbf{n}$ & Mean & sd & median \\
\hline Ingressantes & Enf-1 & 114 & 19,18 & 3,47 & 19 \\
\hline Concluintes & Enf-1 & 53 & 19,04 & 3,37 & 20 \\
\hline ano & unidade & $\mathbf{n}$ & mean & sd & median \\
\hline Ingressantes & Enf-2 & 120 & 19,37 & 3,55 & 20 \\
\hline Concluintes & Enf-2 & 53 & 20,02 & 2,84 & 20 \\
\hline ano & unidade & $\mathbf{n}$ & mean & sd & median \\
\hline Ingressantes & Enf-3 & 43 & 19,16 & 3,58 & 20 \\
\hline Concluintes & Enf-3 & 20 & 20,85 & 2,98 & 20 \\
\hline
\end{tabular}

Quadro 40: Resultados da dimensão: Estabelecimento de metas

\section{Dimensão: Estabelecimento de metas}

घ Ingressantes $\square$ Concluintes

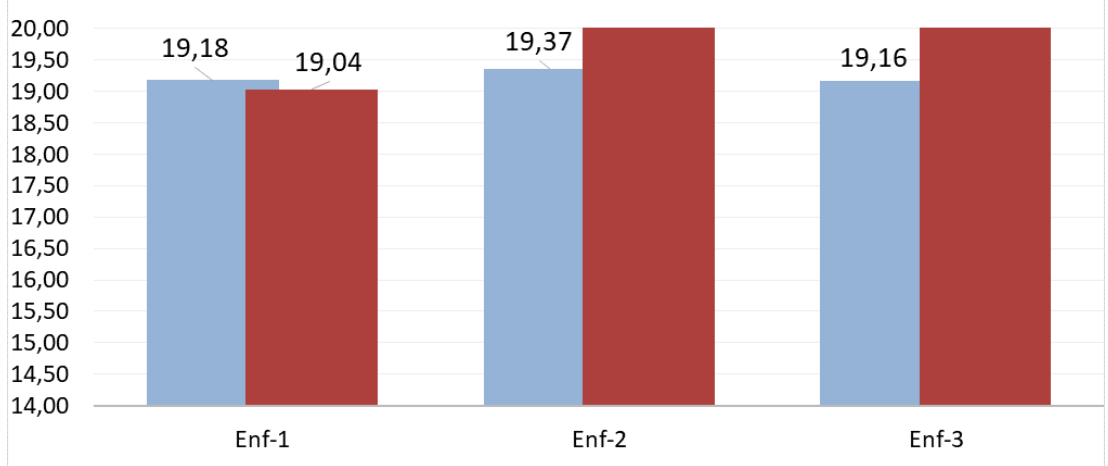

Gráfico 28: Dimensão Comprometimento Fonte: Autora

O gráfico acima compara as pontuações dos três cursos entre ingressantes e concluintes na dimensão estabelecimento de metas. Observa-se, assim como os demais gráficos apresentados, que esta característica foi a que obteve maior índice tanto de ingressantes como de concluintes. De modo geral e apesar de sutil, os alunos concluintes 
adquiriram alguma habilidade correspondente à dimensão estabelecimento de metas. Outra observação importante para esta dimensão refere-se ao fato de os alunos ingressantes já terem tido um resultado bastante satisfatório, todos os três cursos com pontuação acima de 19 pontos o que eleva o grau de ponderação considerando a média de pontuações das demais dimensões. Os alunos concluintes dos cursos Enf-2 e Enf-3 tiveram resultados acima de 20 pontos o que sinaliza estarem no patamar de pontuação acima do nível satisfatório.

\subsubsection{Dimensão: Busca de informações}

A informação é uma ferramenta muito utilizada para sobressair-se no mercado e o empreendedor, para McClelland (1987) dedica-se pessoalmente a obter informações de clientes, fornecedores e concorrentes; investiga pessoalmente como fabricar um produto ou proporcionar um serviço; e consulta especialistas para obter assessoria técnica ou comercial. Os empreendedores de sucesso são pessoas curiosas, perguntam tudo a todos: clientes, concorrentes, fornecedores. Estão sempre interagindo com o mercado. Busca de informações é a pedra angular e a base de toda atividade exitosa.

As perguntas do instrumento relacionadas a essa dimensão foram:

- Quando começo uma tarefa ou projeto novo, coleto todas as informações possíveis antes de dar prosseguimento a ele.

- Procuro conselhos das pessoas que são especialistas no ramo em que estou atuando.

- Tomo decisões sem perder tempo buscando informações.

- Quando executo um projeto para alguém, faço muitas perguntas para assegurar-me de que entendi o que quer.

- Conto com várias fontes de informação ao procurar ajuda para a execução de tarefas e projetos.

Os resultados desta dimensão foram:

\begin{tabular}{|c|c|c|c|c|c|}
\hline ano & unidade & $\mathbf{n}$ & mean & sd & median \\
\hline Ingressantes & Enf-1 & 114 & 18,54 & 3,17 & 18,5 \\
\hline Concluintes & Enf-1 & 53 & 19,66 & 2,93 & 19 \\
\hline
\end{tabular}

\begin{tabular}{|c|c|c|c|c|c|}
\hline ano & unidade & $\mathbf{n}$ & mean & sd & median \\
\hline Ingressantes & Enf-2 & 120 & 17,68 & 3,69 & 17,5 \\
\hline Concluintes & Enf-2 & 53 & 19,11 & 3,34 & 19 \\
\hline
\end{tabular}




\begin{tabular}{|c|c|c|c|c|c|}
\hline ano & unidade & $\mathbf{n}$ & mean & sd & median \\
\hline Ingressantes & Enf-3 & 43 & 19,07 & 2,82 & 20 \\
\hline Concluintes & Enf-3 & 20 & 19,45 & 3,33 & 19 \\
\hline
\end{tabular}

Quadro 41: Resultados da dimensão: Busca de informações

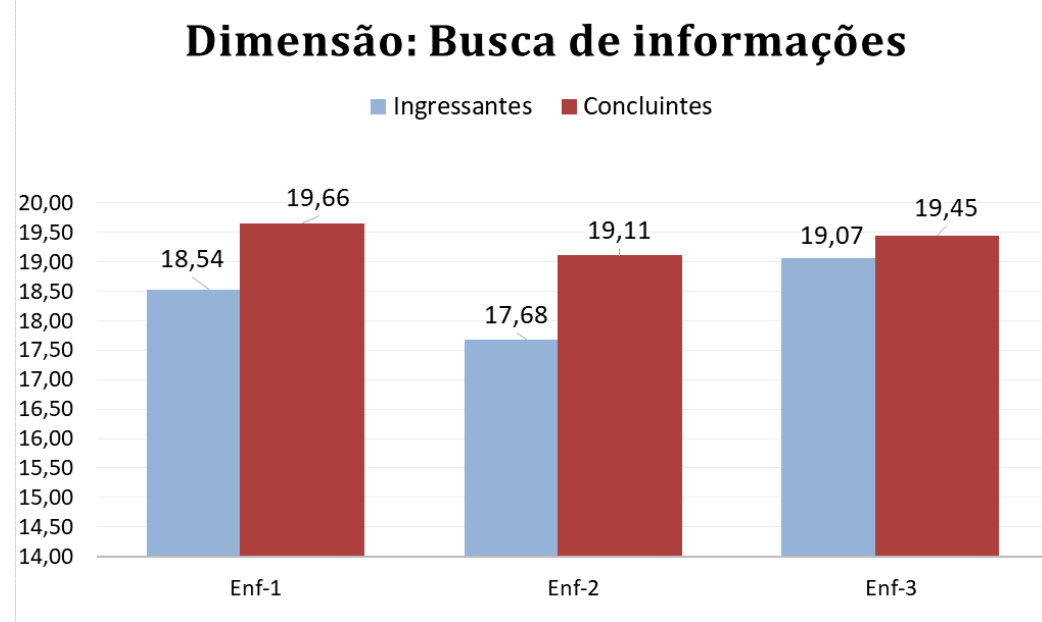

Gráfico 29: Dimensão Comprometimento Fonte: Autora

O gráfico compara as pontuações dos três cursos entre ingressantes e concluintes na dimensão busca de informações. Observa-se, assim como os demais gráficos apresentados, que esta característica foi uma das que obteve pontuação satisfatória tanto de ingressantes como de concluintes, com pontuações melhores nos concluintes nos cursos Enf-1 e Enf-2. De modo geral e apesar de sutil, os alunos concluintes adquiriram habilidade correspondente a dimensão busca de informações.

\subsubsection{Dimensão: Planejamento e monitoramento sistemáticos}

Para McClelland (1987), a característica de planejamento e monitoramento sistemático está presente no indivíduo que organiza tarefas de maneira objetiva, com prazos definidos, a fim de que possa avaliar e mensurar os resultados. Dessa forma, enquanto significado de processo e de construção, o planejamento é uma dimensão fundamental para o trabalho pedagógico, porque permite aos professores e à instituição de ensino controlar os resultados e a consecução das finalidades desse trabalho. 
Segundo McClelland, por meio dessa característica, o empreendedor é capaz de dividir tarefas de grande porte em subtarefas com prazos definidos; revisar seus planos constantemente, levando em conta os resultados obtidos e mudanças circunstanciais; e mantém registros financeiros, utilizando-os para tomar decisões. 0 empreendedor é alguém com capacidade de observação, de planejamento e de mapear o meio ambiente, analisando recursos e condições existentes, buscando estruturar uma visão de longo prazo dos rumos a serem seguidos para se atingir os objetivos. O empreendedor faz um planejamento por meio da elaboração do plano de negócios do seu empreendimento e com esse documento consegue avaliar o negócio, monitorar com o acompanhamento sistemático e comparativo, e consegue atrair investidores para seu projeto, ou seja, buscar recursos financeiros e parceiros de uma maneira geral. O planejamento é o mapa dos empreendedores, um guia valioso, contudo, difícil de ser executado por ser uma tarefa quieta que exige pensamento e concentração, e os empreendedores gostam de fazer, de realizar, de estar na linha de frente. Agora, é sabido que os melhores resultados sempre ficam ao lado daqueles que planejam.

As perguntas do instrumento relacionadas a essa dimensão foram:

- Planejo um projeto grande dividindo-o em tarefas mais simples.

- Considero cuidadosamente as vantagens e desvantagens de diferentes alternativas

- Trato de levar em conta todos os problemas que podem se apresentar e antecipo o que eu faria caso sucedam.

- Enfrento os problemas na medida em que surgem, em vez de antecipá-los.

- Se determinado método para enfrentar um problema não der certo, recorro a outro.

Os resultados desta dimensão foram:

\begin{tabular}{|c|c|c|c|c|c|}
\hline ano & unidade & $\mathbf{n}$ & mean & sd & median \\
\hline Ingressantes & Enf-1 & 114 & 17,44 & 3,07 & 18 \\
\hline Concluintes & Enf-1 & 53 & 18,08 & 2,75 & 18 \\
\hline ano & unidade & $\mathbf{n}$ & mean & sd & median \\
\hline Ingressantes & Enf-2 & 120 & 16,22 & 2,86 & 16 \\
\hline Concluintes & Enf-2 & 53 & 17,98 & 3,07 & 19 \\
\hline ano & unidade & $\mathbf{n}$ & mean & sd & median \\
\hline Ingressantes & Enf-3 & 43 & 16,77 & 2,65 & 17 \\
\hline Concluintes & Enf-3 & 20 & 17,40 & 2,11 & 18 \\
\hline
\end{tabular}

Quadro 42: Resultados da dimensão: Planejamento e monitoramento sistemáticos 
Dimensão: Planejamento e monitoramento sistemáticos

Ingressantes Concluintes

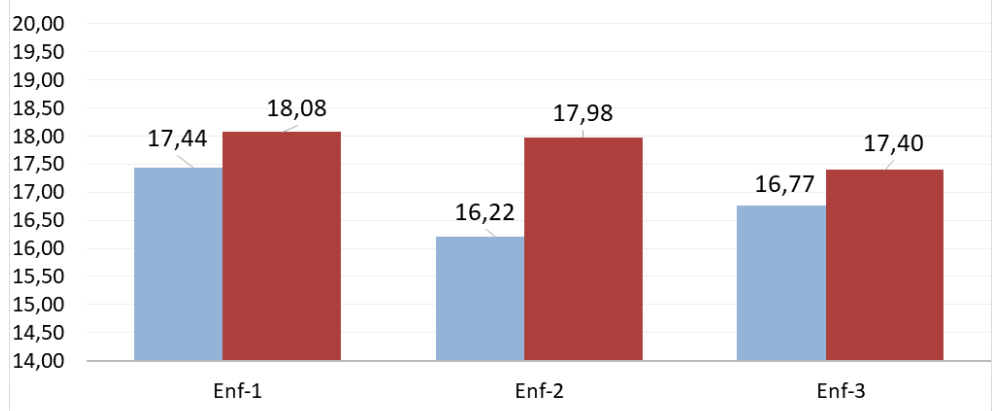

Gráfico 30: Dimensão Comprometimento Fonte: Autora

O gráfico acima compara pontuações dos três cursos entre ingressantes e concluintes na dimensão planejamento e monitoramento sistemático. Observa-se, assim como os demais gráficos apresentados, que esta característica foi desenvolvida no transcorrer dos cursos, apesar de não terem tido a disciplina específica. Os números mostram melhor avanço no curso Enf-2 comparando ingressantes e concluintes. De modo geral e apesar de sutil, os alunos concluintes adquiriram habilidade correspondente à dimensão planejamento e monitoramento sistemático.

\subsubsection{Dimensão: Persuasão e redes de contato}

Com tal característica o empreendedor utiliza estratégias deliberadas para influenciar ou persuadir os outros e se relaciona com pessoas chave como agentes para atingir seus objetivos; age para desenvolver e manter relações de network (redes de contato profissional), segundo McClelland (1987). O empreendedor busca ampliar sua rede de relações e manter contato constante com todos os membros. Vê nas pessoas uma das suas mais importantes fontes de aprendizagem, e não se prende somente a fontes reconhecidas, como autores da literatura, cursos, profissionais especialistas, etc. Busca extrair das pessoas informações, aconselhamentos, experiências já vividas (para não cometer os mesmos erros), obter parcerias, influências, etc. Os empreendedores de sucesso estão sempre em contato com o maior número de pessoas possível. Têm a capacidade de identificar em outras pessoas pontos para multiplicar sua base de ação e realização. 
As perguntas do instrumento relacionadas a essa dimensão foram:

- Consigo que os outros me apoiem em minhas recomendações.

- Não perco muito tempo pensando em como posso influenciar as outras pessoas.

- Conto com pessoas influentes para alcançar minhas metas.

- Para alcançar minhas metas, procuro soluções que beneficiem todas as pessoas envolvidas em um problema.

- Posso conseguir que pessoas com firmes convicções e opiniões mudem seu modo de pensar.

Os resultados desta dimensão foram:

\begin{tabular}{|c|c|c|c|c|c|}
\hline ano & unidade & $\mathbf{N}$ & mean & sd & median \\
\hline Ingressantes & Enf-1 & 114 & 16,37 & 3,19 & 16 \\
\hline Concluintes & Enf-1 & 53 & 16,00 & 2,99 & 16 \\
\hline ano & unidade & $\mathbf{n}$ & mean & sd & median \\
\hline Ingressantes & Enf-2 & 120 & 16,20 & 3,38 & 16 \\
\hline Concluintes & Enf-2 & 53 & 16,94 & 3,46 & 18 \\
\hline ano & unidade & $\mathbf{n}$ & mean & sd & median \\
\hline Ingressantes & Enf-3 & 43 & 14,95 & 3,82 & 15 \\
\hline Concluintes & Enf-3 & 20 & 15,80 & 4,74 & 17 \\
\hline
\end{tabular}

Quadro 43: Resultados da dimensão: Persuasão e redes de contato

Dimensão: Persuasão e redes de contato

Ingressantes Concluintes

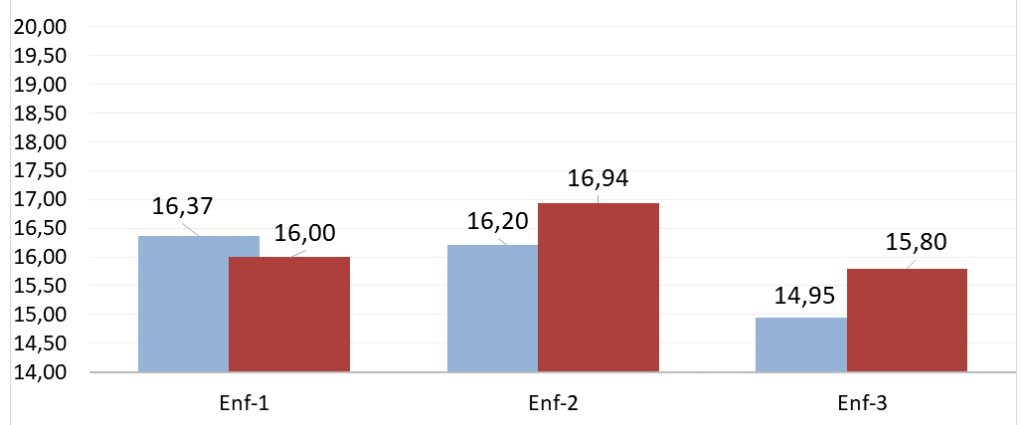

Gráfico 31: Dimensão Comprometimento

Fonte: Autora

O gráfico acima compara as pontuações dos três cursos entre ingressantes e concluintes na dimensão persuasão e rede de contatos. Observa-se, assim como os demais gráficos apresentados, que esta característica foi uma das que resultarem em menor 
pontuação tanto com ingressantes quanto com concluintes, com pontuações baixas em relação às demais características. De modo geral e apesar de sutil, os alunos concluintes adquiriram habilidade correspondente a dimensão persuasão e rede de contatos.

\subsubsection{Dimensão: Independência e autoconfiança}

Segundo McClelland (1987), a dimensão independência e autoconfiança baseia-se na capacidade de buscar autonomia em relação a normas e controles impostos, mantém seu ponto de vista mesmo diante da oposição ou de resultados desanimadores e expressam confiança na própria capacidade de completar uma tarefa difícil ou de enfrentar um desafio. Autoconfiança é ter consciência de seu valor, sentir-se seguro em relação a si mesmo e, com isso, poder agir com firmeza e tranquilidade. A crença em si mesmo, ou seja, a autoconfiança faz o indivíduo arriscar mais, ousar, oferecer-se para realizar tarefas desafiadoras. O desejo de liberdade/independência, associado à autoconfiança, leva o empreendedor a trocar a segurança do salário, pelo risco de um negócio próprio. Esta é a consequência de todas as outras características, não a fonte. Os empreendedores são otimistas, quando as coisas não dão certo, mantêm a confiança, vão sempre em frente por acreditarem na sua própria capacidade de realizar aquilo a que se propõem.

As perguntas do instrumento relacionadas a essa dimensão foram:

- Tenho confiança que posso estar bem-sucedido em qualquer atividade que me proponha executar.

- Mudo a maneira de pensar se os outros discordam energicamente dos meus pontos de vista.

- Quando estou executando algo difícil e desafiador, tenho confiança em seu sucesso.

- O trabalho que realizo é excelente.

- Mantenho-me firme em minhas decisões, mesmo quando as outras pessoas se opõem energicamente. 
Os resultados desta dimensão foram:

\begin{tabular}{|c|c|c|c|c|c|}
\hline ano & Unidade & $\mathbf{n}$ & mean & sd & median \\
\hline Ingressantes & Enf-1 & 114 & 15,38 & 3,58 & 15,5 \\
\hline Concluintes & Enf-1 & 53 & 16,04 & 2,85 & 16 \\
\hline ano & unidade & $\mathbf{n}$ & mean & sd & median \\
\hline Ingressantes & Enf-2 & 120 & 17,48 & 2,76 & 17 \\
\hline Concluintes & Enf-2 & 53 & 19,02 & 3,23 & 19 \\
\hline ano & unidade & $\mathbf{n}$ & mean & sd & median \\
\hline Ingressantes & Enf-3 & 43 & 18,26 & 4,18 & 18 \\
\hline Concluintes & Enf-3 & 20 & 17,85 & 4,21 & 18,5 \\
\hline
\end{tabular}

Quadro 44: Resultados da dimensão: Independência e autoconfiança

\section{Dimensão: Independência e autoconfiança}

Ingressantes concluintes

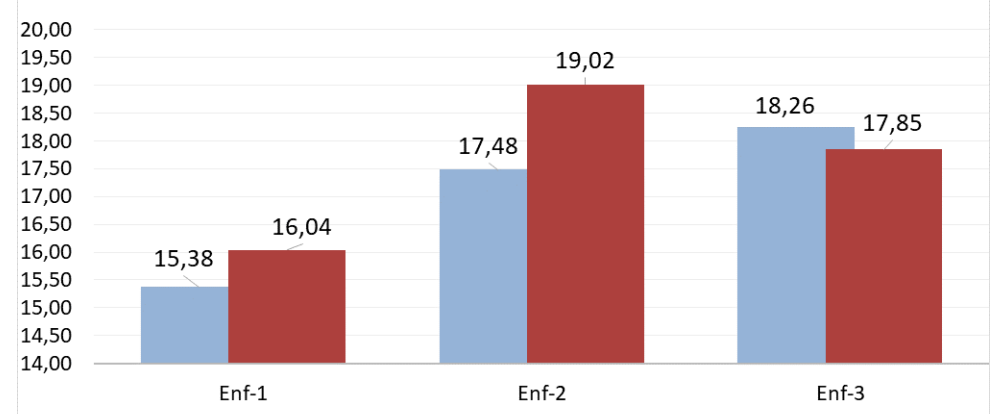

Gráfico 32: Dimensão Comprometimento

Fonte: Autora

O gráfico acima compara as pontuações dos três cursos entre ingressantes e concluintes na dimensão independência e autoconfiança. Observa-se, assim como os demais gráficos apresentados, que esta característica teve um sutil aumento no porcentual dos concluintes frente aos números dos ingressantes nos cursos Enf-1 e Enf-2, com uma pontuação substantiva no curso Enf-2 que, além de ter um acréscimo nos concluintes, percebe-se que a pontuação dos ingressantes se coloca diferenciada. Já com o curso denominado Enf-3 os números mostram um retrocesso uma vez que o percentual obtido com alunos ingressantes, 18,26, foi sutilmente maior que o número obtido com alunos concluintes, de 17,85. De modo geral e apesar de sutil, os alunos concluintes adquiriram habilidade correspondente a dimensão independência e autoconfiança. 


\subsubsection{Considerações acerca da pesquisa quantitativa}

Na pesquisa quantitativa obteve-se os resultados das dimensões do instrumento de McClelland considerando as características comportamentais empreendedoras. Pela média, observou-se que algumas dimensões teve um resultado mais alto o que significa que a característica da dimensão foi desenvolvida nos alunos dos cursos pesquisados.

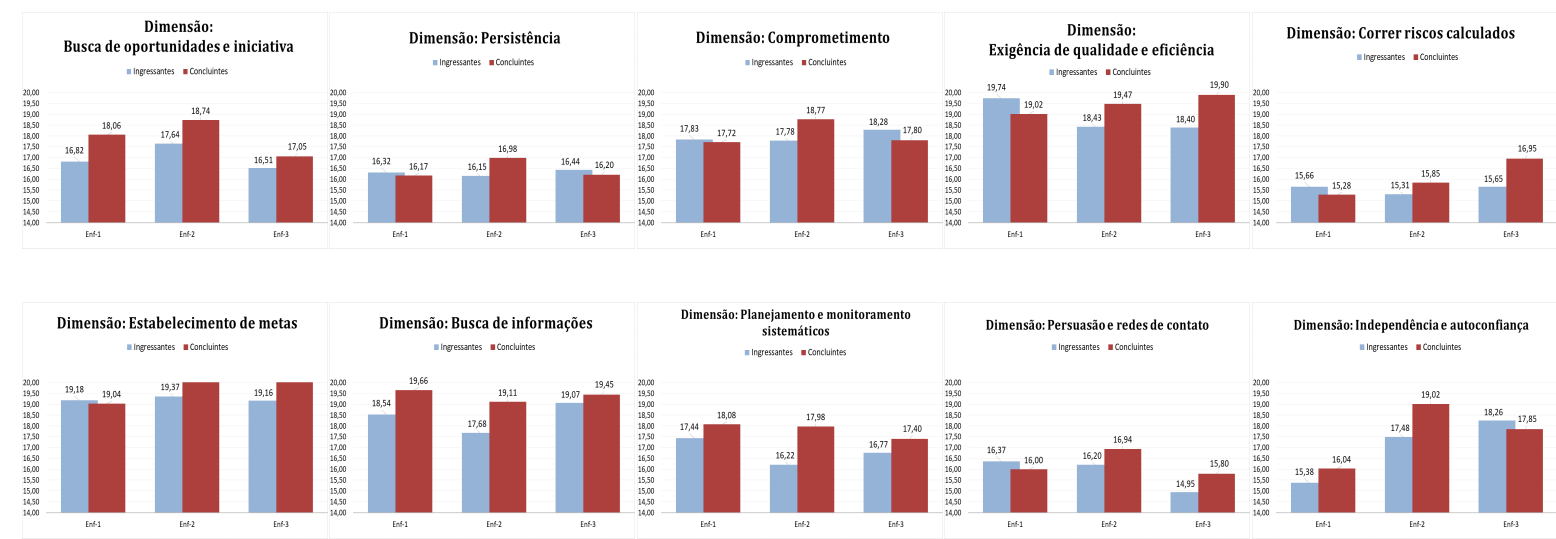

Gráfico 33: Compilado dos gráficos das dimensões das CCE’'s Fonte: Autora

Este compilado, separados por dimensão e por curso e ano ilustra de forma sintetizada, os avanços e retrocessos dos resultados da pesquisa quantitativa e com eles pode-se aferir dimensões onde os alunos desenvolveram habilidades empreendedoras, outras se mantiveram e outras, pelos números, retrocederam.

Por este compilado, observa-se que as dimensões "exigência de qualidade e eficiência" e "estabelecimento de metas" foram dimensões bem pontuadas tanto de ingressantes como de concluintes. Já as dimensões "correr riscos calculados" e "persuasão e redes de contato" ao contrário das anteriores, mostraram os menores números tanto de ingressantes como de concluintes. Os gráficos mostrados desta forma, agrupados, proporciona uma visão do todo, que favorece a interpretação que esta etapa da pesquisa se propôs a realizar. Em resposta à pergunta de pesquisa do presente estudo, pode-se constatar pelos resultados da pesquisa quantitativa, que o grau de empreendedorismo segundo a teoria das CCE's de David McClelland os alunos encontram-se num patamar de perfil empreendedor de nível inferior, com poucas habilidades empreendedoras desenvolvidas e recomenda-se sua inserção nas atividades disciplinares ou mesmo a inserção de disciplina específica sobre o tema. 
A seguir tem-se a etapa de pesquisa qualitativa.

\subsection{Análise da Abordagem Qualitativa}

Na pesquisa qualitativa, as respostas foram compiladas utilizando software Excel para tabulação das respostas. Foram analisadas todas as respostas, inclusive aquelas sem nenhum conteúdo (em branco) ou mesmo com respostas do tipo "não sei opinar" e incompletas do tipo "empreendedorismo é...", por entender que este tipo de participação, mesmo nula, ilustra o grau de conhecimento, ou desconhecimento do participante.

A partir dessas análises foi possível o agrupamento das respostas baseadas nos termos mais utilizados, levando em conta o processo afunilativo das interpretações. Vale ressaltar que a análise buscou identificar apenas um termo, símbolo, por resposta, ou por respondente, sendo assim, o número de inferências estará convergente com os números de participantes da pesquisa. A tabela a seguir traz o agrupamento com base nos termos encontrados com maior frequência, considerando o processo de análise de conteúdo por categorização e enunciação, conforme descrito nos procedimentos da pesquisa:

\begin{tabular}{|c|c|c|c|c|c|}
\hline TERMOS & Inferências & Enf-1 & Enf-2 & Enf-3 & Percentual \\
\hline Assumir riscos & 6 & 2 & 4 & 0 & \\
\hline Atingir metas & 9 & 7 & 0 & 2 & \\
\hline Conhecimento & 4 & 0 & 4 & 1 & \\
\hline Criatividade & 5 & 1 & 1 & 3 & \\
\hline Em branco & 61 & 14 & 36 & 11 & $15 \%$ \\
\hline Gerenciar um negócio & 29 & 15 & 5 & 9 & $7 \%$ \\
\hline Iniciativa & 4 & 1 & 2 & 1 & \\
\hline Inovação & 57 & 36 & 13 & 8 & $14 \%$ \\
\hline Investimento & 48 & 24 & 24 & 0 & $12 \%$ \\
\hline Objetivos de vida & 6 & 4 & 2 & 0 & \\
\hline Pensar no futuro & 4 & 1 & 2 & 1 & \\
\hline Persistência & 25 & 9 & 12 & 4 & $6,2 \%$ \\
\hline Persuasão & 4 & 2 & 3 & 0 & \\
\hline Profissão & 1 & 0 & 1 & 0 & \\
\hline Realizar projetos & 7 & 4 & 3 & 0 & \\
\hline Sucesso profissional & 4 & 1 & 1 & 2 & \\
\hline Ter seu próprio negócio & 129 & 52 & 56 & 21 & $32 \%$ \\
\hline TOTAL & 403 & & & & \\
\hline
\end{tabular}

Quadro 45: Resultado da pesquisa qualitativa

Fonte: Autora 
Pode-se aferir que os termos: "gerenciar um negócio", "inovação", "investimento", "persistência", "ter seu próprio negócio" e "em branco" foram os de maior número, ou seja, de maior relevância, com base nas respostas dos participantes. Já termos como: assumir riscos; atingir metas; conhecimento; criatividade; iniciativa; objetivos de vida, pensar no futuro; persuasão; profissão, realizar projetos e sucesso profissional, foram termos encontrados em menor número. O referido quadro traz as contagens por curso, tendo uma visão macro das inferências. Já o quadro a seguir traz a análise detalhada por curso entre os anos (alunos ingressantes e concluintes) para ilustrar cada bloco de números e onde as inferências foram identificadas.

\begin{tabular}{|c|c|c|c|c|c|c|c|}
\hline TERMOS & Inferências & Enf-1 & Ingressantes & Enf-2 & Ingressantes & Enf-3 & Ingressantes \\
\hline & & & Concluintes & & Concluintes & & Concluintes \\
\hline \multirow{2}{*}{ Em branco } & \multirow{2}{*}{61} & \multirow{2}{*}{14} & 8 & \multirow{2}{*}{36} & 29 & \multirow{2}{*}{11} & 6 \\
\hline & & & 6 & & 7 & & 5 \\
\hline \multirow{2}{*}{$\begin{array}{l}\text { Gerenciar um } \\
\text { negócio }\end{array}$} & \multirow{2}{*}{29} & \multirow{2}{*}{15} & 13 & \multirow{2}{*}{5} & 3 & \multirow{2}{*}{9} & 6 \\
\hline & & & 2 & & 2 & & 3 \\
\hline \multirow{2}{*}{ Inovação } & \multirow{2}{*}{57} & \multirow{2}{*}{36} & 23 & \multirow{2}{*}{13} & 6 & \multirow{2}{*}{8} & 8 \\
\hline & & & 13 & & 7 & & 0 \\
\hline \multirow{2}{*}{ Investimento } & \multirow{2}{*}{48} & \multirow{2}{*}{24} & 20 & \multirow{2}{*}{24} & 14 & \multirow{2}{*}{0} & 0 \\
\hline & & & 4 & & 10 & & 0 \\
\hline \multirow{2}{*}{ Persistência } & \multirow{2}{*}{25} & \multirow{2}{*}{9} & 8 & \multirow{2}{*}{12} & 9 & \multirow{2}{*}{4} & 2 \\
\hline & & & 1 & & 3 & & 2 \\
\hline \multirow{2}{*}{$\begin{array}{l}\text { Ter seu próprio } \\
\text { negócio }\end{array}$} & \multirow{2}{*}{129} & \multirow{2}{*}{52} & 36 & \multirow{2}{*}{56} & 39 & \multirow{2}{*}{21} & 15 \\
\hline & & & 18 & & 17 & & 6 \\
\hline
\end{tabular}

Quadro 46: Resultado da pesquisa qualitativa separados por curso e ano Fonte: Autora

A partir do quadro acima, são realizadas análises das inferências de maior relevância para o trabalho, buscando responder sua existência por meio das proposições teóricas que embasam o trabalho.

\subsubsection{Análise das Inferências}

O agrupamento dos termos "em branco" com 61 inferências e 15\% de presença, continham campos sem nenhum comentário, ou seja, em branco literalmente, como também continham respostas do tipo "não sei opinar", "não sei responder", "prefiro não opinar" e respostas inacabadas como "empreendedorismo é...". Tais tipos de respostas foram agrupadas como sendo "em branco" por não conterem nenhum conteúdo que pudesse ser possível análise de direcionar o entendimento para algum termo ou símbolo 
concreto. Cerca de $70 \%$ delas foram respondidas por alunos ingressantes dos três cursos pesquisados, como mostra o recorte do quadro com as inferências identificadas:

\begin{tabular}{|c|c|c|c|c|c|c|c|}
\hline TERMOS & Inferências & Enf-1 & Ingressantes & Enf-2 & Ingressantes & Enf-3 & Ingressantes \\
\hline & & & Concluintes & & Concluintes & & Concluintes \\
\hline \multirow{2}{*}{ Em branco } & \multirow{2}{*}{61} & \multirow{2}{*}{14} & 8 & \multirow{2}{*}{36} & 29 & \multirow{2}{*}{11} & 6 \\
\hline & & & 6 & & 7 & & 5 \\
\hline
\end{tabular}

Quadro 47: Resultado do termo "em branco"

Algumas reflexões podem ser ensaiadas nesta análise. Uma delas é que, por ser a última questão do instrumento de pesquisa, que continha outras 55 questões anteriores, todas assertivas, em que o respondente selecionava desde um discordo plenamente a um concordo totalmente, todas faziam menção ao tema empreendedorismo, traziam exemplos de ações caracterizadas como sendo do perfil empreendedor, Ainda assim, boa parte dos participantes da pesquisa, responderam em branco ou como descrito, e não foram capazes de opinar a respeito do tema. Pode-se também aferir que houve um desinteresse por parte dos respondentes em escrever a resposta, tendo em vista que todas as anteriores eram objetivas. Algo que causa estranheza é o fato de muitos responderem "não sei opinar" ou "empreendedorismo é..." sem completar a resposta, tendo em vista que haviam acabado de ler e responder questões que faziam menção à ações empreendedoras. Entretanto, mesmo assim, essas informações não foram suficientes para embasar o aluno a construir uma resposta a pergunta aberta, às vezes por estar desatento, no caso de ingressantes, mas um grande número de respondentes "em branco" foram dos anos concluintes, o que teoricamente já possuem um perfil mais comprometido e, portanto, tenderiam a levar mais a sério este tipo de pesquisa. Ainda, esses alunos concluintes estão na grande maioria, como apontou as matrizes curriculares dos três cursos, passando por trabalhos de conclusão de curso que em seu desenvolvimento, trabalham algum tipo de pesquisa, fato que poderia mostrar certo grau de comprometimento ou amadurecimento na participação da presente pesquisa.

O item agrupado "Gerenciar um negócio", com 29 inferências e 7\% de presença teve como respostas, argumentos que sinalizavam as operações do ato de administrar uma empresa como: planejamento empresarial, gerenciar operações, executar atividades, coordenar equipes e liderar pessoas. A teoria da administração, segundo Chiavenato (2006), compreende, em síntese, estas ações citadas nas respostas dos participantes representadas 
pelas quatro operações coordenadas da administração de empresas, que, executadas numa sequência gera um processo administrativo empresarial. As ações compreendem: planejar as ações por meio de escopo de processos; organizar os insumos dos quais serão necessários para a realização do plano; dirigir ou coordenar pessoas e times para a realização das tarefas pré-determinadas no plano e executar as operações mapeadas no plano. O processo todo compreende então: planejar, organizar, dirigir e executar, sendo essas as quatro etapas do ciclo administrativo de uma organização. Cerca de $80 \%$ delas foram respondidas por alunos ingressantes dos três cursos pesquisados, como mostra o recorte do quadro com as inferências identificadas:

\begin{tabular}{|c|c|c|c|c|c|c|c|}
\hline TERMOS & Inferências & Enf-1 & Ingressantes & Enf-2 & Ingressantes & Enf-3 & Ingressantes \\
\hline & & & Concluintes & & Concluintes & & Concluintes \\
\hline \multirow{2}{*}{$\begin{array}{l}\text { Gerenciar um } \\
\text { negócio }\end{array}$} & \multirow{2}{*}{29} & \multirow{2}{*}{15} & 13 & \multirow{2}{*}{5} & 3 & \multirow{2}{*}{9} & 6 \\
\hline & & & 2 & & 2 & & 3 \\
\hline
\end{tabular}

Quadro 48: Resultado do termo "gerenciar um negócio"

As respostas traziam frases que faziam menção a essas operações administrativas, sobretudo citações que envolviam a fase de planejamento administrativo. Alguns exemplos de respostas foram: "empreendedorismo é o ato de se administrar uma empresa e planejar as ações", "empreender é ter um bom planejamento financeiro", "empreendedorismo foca nas ações de planejar e controlar uma empresa", "empreendedorismo é a execução de tarefas de gestão"; "empreendedorismo é domínio na liderança e saber comandar pessoas para alcançar os objetivos"; "empreendedorismo é planejar uma empresa para o sucesso"; "empreendedorismo trata-se de um conjunto de ações do dia-a-dia de uma empresa organizada e bem administrada".

Ressalta-se que essas ações, indiretamente, fazem parte do cotidiano de um empreendedor. No entanto, são voltadas ao ato de administrar e não de empreender, sendo o ato de empreender, um ato estratégico, de visão, analítico enquanto o ato de administrar envolve ações, por isso tende a ser visto num nível tático e operacional.

O item agrupado "Inovação" com 57 inferências e 14\% de presença faz parte das características empreendedoras e é tido como a característica essencial para o êxito no ato de empreender. Schumpeter (1961) associa o empreendedorismo à inovação, ressaltando que ocorre por meio da criação de novos bens e serviços, colocando o empreendedor como um agente de mudanças, que contribui tanto para o crescimento quanto para o 
desenvolvimento econômico. Empreendedorismo, segundo ele, é o processo de criar algo novo com valor, dedicando o tempo e o esforço necessários, assumindo os riscos financeiros, psíquicos e sociais correspondentes e recebendo as consequentes recompensas da satisfação e independência econômica e pessoal. O termo inovação foi mais apontado pelos alunos do curso Enf-1, cerca de 70\% delas foram respondidas por alunos deste curso, como mostra o recorte do quadro com as inferências identificadas:

\begin{tabular}{|c|c|c|c|c|c|c|c|}
\hline TERMOS & Inferências & Enf-1 & Ingressantes & Enf-2 & Ingressantes & Enf-3 & Ingressantes \\
\hline & & & Concluintes & & Concluintes & & Concluintes \\
\hline \multirow{2}{*}{ Inovação } & \multirow{2}{*}{57} & \multirow{2}{*}{36} & 23 & \multirow{2}{*}{13} & 6 & \multirow{2}{*}{8} & 8 \\
\hline & & & 13 & & 7 & & 0 \\
\hline
\end{tabular}

Quadro 49: Resultado do termo "inovação"

Diferente do que pode parecer, inovação não é a mesma coisa que invenção. $A$ invenção está ligada a criação de um novo dispositivo, conceito ou serviço, que pode vir a ser útil. A capacidade inventora é aquele ato genial que cria a ideia. Já a inovação envolve um conceito mais amplo, em que a invenção faz parte apenas da primeira parte do processo. Assim, a inovação é a capacidade de transformar a invenção em um sucesso, ou seja, implementar a nova ideia (DRUCKER, 2016). Nesse sentido, este processo é inerente ao empreendedorismo.

A inovação, para Dornelas (2014), é o que impulsiona o empreendedorismo, em virtude das várias invenções que mudaram a forma de viver das pessoas. Invenções essas provenientes de algo nunca visto, ou da inovação de algo já existente e que foram criadas por pessoas que possuem características notáveis, que arriscam sem medo, têm uma visão do futuro, enxergam oportunidades onde ninguém mais enxergou.

O empreendedor, segundo Schumpeter (1961), é considerado o principal agente de inovações, sendo ele o responsável por buscar e conduzir projetos novos, correspondentes ao cerne da ação empreendedora. Para o autor, a vinculação de inovação e empreendedorismo refere-se a um método que ocorre nas suas mais diversas formas e meios. Assim, o empreendedor é o causador do forte impulso do capital, devido sua 'força destruidora e criativa' de novos mercados, serviços e produtos que carrega dentro de si. Schumpeter conceituou empreendedor como aquele que desafia ou destrói criativamente, referindo-se à expressão "destruição criativa" com forte mérito, estando subentendido que o empreendedor é considerado um ser criativo e é a força motora do capital. O processo de 
destruição fundamenta-se no princípio do desenvolvimento de novos produtos, novos métodos de trabalho e novos mercados, em síntese, trata-se de destruir o velho para se criar o novo.

Como explica Drucker (2016), as inovações podem ser classificadas em quatro abordagens: de produto, de processo, organizacional e de marketing. As inovações de produtos são desenvolvidas por meio de novas tecnologias e meios de produção, sendo maiores onde a economia é mais desenvolvida; inovações de processos têm por base as novas ideias referindo-se à adoção de métodos de produção novos ou aperfeiçoados; inovações organizacionais estão relacionadas às pessoas, culturas e rotinas de gestão; inovações de marketing referem-se à inovação de processo e métodos de manutenção e fidelização de marcas, ampliação de nicho de mercado e busca de novos segmentos. Todas as quatro abordagens podem ser trabalhadas sob o ponto de vista de ações empreendedoras.

De acordo com Oliveira et.al (2019), é possível identificar seis modelos de processo de inovações e que podem ser relacionadas ao empreendedorismo. O primeiro refere-se à inovação radical. Este tipo de inovação relaciona-se com o desenvolvimento de um conjunto de características, as quais originam um novo produto, sendo que as características finais do produto ou serviço podem não se alterar significativamente. O segundo modelo é a inovação de melhoria que envolve mudanças na qualidade de certos fragmentos das bases de característica do produto, sem modificar as demais bases. Refere-se também ao aperfeiçoamento do produto com melhorias nas características finais. A inovação incremental se refere à adição ou substituição de componentes existentes por outros inovadores, sendo um aperfeiçoamento das características finais do produto. O quarto modelo de inovação é a recombinação, que visa a dissociação ou a recombinação de vetores das características para formar um novo produto. O quinto modelo é a inovação por formalização que objetiva ordenar os atributos do produto, transformando-os em mais visíveis e padronizados. O sexto modelo de inovação é denominado adhoc, instituído a partir da construção conjunta entre o produtor/prestador do serviço e o cliente, resultante de uma solução apresentada para o problema identificado pelo cliente. 
Drucker (2016) defende a ideia de que a inovação para um empreendedor é condição sine qua non para o sucesso. Para o autor, não basta ter apenas viés inovador, é necessário um compromisso com a prática sistemática da inovação. "A inovação é função essencial ao espírito empreendedor e é por meio dela que o empreendedor cria novos recursos produtores de riqueza ou investe recursos existentes com maior potencial para criação de riqueza" (DRUCKER, 2016, p. 49). A inovação é tida como fator decisivo para vários outros autores:

- “O processo empreendedor está intrinsecamente relacionado com o fator inovador, quando este altera um produto ou serviço agregando valor a ele e transformando o modo de oferecer um produto, mudando seu ciclo de vida no mercado" (DORNELAS, 2014, pg. 79);

- “A prática empreendedora nos traz vários aspectos em mente, sobretudo o fator da inovação, característica fundamental no ato de empreender, por ser considerada um aspecto comportamental decisivo pelo fato de que tudo o que foi criado para revolucionar o estilo de vida das pessoas são frutos de uma revolução ou uma nova forma de utilizar coisas já existentes". Cabe lembrar que nada surge por acaso, por detrás de cada inovação temos pessoas capacitadas e com visão para isso. Estas têm a dádiva de além de perceber, arriscam, buscam algo novo, empreendem (DOLABELA, 2009, p. 112);

- O empreendedor tem como função reformular ou modificar um método ou maneira existente. Estes atores podem fazer isso de diversas formas, sendo por meio de uma grande inovação renovando os métodos ou simplesmente adicionando e/ou modificando minimamente a forma de trabalhar. "Nesse contexto, podemos considerar a inovação como elemento central do fenômeno do empreendedorismo, expressando-se em situações organizacionais, configuradas como oportunidades e transformações, que geram resultados positivos por meio da busca do novo" (SOUZA et.al, 2014, p. 41).

O item agrupado "Investimento" com 48 inferências e 12\% de presença e pode-se relacioná-lo com características que envolvem os conceitos da visão econômica e capitalista do empreendedorismo, pelo seu viés financeiro. Apenas os cursos Enf-1 e Enf-2 tiveram respostas com conteúdo voltado a este termo. O curso Enf-3 não obteve nenhuma resposta identificada, como pode ser observada no recorte do quadro a seguir: 


\begin{tabular}{|c|c|c|c|c|c|c|c|}
\hline TERMOS & Inferências & Enf-1 & Ingressantes & Enf-2 & Ingressantes & Enf-3 & Ingressantes \\
\hline & & & Concluintes & & Concluintes & & Concluintes \\
\hline \multirow{2}{*}{ Investimento } & \multirow{2}{*}{48} & \multirow{2}{*}{24} & 20 & \multirow{2}{*}{24} & 14 & \multirow{2}{*}{0} & 0 \\
\hline & & & 4 & & 10 & & 0 \\
\hline
\end{tabular}

Quadro 50: Resultado do termo "investimento"

As respostas que originaram o termo continham frases como "investir num negócio", "conseguir investir ou comprar uma empresa", "investir em um negócio que gere lucro", etc., o que sinaliza um pensamento voltado apenas à vertente financeira de se empreender.

A visão capitalista do empreendedorismo era denominada pelo termo "investidor de risco" e se referia a pessoa que reservava recursos financeiros a um negócio a partir de um montante de capital próprio para obter uma significativa taxa do retorno sobre aquele investimento (DRUCKER, 2016). Esta tendência de resposta aponta para o fato de que as pessoas ainda preservam aquela visão de homem de negócio, empreendedor, aquele que visava unicamente o lucro, tendo o investimento a única forma de ingressar no universo empreendedor. Para Zen e Fracasso (2008), a visão capitalista, mesmo com o passar dos anos e das novas nomenclaturas que o fenômeno do empreendedorismo ganhou, se mantém como válida e atual. Este equívoco está intimamente relacionado à visão do empreendedor enquanto empresário, dono do negócio e proprietário da empresa. Dessa forma, esse modo de pensar precisa ser trabalhado para que se amplie essa visão, trazendo à luz dos debates, outros aspectos tão importantes quanto o investimento para o sucesso empreendedor (MAIR e MARTí, 2004).

Para Austin et.al (2006), o caráter meramente financeiro atrelado ao empreendedorismo está alicerçado numa visão de mundo do homem moderno que mantém raízes meramente capitalistas. Segundo os autores, somos produtos do meio, cercado por questões que se destacam pela busca da competitividade, do ter em vez do ser, do status e da posição social das pessoas, relacionando isso ao êxito ou sucesso profissional. Tais ideologias não consideram fatores sociais e humanos, já introduzidos na história, mas que ficam às margens do que a sociedade ainda insiste em ter como padrão.

O item agrupado "Persistência" com 25 inferências e 6,2\% de presença pode ser relacionado com características que envolvem comportamentos individuais de busca de desafios, otimismo e vontade de vencer. A persistência, portanto, está enraizada na perspectiva do otimismo e da perseverança. 


\begin{tabular}{|c|c|c|c|c|c|c|c|}
\hline TERMOS & Inferências & Enf-1 & Ingressantes & Enf-2 & Ingressantes & Enf-3 & Ingressantes \\
\hline & & & Concluintes & & Concluintes & & Concluintes \\
\hline \multirow{2}{*}{ Persistência } & \multirow{2}{*}{25} & \multirow{2}{*}{9} & 8 & \multirow{2}{*}{12} & 9 & \multirow{2}{*}{4} & 2 \\
\hline & & & 1 & & 3 & & 2 \\
\hline
\end{tabular}

Quadro 51: Resultado do termo "persistência"

Pesquisas recentes comprovam que grande parte das novas empresas acabam por fechar em menos de cinco anos, não pela falta de qualidade, de investimentos ou de retorno do público, mas sim pela inexistência da capacidade de seguir adiante quando os acertos são menores que os erros, sendo sinal claro da falta de persistência de alguns dos empreendedores de nossa época (SEBRAE, 2017).

A persistência está direta ou indiretamente ligada a todo ecossistema que envolve o ato de empreender. $\mathrm{O}$ aprimoramento de ideias consiste em um ato de persistir, assim como o aprendizado, que também faz parte dessa dinâmica de repetições e insistência. A persistência é todo este conjunto motivacional de renovação de forças e esperanças naquilo que precisa estar determinado a realizar. Portanto, persistência, determinação, resiliência são essenciais para se galgar o sucesso.

Para David McClelland (1987) a persistência é um ato de agir diante de um desafio significativo repetidamente, tomando todas as ações necessárias para que o objetivo definido seja alcançado. No dicionário temos que persistir significa ser constante, perseverar, continuar, prosseguir e insistir. Por ser um atributo muito relacionado com expectativa, há de se ter parâmetros bastante reais para não superdimensionar ações, causando frustrações desnecessárias.

Por fazer parte de um conjunto de características inter-relacionadas, interdependentes, a existência de uma característica isolada não garante o sucesso. Persistência, sem planejamento adequado, sem comprometimento com metas, sem informações precisas, tende a fracassar, por mais insistência que se aplique (MARIONSANTOS E PAIXÃO, 2013).

Todos os casos de sucesso que são utilizados em eventos, workshops e treinamentos sobre empreendedorismo, tendem a focar na desconstrução da ideia de que somente ideias incríveis podem garantir o sucesso, já que os maiores exemplos do mercado corporativo, como Steve Jobs (Fundador e Ex-CEO da Apple), Bill Gates (Fundador e Ex-CEO da Microsoft), 
Jeff Bezos (Fundador e CEO da Amazon), Howard Schultz (Fundador da Starbucks), dentre tantos outros nomes fortes do mercado, são marcados pela persistência na busca pelo sucesso. Todos os citados, e também outros grandes nomes do empreendedorismo mundial, são exemplos de que nem sempre os resultados são obtidos de primeira. Em muitos casos, o sucesso só chegou depois de muitas tentativas e frustrações, mostrando que não é o acerto de primeira que marca o sucesso de um empreendedor, mas sim sua habilidade de lidar com os erros, tirar proveito dele e fazer com que sirvam como base para acertos futuros (MARION-SANTOS e PAIXÃO, 2013).

Persistir significa ter em mente que todos os problemas são resultados de atos, condutas e escolhas, mas que isso não significa que são permanentes ou imutáveis, sendo essencial que o empreendedor saiba aprender com seus erros, tendo em mente quais são seus pontos fortes e quais são as habilidades que precisam ser melhoradas para tornar-se um profissional ainda mais eficiente e bem-sucedido. O segredo do sucesso não está na crença de acreditar que não se deve errar, mas sim ter persistência em seguir adiante, humildade para aprender com os erros e fazer deles aprendizado para acertos futuros. A persistência não é a negação dos erros do passado, mas sim a maneira correta de aceitá-los e fazer deles base para seu sucesso (MINELLO, et.al, 2017).

O item agrupado "Ter seu próprio negócio", com 129 inferências e 32\% de presença, assim como o termo "investimento" discutido a pouco, trata de preposições antigas associadas ao termo empreendedorismo, que é frequentemente interpretado por expressões como "abrir seu próprio negócio", "ter uma empresa", "ser dono do seu próprio negócio", expressões que indicam a ideia de um empresário e não um empreendedor (Dornelas, 2013). Relatos antigos sobre o tema já demonstravam essa associação. A aparição do termo, registrada por Cantillon, relacionava-se ao ato de comprar algo por um preço e vendê-lo numa condição de incerteza, era sinônimo de empreendedorismo, convencionando-se que quem abre seu próprio negócio é um empreendedor (FILION, 1999).

No entanto, como explica Dornelas (2013), o empreendedorismo vai muito mais além de ter um negócio próprio. Trata-se de um conjunto de ações, atitudes, conhecimentos e postura voltados ao enfrentamento dos desafios de empreender. $O$ autor conclui que, nem todo empresário pode ser chamado de empreendedor e nem todo empreendedor precisa 
necessariamente ser um empresário, tendo em vista a existência de vários atores empreendedores que não abrem uma empresa e ainda assim são empreendedores, como o intra-empreendedor, o empreendedor social, o empreendedor digital, que podem empreender em projetos que não necessariamente abrir uma empresa.

\begin{tabular}{|c|c|c|c|c|c|c|c|}
\hline TERMOS & Inferências & Enf-1 & Ingressantes & Enf-2 & Ingressantes & Enf-3 & Ingressantes \\
\hline & & & Concluintes & & Concluintes & & Concluintes \\
\hline \multirow{2}{*}{$\begin{array}{l}\text { Ter seu próprio } \\
\text { negócio }\end{array}$} & \multirow{2}{*}{129} & \multirow{2}{*}{52} & 36 & \multirow{2}{*}{56} & 39 & \multirow{2}{*}{21} & 15 \\
\hline & & & 18 & & 17 & & 6 \\
\hline
\end{tabular}

Quadro 52: Resultado do termo "ter seu próprio negócio"

Qualquer um pode abrir uma empresa, mas somente um empreendedor será capaz de progredir com ele. Isso porque as ações que envolvem o cotidiano de um negócio requerem de seu dirigente uma postura dinâmica, sempre em busca pela inovação, seja de produtos, serviços ou mesmo processos. Necessita estar atento às mudanças de mercado, às exigências de seus consumidores e às variações que o segmento sofre (DRUCKER, 2016).

O gráfico a seguir sintetiza os termos resultantes desta pesquisa qualitativa e oportuniza uma visualização dos termos e sua incidência em cada curso e ano:

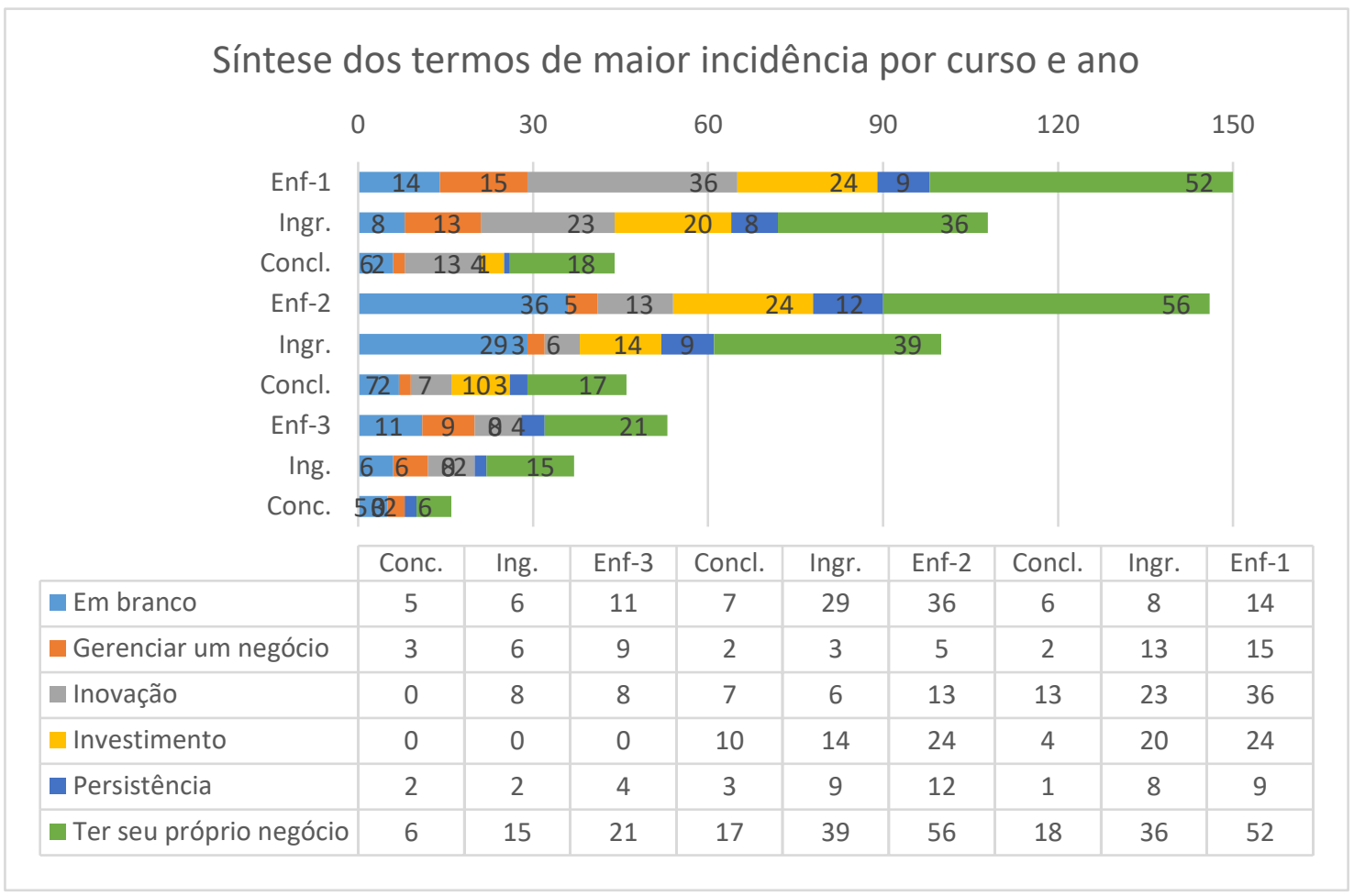

Gráfico 34: Síntese da pesquisa qualitativa separados por curso e ano Fonte: Autora 


\subsubsection{Nuvem de palavras}

A partir da identificação dos termos comuns de maior relevância e suas respectivas reflexões, pode-se aplicar a técnica de nuvem de palavras.

A técnica de nuvem de palavras é muito utilizada para criar esquemas visuais de alto impacto onde a mensagem é apresentada da forma mais objetiva possível. Pelo seu caráter prático, objetividade e clareza, os gráficos de nuvem de palavras são aplicados em vários setores, como na educação, em cursos de extensão, técnico ou mesmo graduação, em organizações voltadas a trabalhos de marketing e publicidade propaganda, setores de comunicação visual, jornalismo, entretenimento, etc.

Para a construção do gráfico de nuvem de palavras foi resgatado o quadro síntese dos termos da pesquisa qualitativa a seguir:

\begin{tabular}{|c|c|c|c|c|c|c|c|}
\hline TERMOS & Inferências & Enf-1 & Ingressantes & Enf-2 & Ingressantes & Enf-3 & Ingressantes \\
\hline & & & Concluintes & & Concluintes & & Concluintes \\
\hline \multirow{2}{*}{ Em branco } & \multirow{2}{*}{61} & \multirow{2}{*}{14} & 8 & \multirow{2}{*}{36} & 29 & \multirow{2}{*}{11} & 6 \\
\hline & & & 6 & & 7 & & 5 \\
\hline \multirow{2}{*}{$\begin{array}{l}\text { Gerenciar um } \\
\text { negócio }\end{array}$} & \multirow{2}{*}{29} & \multirow{2}{*}{15} & 13 & \multirow{2}{*}{5} & 3 & \multirow{2}{*}{9} & 6 \\
\hline & & & 2 & & 2 & & 3 \\
\hline \multirow{2}{*}{ Inovação } & \multirow{2}{*}{57} & \multirow{2}{*}{36} & 23 & \multirow{2}{*}{13} & 6 & \multirow{2}{*}{8} & 8 \\
\hline & & & 13 & & 7 & & 0 \\
\hline \multirow{2}{*}{ Investimento } & \multirow{2}{*}{48} & \multirow{2}{*}{24} & 20 & \multirow{2}{*}{24} & 14 & \multirow{2}{*}{0} & 0 \\
\hline & & & 4 & & 10 & & 0 \\
\hline \multirow{2}{*}{ Persistência } & \multirow{2}{*}{25} & \multirow{2}{*}{9} & 8 & \multirow{2}{*}{12} & 9 & \multirow{2}{*}{4} & 2 \\
\hline & & & 1 & & 3 & & 2 \\
\hline \multirow{2}{*}{$\begin{array}{l}\text { Ter seu próprio } \\
\text { negócio }\end{array}$} & \multirow{2}{*}{129} & \multirow{2}{*}{52} & 36 & \multirow{2}{*}{56} & 39 & \multirow{2}{*}{21} & 15 \\
\hline & & & 18 & & 17 & & 6 \\
\hline
\end{tabular}

Quadro 53: Resultado da pesquisa qualitativa separados por curso e ano Fonte: Autora

A nuvem de palavras anuncia termos de maior incidência a partir das análises quali. São termos como "gerenciar um negócio", "investimento", "persistência" e "inovação", cujos significados se entrelaçam no âmbito do empreendedorismo, com exceção do termo "em branco" que pode ter um significado negativo ou desconhecido, cabendo novas pesquisas no sentido de se investigar possíveis razões para este tipo de resposta. 
Ingressantes

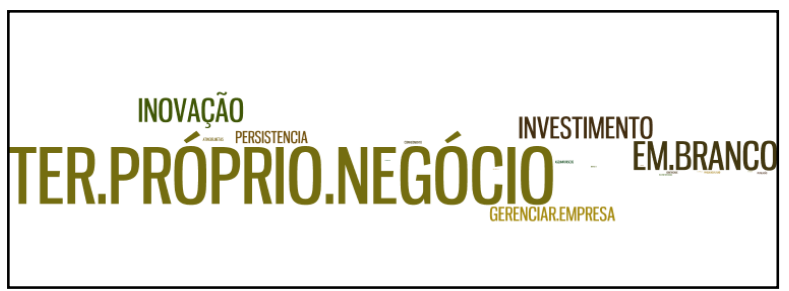

Concluintes

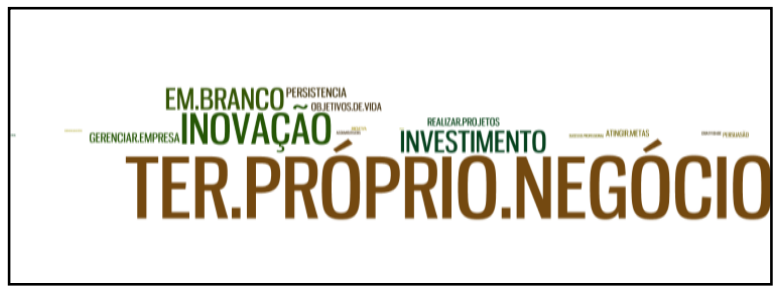

Ilustração 3: Nuvem de palavras considerando blocos de ingressantes e concluintes Fonte: autora

Os gráficos acima demonstram que não houve diferenças significativas das respostas entre alunos ingressantes e concluintes em relação às inferências mais relevantes. Observase que o termo "ter seu próprio negócio" foi o de maior destaque, o que significa que apresentou maior número. Depois dele pode-se observar os termos "em branco" também em destaque com um grau mais elevado no gráfico de ingressantes, como aponta o quadro numérico em que o termo "em branco" apareceu em maior número nas respostas dos ingressantes. Os termos "inovação" e "investimento" também aparecem em destaque, de modo bastante semelhante nos dois gráficos. Com isso pode-se concluir que os resultados entre os dois grupos de alunos se mantiveram muito próximos, ou, que os alunos que ingressam nos cursos ou os que saem têm a mesma percepção sobre o empreendedorismo.

\subsubsection{Considerações acerca da Pesquisa Qualitativa}

Os resultados desta pesquisa qualitativa, por meio da análise de conteúdo, de enunciação, serviram para identificar os termos identificados com a análise por categorização, especialmente as ideias que os participantes têm do termo empreendedorismo. Observou-se que os termos de maior incidência foram "em branco" e "ter próprio negócio". Tais termos podem indicar que o aluno, a exemplo da inferência "ter seu próprio negócio", a enxerga de um modo muito simplista e não possui domínio sobre o tema em termos das características do empreendedorismo contemporâneo como aspectos sociais, comportamentais, tecnológicos e interdisciplinares. Já o termo "em branco" pode ser interpretado considerando algumas situações como: aluno não se sentir confortável em responder, o que sinaliza ausência de conhecimento sobre o verdadeiro sentido da palavra empreendedorismo que vem a ser muito mais que ter um negócio, mas de possuir um conjunto de conhecimentos, habilidades e competências, sociais, humanas, administrativas, 
mercadológicas, econômicas que os colocam numa situação diferenciada dos demais profissionais e que lhes garantem uma vantagem em termos de diferenciação profissional, propensa a ajudar nos projetos os quais capitaneará. Outros termos como inovação, persistência e investimento fazem parte das características do empreendedor e mostram que o público pesquisado percebe essas características como importantes, porém, em menor intensidade.

$\mathrm{Na}$ pesquisa quali esperava-se que ao menos algumas respostas fossem mais detalhadas ou trouxessem maior riqueza dos atributos do empreendedor. O que se observou foram respostas curtas e objetivas, de cerca de 1 a 1,5 linha, apesar do espaço aproximado de sete linhas, e que sob o ponto de vista das características do empreendedor, não foram satisfatórias o suficiente, o que pode vir a ser uma janela de oportunidade para novas pesquisas que investiguem as razões deste comportamento discente, preferencialmente em termos longitudinais, do início ao término do curso com as mesmas turmas, para assim, poder acompanhar de modo mais efetivo possíveis avanços na aquisição das habilidades empreendedoras desses alunos.

\subsection{Triangulação dos Dados}

A triangulação foi realizada no intuito de relacionar os dados das abordagens qualitativa e quantitativa, buscando convergência com práticas pedagógicas voltadas ao ensino do empreendedorismo por meio de preposições teóricas. A pesquisa qualitativa contribuiu para identificar termos que correspondessem ao entendimento do participante em relação ao termo empreendedorismo. A pesquisa quantitativa contribuiu para comparar, por meio dos resultados estatísticos entre ingressantes e concluintes, quais características comportamentais empreendedoras puderam ser evidenciadas e em qual grau essas evidências foram percebidas e interpretadas.

O processo de triangulação desta pesquisa tem como objetivo auxiliar no entendimento das ações educativas voltadas ao ensino do empreendedorismo e à cultura empreendedora. Para isso, houve um resgate de dados da pesquisa qualitativa que servirá de matéria prima para as análises. O quadro a seguir foi o resultado das sínteses dos termos 
da análise qualitativa global, ingressantes e concluintes, tendo em vista, a equisimilhança entre eles pelos resultados quantitativos.

\begin{tabular}{|c|c|c|c|c|c|}
\hline TERMOS & Inferências & Enf-1 & Enf-2 & Enf-3 & Percentual \\
\hline Assumir riscos & 6 & 2 & 4 & 0 & \\
\hline Atingir metas & 9 & 7 & 0 & 2 & \\
\hline Conhecimento & 4 & 0 & 4 & 1 & \\
\hline Criatividade & 5 & 1 & 1 & 3 & \\
\hline Em branco & 61 & 14 & 36 & 11 & $15 \%$ \\
\hline Gerenciar um negócio & 29 & 15 & 5 & 9 & $7 \%$ \\
\hline Iniciativa & 4 & 1 & 2 & 1 & \\
\hline Inovação & 57 & 36 & 13 & 8 & $14 \%$ \\
\hline Investimento & 48 & 24 & 24 & 0 & $12 \%$ \\
\hline Objetivos de vida & 6 & 4 & 2 & 0 & \\
\hline Pensar no futuro & 4 & 1 & 2 & 1 & \\
\hline Persistência & 25 & 9 & 12 & 4 & $6,2 \%$ \\
\hline Persuasão & 4 & 2 & 3 & 0 & \\
\hline Profissão & 1 & 0 & 1 & 0 & \\
\hline Realizar projetos & 7 & 4 & 3 & 0 & \\
\hline Sucesso profissional & 4 & 1 & 1 & 2 & \\
\hline Ter seu próprio negócio & 129 & 52 & 56 & 21 & $32 \%$ \\
\hline TOTAL & 403 & & & & \\
\hline
\end{tabular}

Quadro 54: Resultado das Inferências da pesquisa qualitativa CCE's

Fonte: Autora

O quadro a seguir traz a síntese da pesquisa quantitativa:

\begin{tabular}{|l|c|c|c|}
\hline \multicolumn{1}{|c|}{ Características / Dimensões } & Média & $\begin{array}{c}\text { Desvio } \\
\text { Padrão }\end{array}$ & Mediana \\
\hline Busca de oportunidades e iniciativa & 17,46 & 3,35 & 18 \\
\hline Persistência & 16,34 & 2,86 & 16 \\
\hline Comprometimento & 17,97 & 3,52 & 18 \\
\hline Exigência de qualidade e eficiência & 19,08 & 3,05 & 19 \\
\hline Correr riscos calculados & 15,59 & 2,92 & 16 \\
\hline Estabelecimento de metas & 19,41 & 3,40 & 20 \\
\hline Busca de informações & 18,61 & 3,36 & 19 \\
\hline Planejamento e monitoramento sistemáticos & 17,16 & 2,96 & 17 \\
\hline Persuasão e redes de contato & 16,17 & 3,43 & 16 \\
\hline Independência e autoconfiança & 17,00 & 3,55 & 17 \\
\hline
\end{tabular}

Quadro 55: Análise Descritiva das CCE's de média, desvio padrão e mediana

Fonte: Autora

No intuito de analisar se as características empreendedoras mais bem pontuadas na pesquisa quantitativa fazem alguma relação com os termos de maior evidência na pesquisa qualitativa, foi elaborado o esquema a seguir, atendendo ao preceito de Zappellini e 
Feuerschüte (2015), de que triangulação deve utilizar um ponto de partida e confrontar os resultados obtidos com os diferentes métodos, populações, etc., bem como, com as conclusões obtidas com base na perspectiva originalmente adotada para conduzir as pesquisas anteriormente aplicadas. Trata-se, portanto, de verificar se o que está sendo observado e relatado possui o mesmo sentido em circunstâncias diferentes (AZEVEDO, et.al 2013).

\begin{tabular}{|c|c|c|c|}
\hline & \multirow[b]{2}{*}{ TERMOS } & \multirow[b]{2}{*}{$\begin{array}{c}\text { Inferênci } \\
\text { as }\end{array}$} \\
\hline Características / Dimensões & Média & & \\
\hline \multirow{2}{*}{$\begin{array}{l}\text { Busca de oportunidades e } \\
\text { iniciativa }\end{array}$} & \multirow{2}{*}{17,46} & Assumir riscos & 6 \\
\hline & & Atingir metas & 9 \\
\hline \multirow{2}{*}{ Persistência } & \multirow{2}{*}{16,34} & Conhecimento & 4 \\
\hline & & Criatividade & 5 \\
\hline Comprometimento & 17,97 & Em branco & 61 \\
\hline \multirow{2}{*}{$\begin{array}{l}\text { Exigência de qualidade e } \\
\text { eficiência }\end{array}$} & \multirow[b]{2}{*}{19,08} & Gerenciar um negócio & 29 \\
\hline & & Iniciativa & 4 \\
\hline \multirow{2}{*}{ Correr riscos calculados } & \multirow{2}{*}{15,59} & Inovação & 57 \\
\hline & & Investimento & 48 \\
\hline Estabelecimento de metas & \multirow{3}{*}{$\begin{array}{c}19,41 \\
18,61\end{array}$} & Objetivos de vida & 6 \\
\hline \multirow{2}{*}{ Busca de informações } & & Pensar no futuro & 4 \\
\hline & & Persistência & 25 \\
\hline \multirow{2}{*}{$\begin{array}{l}\text { Planejamento e monitoramento } \\
\text { sistemáticos }\end{array}$} & \multirow[t]{2}{*}{17,16} & Persuasão & 4 \\
\hline & & Profissão & 1 \\
\hline Persuasão e redes de contato & \multirow{3}{*}{$\begin{array}{c}16,17 \\
17,00\end{array}$} & Realizar projetos & 7 \\
\hline \multirow[t]{2}{*}{ Independência e autoconfiança } & & Sucesso profissional & 4 \\
\hline & & Ter seu próprio negócio & 129 \\
\hline
\end{tabular}

Quadro 56: Análise relacional das abordagens

Fonte: Autora

Pelo esquema acima pode-se aferir que todos os termos identificados na pesquisa qualitativa relacionam-se com as características comportamentais empreendedoras, em menor ou em maior grau. As correlações realizadas não esgotam as possibilidades, mesmo porque termos como "ter seu próprio negócio" e "gerenciar um negócio" estão ancorados de modo bastante intrínsecos a todas as características empreendedoras, tendo em vista que, para "tocar uma empresa" há de se ter perfil empreendedor num grau que lhe garanta sucesso na empreitada. De acordo com a literatura e pelas análises realizadas entre os resultados das pesquisas qualitativas e quantitativas, a tarefa de triangulação resultou numa convergência de resultados que, para Zappellini e Feuerschüte (2015), ocorre quando os resultados das 
pesquisas confirmam parcial ou totalmente uns aos outros. Também houve certo grau de complementaridade que, segundo os autores, ocorre quando os resultados do processo de correlação servem para ampliar o escopo das pesquisas quando analisadas isoladamente.

A partir dessas análises foi possível trazer conceitos e práticas na perspectiva da educação empreendedora e o que ela pode contribuir para avanços no ensino do empreendedorismo na graduação em saúde, contexto que o presente estudo ancora.

\subsubsection{Triangulação dos Dados com o Ensino do Empreendedorismo}

A literatura apresentada sobre o ensino do empreendedorismo, a educação empreendedora e a cultura empreendedora, sobretudo nas IES foi capaz de mostrar o quão favorável se torna a adoção de propostas educativas para sua aplicação.

A seguir, será apresentada uma síntese das características empreendedoras e possíveis ações educativas que possam ser implementadas para promover o processo de ensino.

A característica "busca de oportunidades e iniciativa", com média de 17,46 pontos, foi relacionada com os termos "assumir metas", "criatividade", "iniciativa" e "inovação". O ensino do empreendedorismo neste aspecto pode ser trabalhado como fator motivacional, promovendo atividades teórico-práticas que despertem no aluno o interesse no aprendizado. Isso porque tanto a característica quanto os termos relacionados a ela são aspectos comportamentais e que necessitam ser introduzidos num contexto educativo voltado à problematização, fazendo com que o estudante perceba a importância daquele aprendizado (ROCHA e FREITAS, 2014).

Diferente do ensino convencional - pautado na mera transmissão de conhecimento entre professor $x$ aluno onde o professor é o detentor do conhecimento e o aluno o receptor, na educação empreendedora, ensinar é algo além do que simplesmente transferir informações e conhecimentos (MELLO et.al, 2014). A teoria é abordada sob uma outra perspectiva, por meio da aplicação à realidade, privilegiando características do mercado, desafios, iscos e da economia locais. Tal aprendizagem deve combinar aulas teóricas em sala com atividades práticas, afim de proporcionar um impacto significativo e uma experiência enriquecedora aos estudantes (SILVA e PENA, 2017). 
A característica "persistência", com média de 16,34 pontos, foi relacionada com o termo "persistência". Trata-se de uma característica tida como essencial para o empreendedor. Para Henrique e Cunha (2006), um aspecto que está associado à persistência é a busca de informações. O conhecimento gerado deste acúmulo de informações processadas pode ser o motor propulsor do ato de insistir em algo, ou, da persistência.

Os autores enfatizam ainda, que a autonomia dos alunos em buscar soluções gera envolvimento coletivo em sala de aula, bem como na sua preparação para a realidade da prática profissional, em que os discentes demandam por atividades práticas, trabalhos em grupo, visitas técnicas, estágios e metodologias diferenciadas.

Para Dolabela (2008), a essência da estratégia didática da educação empreendedora para se trabalhar esse envolvimento do aluno está no "poder sonhar" e no "buscar realizar o sonho" e insistir no seu próprio projeto.

A característica "Comprometimento", com média de 17,97 pontos, foi relacionada com os termos "atingir metas" e "profissão". Trata-se de uma característica essencialmente motivacional, sendo uma condição sine qua non para todas as demais características. Existe uma interdependência muito forte entre as características comportamentais empreendedoras de modo que a ausência de uma pode comprometer o sucesso de outra, no entanto, a característica comprometimento está num patamar acima por ser considerada mola mestra para preparar o terreno para se trabalhar as demais (ROCHA e FREITAS, 2014). Comprometimento, segundo os autores, é motivação, que é motivo para a ação, que por sua vez deve estar enraizada na esfera do querer e do fazer

Para Lopes (2010), poucas áreas ligadas à educação exigem tanta reflexão sobre as atividades de implementação e orientação à ação do que a educação empreendedora. $O$ uso de metodologias de ensino que permitam o "aprender fazendo", a fim de que o aluno se depare com eventos críticos que o forcem a pensar de maneira diferente, buscando saídas e alternativas, ou seja, aprendendo com experiência, aprendendo com o processo. A autora resgata ainda propostas de aprendizagem orientadas para a ação como: aprendizagem experiencial; aprendizagem pela ação; aprendizagem contextual (processo de construir o significado a partir da interação social e da experiência); aprendizagem cooperativa (trabalhar em grupos heterogêneos exercitando a liderança, a comunicação, a coesão de equipe etc.) e 
aprendizagem centrada em problemas, ou problematização, em que o aluno é inserido no cerne da decisão (PADOVANI e CORRÊA, 2017).

A característica "Exigência de qualidade e eficiência" com média de 19,08 pontos, foi relacionada com os termos "criatividade" e "realizar projetos". Trata-se de uma característica em evidência no mundo dos negócios atualmente e que deve ser trabalhada de dentro pra fora buscando a conscientização do aluno para sua importância e não algo meramente mecânico e operacional. O fator de competitividade, por trás desta característica, sempre foi uma preocupação para uma boa gestão, mas encontra-se muito mais acirrada nos dias de hoje. Trabalhar questões de qualidade e eficiência requer disposição e a inclinação para fazer sempre mais e melhor. Um empreendedor com essa característica consegue inovar continuamente suas ações, satisfaz e excede as expectativas dos que acreditam nele e cria procedimentos para cumprir prazos e padrões de qualidade. A comunicação torna-se a ferramenta estratégica para este aprendizado.

A sala de aula se transforma assim em um ambiente em que os estudantes geram os conhecimentos que necessitarão para empreender, diferentemente do ensino convencional, em que o conhecimento é transmitido pelo professor. Cabe ao professor, nesse processo, formular perguntas, pois as respostas constituem o centro da tarefa empreendedora e serão construídas pelos alunos (MELLO et.al, 2014).

A característica "Correr riscos calculados", com média de 15,59 pontos, foi relacionada com o termo "investimento". Trata-se de uma característica que pode ser desenvolvida com atividades que coloquem o estudante em situações de decisão, em que possa avaliar e decidir por alternativas que desenvolver poder de decisão, autocontrole, dinamismo e trabalhar sob pressão. Para Santa Rita et.al (2008), atividades que possibilitam articulações entre conhecimentos teóricos e aqueles usados nas situações práticas contribuem para diminuir a distância entre os conhecimentos científicos e aqueles utilizados na solução de problemas da prática. Diante disso, entende-se que o conhecimento prático pode levar o aluno a uma situação mais segura, remetendo a situações de menor risco, possibilitando aos alunos agirem de forma mais confiante. Para Santos et.al (2014), a palavra risco deve ser apresentada o mais cedo possível, pois está presente na vida desde que nascemos e faz parte de nossas decisões, 
desde as mais simples até as mais complexas. Saber identificar e ter ações para minimizar ou evitar os riscos é motivo de planejamento.

A característica "Estabelecimento de metas", com média de 19,41 pontos, foi relacionada com os termos "atingir meta" e "pensar no futuro". Trata-se de característica que obteve uma pontuação diferenciada comparando com as demais. Um indivíduo com esta característica procura definir metas de longo prazo, claras e específicas e continuamente define e revisa os objetivos de curto prazo. O estabelecimento de metas está relacionado com inúmeras ações do indivíduo e acredita-se que por esta razão, esteve de modo mais presente nas pontuações das características. Além disso, o termo meta, objetivo e tarefa são comuns em muitas ações do nosso cotidiano e por isso já faz parte da rotina do aluno de modo que ele compreenda, de modo amplo, seu significado e importância.

Para Santa Rita et.al (2008), ações educativas que possam favorecer o desenvolvimento desta característica estão inseridas nos prazos de entrega de trabalhos, atenção às datas de calendário pedagógico, avaliações, etc., ações que reforçam a importância de prazos dessas metas de estudo.

A característica "Busca de informações", com média de 18,61 pontos, foi relacionada com os termos "conhecimento", "inovação" e "sucesso profissional”. Para Santos et.al (2014), tal característica vem de encontro com uma inquietação social do mundo moderno. Relacionase à busca por um modelo de inovação, incentivo à mudança e evolução, de estar em constante desenvolvimento, os diferentes contextos e entender o que desencadeia os problemas sociais. As universidades são constantemente influenciadas por jovens que estão causando transformações e com isso desenvolvem sua autonomia, principalmente por meio do convívio com amigos, profissionais, professores, pessoas inspiradoras, críticas e realizadoras, e do convívio com organizações e instituições que fomentam esta nova cultura do compartilhar, inovar e empreender. O principal fator das universidades acompanharem esta transformação é de fato a autonomia. Esta é a palavra-chave, como já afirmava Paulo Freire, na obra Pedagogia da Autonomia, que não há libertação que se faça com homens e mulheres passivos, sendo necessária conscientização e intervenção no mundo. A autonomia, além da liberdade de pensar por si, além da capacidade de guiar-se por princípios que 
concordem com a própria razão, envolve a capacidade de realizar, o que exige um homem consciente e ativo. Por isso, o homem passivo é contrário ao homem autônomo.

Esta busca ainda não é acessível a toda a população, e nem a maioria, em razão da educação, ideologia, cultura atuais ainda serem inversas a este novo formato, porém mais do que nunca esse número cresce, principalmente por meio dos acessos e redes a que estamos conectados. Afinal, à medida que passam os anos e as tecnologias são popularizadas, barateadas e disseminadas, mais as pessoas têm acesso a novas formas de mobilização, locomoção, eletricidade, educação, cursos, conteúdos, horas livres, pluralização de informações, dentre outros acessos que aumentam consequentemente suas perspectivas e oportunidades disponíveis.

A característica "Planejamento e monitoramento sistemáticos", com média de 17,16 pontos, foi relacionada com os termos "atingir metas", "gerenciar um negócio" e "ter seu próprio negócio". Em termos didáticos, Krüger (2019) destaca que, quando o aluno possui esta característica, seu comportamento inclina-se a dividir tarefas de grande porte em subtarefas com prazos definidos, tem de forma clara os prazos para cada etapa e consegue mapear essas atividades num escopo mental muito bem definido. Também possui a atitude de revisar os planos, observando as diversas variáveis que possam influenciar, ou ainda fazendo o uso de registros para a tomada de decisões (LOPES, 2010).

A característica "Persuasão e redes de contato", com média de 16,17 pontos, foi relacionada com os termos "persistência" e "persuasão". O comportamento presente em um estudante que apresenta características de persuasão e redes de contanto, para Santos et.al (2014) é o de discutir estratégias antecipadamente para influenciar os pares e ter poder de articulação com pessoas chave para atingir objetivos propostos. Esta característica também está associada à demanda de conteúdos mais próximos da realidade prática em sala de aula. Quanto mais próximo da prática o aluno estiver, mais confiante em suas argumentações e mais propriedade sobre o assunto terá. Para Dolabela (2009), o desenvolvimento de habilidades sociais que envolvem persuasão baseia-se no amadurecimento do conhecimento que, uma vez consolidado, garante postura de propriedade de argumentação. A interação entre os próprios discentes e entre discente e docente abre espaços para que o aluno se sinta 
presente e participe ativamente, e a partir dessa interação o aprendizado ocorre (ROCHA e FREITAS, 2014).

A característica "Independência e autoconfiança", com média de 17,00 pontos, foi relacionada com os termos "iniciativa", "persistência" e "ter seu próprio negócio". As aplicações de atividades didáticas que se mostram favoráveis para o desenvolvimento da autoconfiança do graduando permitem a ele vivenciar ao máximo os conteúdos aplicados em sala de aula e culminam na formação do comportamento empreendedor (DOLABELA, 2013), estimulando esse discente a estar mais preparado para os desafios do mercado profissional.

A forma com que a escola é gerenciada favorece para a formação de profissionais passivos. Salvo raras exceções, a forma organizacional da escola ainda é mecanicista, acreditando que todos são iguais, e por isso deve-se ter o mesmo conteúdo, se comportar e responder da mesma forma, havendo meritocracia para uma única forma de inteligência e comportamento, ao valorizar e estimular o homogêneo e não a individualidade de cada um. Para entregar um modelo que seja realmente transformador, mais do que a entrega de um produto pronto, é necessária uma construção em conjunto com professor $x$ aluno, para assim fomentar o engajamento de todos para as soluções propostas e que estas sejam realmente transformadoras.

\subsubsection{Considerações sobre a etapa de triangulação}

Moreira et.al (2019) recomendam algumas práticas para a melhoria da qualidade da educação empreendedora, reforçando que o ensino do empreendedorismo deve ser pensado e projetado de modo interdisciplinar, transversal e deve contemplar a diversidade do ambiente acadêmico, com o estímulo começando desde a formação de professores, que conciliem a formação acadêmica com a experiência prática empreendedora, professores que sejam capazes de equilibrar a teoria e estimular a prática empreendedora dos estudantes. Nessa perspectiva, as instituições de ensino devem privilegiar o desenvolvimento de características comportamentais empreendedoras, independente do curso superior. Essas recomendações podem auxiliar na ampliação de atividades a serem utilizadas por instituições de ensino superior em suas diretrizes pedagógicas, políticas de fomento e iniciativas de melhoria da educação que temos para uma educação que precisamos. 
Neste sentido, a proposta de Paulo Freire baseia-se na educação libertadora, problematizadora, que não pode ser mais um mero ato de depositar, ou de narrar, ou de transferir, ou de transmitir conhecimentos e valores aos educandos, meros pacientes, como preconiza a educação 'bancária', mas um ato autônomo (FREIRE, 1996).

A pedagogia bancária, criticada por Paulo Freire (1996), por considerar o aluno um mero agente passivo do processo educacional, ainda prevalece em muitas instituições. Tal método não só limita a capacidade dos estudantes, como compromete sua vontade de estudar. Nessa concepção se coloca o processo de educação como mera transferência de conhecimento, de maneira unilateral e vertical, imposta de forma autoritária, reforçando a passividade do aluno. Muitas instituições ainda trabalham esse modelo vertical de transmissão de conhecimento, que pouco incentiva a troca, inovação e criticidade, seguindo um padrão de repetição de pacotes de conhecimento. Paulo Freire, ao criticar esse modelo, defende a ideia de educação libertadora, como sendo aquela em que ambos são educadores e educandos no processo de ensino e aprendizado, “desta maneira, o educador já não é o que apenas educa, mas o que, enquanto educa, é educado, em diálogo com o educando que, ao ser educado, também educa" (FREIRE, 1999, p. 39). A Educação Libertadora abre espaço para o diálogo, a comunicação, o levantamento de problemas, o questionamento e a reflexão sobre o estado atual das coisas, e acima de tudo, busca sua transformação. Ainda segundo o autor:

\footnotetext{
O que parece indiscutível é que, se pretendemos a libertação dos homens, não podemos começar por aliená-los ou mantê-los alienados. A libertação autêntica, que é a humanização em processo, não é uma coisa que se deposita nos homens. Não é uma palavra a mais, oca, mitificante. É práxis, que implica na ação e na reflexão sobre o mundo para transformá-lo (FREIRE, 1999, p.38).
}

Nesse sentido, o ensino deve estimular a inovação e a criatividade dos estudantes através de interações, reflexões e atividades em ação, nas quais desenvolvam habilidades analíticas, sociais, inovadoras e de liderança (FEIO e OLIVEIRA, 2015; TAVARES, 2003). O ensino precisa ser mais envolvente, no qual os estudantes devem aplicar os conceitos, resolver problemas e tomar decisões para situações da vida real, ao invés de simplesmente conviverem com as teorias em sala de aula. Logo, eles se tornariam os atores principais da aprendizagem, sendo capazes de definirem e gerenciarem uma empresa, bem como o próprio destino profissional independentemente (SILVA e PENA, 2017). 
Santos et.al (2014) apresentam no livro sobre educação empreendedora, um modelo baseado em três principais vetores: finanças, identificação do macro e microambiente e satisfação pessoal e social. Há ainda dois vetores secundários que correm em paralelo: o aprendizado de uma nova língua e a sociabilidade. Quando alinhadas desde cedo, cria a cognição, e partindo de bases psicológicas, é o principal pilar do futuro empreendedor. Quanto mais cedo se inicia, maiores são as chances de adaptação com o mundo. Quando a ciência experimental é assimilada, a ciência aplicada torna-se mais fácil de ser absorvida. 0 esquema recebe a seguinte proposta:

- Ensino de finanças, o uso adequado do dinheiro e os recursos econômicos devem estar em primeiro plano. Saber quanto custa. Saber que uma árvore, por mais que the seja oferecida gratuitamente a muda, teve e terá um custo, pelo menos da água que a regará, mesmo que advenha de recursos naturais, como a chuva. É o "valor das coisas", às vezes medido pela satisfação pessoal, que pode ou não ser "comprada", e ao redor, a satisfação pessoal e das pessoas. Notamos que sem querer começamos com o princípio da sustentabilidade desde cedo.

- A identificação de uma ideia, uma proposta, um sonho, ou um negócio, no macro e microambiente, talvez seja a parte mais delicada do aprendizado. Não há nenhuma carreira que especialize um educador que domine toda e qualquer possibilidade de negócio, contudo, ele deve saber interagir e construir uma relação de acordo com a realidade de cada um. O processo é minucioso e quase pessoal, e prevalece a experiência, o feeling.

- A satisfação pessoal e social. Pessoal pela própria necessidade de realização, de "ser empreendedor", e social pela conscientização e a importância para a sociedade de um empreendedor, de gerar riquezas e utilidade social. (SANTOS, et.al 2014).

Com isso percebe-se que o ensino do empreendedorismo deve seguir uma nova metodologia, diferente da utilizada no ensino tradicional e própria à formação empreendedora. Dolabela (2009) defende uma mudança radical frente aos métodos tradicionais de ensino, que tendem a se concentrar na transferência de conhecimento, buscando uma aprendizagem centrada em pensar de forma independente e proativa. Para explicitar as particularidades de cada proposta de ensino, Dolabela (2009) descreve as 
características da educação tradicional e da educação empreendedora, sintetizadas no quadro a seguir:

\begin{tabular}{|c|c|}
\hline Educação convencional & Educação empreendedora \\
\hline Ênfase no conteúdo, que é visto como meta & Ênfase no processo, aprender a aprender \\
\hline Conduzido e dominado pelo instrutor & Apropriação do aprendizado pelo participante \\
\hline O instrutor repassa o conhecimento & $\begin{array}{l}\text { O instrutor como facilitador e educando; participantes } \\
\text { geram conhecimento }\end{array}$ \\
\hline $\begin{array}{l}\text { Aquisição de informações "corretas" de uma vez } \\
\text { por todas }\end{array}$ & O que se sabe pode mudar \\
\hline Currículo e sessões fortemente programados & Sessões flexíveis e voltadas a necessidades \\
\hline Objetivos do ensino impostos & Objetivos do aprendizado negociados \\
\hline Prioridade para o desempenho & Prioridade para a autoimagem geradora do desempenho \\
\hline $\begin{array}{l}\text { Rejeição ao desenvolvimento de conjecturas e } \\
\text { pensamento divergente }\end{array}$ & $\begin{array}{l}\text { Conjecturas e pensamento divergente vistos como parte } \\
\text { do processo criativo }\end{array}$ \\
\hline $\begin{array}{l}\text { Ênfase no pensamento analítico e linear; parte } \\
\text { esquerda do cérebro }\end{array}$ & $\begin{array}{l}\text { Envolvimento de todo o cérebro; aumento da } \\
\text { racionalidade no lado esquerdo do cérebro por } \\
\text { estratégias holísticas, não-lineares, intuitivas; ênfase na } \\
\text { confluência e fusão dos dois processos }\end{array}$ \\
\hline Conhecimento teórico e abstrato & $\begin{array}{l}\text { Conhecimento teórico amplamente complementado por } \\
\text { experimentos na sala de aula e fora dela }\end{array}$ \\
\hline Resistência à influência da comunidade & Encorajamento à influência da comunidade \\
\hline $\begin{array}{l}\text { Ênfase no mundo exterior; experiência interior } \\
\text { considerada imprópria ao ambiente escolar }\end{array}$ & $\begin{array}{l}\text { Experiência interior é contexto para o aprendizado; } \\
\text { sentimentos incorporados à ação }\end{array}$ \\
\hline $\begin{array}{l}\text { Educação encarada como necessidade social } \\
\text { durante certo período de tempo, para firmar } \\
\text { habilidades mínimas para um determinado papel }\end{array}$ & $\begin{array}{l}\text { Educação vista como processo que dura toda a vida, } \\
\text { relacionado apenas tangencialmente com a escola }\end{array}$ \\
\hline Erros não aceitos & Erros como fonte de conhecimento \\
\hline O conhecimento é o elo entre aluno e professor & $\begin{array}{l}\text { Relacionamento humano entre professores e alunos é de } \\
\text { fundamental importância }\end{array}$ \\
\hline
\end{tabular}

Quadro 57: Diferenças entre educação convencional e educação empreendedora

Fonte: Dolabela (2009)

Dolabela (2009) explicita essa diferença entre a formação tradicional e a formação empreendedora, ao afirmar que a educação empreendedora compreende novas formas de aprendizado e novas formas de relacionamento. Para o autor, ser empreendedor não é apenas uma questão de acúmulo de conhecimentos, mas uma mudança de atitude proveniente do desenvolvimento de valores, atitudes, comportamentos, modos de percepção de si mesmo e visão de mundo voltados à capacidade de inovar, de correr riscos, de conviver com a incerteza e perseverar. 
A ação fundamental no processo de educação empreendedora tem como primeiro passo permitir que os alunos experimentem a realidade, para depois aprenderem conceitos. Essa experimentação da realidade pode ser conseguida com práticas de problematização em que o aluno é estimulado a vivenciar uma situação-problema e a partir dela buscar soluções por meio da teoria, como defende a pedagogia freiriana. Esta inversão dá sentido à essa busca e enriquece o processo de aprendizagem (PADOVANI e CORRÊA, 2017).

Reina e Santos (2017) destacam que o sujeito empreendedor deve ser preparado para a ação e que suas características e necessidades de formação exigem particularidades no sistema de ensino voltado à ação empreendedora. Os autores explicam que, em geral, a formação universitária transfere saberes, em especial o "saber fazer" (know-how), ao passo que a formação empreendedora deve buscar desenvolver o "saber ser" e o "saber agir", além do próprio "saber empreender", descrito por Delors. Essas diferenças e especificidades da educação empreendedora em relação à educação tradicional têm levado à criação de novas práticas e modelos pedagógicos que permitam o desenvolvimento de habilidades e competências próprias do empreendedor.

Politis (2005) conclui que grande parte da aprendizagem empreendedora é, por natureza, experiencial e se concretiza como um processo desenvolvido por meio de ações, em que os indivíduos adquirem, assimilam e organizam conhecimentos obtidos a partir de estruturas existentes, construindo uma aprendizagem que influencia a ação empreendedora. O autor explica que a aprendizagem por meio de experiências e vivências se trata de um processo complexo, impulsionado pelo comportamento do empreendedor, e que desempenha papel importante quando se procura compreender sua aprendizagem.

Santos et.al (2014) ressaltam que é preciso ter atenção com a qualidade do corpo docente, sendo o educador um elemento indispensável para a educação empreendedora, que está sumariamente relacionada com os resultados do ensino do empreendedorismo e na capacidade empreendedora da universidade e de seus acadêmicos, sendo esse profissional um formador de opinião e referência para seu corpo discente. O papel dos educadores precisa ser repensado, substituindo a abordagem disciplinar por uma visão transdisciplinar, que contribuiria para a formação de indivíduos mais críticos, contributivos e colaborativos. Dessa forma, os professores que possuem maior envolvimento são aqueles que irão transmitir essa 
capacidade e motivação em sala de aula, formando assim jovens comprometidos e autônomos.

\section{Considerações Finais}

Conclui-se por meio do presente estudo, que a educação empreendedora voltada para o desenvolvimento de potencialidades comportamentais é um caminho promissor para desenvolver o protagonismo dos alunos universitários. Por ser ainda um termo muito alicerçado no âmbito do mundo dos negócios, que aborda a dimensão capitalista, existe uma forte resistência por parte dos educadores em se dispor em trabalhar o conteúdo com os alunos. No entanto, viu-se que esta ideia apesar de consolidada, é um equívoco que necessita ser trabalhado, no sentido de se mudar a cultura meramente 'business' ao termo.

Viu-se também, que os alunos dos três cursos de enfermagem pesquisados podem ser considerados empreendedores por possuírem as características empreendedoras, porém, num nível abaixo do recomendável pela literatura. As médias das pontuações ficaram em patamares entre 15 e 20 pontos. Como o instrumento utilizado traz uma escala de pontuação máxima de 25 pontos, conclui-se que as pontuações obtidas pelas médias, tanto de ingressantes como de alunos concluintes, constam em sua maioria em níveis considerados muito baixo, baixo e mínimo satisfatório. Diante desta pontuação, recomenda-se buscar articular ações didático-pedagógicas que promovam a autonomia do discente para ações empreendedoras que resultem no protagonismo desse sujeito, no sentido de ações autônomas de sua parte.

Evidências trazidas neste trabalho, em forma de livros, artigos, dissertações e a própria pesquisa de campo, confirmam a ideia de que o empreendedorismo foi transformado em palavra de ordem. Tais evidências apregoam que não se pode mais pensar em preparar as novas gerações de jovens profissionais para um futuro de emprego formal e garantias trabalhistas, pois essa perspectiva estará em poucos anos, em extinção. O discurso atual e necessário é de que o trabalhador deve estar provido de novas competências e habilidades para que consiga adquirir conhecimentos que gerem valor. 
Diversos autores defendem a ideia de que o trabalhador precisa, portanto, descobrir e desenvolver suas características empreendedoras e buscar solução para os problemas que deparar. Para eles, quem tem "espírito empreendedor", tem as competências para vencer os desafios que terão pela frente. Essa postura, segundo os gurus do empreendedorismo, lhe permitirá tomar decisões assertivas, pois serão baseadas em conhecimento prévio, que Ihe garantirá um empoderamento atitudinal. O profissional empreendedor sabe-se timoneiro de seu próprio destino e capaz de controlar situações adversas, aproveitá-las, liderar equipe e, com persistência e motivação, sabe obter resultados.

As características pessoais de um empreendedor, incluindo a sua capacidade inovadora, experiência acumulada, o constante aprimoramento das habilidades para criar e gerenciar negócios, são a chave para alcançarem o sucesso, independente da área. As características comportamentais empreendedoras podem ajudar os indivíduos a enfrentar os desafios de empreender, assim como a inexistência delas, pode inviabilizar um projeto promissor. O comportamento do empreendedor, no papel de gestor do seu próprio negócio, evidencia-se também na sua capacidade de lidar com a adversidade. Nesses casos, o ensino do empreendedorismo pode ajudar a aprimorar tais características e habilidades de gestão, promovendo a aprendizagem empreendedora.

A literatura apresentada propõe a criação de ambientes ricos em diversidade de experiências, de possibilidades de exploração de recursos pessoais e dirigidos à ampliação de horizontes e de perspectivas, atividades que contribuem para o desenvolvimento da educação empreendedora na universidade e, por conseguinte, o aprimoramento das características e atitudes empreendedoras desse indivíduo. Com isso, a educação empreendedora é apontada como uma das formas mais eficazes de se criar um ambiente universitário que promova a cultura empreendedora e a formação de novos profissionais com perfil empreendedor. Tal fenômeno pode estimular o engajamento e a inovação de formas de pensar sobre a atividade empreendedora e sua influência nesse processo, proporcionando novas formas de criação e disseminação do conhecimento.

Desenvolver o comportamento empreendedor no aluno é capacitá-lo para a criação, condução e implementação do processo criativo proporcionando a oportunidade de elaborar novos planos de vida, de trabalho, de estudo, de negócios, transformando-se, deste modo, no 
ator responsável pelo seu desenvolvimento pessoal e profissional. Desta forma, a educação empreendedora pode ser entendida como um processo dinâmico de conscientização, associação e aplicação, que envolve transformar a experiência e o conhecimento em resultados concretos, aprendidos e praticados. Trata-se, portanto, desenvolvimento de conhecimento, comportamento e aprendizagem efetivo-emocional.

Logo, a educação empreendedora pode oportunizar ao estudante enxergar e avaliar determinada situação, assumindo uma posição proativa frente a ela, capacitando-o a elaborar e planejar formas e estratégias de interagir com aquilo que ele passou a perceber. Além disso, essa educação empreendedora auxilia na compreensão da realidade, no contexto profissional e estimula a reflexão sobre transformações e inovações, buscando ações planejadas e tecnicamente embasadas, além de promover a transformação positiva da sua realidade, nas esferas pessoal, econômica e social.

Esse resultado é possível, visto que essa abordagem abrange desde o aluno que opte em abrir um negócio próprio, mas também a todos os futuros profissionais das mais diferentes áreas, que desempenhem suas atividades e profissões - de modo individual ou dentro de organizações - com valores, atitudes e comportamentos empreendedores. Mesmo que não queiram ter um negócio próprio, os estudantes podem ser beneficiados em sua formação com o desenvolvimento de conhecimentos e habilidades propícias à atividade empreendedora. $\mathrm{A}$ premissa de que a educação não é apenas geradora de aprendizagem para se empreender, mas, sobretudo, para o pensamento criativo, a geração de inovações, senso crítico e estímulo à autoestima e responsabilidade faz com que seja vista como necessária nos cursos de ensino superior.

Nessa perspectiva, para se atingir os diferentes objetivos propostos pela educação empreendedora, necessita-se traçar um plano de ensino que se adapte a metodologia pedagógica ao contexto da aprendizagem esperada. Atividades de ensino práticas são as mais propensas para contribuir para o estímulo do comportamento empreendedor. Entre as opções pedagógicas citam-se: workshops, oficinas, projetos interdisciplinares e transversais, palestras com profissionais consagrados, visitas técnicas, estudos de caso dirigidos, brainstorming, simulações, jogos e projetos desenvolvidos em grupos. 
Como toda ação pedagógica é executada pelo educador, há de se voltar os olhos para esse corpo docente no sentido de criar um escopo de trabalho onde o professor seja este sujeito transformador. Por melhor que seja um projeto de educação inovadora, ele só será efetivamente exequível com o envolvimento, comprometimento e preparo do corpo docente. O professor é que precisa ser preparado para o ensino do empreendedorismo, para ser um verdadeiro multiplicador das ideias que permeiam o tema.

A universidade, portanto, ao se dispor a apostar na formação empreendedora, deve executá-la de forma integrada, interdisciplinar e transversal. O empreendedorismo não deve ser discutido em disciplinas isoladas ou apenas com conteúdo teórico. O empreendedorismo deve ser vivenciado com intensidade por todos os envolvidos e em todas as direções. $O$ professor deve levar para a sala de aula a temática de modo integrado às outras disciplinas, à instituição e à comunidade. Cabe também aos educadores, a responsabilidade de fazer com que os alunos sejam estimulados a pensar e agir com uma mentalidade proativa. A sala de aula, cada vez mais, deve se transformar em espaços democráticos de compartilhamento de conhecimento e experiências. O ensino do empreendedorismo para formar um cidadão compromissado, atualizado e diferenciado deve ser trabalhado com todo vigor que merece.

Como contribuição acadêmica, os resultados do presente estudo podem contribuir para novas pesquisas relacionadas ao conhecimento empreendedor e experiência prévia, diante de ações que envolvam a educação empreendedora, visto que aponta ligação entre o ensino do empreendedorismo e as habilidades desenvolvidas na educação superior. Além disso, os resultados também contribuem para o entendimento da ação empreendedora em indivíduos com conhecimento empreendedor e experiência prévia. Como contribuição prática, os resultados revelam possíveis direções para o estímulo do empreendedorismo, tendo em vista o consenso de que os empreendedores não são nascidos, mas desenvolvidos. Para isso, reforça-se a necessidade de incluir a educação empreendedora como pauta no ensino superior, sugerindo-a como obrigatória junto aos currículos dos diferentes cursos de graduação, para que seu conteúdo alcance o estudante por meio de inserções teóricas e experiências práticas, preparando-os para os desafios que irão enfrentar na profissão. 


\subsection{Limitações e entraves da pesquisa}

Algumas limitações e entraves da pesquisa merecem ser descritos. Como limitação da pesquisa ressalta-se que a pesquisa de campo envolveu apenas um curso de graduação na área da saúde, curso de enfermagem, de três instituições de ensino superior da região, o que sugere que novas pesquisas semelhantes sejam realizadas abarcando outros cursos da área da saúde, confrontando os dados e enriquecendo o tema empreendedorismo na saúde, tendo em vista uma ausência de estudos científicos. Vale destacar, também, que foi utilizado apenas um instrumento de pesquisa, um questionário desenvolvido pelo autor David McClelland. Novos estudos podem ser realizados com o uso de outros instrumentos de coleta de dados para servir de parâmetros de comparação com o presente estudo.

Quanto aos entraves da presente pesquisa, algumas dificuldades foram enfrentadas sobretudo na parte da pesquisa de campo junto aos alunos dos três cursos pesquisados. Aspectos burocráticos foram os mais complexos e morosos em termos de limitação para a operacionalização da aplicação da pesquisa junto aos alunos. Na instituição de núcleo 1, é determinado que projetos de pesquisa que envolvem alunos de graduação sejam submetidos à comissão de graduação, para apreciação e emissão de parecer, exigido pelo comitê de ética para submissão ao referido CEP. Esta etapa consumiu alguns meses para sua aprovação. Logo após a emissão deste documento de aprovação, o projeto foi submetido ao comitê de ética da instituição via plataforma Brasil, que também passa por apreciação de pareceristas institucionais para emissão de parecer. Essa etapa durou 3 meses e passou por 3 submissões com ajustes ao projeto. Quando de sua aprovação, foi então posto em prática a etapa de pesquisa de campo que, necessariamente, teria abordagem com os alunos dos cursos, ingressantes e concluintes. Para isso, foi necessário obter listas com nomes de alunos e seus respectivos anos e salas, conteúdos esses, extremamente difíceis de se conseguir, mesmo envolvendo docentes da instituição nas solicitações.

Além desses percalços, a pesquisa de campo com alunos concluintes envolvia visitas in loco onde os alunos estavam em atividades práticas como estágio, por exemplo. No entanto, para abordagem com os alunos dentro das dependências municipais de saúde, foi solicitado um procedimento específico dos centros de saúde, com submissão do projeto de pesquisa, junto a um comitê de ética da própria secretaria da saúde municipal, via protocolo no 
Poupatempo da cidade. O referido procedimento tinha um prazo de 30 dias úteis para retorno da análise (que não era garantia de que viria aprovado ou com pendências a alterar, para ser submetido novamente ao mesmo processo), o que inviabilizou sobremaneira a visita a essas unidades de saúde municipais. Os alunos em estágio nessas unidades, portanto, foram abordados individualmente em outras práticas ou na parte externa dessas unidades de saúde (entrada ou saída dos alunos, estacionamentos, etc.).

Em virtude desses entraves, optou-se por adicionar mais dois cursos de graduação em enfermagem, com alunos ingressantes e concluintes, para que a pesquisa ganhasse mais robustez e seus resultados pudessem de alguma forma, contribuir para os estudos do tema com alunos da área da saúde. Após tais ajustes, a pesquisa foi retomada, partindo de autorizações dos reitores para as respectivas abordagens com os alunos. As coordenações dos cursos também forneceram autorizações por escrito e com elas, pode-se alinhar com os docentes das disciplinas, melhor dia e horário para a pesquisa.

Além das limitações operacionais, a presente pesquisa restringiu-se a investigar apenas um curso da área da saúde, o de enfermagem, dentre todos os cursos de graduação do campi ao qual a pesquisadora tem vínculo. Com isso pode-se conferir a esta pesquisa um recorte da realidade sobre ensino do empreendedorismo na área da saúde. Diante disso, acredita-se que novas pesquisas envolvendo demais cursos da área da saúde sejam relevantes analisar para ampliar o entendimento do tema e abranger novas profissões. Além disso, a pesquisa contou com alunos ingressantes e concluintes de um mesmo ano, ou seja, de turmas diferentes, alunos distintos e não uma pesquisa longitudinal com os mesmos alunos desde o ingresso até sua conclusão, buscando acompanhar o desenvolvimento desses alunos quanto às habilidades empreendedoras no transcorrer do curso, o que pode servir de proposta de futuros estudos.

Este estudo contou com vários outros estudos e produções científicas voltadas ao mesmo objetivo, o de pesquisar o perfil empreendedor, o ensino do empreendedorismo, a educação empreendedora e os resultados dessas competências para o sucesso do profissional da saúde. Como resultado desses trabalhos, pode-se observar um avanço dos conhecimentos sobre empreendedorismo quando esta passa por conteúdos voltados à formação do empreendedor e que os resultados são favoráveis quando são aplicadas técnicas de ensino 
voltadas à ação, prática e problematização de situações que desenvolvam nos alunos comportamentos proativos, promovendo sua autonomia e mentalidade empreendedora. 


\section{REFERÊNCIAS BIBLIOGRÁFICAS}

Akaike, H. (1974). A NEW LOOK AT THE StATISTICAL MODEL IDENTIFICATION. IEEE Transactions on Automatic Control, 19: 716-723.

AMORIM, Djanine A. A PEDAGOGIA EMPREENDEDORA NA EDUCAÇÃO BRASILEIRA. Revista Multidisciplinary Scientific Journal. 2018. Disponível em: https://www.nucleodoconhecimento.com.br/pedagogia-empreendedora: maio/2019.

AUSTIN, James; STEVENSON, Howard; Wei-Skillern S. SOCIAL AND COMMERCIAL ENTREPRENEURSHIP: SAME, DIFFERENT, OR BOTH? Entrepreneurship Theory and Practice. V. 36, N. 1, p. 1-22, 2006. Disponível em: http://www.scielo.br/pdf/rausp/v47n3/03.pdf. Acesso: janeiro/2019.

AZEVEDO, Carlos E. F.; OLIVEIRA, Leonel G. L.; GONZALEZ, Rafael K.; ABDALLA, Márcio M. A ESTRATÉGIA DE TRIANGULAÇÃO: OBJETIVOS, POSSIBILIDADES, LIMITAÇÕES E PROXIMIDADES COM O PRAGMATISMO. IV Encontro de Ensino e Pesquisa em Administração e Contabilidade, Brasília - DF, 2013. Disponível em: http://www.anpad.org.br/admin/pdf/EnEPQ5.pdf. Acesso: junho/2019.

BAGGIO, Adelar F.; BAGGIO, Daniel K. EMPREENDEDORISMO: CONCEITOS E DEFINIÇÕES. Rev. de Empreendedorismo, Inovação e Tecnologia, 1: 25-38, 2014. Disponível em: https://seer.imed.edu.br/index.php/revistasi/article/612/522. Acesso em janeiro/2018.

BARDIN, L. Análise de Conteúdo. Ed. 70. Portugal: Lisboa, 1977.

BARLACK, Lisete. COMPORTAMENTO EMPREENDEDOR: UM ESTUDO EMPÍRICO BASEADO NO REFERENCIAL DE MCCLELLAND. 2014. Revista PUC. Disponível em: DOI: https://doi.org/10.20503/recape.v4i3.21837. Acesso: julho/2019.

BARON, Robert A.; SHANE, Scott A. EMPREENDEDORISMO: UMA VISÃO DO PROCESSO. São Paulo, Cengage Learning, 2013.

BATTISTI, Iara D. E.; BATTISTI, Gerson. MÉTODOS ESTATíSTICOS. Rio Grande do Sul: Ed. Unijuí, 2008. 
BAUR, Gustavo; CARDOSO, Murillo B.; SPIGER, Vinícius; AMANTE, Cláudio José. PERFIL EMPREENDEDOR DOS ESTUDANTES DE ODONTOLOGIA DA UNIVERSIDADE FEDERAL DE SANTA CATARINA. 2016 Revista ABENO. Disponível em: https://revabeno.emnuvens.com.br/revabeno/article /view/268/222. Acesso junho/2016.

BOTTONI, Andrea; RODRIGUES, Evandro; Vieira, Robson Paz. EMPREENDEDORISMO NO CAMPO DA SAÚDE NO BRASIL. 2019. Brazilian Journal of Development. DOI:10.34117/bjdv5n7-045. Acesso: agosto/2019.

CERVO, Amado Luiz; BERVIAN, Pedro A. (2002). METOdologIA CIENTífICA. 5ạ Ed. São Paulo: Ed. Prentice Hall.

CHIAVENATO, Idalberto. INTRODUÇÃO À TEORIA GERAL DA ADMINISTRAÇÃO: Uma visão abrangente da moderna administração das organizações. 8a. ed. Rio de Janeiro: Elsevier, 2006.

COAN, Marival. EDUCAÇÃO PARA O EMPREENDEDORISMO: IMPLICAÇÕES EPISTEMOLÓGICAS, POLÍTICAS E PRÁTICAS. 2011. Tese Doutorado - UFSC. Disponível em: https://repositorio.ufsc.br/bitstream/handle/123456789/94847/298002.pdf?sequence=1. Acesso em maio/2019.

COAN, Marival. EDUCAÇÃO PARA O EMPREENDEDORISMO COMO ESTRATÉGIA PARA FORMAR UM TRABALHADOR DE NOVO TIPO. Artigo IX ANPED SUL. 2012. Disponível em: http://www.ucs.br/etc/conferencias/index.php/anpedsul/9anpedsul/paper/viewFile/ 2780/214. Acesso em maio/2019.

COUTINHO, C. METODOLOGIA DE INVESTIGAÇÃO EM CIÊNCIAS SOCIAIS E HUMANAS: Teoria e Prática. Coimbra: Edições Almedina, 2011.

CUNHA, Robson M.; SOARES, Elisa L.; FONTANILLAS, Carlos N. AS VANTAGENS DE APRENDIZADO DO EMPREENDEDORISMO: UM ESTUDO DESDE O ENSINO DE BASE ATÉ O SUPERIOR. Revista Pensamento Contemporâneo em Administração, Rio de Janeiro-RJ. setdez, 2009. Disponível em: www.periodicos.uff.br/pca/article/download. Acesso: maio/2019. 
DELORS Jacques. EDUCAÇÃO UM TESOURO A DESCOBRIR. Relatório para a UNESCO da Comissão Internacional sobre Educação para o século XXI. São Paulo-SP. Ed. Cortez, 1999. Disponível em: http://dhnet.org.br/dados/relatorios/a_pdf. Acesso: março/2019.

DIRETRIZES CURRICULARES NACIONAIS - Parecer CNE/CES nำ1.210/2001, aprovado em 12 de setembro de 2001, e Parecer CNE/CES no 1.133/2001, aprovado em 7 de agosto de 2001. Disponível em: http://portal.mec.gov.br/mais-educacao/323-secretarias-112877938/ orgaos-vinculados-82187207/12991-diretrizes-curriculares-cursos-de-graduacao acesso em abril/2017.

DOLABELA, Fernando. OFICINA DO EMPREENDEDOR - A metodologia que ajuda a transformar conhecimento em riqueza. Rio de Janeiro: Ed. Sextante, 2008.

DOLABELA, Fernando. PEDAGOGIA EMPREENDEDORA: O ensino de empreendedorismo na educação básica, voltado para o desenvolvimento social e sustentável. São Paulo: Sextante, 2009.

DORNELAS, José C. A. EMPREENDEDORISMO PARA VISIONÁRIOS: Desenvolvendo negócios inovadores para um mundo em transformação. 1. ed. Rio de Janeiro. Empreende/LTC, 2013.

DORNELAS, José C. A. EMPREENDEDORISMO: Transformando ideias em negócios. 5. ed. Rio de Janeiro. Empreende/LTC, 2014.

DRUCKER, PETER F. INOVAÇÃO E ESPÍRITO EMPREENDEDOR: Práticas e princípios. São Paulo: Cengage Learning, 2016.

ECKERT, Alex; OLEA, Pelayo M.; DORION, Eric C. E.; MECCA, Marlei S.; ECKERT, Micheli. G. 0 PERFIL EMPREENDEDOR NA GRADUAÇÃO: UM ESTUDO COMPARATIVO ENTRE INGRESSANTES E CONCLUINTES. Revista Pensamento Contemporâneo em Administração, v. 7, n. 2, p. 61-76, 2013. Disponível em: http://www.spell.org.br/documentos/ver/30823/operfil-empreendedor-na-graduacao--um-estudo-comparativo-entre-ingressantes-econcluintes. Acesso abril/2019. 
EUFRASIO, Carla C.; GOMES, Fernanda S. (2012). AS COMPETÊNCIAS E CARACTERÍSTICAS QUE INFLUENCIAM NO SUCESSO DO EMPREENDEDOR. Biblioteca Digital - FUNVIC. Disponível em: http://hdl.handle.net/123456789/448 - acesso abril/2017.

FEIO, Ana; OLIVEIRA, Clara Costa. (2015). CONFLUÊNCIAS E DIVERGÊNCIAS CONCEITUAIS EM EDUCAÇÃO EM SAÚDE. Saúde Soc. São Paulo, v.24, n.2, p.703-715, 2015. Disponível em: http://www.scielo.br/pdf/sausoc/v24n2/0104-1290-sausoc-24-02-00703.pdf. Acesso maio/2017

FERNANDES, Josicélia Dumêt; et all. (2005). DIRETRIZES CURRICULARES E ESTRATÉGIAS PARA IMPLANTAÇÃO DE UMA NOVA PROPOSTA PEDAGÓGICA; Estudo teórico, Revista Escola de Enfermagem USP, pg 443-449; (2005). Disponível em: http://www.scielo.br/pdf/reeusp/v39n4/10, acesso em abril/2017.

FERNANDES, Nicole M. O ENSINO DO EMPREENDEDORISMO: UM ESTUDO DE CASO NAS ÁREAS DA SAÚDE, EXATAS E HUMANAS EM INSTITUIÇÕES DE ENSINO SUPERIOR DO INTERIOR PAULISTA. Dissertação de Mestrado, Universidade de Ribeirão Preto. 2014.

FERREIRA, Paulo Gitirama Gomes; MATTOS, Pedro Lincoln Carneiro Leão. EMPREENDEDORISMO E PRÁTICAS DIDÁTICAS NOS CURSOS DE GRADUAÇÃO EM ADMINISTRAÇÃO: OS ESTUDANTES LEVANTAM O PROBLEMA. Gepec - UFPE (2010). Disponível em: https://www.ufpe.br/gepec/exemplos/07_artigo02.pdf. Acesso em maio/2017

FILLION, Louis Jacques. EMPREENDEDORISMO: EMPREENDEDORES E PROPRIETÁRIOSGERENTES DE PEQUENOS NEGócIOS. RAUSP - Revista de Administração, São Paulo, v. 34, n.2, p. 05-28, abr./jun. (1999). Disponível em: http://200.232.30.99/busca/artigo.asp?num_ artigo=102. Acesso: maio/2017.

FONSECA, Giovani C.; MUYLDER, Cristiana F. AUTO-PERCEPÇÃO DO PERFIL MCCLELLAND: UM ESTUDO DE CASO EMPRETEC MANHUAÇU. Revista Ciências Sociais em Perspectiva, Vol. 9 - № 16. 2010. Disponível em: http://e-revista.unioeste.br/index.php/_ccsaemperspectiva/ article/download/2376/3285. Acesso: julho/2019. 
FLORENCIO, LUTEMBERG DE ARAÚJO (2010) ENGENHARIA DE AVALIAÇÕES COM BASE EM MODELOS GAMLSS, Dissertação - Mestrado, Universidade Federal de Pernambuco. CCEN, Estatística, 2010.

FREIRE, Paulo. PEDAGOgIA dA AUTONOMIA: SABERES NECESSÁRIOS À PRÁtiCA EDUCATIVA. São Paulo: Paz e Terra, 1996.

FREIRE, Paulo. A EDUCAÇÃo COMO PRÁtICA DA LIBERDADE. 23. ed. Rio de Janeiro: Paz e Terra, 1999.

FRIEDLAENDER, GILDA MARIA S. METODOLOGIA DE ENSINO-APRENDIZAGEM VISANDO O COMPORTAMENTO EMPREENDEDOR. Tese Doutorado. UFSC, Florianópolis-SC. 2004. Disponível: http://dainf.utfpr.edu.br/Downloads/TeseDoutorado.pdf. Acesso: abril/2019.

GIL, Antonio Carlos (2002). COMO ELABORAR PROJETOS DE PESQUISA. 4ạ Ed. São Paulo: Ed. Atlas.

HAIR Jr., Joseph F.; BABIN, Barry; SAMOUEL, Philip; MONEY, Arthur. FUNDAMENTOS DE MÉTODOS DE PESQUISA EM ADMINISTRAÇÃO. Porto Alegre: Bookman, 2005.

HAIR JR., Joseph F.; BLACK, William C.; BABIN, Barry J.; ANDERSON, Rolph E.; TATHAM, Ronald L.; SANT'ANNA, Maria Ap. G. A. S. ANÁLISE MULTIVARIADA DE DADOS. 6a ed., A. Sant'Anna, Trad. Porto Alegre, RS: Bookman, 2009.

HARARI, Yuval N. HOMO DEUS: UMA BREVE HISTORIA DO AMANHÃ. Tradutor, Paulo Geiger. São Paulo: Ed. Cia das Letras, 2016.

HENRIQUE, Daniel Christian; CUNHA, Sieglinde Kindl; (2006). METODOLOGIAS, RECURSOS E PRÁTICAS DIDÁTICO-PEDAGÓGICAS NO ENSINO DE EMPREENDEDORISMO EM CURSOS DE GRADUAÇÃO E PÓS-GRADUAÇÃO NACIONAIS E INTERNACIONAIS. 30․ Encontro ANPAD, 2006. Salvador/BA. Disponível em: http://www.anpad.org.br/enanpad/2006/dwn/ enanpad2006-gctc-1212.pdf. Acesso abril/2017

HISRICH, Robert D. EMPREENDEDORISMO. 5.ed. Porto Alegre: Bookman, 2004.

IBGE - Instituto Brasileiro de Geografia e Estatística. INDICADORES SOCIODEMOGRÁFICOS E DE SAÚDE NO BRASIL. Disponível: www.ibge.gov.br. Acesso: maio/2019 
ITELVINO, Lucimar S.; COSTA, Priscila R.; GOHN, Maria da Gloria M.; RAMACCIOTTI, Claudio; PORTO, Geciane S. FORMAÇÃO EMPREENDEDORA PARA GERAÇÃO DE INOVAÇÕES SOCIAIS. Revista Gestão e Regionalidade v.34, 2018. Disponível em: doi: 10.13037/gr.vol34n101.4172. Acesso junho/2019.

KATZ, Jerome. A. THE CHRONOLOGY AND INTELLECTUAL TRAJECTORY OF AMERICAN ENTREPRENEURSHIP EDUCATION: 1876-1999. Journal of Business Venturing. v. 18, 2003. Disponível em: http://citeseerx.ist.psu.edu/viewdoc/download?doi=10.1.1.469.7583\&rep= rep1\&type=pdf. Acesso: novembro/2018.

KAUR, Hardeep; BAINS, Anupama. UNDERSTANDING THE CONCEPT OF ENTREPRENEUR COMPETENCY. Journal of Business Management \& Social Sciences Research (JBM\&SSR) V.11 2013. Disponível em: http://citeseerx.ist.psu.edu/viewdoc/download?doi=10.1.1.403.3169 \&rep=rep1\&type=pdf. Acesso: agosto/2019.

KRÜGER, Cristiane. EDUCAÇÃO EMPREENDEDORA: CARACTERÍSTICAS ATITUDES DE DISCENTES E DOCENTES. Dissertação de Mestrado - Universidade Federal de Santa Maria, Santa Maria-RS. 2016.

KRÜGER, Cristiane.; PINHEIRO, J. P.; Fernando MINELLO, I. F. (2017): AS CARACTERÍSTICAS COMPORTAMENTAIS EMPREENDEDORAS DE DAVID MCCLELLAND, Revista Caribeña de Ciencias Sociales (2017). Disp.: http://www.eumed.net/rev/caribe/2017/mcclelland.html

KRÜGER, Cristiane; BÜRGER, Rafaela E.; MICELLO, Ítalo F. O PAPEL MODERADOR DA EDUCAÇÃO EMPREENDEDORA DIANTE DA INTENÇÃO EMPREENDEDORA. 2019. E\&G Economia e Gestão, Belo Horizonte, v. 19, n. 52, Jan./Abr. 2019. Disponível em: http://200.229.32.55/index.php/economiaegestao/article/view/18224/14852. Acesso: junho/2019.

KUHN, Thomas. A ESTRUTURA DAS REVOLUÇõES CIENTíFICAS. 5. ed. São Paulo: Perspectiva, 1998.

KURATKO, Donald F. ENTREPRENEURIAL LEADERSHIP IN THE 21ST CENTURY. Journal of Leadership and Organizational Studies, 2007, Vol. 13, No. 4. Disponível em: 
https://pdfs.semanticscholar.org/bb70/69e380e3105ba33f36a2ef51bb53e530dc5e.pdf. Acesso: julho/2018.

LEAL, Antonio F. APRENDER A EMPREENDER: UM PILAR NA EDUCAÇÃO DE JOVENS E ADULTOS - A EXPERIÊNCIA DO SEBRAE. Dissertação de Mestrado. Curso Programa de Pósgraduação em Educação. UFP, João Pessoa/Paraíba, 2009. Disponível em: https://repositorio.ufpb.br/jspui/bitstream/tede/4851/1/arquivototal.pdf. Acesso: junho/2019.

LETTIERI, Flávio. EMPREENDEDORISMO NA EDUCAÇÃO: MODISMO OU NECESSIDADE. Revista Direcional Escolas, 2010. Disponível: www.sommaonline.com.br/direcionalescolas. Acesso em: julho/2019.

LÉVESQUE, Benoit. EMPREENDEDOR COLETIVO E ECONOMIA SOCIAL: OUTRA FORMA DE EMPREENDER. Revista Virtual de Gestão de Iniciativas Sociais, v. 1, p. 44-64, out. 2004

LÉVY, Pierry. AS TECNOLOGIAS DA INTELIGÊNCIA. 2. ed. São Paulo: Editora 34, 2010.

LIBÂNEO, J. C.; OLIVEIRA, J. F. (1998). A EDUCAÇÃO ESCOLAR: SOCIEDADE CONTEMPORÂNEA. In: Revista Fragmentos de Cultura, v. 8, n.3, p.597-612, Goiânia: Ed. IFITEG.

LIMA, Edmilson; HASHIMOTO, Marcos; MELHADO, João; ROCHA, Ricardo. CAMINHOS PARA UMA MELHOR EDUCAÇÃO SUPERIOR EM EMPREENDEDORISMO NO BRASIL. XXXVIII Encontro ANPAD, Rio de Janeiro-RJ. 2014. Disponível em: http://www.anpad.org.br/admin/ pdf/enanpad/2014_ESO1960.pdf Acesso: maio/2019.

LOPES, C. L. J. EDUCAÇÃO EMPREENDEDORA: UM ESTUDO DO PROJETO DE EMPREENDEDORISMO 10.0 APLICADO AOS ALUNOS DO CURSO TÉCNICO EM INFORMÁTICA. Revista de Empreendedorismo, inovação e tecnologia, 1(1)39-44, 2014.

LOPES, Rose Mary (org). EDUCAÇÃO EMPREENDEDORA: CONCEITOS, MODELOS E PRÁTICAS. 1a ed., Rio de Janeiro: Elsevier; São Paulo: Sebrae, 2010.

LUCENA, Rosivaldo L.; CENTURIÓN, Wanusa C. AS CONTRIBUIÇõES DA PEDAGOGIA FREIREANA AO DESENVOLVIMENTO DE PROFISSIONAIS EMPREENDEDORES NA ÁREA DE 
ADMINISTRAÇÃO. 2011. III Encontro de Ensino e Pesquisa em Administração e Contabilidade, João Pessoa/PB. Disponível em: http://www.anpad.org.br/admin/pdf/EnEPQ224.pdf. Acesso agosto/2019.

MAIR, Johana; MARTÍ, Ignasi (2004). SOCIAL ENTREPRENEURSHIP RESEARCH: A SOURCE OF EXPLANATION, PREDICTION, AND DELIGHT Journal of World Business, V. 41 - 36-44, 2006, Disponível em: https://doi.org/10.1016/j.jwb.2005.09.002. Acesso: abril/2019.

MANSFIELD, R. S.; MCCLELLAND, D. C.; SPENCER, J. L. M.; SANTIAGO, J. THE IDENTIFICATION AND ASSESSMENT OF COMPETENCIES AND OTHER PERSONAL CHARACTERISTICS OF ENTREPRENEURS IN DEVELOPING COUNTRIES. Final report. McBer and Company. Massachusetts, 1987.

MARCONI, Marina de Andrade; LAKATOS, Eva Maria. METODOLOGIA CIENTíFICA. 4ạ Ed. São Paulo: Ed. Atlas. 2004.

MARION-SANTOS, Ana Carolina; PAIXÃO, Marisa Regina. ESTUDO DO PERFIL EMPREENDEDOR DO ALUNO DE GRADUAÇÃO EM ADMINISTRAÇÃO EGRESSO DE INSTITUIÇÕES DE ENSINO DA REGIÃO DE JUNDIAÍ. REVISTA DE TECNOLOGIA APLICADA (RTA) Vol. 2, No. 1, Jan-Abr 2013, p.12-27 ISSN: 2237-3713. Disponível em: www.cc.faccamp.br/ojs-2.4.8-2/index.php/RTA/article/748/346. Acesso Abril/2018.

MATTHIENSEN, A. USO DO COEFICIENTE ALFA DE CRONBACH EM AVALIAÇÕES POR QUESTIONÁRIOS. EMBRAPA. Boa Vista, RR. 2011 https://ainfo.cnptia.embrapa.br/digital/ bitstream/item/68073/1/DOC-48-2011-ID-112.pdf. Acesso: julho/2019.

MAXIMIANO, A. C. A. INTRODUÇÃo À TEORIA GERAL DA ADMINISTRAÇÃO. 3. ed. São Paulo: Atlas, 2015.

MAXWELL, J. A. QUALITATIVE RESEARCH DESIGN: An interactive approach. Thousand Oaks: Sage, 1996.

MCCLELLAND, D. C. MANAGING MOTIVATION TO EXPAND HUMAN FREEDOM. American Psychologist, Washington, v. 33, n. 1. p. 201-210. 1987. 
MCCLELLAND, D. C. A SOCIEDADE COMPETITIVA: REALIZAÇÃO E PROGRESSO SOCIAL. Rio de Janeiro: Expressão e Cultura, 1972.

MCCLELLAND, D. C. THE ACHIEVEMENT SOCIETY. The Achieving Society. Princeton, NJ: Van Nostrand. 1961. Disponível em: http://dx.doi.org/10.1037/14359-000. Acesso: outubro/2018.

MELLO, Carolina de Castro Barbosa; ALVES, Renato Oliveira; LEMOS, Stela Maris Aguiar. METOdOLOGIAS DE ENSINO E FORMAÇÃO NA ÁREA DA SAÚDE: REVISÃO DE LITERATURA. Rev. CEFAC. (2014) Nov-Dez; 16(6):2015-2028. Disponível em: http://www.scielo.br/pdf/rcefac/v16n6/1982-0216-rcefac/pdf. Acesso: Maio/2017.

MINAYO, M. C. S. ANÁLISE QUALITATIVA: TEORIA, PASSOS E FIDEDIGNIDADE. Ciência e Saúde coletiva. v. 17, p. 621-626, 2012.

MINAYO, M. C. S. DESLANDES, S. F. GOMES, R. PESQUISA SOCIAL: Teoria, método e criatividade. 32. ed. Petrópolis: Vozes, 2012.

MINELLO, Ítalo F. RESILIÊNCIA E INSUCESSO EMPRESARIAL: o comportamento do empreendedor diante do fracasso nos negócios. Curitiba: Appris, 2014.

MINELLO, Ítalo F.; BÜRGER, Rafaela E.; KRÜGER, Cristiane. 2017. CARACTERÍSTICAS COMPORTAMENTAIS EMPREENDEDORAS: UM ESTUDO COM ACADÊMICOS DE ADMINISTRAÇÃO DE UMA UNIVERSIDADE BRASILEIRA. Rev. Adm. UFSM, Santa Maria, v. 10, p. 72-91, Ago- 2017. Disponível: DOI: 10.5902/19834659 24894. Acesso: janeiro/2019 MORAES, Roque. ANÁLISE DE CONTEÚDO. Revista Educação, Porto Alegre, v. 22, n. 37, p. 732, 1999. Disponível em: http://mgos.com.br/analiseconteudo.html. Acesso: janeiro/2018 MOREIRA, Marcia A.; SILVA, Silvio B.; SANTOS, Fábio L.; SANTIAGO, Ana M. A INSERÇÃO DA EDUCAÇÃO EMPREENDEDORA NOS CURSOS DE ADMINISTRAÇÃO EM INSTITUIÇÕES DE ENSINO SUPERIOR DA REGIÃO METROPOLITANA DE BELÉM - PA. Interfaces Científicas Humanas e Sociais • Aracaju • V.8 • N.1 • p. 87 - 102 • Abril/Maio/Junho - 2019. Disponível em: https://periodicos.set.edu.br/index/humanas/article/4331/3437. Acesso julho/2019. 
MORETTIN, Pedro A.; BUSSAB, Wilton O. ESTATístICA BÁSICA. 6ạ ed. São Paulo: Saraiva, 2010.

MOTA, Sônia Ap. S. DIAGNÓSTICO DA CAPACIDADE EMPREENDEDORA DE ESTUDANTES UNIVERSITÁRIOS E PROFISSIONAIS DE MICRO PEQUENAS E MÉDIAS EMPRESAS. Campo Limpo Paulista-SP: FACCAMP, 2013

MURARO, Renata. VERRUCK, Fabio. CRIAÇÃO DE INSTRUMENTO PARA AVALIAÇÃO DE PERFIL EMPREENDEDOR EM MEIO ACADÊMICO. XXXII ENCONTRO NACIONAL DE ENGENHARIA DE PRODUCAO. Bento Gonçalves, RS, Brasil, 2012. Acesso abril/2017 Disponível em: http://www.abepro.org.br/bib/enegep2012_TN_STO_166_964_20449.pdf.

NAKAO, Tymo. EMPREENDEDORISMO NA SAÚDE. 2016. E-book disponível em: https://saudebusiness.com/author/tymo-nakao/. Acesso: agosto/2018.

OLIVEIRA, Aline Ap. S.; QUEIROZ NETO, Rosário R.; QUEIROZ, Jusceni F.; DUARTE, Silvana. EMPREENDEDORISMO DIGITAL: SUAS CONTRIBUIÇÕES NO ÂMBITO ECONÔMICO E SOCIAL. Rev. Eletrônica Organ. Soc., Iturama (MG), v. 8, n. 9, p. 56-68, jan./jun. 2019 DOI: 10.29031/ros.v8i9.436. Acesso julho/2019.

ORTEGA, Maria C. B.; CECAGNO, Diana; LLOR, Ana M. S.; SIQUEIRA, Hedi C. H.; MONTESINOS, Maria José L.; SOLER, Loreto M. FORMAÇÃO ACADÊMICA DO PROFISSIONAL DE ENFERMAGEM E SUA ADEQUAÇÃO ÀS ATIVIDADES DE TRABALHO. Revista Latino Americana de Enfermagem. maio-jun. 2015. Disponível em: http://www.scielo.br/pdf/rlae/v23n3/pt_0104-1169-rlae-23-03-00404.pdf. Acesso: julho/2019.

PADOVANI, Ornella; CORRÊA, Adriana K. CURRÍCULO E FORMAÇÃO DO ENFERMEIRO: DESAFIOS DAS UNIVERSIDADES NA ATUALIDADE. Revista Saúde \& Transformação Social. Florianópolis, v.8, n.2, p.112-119, 2017. Disponível em: http://incubadora.periodicos.ufsc. br/index.php/saudeetransformacao/article/view/3841/4990. Acesso: agosto/2019.

PATTON, M. Q. QUALITATIVE RESEARCH AND EVALUATION METHODS. Thousand Oaks, CA: Sage Publications, 2002. 
CAGGY, Ricardo C.; PEDROSO, Fábio; BRITO, Francivan. AVALIAÇÃo DO PERFIL EMPREENDEDOR DE ESTUDANTES EM UMA FACULDADE CONFESSIONAL: ESTRATÉGIAS, RESULTADOS E LIMITAÇÕES NA CRIAÇÃO DE UMA CULTURA UNIVERSITÁRIA EMPREENDEDORA. Revista Formadores - Vivências e Estudos, Cachoeira - Bahia, v. 10, n. 6, p. 24 - 44, nov. 2017. Disponível em: http://www.seer-adventista.com.br/ojs/index.php/ formadores/article/view/949/726. Acesso Agosto/2018.

PESSOA, Eliana. CONCEPÇÕES SOBRE EMPREENDEDORISMO NA VISÃO DE ALUNOS E PROFESSORES DE CURSOS DE ADMINISTRAÇÃO DE BRASÍLIA. Dissertação de Mestrado Universidade Católica de Brasília, 2008. Acesso: fevereiro /2019.

PIETROVSKI, Eliane Fernandes; SCHNEIDER, Elton Ivan; REIS, Dálcio Roberto; REIS JUNIOR, Dálcio Roberto. ANÁlISE DO POTENCIAL EMPREENDEDOR EM ALUNOS DO ENSINO SUPERIOR: APLICAÇÃO DA TEORIA À PRÁTICA. Revista INNOVAR, v. 29, n. 71. 2019. Disponível em:<http://www.redalyc.org/articulo.oa?id=81859042003>ISSN 0121-5051. Acesso julho/2019.

POLITIS, Diamanto. The process of entrepreneurial learning: A conceptual framework. ENTREPRENEURSHIP THEORY AND PRACTICE, p. 399-424, July 2005. Disponível em: https://www.researchgate.net/publication/228272963. Acesso junho/2019.

POLITIS, Diamanto; GABRIELSSON, Jonas. EXPLORING THE ROLE OF EXPERIENCE IN THE PROCESS FOR ENTREPRENEURIAL LEARNING. LUND INSTITUTE OF ECONOMIC RESEARCH. Working Paper, $2005 . \quad$ Disponível em: https://www.researchgate.net/publication/5093359. Acesso junho/2019.

PRAIS, Jacqueline L.S.; ROSA, Vanderley F. NUVEM DE PALAVRAS E MAPA CONCEITUAL: ESTRATÉGIAS E RECURSOS TECNOLÓGICOS NA PRÁTICA PEDAGÓGICA. Nuances: estudos sobre Educação, Presidente Prudente -SP, v. 28, n. 1, p. 201-219, 2017. Disponível em DOI: 10.14572/nuances.v28i1.4833. Acesso: junho/2019.

QUEIROZ, Sandra. REFLEXÕES SOBRE EDUCAÇÃO PARA A SAÚDE. Observatório das Políticas de Educação e formação - OPEDU. (2011). Disponível em: http://www.opedu.eu/artigo/reflexoes-sobre-educacao-para-a-saude. Acesso maio/2017. 
R Core Team (2018). R: A LANGUAGE AND ENVIRONMENT FOR STATISTICAL COMPUTING. R Foundation for Statistical Computing, Vienna, Austria. Disponível em: http://www.Rproject.org/. Acesso: julho/2019.

RAMALHO, Evandro S.; SOARES, Michelle B.; FARIA, Evandro R.; GONÇALVES, Márcio A.; ANDRADE, Lília P. ANÁLISE DO PERFIL EMPREENDEDOR DOS DISCENTES DOS CURSOS DE CIÊNCIAS CONTÁBEIS E ADMINISTRAÇÃO NAS INSTITUIÇÕES DE ENSINO SUPERIOR DO MUNICÍPIO DE VIÇOSA, MG. Revista Cesumar Ciências Humanas, v. 21, 2016. Disponível em: http://periodicos.unicesumar.edu.br/index/revcesumar/view/3871. Acesso: julho/2019.

RAMOS, M. P. MÉTODOS QUANTITATIVOS E PESQUISA EM CIÊNCIAS SOCIAIS: LÓGICA E UTILIDADE DO USO DA QUANTIFICAÇÃO NAS EXPLICAÇÕES DOS FENÔMENOS SOCIAIS. Mediações - Revista de Ciências Sociais, v. 18, n. 1, p. 55-65, 2013.

REINA, Fábio Tadeu; SANTOS, Roberto Augusto. EDUCAÇÃO EMPREENDEDORA: PRÁTICAS EDUCATIVAS PARA DINAMIZAR A ASCENSÃO PESSOAL E PROFISSIONAL DOS ALUNOS. 2017 Disponível em: https://periodicos.fclar.unesp.br/tes/article/view/9592. Acesso: julho/2019. RICHARDSON, Roberto J. PESQUISA SOCIAL MÉTODOS E TÉCNICAS. 3ạ. ed. São Paulo: Ed. Atlas. 2011.

ROCHA, Estevão Lima C.; FREITAS, Ana Augusta F. AVALIAÇÃo DO ENSINO DE EMPREENDEDORISMO ENTRE ESTUDANTES UNIVERSITÁRIOS POR MEIO DO PERFIL EMPREENDEDOR. Revista de Administração Contemporânea, v. 18, p. 4, 2014.

RODRIGUES, Marco T. O FENÔMENO DO EMPREENDEDORISMO E AS TEORIAS ORGANIZACIONAIS: IDENTIFICANDO A INTERSEÇÃO TEÓRICA DOS DOMÍNIOS. ENANPAD 2007. Disponível em: http://www.anpad.org.br/admin/pdf/ESO-C1701.pdf. Acesso fevereiro/2019.

ROMA, Vitor de Medina Coeli. O EMPREENDEDOR BRASILEIRO: UM ESTUDO EXPLORATÓRIO SOBRE PERSONALIDADE, INTELIGÊNCIA EMOCIONAL E DESEMPENHO. Dissertação de Mestrado. Rio de Janeiro, 2006. Disponível em: http://s3.amazonaws.com/public-cdn.ibmec.br/portalibmec-content/public/arquivos/df/ dis_2006_14_-_vitor_de_medina_coeli_roma.pdf. Acesso: maio/2019. 
ROCHA, Estevão Lima de Carvalho; BACCHI, Gino Augusto. ENSINO DE EMPREENDEDORISMO NOS CURSOS DE GRADUAÇÃO EM ADMINISTRAÇÃO NA CIDADE DE FORTALEZA: UM ESTUDO COMPARATIVO DOS CONTEÚDOS E INSTRUMENTOS PEDAGÓGICOS. XXXIV ANPAD/RJ (2010). Disponível em: http://www.anpad.org.br/admin/pdf/epq567.pdf. Acesso outubro/2018.

SALIM, Cesar Simões; SILVA, Nelson Caldas. INTRODUÇÃO AO EMPREENDEDORISMO: DESPERTANDO A ATITUDE EMPREENDEDORA. Rio de Janeiro: Elsevier, 2010

SAMPIERI, Roberto H.; COLLADO, Carlos F.; LUCIO, Maria P.B. METODOLOGIA DE PESQUISA. 5.ed. Porto Alegre: Ed. Penso, 2013.

SANTA RITA, Luciana P.; OLIVEIRA, Kátia, R. S. O.; GOMES, Cledson C. C.; COSTA, Cínthia B. S.; NASCIMENTO, Thiago C. PEDAGOGIA EMPREENDEDORA: UM ESTUDO DE CASO DAS PRATICAS METODOLÓGICAS DESENVOLVIDAS NA DISCIPLINA. XXVIII Encontro Nacional de Engenharia de Produção. Rio de Janeiro. 2008. Disponível em http://www.abepro.org.br/biblioteca/enegep2008_tn_stp_078_544_11540.pdf. Acesso outubro/2018.

SANTOS, Carlos A. (org.). EDUCAÇÃO EMPREENDEDORA. Pequenos Negócios, Desafios e Perspectivas. Vol. 4, 2014. Disponível em: www.bibliotecas.sebrae.com.br/ARQUIVOS_ CHRONUS/ bds/bds.nsf. Acesso: junho/2019.

SAY, Jean-Baptiste. TRATADO DE ECONOMIA POLÍTICA. Tradução de Balthazar Barbosa Filho. Coleção Os Economistas, São Paulo: Abril Cultural, 1983.

MINELLO, Ítalo F.; SCHAEFER, Ricardo; EDUCAÇÃO EMPREENDEDORA: PREMISSAS, OBJetIVOS E METOdOLOGIAS. Revista Pensamento Contemporâneo em Administração. 2016. Disponível em: DOI: http://dx.doi.org/10.12712/rpca.v10i3.816. Acesso: julho/2019.

SCHMIDT, Carla M., DREHER, Marialva T. CULTURE OF THE ENTREPRENEUR: COLLECTIVE ENTREPRENEURIAL ACTION AND PROFILE OF THE ENTREPRENEUR. REGE USP-Revista De Gestão, 15, 1-14. 2008. Disponível em: http://www.revistas.usp.br/rege/article/36626 Acesso: fevereiro/2019. 
SCHMIDT, Serje; BOHNENBERGER, Maria Cristina. PERFIL EMPREENDEDOR E DESEMPENHO ORGANIZACIONAL. Revista de Administração Contemporânea, v. 13, n. 3, p. 450-467, 2009. Disponível em: http://www.scielo.br/pdf/rac/v13n3. Acesso maio/2019

SCHUMPETER, Joseph A. CAPITALISMO, SOCIALISMO E DEMOCRACIA. Rio de Janeiro: Fundo de Cultura, 1961. Disponível em: http://www.ie.ufrj.br/intranet/ie/userintranet/ hpp/arquivos/100820171042_SchumpeterCapital ismoSocialismoeDemocracia.pdf. Acesso em novembro/2018.

SCHUMPETER, Joseph A. A TEORIA DO DESENVOLVIMENTO ECONÔMICO. São Paulo. Nova Cultura. 1997.

SEBRAE - GEM (2015) GLOBAL ENTREPRENEURSHIP MONITOR - Estudo anual sobre empreendedorismo no Brasil e no Mundo. Disponível em: http://observatorio.sebraema.com.br/media/2014/12/Apresenta\%C3\%A7\%C3\%A3o-GEM2017 - acesso: abril/2017.

SILVA, Fernanda Góes. ENSINO DO EMPREENDEDORISMO NA EDUCAÇÃO BÁSICA: A FORMAÇÃO DO CIDADÃO EMPREENDEDOR EM QUESTÃO. Dissertação de Mestrado. Univas Universidade - Pouso Alegre-MG. 2015. Disponível em: http://www.univas.edu.br/me/docs/dissertacoes2/43.pdf. Acesso junho/2019.

SILVA, Júlio F. S.; PENA, Roberto P. M. O “BÊ-Á-BÁ” DO ENSINO EM EMPREENDEDORISMO: UMA REVISÃO DA LITERATURA SOBRE OS MÉTODOS E PRÁTICAS DA EDUCAÇÃO EMPREENDEDORA. Revista de Empreendedorismo e Gestão de Pequenas Empresas | v.6 | n.2 | p. 372-401 | Mai/Ago. 2017. Disponível em: https://www.regepe.org.br/regepe/article /view/563/pdf. Acesso: julho/2019.

SOUZA, Ana C. C.; FILHA Maria José M. M.; SILVA, Lúcia F.; MONTEIRO, Ana R. M.; FIALHO, Ana V. M. FORMAÇÃO DO ENFERMEIRO PARA O CUIDADO: REFLEXÕES DA PRÁTICA PROFISSIONAL. Revista Brasileira de Enfermagem - vol.59 no.6 Brasília Nov./Dec. 2006. Disponível em: http://www.scielo.br/scielo.php?script=sci_arttext\&pid=S003471672006000600016. Acesso: agosto/2019. 
SOUZA, Ângela M.; SARAIVA, Luiz A. S. PRÁtICAS E DESAFIOS DO ENSINO DE EMPREENDEDORISMO NA GRADUAÇÃO EM UMA INSTITUIÇÃO DE ENSINO SUPERIOR. Revista Gestão \& Regionalidade - Vol. 26 - № 78 - set-dez/2010. Disponível em: http://seer.uscs.edu.br/index.php/revista_gestao/article/892/843. Acesso maio/2017.

SOUZA, Eda C. L., GUIMARÃES, Tomás de A. (Org.). EMPREENDEDORISMO ALÉM DO PLANO DE NEGócio. 1. ed. São Paulo: Atlas, 2006.

SOUZA, Eda C. L., SOUZA, Cristina C. L., ASSIS, Simone A. G., ZERBINI, Thais (2004). MÉTODOS E TÉCNICAS DE ENSINO E RECURSOS DIDÁTICOS PARA O ENSINO DO EMPREENDEDORISMO EM IES BRASILEIRAS. ANPAD. Disponível em: http://www.anpad.org.br/ admin/pdf/enanpad2004-epa-trabalhoconvidado.pdf - acesso abril/2017

SOUZA, Helcimara A. CULTURA EMPREENDEDORA. Rio de Janeiro: Editora SESES, 2015. ISBN: 978-85-5548-130-7, 2015.

SOUZA, Helcimara A. A GESTÃO DO CONHECIMENTO NA PEQUENA EMPRESA: Modelagem Organizacional como ferramenta para gerir o conhecimento e o capital intelectual na pequena empresa. 2007. Dissertação de Mestrado - EESC- Universidade de São Paulo - São Carlos-SP. Disponível em: teses.usp.br

STASINOPOULOS D. M. Rigby R.A. (2007) GENERALIZED ADDITIVE MODELS FOR LOCATION SCALE AND SHAPE (GAMLSS) in R. Journal of Statistical Software, Vol. 23, Issue 7, Dec 2007, http://www.jstatsoft.org/v23/i07. Acesso julho/2019.

STASINOPOULOS D. M. Rigby R.A. and Akantziliotou C. (2008) INSTRUCTIONS ON HOW TO USE THE GAMLSS PACKAGE in R Second Edition. CRAN. Acesso julho/2019.

STOCKMANNS, Jussara I. PEDAgOgIA EMPREENDEDORA. Unicentro - Paraná. 2014. Disponível em: http://repositorio.unicentro.br:8080/jspui/Pedagogia-empreendedora.pdf. Acesso: Maio/2019.

TAVARES, Claudia M. (2003). INTEGRAÇÃO CURRICULAR NO CURSO DE GRADUAÇÃO EM ENFERMAGEM. Revista Brasileira Enfermagem, Brasília (DF) 2003 jul/ago;56(4):401-404. Acesso abril/2017 
TERRIM, Sara; MELO, Adler A.R.; JÁCOMO, Alfredo L. EMPREENDEDORISMO EM SAÚDE: RELATO DE MODELO DE EMPRESA JÚNIOR EM MEDICINA. Ver. Med São Paulo 2015 94-8. Disponível: http://dx.doi.org/10.11606/issn.1679-9836.v.94i2p94-98. Acesso: março/2019.

TORO, Lyria Esperanza Perilla, DAVID C. MCCLELLAND (1917 -1998). Revista Latinoamericana de Psicología [en linea] 1998. Universidad Narianal de Colombia. Disponível em: http://www.redalyc.org/articulo.oa?id= 80530309. Acesso janeiro/2019.

TORRES, Rui Sérgio. (2018). ESTUDO DE IMPACTO DO PROGRAMA DE TREINAMENTO COMPORTAMENTAL EM EMPREENDEDORISMO. Dissertação de mestrado. São Paulo/SP. Disponível em: https://www.teses.usp.br/teses/disponiveis/12/12142/tde-27072018111601/publico/CorrigidoRui.pdf. Acesso Abril/2019.

TRIVIÑOS, A. N. S. INTRODUÇÃO À PESQUISA EM CIÊNCIAS SOCIAIS: a pesquisa qualitativa em educação. 1a ed. São Paulo: Atlas, 1987.

USP - UNIVERSIDADE DE SÃO PAULO - PORTAL DE CURSOS: Classificação dos cursos oferecidos pela USP, com base nas áreas de conhecimento. Disponível em: Portal da USP http://www5.usp.br/ensino/graduacao/cursos-oferecidos/areas. Acessos: fevereiro/2017 e janeiro/2019.

VERGA, Everton; SILVA, Luiz F. S. EMPREENDEDORISMO: EVOLUÇÃO HISTÓRICA, DEFINIÇÕES E ABORDAGENS. Revista de Empreendedorismo e Gestão de Pequenas Empresas, v. 3, n. 3, p. 3-30, 2014. Disponível em: https://www.regepe.org.br/regepe/article/view/161/pdf. Acesso em fevereiro/2019.

VERGARA, S. C. MÉTODOS DE PESQUISA EM ADMINISTRAÇÃo. 6. ed. São Paulo, Atlas, 2015. VIEIRA, Kelmara M.; DALMORO, Marlon. Dilemas na Construção de Escalas Tipo Likert: o Número de Itens e a Disposição Influenciam nos Resultados? XXXII Encontro AnPAD - Rio de Janeiro 2008. Disponível em: http://www.anpad.org.br/admin/pdf/EPQ-A1615.pdf. Acesso: junho/2018

VIEIRA, Saulo Fabiano Amâncio; MELATTI, Gerson Antônio; RIBEIRO, Paula Regina. O ENSINO DE EMPREENDEDORISMO NOS CURSOS DE GRADUAÇÃO EM ADMINISTRAÇÃO: UM ESTUDO COMPARATIVO ENTRE AS UNIVERSIDADES ESTADUAIS DE LONDRINA E MARINGÁ. 
Revista de Administração da UFSM (2011), vol. 4, núm. 2, maio-agosto, (2011), pp. 288-301. Disponível em: http://www.redalyc.org/articulo.oa?id=273419420007. Acesso maio/2017.

WEBER, M. A ÉtICA PROTESTANTE E O ESPÍRITO do CAPITALISMO. São Paulo: Companhia das Letras, 2004.

YIN, R. K. ESTUDO DE CASO: planejamento e métodos. 5a ed. Bookman: 2015.

ZAPPELLINI, Marcelo B.; FEUERSCHÜTTE, Simone G. O USO DA TRIANGULAÇÃO NA PESQUISA CIENTÍFICA BRASILEIRA EM ADMINISTRAÇÃO. Revista Ensino e Pesquisa em Administração: Rio de Janeiro, v. 16 No 2 P. 241-273, 2015. Disponível em: https://raep.emnuvens.com.br/raep/article/view/238/183. Acesso: junho/2019.

ZEN, Aurora C.; FRACASSO, Edi Madalena. QUEM É O EMPREENDEDOR? AS IMPLICAÇÕES DE TRÊS REVOLUÇÕES TECNOLÓGICAS NA CONSTRUÇÃO DO TERMO EMPREENDEDOR. Revista de Administração Mackenzie, v. 9, n. 8, art. 197, p. 135-150, 2008. Disponível em: http://www.spell.org.br/documentos/ver/4141. Acesso maio/2019.

ZUCATTO, Luis C. SILVA, Tania N. EMPREENDEDORISMO E COOPERATIVISMO DE ELETRIFICAÇÃO RURAL: O CASO CRELUZ / RS. 2014. XVII Congresso SEMEAD. Disponível em: http://sistema.semead.com.br/17semead/resultado/1354.pdf. Acesso maio/2018. 


\section{APÊNDICE 1 - TCLE - Termo de Consentimento Livre Esclarecido}

\section{Termo de Consentimento Livre e Esclarecido (TCLE)}

Eu, Helcimara Affonso de Souza, pesquisadora e aluna de doutorado do Departamento de Psiquiatria e Ciências Humanas da Escola de Enfermagem de Ribeirão Preto - EERP/USP, estou desenvolvendo a pesquisa intitulada: Empreendedorismo na saúde: Análise da Capacidade Empreendedora dos alunos dos cursos de Enfermagem de uma instituição pública de ensino superior do interior do Estado de São Paulo, que tem como objetivo analisar as características que consiste o perfil empreendedor. A referida pesquisa tem como participantes, os alunos ingressantes e concluintes dos cursos de Bacharelado em Enfermagem, com 130 vagas entre bacharel e licenciatura em Enfermagem, devidamente matriculados no 10 semestre de 2019. Como critério de exclusão, os participantes desta pesquisa deverão possuir a maioridade legal.

A pesquisa foi prevista para ser aplicada em disciplinas oferecidas no semestre onde os alunos estiverem presentes.

Assim, por meio deste Termo de Consentimento Livre e Esclarecido, contendo 02 (duas) páginas devidamente numeradas, gostaria de convidá-lo(a) a participar desta pesquisa, como aluno dos referidos cursos e atendendo o critério de exclusão (maiores de idade), respondendo a um questionário contendo 66 questões, sendo 10 (dez) de caráter sócio-demográfico e 56 (cinquenta e seis) questões que tratam das características do perfil empreendedor. $O$ tempo estimado de sua participação será em torno de 6 a 12 minutos.

Ressalto que sua participação é muito importante para compreendermos as questões relacionadas ao perfil do empreendedor que trata a literatura. Vale dizer também que esta pesquisa não lhe trará nenhum custo, nem tampouco qualquer prejuízo financeiro, sendo sua participação totalmente voluntária, podendo, a qualquer tempo, recusar ou desistir de participar da pesquisa, sem qualquer prejuízo. Como benefícios diretos ou indiretos, no âmbito acadêmico, você poderá obter os resultados desta pesquisa, seja por meio das publicações científicas, ou em contato direto com a pesquisadora, a qualquer tempo, por meio dos mecanismos de contato disponíveis ao final deste termo.

Como risco em participar da pesquisa, pode-se citar eventuais situações de desconforto, inquietude ou cansaço no preenchimento do questionário, no entanto, como forma de manejo, imediatos ou posteriores, me coloco à sua disposição, seja por telefone ou e-mail, para auxiliá-lo no que for necessário. Também me disponibilizo a atendê-lo de forma presencial. Tal atendimento poderá ocorrer durante ou após a presente pesquisa.

Caso ocorram danos decorrentes de sua participação na pesquisa, você terá direito a indenização conforme as leis vigentes no país. 
Caso aceite, você receberá uma via desse termo de consentimento livre e esclarecido, elaborado em 2 (duas) vias de idêntico teor, numeradas, devidamente assinado e datado. Comprometo-me a garantir o sigilo da identidade dos participantes desta pesquisa e atender a todo rigor ético, durante a execução desta pesquisa, bem como quando da publicação dos seus resultados.

Este estudo foi aprovado pelo Comitê de Ética em Pesquisa da Escola de Enfermagem de Ribeirão Preto (CEP-EERP/USP), sob o número 3.293.390. O Comitê de Ética em Pesquisa (CEP) tem a função de proteger eticamente os participantes de pesquisas com seres humanos.

Para informações adicionais, você poderá entrar em contato com o referido Comitê de Ética, situado na Escola de Enfermagem de Ribeirão Preto, Campus Universitário, Av. Bandeirantes, $n^{\circ}$ 3900, Ribeirão Preto, ou via e-mail cep@eerp.usp.br, ou ainda por meio do telefone (16) 3315 9197, nos horários de atendimento: de segunda a sexta-feira, em dias úteis, das 10 às $12 \mathrm{~h}$ e das 14 às $16 \mathrm{~h}$.

Reiterando, que você poderá entrar em contato com a pesquisadora a qualquer momento, durante ou após a pesquisa, por meio de e-mail ou telefone de contato disponíveis neste termo, bem como de forma presencial, para obter informações sobre este estudo, e/ou tomar conhecimento dos resultados obtidos na pesquisa. Por fim, agradeço por sua colaboração e coloco-me inteiramente à sua disposição, para qualquer informação que considerar necessária.

Data: / I

Helcimara Affonso de Souza Telefone: (16) 99162-9088 - e-mail: helcimara.souza@usp.br

( ) Declaro que li e concordo em participar desta pesquisa. 


\section{APÊNDICE 2 - Questionário para Analisar o Perfil Empreendedor}

Caro(a) aluno(a),

Primeiramente agradeço por fazer parte desta pesquisa, que tem como objetivo, analisar o perfil empreendedor dos alunos, desde que maiores de idade, do primeiro e do último ano dos cursos de Enfermagem, bacharelado e licenciatura/bacharelado, da Escola de Enfermagem de Ribeirão Preto EERP/USP. A coleta de dados será realizada por mim, a pesquisadora, e faz parte da pesquisa de campo, da minha tese de doutorado, sob a orientação da Profa Dra Carla Aparecida A. Ventura, vinculadas ao Depto. de Enfermagem Psiquiátrica e Ciências Humanas. As respostas são sigilosas e serão utilizadas apenas com fins acadêmicos. Será aplicado um questionário com 66 questões, sendo 10 (dez) de caráter sócio-demográfico e 56 questões específicas: 55 (cinquenta e cinco) perguntas fechadas e 01 (uma) pergunta aberta, contendo características que descrevem o que a literatura chama de perfil empreendedor. Tal questionário inicia-se com questões de ordem social (como idade, estado civil, etc.) para compreender o perfil de aluno, sem se ater a nenhuma identificação pessoal. Queremos ressaltar que, não existe resposta certa. Assim, pedimos que responda com o máximo de sinceridade possível, para que a análise resulte em dados que tragam o mais alto grau de confiabilidade possível. Você disporá de apenas alguns minutos para responder, cerca de 6 a 12 min. Leia com bastante atenção. Responda as questões de 11 a 65 com base na escala Likert (de 1 a 5), apresentada junto às questões. Já a questão de número 66 é aberta/discursiva, a qual pedimos que responda com objetividade.

Contamos com a sua colaboração e reiteramos os nossos agradecimentos.

Helcimara Affonso de Souza

Doutoranda - EERP-USP

Celular: (16) 99162-9088

\section{PARTE I - PERFIL DO RESPONDENTE}

1. Sexo

$\square$ Feminino

2. Idade:

3. Estado Civil

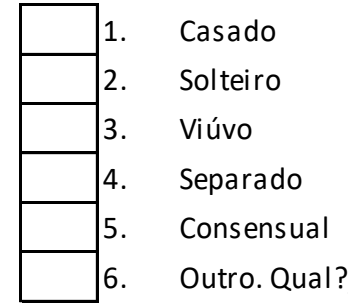

4. Filhos

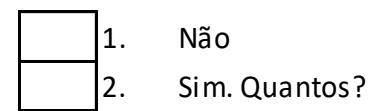

5. Cor / Raça

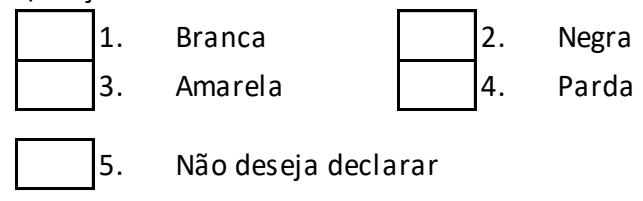

Masculino

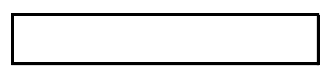

6. Você mora em qual cidade/estado (UF) ?

7. Cursando qual ano do curso de enfermagem?

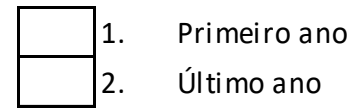

8. Possui algum empreendedor na família?

$$
\begin{array}{|l|ll}
\hline & \text { 1. } & \text { Pai ou Mãe } \\
\hline & \text { 2. } & \text { Tios } \\
\text { 3. } & \text { Primos } \\
\hline & \text { 4. } & \text { Irmãos } \\
\hline & 5 . & \text { Nenhum parente empreendedor. }
\end{array}
$$

9. Já pensou algum dia ter seu próprio negócio?

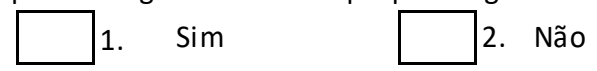

10. Você se considera conhecedor do mercado de trabalho ao qual estará inserido futuramente?

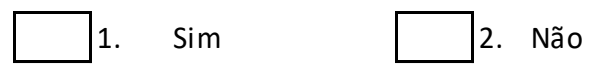




\section{Atenção!!}

Nas afirmações a seguir, não há melhor ou pior resposta; o que importa é a resposta verdadeira, ou seja, uma opinião franca e sincera. Marque com um $\mathrm{X}$ nas colunas a direita de cada questão, considerando a escala dos pontos ao lado, que simbolizam a sequência de 1, 2, 3, 4 e 5, em forma de escala, sendo: 1 discordo totalmente até 5 concordo totalmente.

\begin{tabular}{|c|c|c|c|c|}
\hline 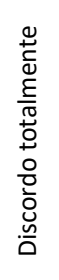 & 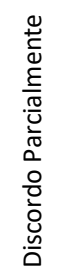 & 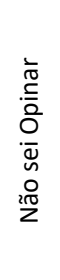 & 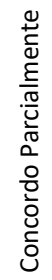 & 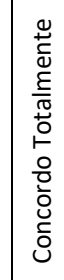 \\
\hline 1 & 2 & 3 & 4 & 5 \\
\hline
\end{tabular}

11. Esforço-me para realizar as coisas que devem ser feitas.

12. Quando me deparo com um problema difícil, levo muito tempo para encontrar a solução.

13. Termino meu trabalho / atividade a tempo.

14. Aborreço-me quando as coisas não são feitas devidamente.

15. Prefiro situações em que posso controlar ao máximo o resultado final.

16. Gosto de pensar no futuro.

17. Quando começo uma tarefa ou projeto novo, coleto todas as informações possíveis antes de dar andamento.

18. Planejo um projeto grande dividindo-o em tarefas mais simples.

19. Consigo que os outros me apoiem em minhas recomendações.

20. Tenho confiança que posso estar bem sucedido em qualquer atividade que me proponha executar.

21. Não importa com quem fale, sempre escuto atentamente.

22. Faço as coisas que devem ser feitas sem que os outros tenham que me pedir.

23. Insisto várias vezes para conseguir que as outras pessoas façam o que desejo.

24. Sou fiel às promessas que faço.

25. Meu rendimento no trabalho / atividades é melhor do que o das outras pessoas com quem trabalho.

26. Envolvo-me com algo novo só depois de ter feito o possível para ter seu êxito.

27. Acho uma perda de tempo me preocupar com o que farei daminha vida.

28. Procuro conselhos das pessoas que são especialistas no ramo em que estou atuando.

29. Considero cuidadosamente as vantagens e desvantagens de diferentes alternativas antes de realizar uma tarefa.

30. Não perco muito tempo pensando em como posso influenciar as outras pessoas.

31. Mudo a maneira de pensar se os outros discordam energicamente dos meus pontos de vista.

32. Aborreço-me quando não consigo o que quero.

33. Gosto de desafios e novas oportunidades.

34. Quando algo se interpõe entre o que eu estou tentando fazer, persisto em minha tarefa.

35. Se necessário não me importo de fazer o trabalho dos outros para cumprir um prazo de entrega.

36. Aborreço-me quando perco tempo.

37. Considero minhas possibilidades de êxito ou fracasso antes de começar atuar.

38. Quanto mais especificas forem minhas expectativas em relação ao que quero obter na vida, maiores serão minhas possibilidades de êxito.

39. Tomo decisões sem perder tempo buscando informações. 


\begin{tabular}{|c|c|c|c|c|c|}
\hline \multirow{2}{*}{$\begin{array}{l}\text { (continuação) } \\
\text { 40. Trato de levar em conta todos os problemas que podem se apresentar e } \\
\text { antecipo o que eu faria caso sucedam. }\end{array}$} & 1 & 2 & 3 & 4 & 5 \\
\hline & & & & & \\
\hline 41. Conto com pessoas influentes para alcançar minhas metas. & & & & & \\
\hline $\begin{array}{l}\text { 42. Quando estou executando algo difícil e desafiador, tenho confiança em seu } \\
\text { sucesso. }\end{array}$ & & & & & \\
\hline 43. Tive fracassos no passado. & & & & & \\
\hline 44. Prefixo executar tarefas que domino perfeitamente e em que me sinto seguro & & & & & \\
\hline $\begin{array}{l}\text { 45. Quando me deparo com sérias dificuldades, rapidamente passo para outras } \\
\text { atividades. }\end{array}$ & & & & & \\
\hline $\begin{array}{l}\text { 46. Quando estou fazendo um trabalho para outra pessoa, me esforço de forma } \\
\text { especial para que fique satisfeita com o trabalho. }\end{array}$ & & & & & \\
\hline $\begin{array}{l}\text { 47. Nunca fico realmente satisfeito com a forma como são deitas as coisas; sempre } \\
\text { considero que há uma maneira melhor de fazê-las. }\end{array}$ & & & & & \\
\hline 48. Executo tarefas arriscadas. & & & & & \\
\hline 49. Conto com um plano claro de vida. & & & & & \\
\hline $\begin{array}{l}\text { 50. Quando executo um projeto para alguém, faço muitas perguntas para } \\
\text { assegurar-me de que entendi o que quer. }\end{array}$ & & & & & \\
\hline $\begin{array}{l}\text { 51. Enfrento os problemas na medida em que surgem, em vez de perder tempo, } \\
\text { antecipando-os. }\end{array}$ & & & & & \\
\hline $\begin{array}{l}\text { 52. Para alcançar minhas metas, procuro soluções que beneficiem todas as pessoas } \\
\text { envolvidas em um problema. }\end{array}$ & & & & & \\
\hline 53. O trabalho que realizo é excelente. & & & & & \\
\hline 54. Em algumas ocasiões obtive vantagens de outras pessoas. & & & & & \\
\hline 55. Aventuro-me a fazer coisas novas e diferentes das que fiz no passado. & & & & & \\
\hline $\begin{array}{l}\text { 56. Tenho diferentes maneiras de superar obstáculos que se apresentam para a } \\
\text { obtenção de minhas metas. }\end{array}$ & & & & & \\
\hline $\begin{array}{l}\text { 57. Minha família e vida pessoal são mais importantes para mim do que as datas de } \\
\text { entregas de trabalho determinadas por mim mesmo. }\end{array}$ & & & & & \\
\hline $\begin{array}{l}\text { 58. Encontro a maneira mais rápida de terminar os trabalhos, tanto em casa quanto } \\
\text { no trabalho / faculdade. }\end{array}$ & & & & & \\
\hline 59. Faço coisas que as outras pessoas consideram arriscadas. & & & & & \\
\hline $\begin{array}{l}\text { 60. Preocupo-me tanto em alcançar minhas metas semanais quanto minhas metas } \\
\text { anuais. }\end{array}$ & & & & & \\
\hline $\begin{array}{l}\text { 61. Conto com várias fontes de informação ao procurar ajuda para a execução de } \\
\text { tarefas e projetos. }\end{array}$ & & & & & \\
\hline $\begin{array}{l}\text { 62. Se determinado método para enfrentar um problema não der certo, recorro a } \\
\text { outro. }\end{array}$ & & & & & \\
\hline $\begin{array}{l}\text { 63. Posso conseguir que pessoas com firmes conviç̧ões e opiniões mudem seu } \\
\text { modo de pensar. }\end{array}$ & & & & & \\
\hline $\begin{array}{l}\text { 64. Mantenho-me firme em minhas decisões, mesmo quando as outras pessoas se } \\
\text { opõem energicamente. }\end{array}$ & & & & & \\
\hline 65. Quando desconheço algo, não hesito em admiti-lo. & & & & & \\
\hline
\end{tabular}

\section{O que você entende pelo termo Empreendedorismo?}




\section{APÊNDICE 3 - Respostas da Pesquisa Qualitativa}

\begin{tabular}{|c|c|}
\hline \multicolumn{2}{|r|}{ DADOS PESQUISA QUALITATIVA - RESPOSTAS ABERTAS DO INSTRUMENTO } \\
\hline ANO & RESPOSTA \\
\hline Ingressantes & PESSOAS QUE QUEREM ABRIR EMPRESA OU JÁ POSSUEM \\
\hline Ingressantes & É DAR INICIA AO SEU PRÓPRIO NEGOCIO \\
\hline Ingressantes & $\begin{array}{l}\text { É UMA INICIATIVA, NORMALMENTE RELACIONADA COM A AREA EMPRESARIAL, PARA A } \\
\text { IMPLEMENTAÇÃO DE NOVAS IDEIAS OU MUDANÇAS NOS NEGÓCIOS }\end{array}$ \\
\hline Ingressantes & EMPREENDER É FAZER ALGO A MINHA MANEIRA QUE RETORNE BOAS COISAS PARA MIM \\
\hline Ingressantes & ENTENDO COMO IDEIA DE CRIAR PROPRIO NEGOCIO \\
\hline Ingressantes & VOCE LUTAR POR ALGO QUE ACREDITA A FIM DE CONSEGUIR REALIZAR SEU PROJETO \\
\hline Ingressantes & CRIAR METAS PARA CONSTRUIR UM NEGOCIO E LUTAR PARA O SUCESSO \\
\hline Ingressantes & É QUANDO A PESSOA INVESTE EM UM PRODUTO PROPRIO \\
\hline Ingressantes & $\begin{array}{l}\text { ABRIR UM COMERCIO, OU ALGO DO TIPO DE MANEIRA A OFERECER PRODUTOS } \\
\text { INOVADORES }\end{array}$ \\
\hline Ingressantes & $\begin{array}{l}\text { COMPREENDE POR COMEÇAR A CONSTRUIR UM NEGOCIO OU FAZER PARTE COMO SOCIO } \\
\text { EM UM JA EXISTENTE }\end{array}$ \\
\hline Ingressantes & SE AUTO-ADMINISTRAR EM CONJUNTO COM UM PROJETO \\
\hline Ingressantes & PARA MIM EMPREENDEDORISMO É UMA FORMA DE ADMINISTRAÇÃO \\
\hline Ingressantes & POSSUIR UMA META, E ATINGIR ESSA META NO FINAL OU ATE MESMO ALEM DELA \\
\hline Ingressantes & ADMINISTRAR, CORRER RISCOS \\
\hline Ingressantes & NÃO ENTENDO MUITO SOBRE O ASSUNTO \\
\hline Ingressantes & SEM RESPOSTA \\
\hline Ingressantes & SEM RESPOSTA \\
\hline Ingressantes & EM BRANCO \\
\hline Ingressantes & SEM RESPOSTA \\
\hline Ingressantes & Prefiro não comentar \\
\hline Ingressantes & EM BRANCO \\
\hline Ingressantes & EM BRANCO \\
\hline Ingressantes & EM BRANCO \\
\hline Ingressantes & $\begin{array}{l}\text { TER RESPONSABILIDADE E REALIZAÇÃO DE TAREFAS QUE AUMENTEM A VIDA PESSOAL NO } \\
\text { SENTIDO DE REALIZAÇÂO NO TRABALHO }\end{array}$ \\
\hline Ingressantes & $\begin{array}{l}\text { CAPACIDADE DE ADMINISTRAR O PROPRIO TEMPO DE FORMA A REALIZAR TAREFAS } \\
\text { PRODUTIVAS }\end{array}$ \\
\hline Ingressantes & $\begin{array}{l}\text { UMA CARACTERISTICA QUE REPRESENTA ALGO COMO ESPIRITO DE LIDERANÇA E } \\
\text { CAPACIDADES DE GERENCIAMENTO DE DINHEIRO, PSSOAS, RELAÇÕES E OPINIÕES, } \\
\text { GERALMENTE VOLTADO PARA O COMERCIO }\end{array}$ \\
\hline Ingressantes & CAPACIDADE DE GERENCIAR, COMANDAR ALGUMA ATIVIDADE \\
\hline Ingressantes & NEGOCIOS - COMPRA E VENDA - LUCRO \\
\hline Ingressantes & É A DISPOSIÇÃO DE REALIZAR E COORDENAR PROJETOS E SERVIÇOS E NEGOCIOS \\
\hline Ingressantes & PLANEJAMENTO, ORGANIZAÇÃO E EXECUÇÃO DE METAS E PROJETOS \\
\hline Ingressantes & $\begin{array}{l}\text { É A CAPACIDADE DE GERIR, PLANEJAR, ADMINISTRAR, COORDENAR E LIDERAR UM } \\
\text { NEGOCIO }\end{array}$ \\
\hline Ingressantes & GERIR A PROPRIA EMPRESA, SER DONO DE SEU PROPRIO NEGOCIO, \\
\hline Ingressantes & CUIDAR DE UM NEGOCIO \\
\hline Ingressantes & $\begin{array}{l}\text { ENTENDO COMO EMPREENDEDORISMO A CAPACIDADE DE COORDENAR TAREFAS, } \\
\text { SERVIÇOS, EMPRESA E SITUAÇÕES }\end{array}$ \\
\hline Ingressantes & $\begin{array}{l}\text { INDIVIDUO COM ESPIRITO DE LIDERANÇA PARA DESENVOLVER PROJETOS, PESQUISAS E } \\
\text { ORGANIZAR UMA EMPRESA }\end{array}$ \\
\hline Ingressantes & $\begin{array}{l}\text { ENTENDO QUE SEJA VC MESMO PRODUZIR ALGO, TER CERTA INDEPENDENCIA EM } \\
\text { RELAÇÃO AQUILO QUE VENDE }\end{array}$ \\
\hline Ingressantes & Idealizar e coordenar projetos e negócios. \\
\hline Ingressantes & Criação de algo novo. \\
\hline Ingressantes & CAPACIDADE DE COORDENAR, ANALIZAR E APLICAR NOVOS PROJETOS \\
\hline Ingressantes & $\begin{array}{l}\text { EMPREENDER É INOVAR, CRIAR POSSIBILIDADES E MANEIRAS DE LIDAR COM DIFERENTES } \\
\text { SITUAÇÕES, DE ACORDO COM O QUE ESCOLHER }\end{array}$ \\
\hline Ingressantes & $\begin{array}{l}\text { ENTENDO COMO UM PROJETO QUE VISA FUNDIR IDEIAS, EMPRESAS, VENDAS, AFIM DE } \\
\text { LEVAR ALGO PARA O SUCESSO }\end{array}$ \\
\hline Ingressantes & MODOS DIFERENTES PARA BUSCAR O SUCESSO EM DETERMINADA SITUAÇÃO \\
\hline
\end{tabular}




\begin{tabular}{|c|c|}
\hline Ingressantes & IDEIAS E PROJETOS PARA BENEFICIO PROPRIO E DOS OUTROS \\
\hline Ingressantes & $\begin{array}{l}\text { É NÂO APENAS TER PLANOS E PROJETOS MAS SABER QUANDO E COMO EXECUTA LOS DE } \\
\text { FORMA SURPREENDENTE E INOVADORA TRANSFORMANDO O CENARIO DA AREA EM QUE } \\
\text { INVESTIRA }\end{array}$ \\
\hline Ingressantes & $\begin{array}{l}\text { ENENDO COMO UM RAMO DE INOVAÇÕES EM QUE O OBJETIVO SE CONSISTE NAS } \\
\text { MUDANÇAS - AVANÇOS PRA A SOCIEDADE }\end{array}$ \\
\hline Ingressantes & INOVAÇÃO ATUALIZAÇÃO E ALTERNATIVAS QUE BUSCAM MELHORAR UM CAMPO \\
\hline Ingressantes & $\begin{array}{l}\text { EMPREENDEDORISMO É CRIAR, INOVAR, EM GERAL, SOLUÇÕES QUE BENEFICIEM AS } \\
\text { PESSOAS DE VARIAS FORMAS GERANDO EMPREGOS, MELHORANDO QUALIDADE DE VIDA } \\
\text { ETC }\end{array}$ \\
\hline Ingressantes & $\begin{array}{l}\text { É INOVAR, RENOVAR O SEU METODO DE TRABALHO, CRIAR NOVAS SOLUÇOES PARA OS } \\
\text { PROBLEMAS QUE O MERCADO ENFRENTA }\end{array}$ \\
\hline Ingressantes & $\begin{array}{l}\text { A CAPACIDADE DE INOVAÇÃO LIGADO AO MERCADO EM QUE UMA OU AIS PESSOAS CRIAM } \\
\text { PROJETOS INOVADORES E OU ABREM O PROPRIO NEGOCIO }\end{array}$ \\
\hline Ingressantes & $\begin{array}{l}\text { EMPREENDER É UMA MANEIRA DE MUDAR E CRIAR NOVAS COLUÇÕES, CONTEÚDOS, } \\
\text { FERRAMENTAS QUE BENEFICIEM DE CERTA FORMA UM GRUPO DE PESSOAS }\end{array}$ \\
\hline Ingressantes & $\begin{array}{l}\text { E EStAR DENTRO DO MERCADO DE TRABALO, EXECUTANDO TAREFAS E BUSCANDO } \\
\text { SOLUÇÕES PARA DETERMINADAS SITUAÇÕES E CRIAR INOVAÇÕES PARA ONDE SE } \\
\text { TRABALHA }\end{array}$ \\
\hline Ingressantes & RENOVAÇÃO \\
\hline Ingressantes & A capacidade de realizar projetos, produzir novas ideias entre outros. \\
\hline Ingressantes & $\begin{array}{l}\text { EMPREENDEDORISMO É A CAPACIDADE DE INOVAR NAS IDEIAS, FAZER ALGO NOVO, } \\
\text { DIFERENTE DOS OUTROS, SE TORNAR EVIDENTE E DE SUCESSO }\end{array}$ \\
\hline Ingressantes & $\begin{array}{l}\text { É CRIAR IDEIAS E PROJETOS QUE DEM CERTO LUCRO PARA UMA EMPRESA, } \\
\text { DESENVOLVENDO ATIVIDADES EM CONJUNTO COM OUTRAS PESSOAS A FIM DE ALCANÇAR } \\
\text { UM OBJETIVO, COMO O LUCRO OU SUCESSO DE ALGO QUE QUEIRA DESENVOLVER }\end{array}$ \\
\hline Ingressantes & $\begin{array}{l}\text { TORNAR UMA IDEIA VALORIZADA, COM APLICABILIDADE NO COTIDIANO E QUE TRAGA } \\
\text { RETORNO A SOCIEDADE }\end{array}$ \\
\hline Ingressantes & $\begin{array}{l}\text { CREIO QUE SE REMETA AO RAMO DE TRABALHO RELACIONADO COM UMA MANEIRA } \\
\text { INOVADORA E MELHOR DE REALIZAR UM DETERMINADO SERVIÇO }\end{array}$ \\
\hline Ingressantes & $\begin{array}{l}\text { EMPREENDER É ENCONTRAR UM PROBLEMA, E ARRANJAR UMA SOLUÇÃO QUE TE FAÇA } \\
\text { GANHAR DINHEIRO }\end{array}$ \\
\hline Ingressantes & OFERECER ALGO AO MERCADO CONSUMIDOR \\
\hline Ingressantes & $\begin{array}{l}\text { Criar, desenvolver e INVESTir em projetos que beneficiem a sociedade e o consumidor e que retorne } \\
\text { lucro para o empreeendedor e sirva como sustento para ele. }\end{array}$ \\
\hline Ingressantes & É INVESTIMENTO. APLICAR CAPITAL EM UMA EMPRESA, EM AÇÕES, EM ALGUMA COISA. \\
\hline Ingressantes & $\begin{array}{l}\text { COMO ALGO QUE ENVOLVE UMA CAPACIDADE DE DESENVOLVER PLANOS, METAS E IDEIAS } \\
\text { PARA ALGO QUE DESEJO INVESTIR, ENVOLVENDO O MEU FUTURO E ALGO QUE QUERO, } \\
\text { PRETENDO DESENVOLVER PARA O CRESCIMENTO PROPRIO E INSERÇÃO DE ALGO NO } \\
\text { MERCADO DE TRABALHO. }\end{array}$ \\
\hline Ingressantes & INVESTIMENTO \\
\hline Ingressantes & $\begin{array}{l}\text { ENTENDO QUE A PARTIR DE UM CONHECIMENTO SOBRE ALGO PODERA DESENVOLVER } \\
\text { HABILIDADES - LIDERANÇA - QUE POSSA AJUDAR EM ALGUM RAMO DE TRABALHO. . UMA } \\
\text { FORMA DE PENSAR DIFERENTE, INVESTINDO NO QUE SABE. }\end{array}$ \\
\hline Ingressantes & $\begin{array}{l}\text { ENTENDO O TERMO EMPREENDEDORISMO O FATO DE TER UMA EMPRESA OU NEGOCIO } \\
\text { PROPRIO, ALGO QUE SEJA CRIADO E DIRIGIDO POR SI PROPRIO }\end{array}$ \\
\hline Ingressantes & $\begin{array}{l}\text { ADMINISTRAR ALGO, NÃO SÓ COMERCIAL, MAS TAMBÉM PESSOAL, COMO O PRÓPRIO } \\
\text { TEMPO, OS GASTOS, NO QUE INVESTIR A ATENÇÃO, OQUE FAZER EM CADA DIA, ETC. }\end{array}$ \\
\hline Ingressantes & CRIAR INVESTIR EM ALGUM SEGMENTO DE MERCADO \\
\hline Ingressantes & VOCE INVESTIR, SE ENTREGAR A ALGUM PLANO, PROJETO NOVO \\
\hline Ingressantes & INVESTIMENTO \\
\hline Ingressantes & $\begin{array}{l}\text { INVESTIR EM IDEIAS OU PROJETOS QUE VÃO GERAR RESULTADOS POSITIVOS } \\
\text { FUTURAMENTE }\end{array}$ \\
\hline Ingressantes & ALGUEM QUE INVESTE EM ALGO, AFIM DE OBTER SUCESSO \\
\hline Ingressantes & QUE É O ATO DE INVESTIR EM ALGO \\
\hline Ingressantes & $\begin{array}{l}\text { ALGUEM QUE SE ARRISCA A FIM DE OBTER SUCESSO FINANCEIRO E PESSOAL EM ALGO } \\
\text { QUE ACREDITA E GOSTA MUITO }\end{array}$ \\
\hline Ingressantes & ENTENDO COMO INVESTIMENTOS \\
\hline Ingressantes & PROCURA DE MEIOS PARA A OBTENÇÃO DE LUCROS \\
\hline Ingressantes & $\begin{array}{l}\text { ENTENDO PELO TERMO EMPREENDEDORISMO UMA ATITUDE QUE ENVOLVE HABILIDADES E } \\
\text { VISÕES FUTURAS DE ALGO QUE POSSA TER RENTABILIDADE }\end{array}$ \\
\hline Ingressantes & $\begin{array}{l}\text { APLICAR RACICINIO, DETERMINAÇÃO E ESFORÇO EM UMA DETERMINADA ATIVIDADE NO } \\
\text { QUAL SE DESEJA OBTER SUCESSO E/OU VANTAGEM FINANCEIRA }\end{array}$ \\
\hline Ingressantes & $\begin{array}{l}\text { APLICAR AÇÕES E NEGOCIOS DE FORMA CONSCIENTES, VISANDO UM RETORNO } \\
\text { FINANCEIRO }\end{array}$ \\
\hline
\end{tabular}




\begin{tabular}{|c|c|}
\hline Ingressantes & $\begin{array}{l}\text { ENTENDO COMO INVESTIMENTO EM UMA ÁREA OU EM VÁRIAS QUE PODEM RESULTAR EM } \\
\text { ALGUMA FORMA DE LUCRO OU PROGRESSO } \\
\text { ACHO QUE EMPREENDEDORISMO EStA LIGADO A CRIAR OBJETIVOS E CUMPRI LOS, É ABRIR } \\
\text { UM NEGOCIO E FAZER DE TUDO PARA QUE ELE DE CERTO, NÃO SE DEIXAR ABALAR PELO } \\
\text { PRIMEIRO NÃO QUE RECEBER. }\end{array}$ \\
\hline Ingressantes & $\begin{array}{l}\text { SAIR DA ZONA DE CONFORTO PARA FAZER ALGO QUE EU DESEJO QUE PODE APRESENTAR } \\
\text { UM CERTO GRAU DE DIFICULDADE. }\end{array}$ \\
\hline Ingressantes & É O ATO DE PLANEJAR ALGO E DEDICAR ATÉ ALCANÇAR \\
\hline Ingressantes & $\begin{array}{l}\text { FORMA DE PLANEJAR E PENSAR NO FUTURO, BUSCANDO SER DETERMINADO E TER UM } \\
\text { OBJETIVO, BUSCANDO TB ENFRENTAR MEDOS E SUPERAR SEMPRE }\end{array}$ \\
\hline Ingressantes & OUTRAS ALTERNATIVAS PARA BUSCAR O SUCESSO EM DETERMINADA SITUAÇÃO \\
\hline Ingressantes & ACHO QUE EMPREENDER É PLANEJAR E FORMULAR UM PLANO QUE ATINJA SEU OBJETIVO \\
\hline Ingressantes & ATO DE PERSISTIR EM UM PROJETO E SE BENEFICIA LO QUANDO HOUVER EXITO \\
\hline Ingressantes & $\begin{array}{l}\text { ENTENDO COMO UM TRABALHO AMPLO, COMMUITAS POSSIBILIDADES DE CRESCIMENTO E } \\
\text { RETORNO, COM LUTA POR ALGUMA META - OBJETIVO }\end{array}$ \\
\hline Ingressantes & $\begin{array}{l}\text { ENTENDO COMO O TALENTO DE INFLUENCIAR AS PESSOAS A ESCOLER OS SEUS } \\
\text { PRODUTOS OU SERVIÇOS ACIMA DE OUTRAS PESSOAS }\end{array}$ \\
\hline Ingressantes & DESEJO DE CRESCER PROFISSIONALMENTE E SONHA DE UMA EMPRESA SUA \\
\hline Ingressantes & $\begin{array}{l}\text { ENTENDO PELO ATO DE FUNDAR E CRIAR UM NEGOCIO PROPRIO PENSANDO } \\
\text { ECONOMICAMENTE, SABENDO ADMINISTRAR, ETC. }\end{array}$ \\
\hline Ingressantes & TER O SEU PROPRIO NEGOCIO OU SER SOCIO DE ALGUM \\
\hline Ingressantes & $\begin{array}{l}\text { ATUAÇÃO NA MONTAGEM, MANUTENÇÃO DE UMA GERAÇÃO EMPREGATICIA DE RENDA E } \\
\text { OCUPACIONAL }\end{array}$ \\
\hline Ingressantes & TER SEU PROPRIO NEGOCIO \\
\hline Ingressantes & É ESTABELECER OBJETIVOS PARA QUE ELES REALIZEM \\
\hline Ingressantes & $\begin{array}{l}\text { ENTENDO COMO A CAPACIDADE QUE UM CERTO INDIVIDUO TEM DE CRIAR SEU PROPRIO } \\
\text { NEGOCIO E TER SUCESSO }\end{array}$ \\
\hline Ingressantes & $\begin{array}{l}\text { UMA FORMA DE PLANEJAR ALGUM OBJETIVO, NEGOCIO PARA O RETORNO DE ALGO } \\
\text { POSITIVO }\end{array}$ \\
\hline Ingressantes & $\begin{array}{l}\text { ENTENDO COMO A PRATICA DE CRIAÇÃO E MANUTENÇAO DE UM NEGOCIO PROPRIO,E QUE } \\
\text { SERÁ ADMINISTRADO PELA PROPRIA PESSOA }\end{array}$ \\
\hline Ingressantes & $\begin{array}{l}\text { É A CAPACIDADE DE IDEALIZAR, COORDENAR E REALIZAR PROJETOS, SERVIÇOS E } \\
\text { NEGOCIOS }\end{array}$ \\
\hline Ingressantes & SER DONO DO PRÓPRIO NEGOCIO \\
\hline Ingressantes & CRIAR UM NEGOCIO PRÓPRIO \\
\hline Ingressantes & $\begin{array}{l}\text { TER SEU PRÓPRIO NEGOCIO/PROJETO/META, PENSANDO NO FUTURO E ESTABELECENDO } \\
\text { METAS DE ACORDO COM O RAMO QUE QUER ATINGIR }\end{array}$ \\
\hline Ingressantes & $\begin{array}{l}\text { E quando vc tem sua empresa ou algo que vc sabe lhe dar tanto com profissionalismo e dentro das } \\
\text { normais das leis }\end{array}$ \\
\hline Ingressantes & $\begin{array}{l}\text { ENTENDO O TERMO EMPREENDEDORISMO O FATO DE TER UMA EMPRESA OU NEGOCIO } \\
\text { PROPRIO, ALGO QUE SEJA CRIADO E DIRIGIDO POR SI PROPRIO }\end{array}$ \\
\hline Ingressantes & ALGUÉM QUE BUSCA TER O SEU PROPRIO NEGOCIO, UMA RENDA ATRAVES DE ALGO SEU \\
\hline Ingressantes & ALGUEM QUE SE ARRISCA PARA CRIAR SEU PROPRIO NEGOCIO \\
\hline Ingressantes & $\begin{array}{l}\text { O ATO DE INICIAR UM NOVO NEGOCIO, DE FORMA INOVADORA E QUE TRAGA BENEFICIOS } \\
\text { PARA TODAS AS PARTES ENVOLVIDAS }\end{array}$ \\
\hline Ingressantes & QUANDO UM MONTA SEU PROPRIO NEGOCIO \\
\hline Ingressantes & SER EMPREENDEDOR DE ALGUMA EMPRESA \\
\hline Ingressantes & É QUANDO A PESSOA POSSUI SEU PROPRIO NEGOCIO \\
\hline Ingressantes & $\begin{array}{l}\text { GESTÃO, AUTONOMIA, TER O PROPRIO NEGOCIO, ADMINISTRAR, LIDERAR } \\
\text { ENTENDO QUE SEJA UMA FORMA QUE ALGUEM CONSIGA SER CRIATIVO E SAIBA } \\
\text { APROVEITAR AS OPORTUNIDADES PARA LUCRAR COM DETERMINADO SERVIÇO, SEU } \\
\text { PROPRIO NEGOCIO }\end{array}$ \\
\hline Ingressantes & UM PROFISSIONAL QUE TEM SEU PROPRIO NEGOCIO E QUE BUSCA INOVAR \\
\hline Ingressantes & $\begin{array}{l}\text { PROFISSIONAIS QUE PENSEM ALÉM DO QUE TODOS OS OUTROS E PERCEBEM QUE AQUILO } \\
\text { TEM POTENCIAL }\end{array}$ \\
\hline Ingressantes & CORRER RISCO E TER LUCRO CM PROPRIO NEGOCIO \\
\hline Ingressantes & O FATO DE IMPLEMENTAR NOVOS NEGOCIOS \\
\hline Ingressantes & $\begin{array}{l}\text { EMPREENDER É CONSTRUIR UM NEGOCIO DO ZERO, COMEÇAR ALGO NOVO, EMPRESA, } \\
\text { COM METAS, PROPÓSITOS, VALORES, PESSOAS COM PENSAMENTO PARECIDO E COM A } \\
\text { VONTADE DE CRESCER JUNTO COM A EMPRESA ETC. }\end{array}$ \\
\hline Ingressantes & AÇÃO DE VITORIA E APRENDIZADO \\
\hline Ingressantes & $\begin{array}{l}\text { ENTENDO COMO UM TERMO USADO PARA DESIGNAR UMA CARACTERÍSTICA DE PESSOAS } \\
\text { QUE ASSUMAM RISCOS, CAPACIDADE DE GERENCIAR, LIDAR COM PESSOAS E NEGÓCIOS } \\
\text { QUASE COMO UM ADJETIVO. }\end{array}$ \\
\hline
\end{tabular}




\begin{tabular}{|c|c|}
\hline Ingressantes & EMPREENDER ALGO QUE VOCÊ POSSUI CONHECIMENTO \\
\hline Ingressantes & EMPREENDEDORISMO É EMPREENDER, CONHECER \\
\hline Ingressantes & $\begin{array}{l}\text { EMPREENDEDORISMO E VOCÊ CRESCER PROFISSIONALMENTE COM ESFORÇO SEM EM } \\
\text { NINGUÉM. }\end{array}$ \\
\hline Ingressantes & ENTENDO QUE É UMA PESSOA DETERMINADA E SEGURA DE SUAS AÇÕES \\
\hline Ingressantes & EM BRANCO \\
\hline Ingressantes & EM BRANCO \\
\hline Ingressantes & EM BRANCO \\
\hline Ingressantes & EM BRANCO \\
\hline Ingressantes & EM BRANCO \\
\hline Ingressantes & EM BRANCO \\
\hline Ingressantes & EM BRANCO \\
\hline Ingressantes & EM BRANCO \\
\hline Ingressantes & EM BRANCO \\
\hline Ingressantes & EM BRANCO \\
\hline Ingressantes & EM BRANCO \\
\hline Ingressantes & EM BRANCO \\
\hline Ingressantes & EM BRANCO \\
\hline Ingressantes & EM BRANCO \\
\hline Ingressantes & EM BRANCO \\
\hline Ingressantes & EM BRANCO \\
\hline Ingressantes & EM BRANCO \\
\hline Ingressantes & NADA \\
\hline Ingressantes & EM BRANCO \\
\hline Ingressantes & EM BRANCO \\
\hline Ingressantes & EM BRANCO \\
\hline Ingressantes & NADA \\
\hline Ingressantes & EM BRANCO \\
\hline Ingressantes & NÃO ENTENDO NADA \\
\hline Ingressantes & NÃO TENHO ENTENDIMENTO DE EMPREENDEDORISMO \\
\hline Ingressantes & EM BRANCO \\
\hline Ingressantes & EM BRANCO \\
\hline Ingressantes & EM BRANCO \\
\hline Ingressantes & EM BRANCO \\
\hline Ingressantes & EM BRANCO \\
\hline Ingressantes & EM BRANCO \\
\hline Ingressantes & NÃO SEI \\
\hline Ingressantes & EU NÃO TENHO NENHU EXPERIENCIA NEM SEI OQUE FALAR SOBRE EMPREENDEDORISMO \\
\hline Ingressantes & NÃO TENHO CONHECIMENTO EM EMPREENDEDORISMO \\
\hline Ingressantes & $\begin{array}{l}\text { ENTENDO QUE É A HABILIDADE DE CONSEGUIR ADMINISTRAR UM NEGOCIO, ALGUÉM COM } \\
\text { CRIATIVIDADE E UM CERTA MANIPULAÇÃO NA HORA DE FALAR PARA CONVENCER } \\
\text { PESSOAS COM CONVICÇÕES FIRMES QUE O SEU NEGOCIO É BOM. }\end{array}$ \\
\hline Ingressantes & $\begin{array}{l}\text { SABER ADMINISTRAR COM GRANDE COMPETÊNCIA, AGILIDADE E INTELIGENCIA, O LOCAL } \\
\text { ONDE ESTOU, SEJA UMA EMPRESA UM NEGOCIO ETC. }\end{array}$ \\
\hline Ingressantes & $\begin{array}{l}\text { E UM CONCEITO DE ADMINISTRAÇÃO DE UMA EMPRESA, INVESTIMENTO, DESCOBERTAS DE } \\
\text { OPORTUNIDADES }\end{array}$ \\
\hline Ingressantes & TER A VISA FINANCEIRA INDEPENDENTE \\
\hline Ingressantes & INICIATIVA DE IMPLEMENTAR NOVOS NEGOCIOS \\
\hline Ingressantes & $\begin{array}{l}\text { O EMPREENDEDORISMO E A CAPACIDADE DE COORDENAR UM NEGOCIO, NÃO SOMENTE } \\
\text { ISSO, TAMBÉM A MANEIRA DE INOVAR, DE DAR A INICIATIVA DE IMPLEMENTAR NOVOS } \\
\text { NEGÓCIOS OU POSSÍVEIS MUDANÇAS }\end{array}$ \\
\hline Ingressantes & $\begin{array}{l}\text { UMA IDEIA PRA LUCRAR, CRIAR ALGO NOVO, PENSAR NO FUTURO, ARRISCARMOS SEM } \\
\text { DEIXAR DE PENSAR NO QUE PODE ACONTECER. }\end{array}$ \\
\hline Ingressantes & A PESSOA SE ARRISCAR COM O NOVO \\
\hline Ingressantes & $\begin{array}{l}\text { É VOCÊ INOVAR, NÃO TER MEDO DE ARRISCAR, É SUPRIR UMA NECESSIDADE DA } \\
\text { SOCIEDADE TRAZER COISAS NOVAS PARA O MERCADO DE TRABALHO }\end{array}$ \\
\hline
\end{tabular}




\begin{tabular}{|c|c|}
\hline Ingressantes & $\begin{array}{l}\text { CRIAR, RECRIAR, INOVAR, FAZER O MELHOR QUE POSSA, ENTRAR DE CABEÇA, } \\
\text { MERGULHAR NOS SONHOS }\end{array}$ \\
\hline Ingressantes & $\begin{array}{l}\text { EMPREENDER BUSCAR COISA NOVAS E AUTÔNOMAS, QUE TRAGAM NOVIDADE TALVEZ AO } \\
\text { MERCADO NÃO ABRINDO MÃO DA SUA ESSENCIALIDADE OU MELHOR PRIORIZANDO O SEU } \\
\text { ESSENCIAL }\end{array}$ \\
\hline Ingressantes & INVESTIMENTOS AGUARDANDO RETORNO \\
\hline Ingressantes & UM INVESTIMENTO A LONGO PRAZO, UM ESFORÇO PARA TER U M RESULTADO NO FUTURO \\
\hline Ingressantes & INVESTIMENTOS \\
\hline Ingressantes & $\begin{array}{l}\text { BOM É BUSCAR UMA MELHORIA PARA O FUTURO EM UM INVESTIMENTO QUE EU PRETENDO } \\
\text { FAZER, QUE POSSA TER UM RETORNO NO FUTURO. }\end{array}$ \\
\hline Ingressantes & AQUELE QUE FAZ INVESTIMENTO \\
\hline Ingressantes & $\begin{array}{l}\text { EMPREENDEDORISMO, ACREDITAR, INVESTIR, GERIR UMA IDEIA E COLOCA LA EM PRATICA, } \\
\text { NO RAMO PROFISSIONAL. }\end{array}$ \\
\hline Ingressantes & SE DEDICAR EM ALGO BOM (SERVIÇO, DINHEIRO \\
\hline Ingressantes & $\begin{array}{l}\text { ME CONSIDERO LEIGO NO ASSUNTO, MAS ACREDITO QUE SEJA INVESTIMENTO COM } \\
\text { CRIATIVIDADE NO MERCADO. }\end{array}$ \\
\hline Ingressantes & INVESTIMENTO DE RISCO COM PROBABILIDADES A GRANDES GANHOS \\
\hline Ingressantes & ENTENDO QUE AJUDA A CONTROLAR OS GASTOS \\
\hline Ingressantes & E VOCÊ INVESTIR NAQUILO QUE VOCÊ ACREDITA QUE VAI DAR CERTO \\
\hline Ingressantes & EM BRANCO \\
\hline Ingressantes & EMPREENDEDORISMO É VOCÊ INVESTIR EM UM PROGRAMA \\
\hline Ingressantes & TORNAR ALGO REMUNERÁVEL POSSÍVEL PARA FINS FUTUROS. \\
\hline Ingressantes & COMO A ÁREA DO MERCADO DE TRABALHO \\
\hline Ingressantes & CONFIANÇA, METAS E OBJETIVOS \\
\hline Ingressantes & SER DONO DE SUA PRÓPRIA VIDA E FUTURO. \\
\hline Ingressantes & $\begin{array}{l}\text { CAPACIDADE DE RALIZAR, COORDEENAR, TER INICIATIVAS, COLOCAR UMA EMPRESA COM } \\
\text { GRANDES DIFICULDADES NO MERCADO NOVAMENTE, COLOCAR PRODUTOS NOVOS NO } \\
\text { MERCADO, SEM MEDO DE INVESTIR }\end{array}$ \\
\hline Ingressantes & $\begin{array}{l}\text { PARA SER EMPREENDEDOR TEM QUE SER DETERMINADO, NÃO TER MEDO, TER ESPIRITO } \\
\text { DE AMBIÇÃO, SER SINCERO E CORRETO E NÃO DESISTIR, SEMPRE BUSCAR O MELHOR } \\
\text { JEITO DE SER FEITO }\end{array}$ \\
\hline Ingressantes & $\begin{array}{l}\text { E VOCÊ INVESTIR EM ALGO, QUE PODE OU NÃO DAR EXITO, E VOCÊ ACREDITA QUE VAI } \\
\text { DAR CERTO }\end{array}$ \\
\hline Ingressantes & UMA PESSOA CAPAZ DA SE DEDICAR E SE EMPENHAR EM DETERMINADA SITUAÇÃO \\
\hline Ingressantes & VOCÊ PERSISTIR EM ALGO ESPECIFICO \\
\hline Ingressantes & $\begin{array}{l}\text { CORAGEM DE ARRISCAR, JOGO DE CINTURA PARA PROBLEMAS, BOA CAPACIDADE PARA } \\
\text { LIDAR COM FRACASSOS E SURPREENDENTE CAPACIDADE DE SE REINVENTAR, ESTUDAR } \\
\text { SEMPRE, ANTENADO TAMBEM }\end{array}$ \\
\hline Ingressantes & $\begin{array}{l}\text { PESSOAS CAPAZES DE ALTO SE SUSTENTAR, DOMINAR, ENTENDER, ADMINISTRAR, OUVIR, } \\
\text { COMPREENDER E DE AJUDAR, UMA PESSOA QUE SABE GANHAR E APRENDER NOS ERROS. }\end{array}$ \\
\hline Ingressantes & $\begin{array}{l}\text { É NÃO TER MEDO DE SE ARRISCAR, CORAGEM PARA ENFRENTAR OS PERCALÇOS QUE } \\
\text { POSSAM SURGIR PELO CAMINHO E SABEDORIA NA BUSCA POR SOLUÇÕES. }\end{array}$ \\
\hline Ingressantes & VOCE TER UM OBJETIVO EM PLANEJAMENTO E SER DETERMINADO A POR EM PRATICA \\
\hline Ingressantes & $\begin{array}{l}\text { É A CAPACIDADE DE REALIZAR PROJETOS, NEGOCIOS, SERVIÇOS OU ATÉ MESMO MUDAR A } \\
\text { EMPRESA }\end{array}$ \\
\hline Ingressantes & $\begin{array}{l}\text { EMPREENDEDORISMO E VOCÊ EXECUTAR UMA TAREFA DENTRO DOS LIMITES E RESPEITO } \\
\text { E ÉTICA SOBRE SEU COLEGA OU GRUPO, REALIZAÇÕES DE TAREFAS EM EQUIPE E } \\
\text { LIDERAR UMA EQUIPE ÕES }\end{array}$ \\
\hline Ingressantes & $\begin{array}{l}\text { ENTENDE QUE É A FORMA DE OBTER SUCESSO FINANCEIRO, FAMILIAR E UM FUTURO } \\
\text { PROMISSOR }\end{array}$ \\
\hline Ingressantes & EMPREENDEDORISMO É QUANDO VOCÊ TEM UM PRÓPRIO NEGOCIO TEM U \\
\hline Ingressantes & QUANDO UMA PESSOA SE DEDICA EM SEU PRÓPRIO NEGOCIO \\
\hline Ingressantes & $\begin{array}{l}\text { QUANDO DEIXAMOS DE TRABALHAR PARA OUTRAS PESSOAS E TRABALHAMOS PARA NOS } \\
\text { MESMOS E PARA REALIZAÇÃO DOS NOSSOS SONHOS }\end{array}$ \\
\hline Ingressantes & $\begin{array}{l}\text { EMPREENDEDORISMO E QUEM TEM SEU PRÓPRIO NEGOCIO OU QUEM INVESTE NO } \\
\text { MERCADO }\end{array}$ \\
\hline Ingressantes & $\begin{array}{l}\text { EMPREENDEDORISMO E O DONO DO SEU PRÓPRIO NEGOCIO OU QUE TRABALHE NESSE } \\
\text { RAMO DE NEGOCIO }\end{array}$ \\
\hline Ingressantes & INVESTIMENTO DE VIDA, VISANDO MELHORAR O CUSTO E LONGO PRAZO \\
\hline Ingressantes & TER SEU PRÓPRIO NEGOCIO, UMA IDEIA PARA LUCRAR MAIS \\
\hline Ingressantes & PESSOAS BEM SUCEDIDAS QUE CONQUISTA SEU PRÓPRIO NEGOCIO \\
\hline Ingressantes & NEGOCIO PRÓPRIO VOCÊ SER DONO DO SEU PRÓPRIO NEGOCIO \\
\hline Ingressantes & UM SONHO DE CONSTRUIR ALGO SEU, TER SUA VIDA FINANCEIRA INDEPENDENTE \\
\hline
\end{tabular}




\begin{tabular}{|c|c|}
\hline Ingressantes & $\begin{array}{l}\text { INVESTIR EM ALGUM PROJETO, SONHO COM OBJETIVO DE REALIZAÇÃO E } \\
\text { CONSEQUENTEMENTE INDEPENDÊNCIA FINANCEIRA }\end{array}$ \\
\hline Ingressantes & EMPREENDEDORISMO E FAZER SEU PRÓPRIO NEGOCIO \\
\hline Ingressantes & $\begin{array}{l}\text { O ATO DE EMPREENDER, TER UM NEGOCIO, INVESTIR EM ALGO QUE SEJA PRÓXIMO OU } \\
\text { ALGO QUE TENHA INVENTADO }\end{array}$ \\
\hline Ingressantes & É AQUELE QUE TOMA A INICIATIVA DE EMPREENDER, DE TER UM PRÓPRIO NEGOCIO. \\
\hline Ingressantes & INICIATIVA DE IMPLEMENTAR NOVOS NEGOCIOS \\
\hline Ingressantes & $\begin{array}{l}\text { SOBRE TEMA EMPREENDEDORISMO, ENTENDO QUE É UMA FORMA DE INICIAR E ARRISCAR } \\
\text { SE EM UM PROJETO, TENDO PLANEJAMENTO E CONTANDO COM CERTO TALENTO } \\
\text { PESSOAL. }\end{array}$ \\
\hline Ingressantes & $\begin{array}{l}\text { QUANDO ALGUÉM QUER TER SEU PRÓPRIO NEGOCIO E COSTUMA PROCURAR MODOS DE } \\
\text { CRESCER }\end{array}$ \\
\hline Ingressantes & $\begin{array}{l}\text { EMPREENDEDORISMO É QUANDO ALGUÉM TEM UM COMERCIO OU ALGO PRÓPRIO PRA } \\
\text { FINS DE LUCROS. }\end{array}$ \\
\hline Ingressantes & ALGUÉM QUE É DONO DE UMA DETERMINADA EMPRESA \\
\hline Ingressantes & É SER DONO DE SEU PRÓPRIO NEGÓCIO \\
\hline Ingressantes & $\begin{array}{l}\text { PESSOA QUE INVESTE SEU TEMPO, SEU FINANCEIRO, SONHO NUM PROJETO PARA MÉDIO } \\
\text { OU LONGO PRAZO }\end{array}$ \\
\hline Ingressantes & DONA DO MEU NEGOCIO, DA MINHA VIDA DE TRABALHO. \\
\hline Ingressantes & $\begin{array}{l}\text { PELO TERMO EMPREENDEDORISMO ENTENDO QUE É ALGO A SE CONSTRUIR PENSANDO } \\
\text { EM ALGO MAIOR NO FUTURO, UM RAMO DE COMERCIO VISANDO O LUCRO E O BEM DE } \\
\text { TODOS }\end{array}$ \\
\hline Ingressantes & ENTENDO QUE É FAZER ALGO PARA TER SEU PROPRIO NEGOCIO \\
\hline Ingressantes & $\begin{array}{l}\text { APLICAR TEMPO RECURSOS E CONHECIMENTOS PARA FAZER ABRIR NEGÓCIOS PARA FINS } \\
\text { LUCRATIVOS }\end{array}$ \\
\hline Ingressantes & É QUANDO A PESSOA TEM SUA PRÓPRIA EMPRESA \\
\hline Ingressantes & SER DONO DO PRÓPRIO NEGOCIO \\
\hline Ingressantes & SER DONO DO PRÓPRIO NEGOCIO \\
\hline Ingressantes & $\begin{array}{l}\text { BUSCAR CONHECIMENTO, JORNADA DE DESAFIOS AJUDA A CONSTRUIR, SEU PRÓPRIO } \\
\text { NEGOCIO }\end{array}$ \\
\hline Ingressantes & PESSOA QUE SÃO DONAS DO SEU PRÓPRIO NEGOCIO \\
\hline Ingressantes & ABRIR SUA PROPRIA EMPRESA \\
\hline Ingressantes & TIRAR ALGO QUE ESTA EM MENTE E COLOCAR EM PRATICA \\
\hline Ingressantes & $\begin{array}{l}\text { EMPREENDER, INVESTIR, POUPAR E LANÇAR FINANCEIRAMENTE, EVOLUIR CRIAR ALGO, } \\
\text { SER PATRÃO DE SI. }\end{array}$ \\
\hline Ingressantes & TEMA RELACIONADO A GERIR SEU NEGOCIO SUA VIDA \\
\hline Ingressantes & $\begin{array}{l}\text { ENTENDO POR EMPREENDEDORISMO, O ATO DE INVESTIR EM UM PRÓPRIO NEGOCIO, } \\
\text { INDEPENDENTE DO RAMO. }\end{array}$ \\
\hline Ingressantes & $\begin{array}{l}\text { EMPREENDEDORISMO É INVESTIR PARA OBTENÇÃO DE LUCRO E CRESCIMENTO DENTRO } \\
\text { DO MERCADO DE TRABALHO }\end{array}$ \\
\hline Ingressantes & $\begin{array}{l}\text { EMPREENDER É INICIAR UM NEGOCIO, ESPECIALMENTE QUE VOCE DOMINE, UM TRABALHO } \\
\text { EXIGE MUITO COMPROMETIMENTO }\end{array}$ \\
\hline Ingressantes & ARRISCAR EM UMA PROPOSTA EM QUE TENHA VISÃO FUTURA \\
\hline Ingressantes & $\begin{array}{l}\text { TER SEU PRÓPRIO NEGOCIO, RESPEITANDO AS PESSOAS TER SEU EMPREENDIMENTO TER } \\
\text { SEU CONHECIMENTO NOS SEUS NEGÓCIOS. }\end{array}$ \\
\hline Ingressantes & EMPREENDEDORISMO É VOCÊ ABRIR SEU PRÓPRIO NEGOCIO \\
\hline Ingressantes & $\begin{array}{l}\text { É A FORMA DE EMPREENDER UM PUBLICO PARA UM FIM (SEJA COMERCIO, TRABALHO OU } \\
\text { CONHECIMENTO) }\end{array}$ \\
\hline Ingressantes & EMPREENDER NEGOCIO, VENDAS, EMPRESAS E MERCADORIAS \\
\hline Ingressantes & IMPLEMENTAR NOVOS NEGÓCIOS COMO EMPRESAS \\
\hline Ingressantes & ALGO DIRECIONADO COMO NOSSO PRÓPRIO NEGOCIO \\
\hline Ingressantes & EMPREENDER ALGO, CRIAR ALGO NO TRABALHO É ABRIR UM COMERCIO POR EXEMPLO \\
\hline Ingressantes & CRIAR NOVAS EMPRESAS \\
\hline Ingressantes & EMPREENDEDORISMO É VOCÊ ABRIR SEU PRÓPRIO NEGOCIO \\
\hline Ingressantes & ALGO VOLTADO PARA ADMINISTRAÇÃO, COMO COMERCIO E AFINS \\
\hline Ingressantes & ADMINISTRAR ALGO E LIDAR COM AS DIFICULDADES SOLUCIONANDOAS \\
\hline Ingressantes & ADMINISTRAR ALGO, GERIR UM NEGOCIO, UMA EMPRESA \\
\hline Ingressantes & QUE SOU EMPREENDEDORA, QUE ESTOU ATUANDO EM UM OBJETO EMPRESARIAL \\
\hline Ingressantes & ENTENDO QUE É UMA MANEIRA DE GOVERNAR UMA EMPRESA \\
\hline Ingressantes & É ADMINISTRAR UMA EMPRESA \\
\hline Ingressantes & ADMINISTRAR ALGO E SABER LIDAR COM AS DIFICULDADES \\
\hline
\end{tabular}




\begin{tabular}{|c|c|}
\hline Ingressantes & $\begin{array}{l}\text { EMPREENDEDORISMO É A CAPACIDADE DO INDIVIDUO UTILIZAR MEIOS ESTRATEGICOS } \\
\text { PARA ATINGIR DETERMINADA META, SEJA RELACIONADA A CARREIRA PROFISSIONAL OU } \\
\text { OBJETIVOS PESSOAIS. }\end{array}$ \\
\hline Ingressantes & $\begin{array}{l}\text { TER SEU PRÓPRIO NEGOCIO DE FORMA VANTAJOSA, OBTENDO LUCROS RADICAIS DEVIDO } \\
\text { AS NOVAS IDEIAS E CRIATIVIDADES. }\end{array}$ \\
\hline Ingressantes & $\begin{array}{l}\text { EMPREENDEDORISMO É QUANDO UM APESSOA TEM A INICIATIVA DE ABRIR UM } \\
\text { NEGOCIOOU MUDAR COISAS JÁ EXISTENTES EM SUA EMPRESA, ELE É CONSIDERADO UM } \\
\text { EMPREENDEDOR }\end{array}$ \\
\hline Ingressantes & EM BRANCO \\
\hline Ingressantes & EM BRANCO \\
\hline Ingressantes & EM BRANCO \\
\hline Ingressantes & EM BRANCO \\
\hline Ingressantes & EM BRANCO \\
\hline Ingressantes & EM BRANCO \\
\hline Ingressantes & EM BRANCO \\
\hline Ingressantes & EM BRANCO \\
\hline Ingressantes & $\begin{array}{l}\text { ENPREENDER, VISAR, PENSAR TANTO NO PRESENTE COMO NO FUTURO, ESTABELECER } \\
\text { METAS E CRESCIMENTO, FAZER DE TUDO PARA ALCANÇA LOS SEMPRE. }\end{array}$ \\
\hline Ingressantes & FAZER ALGO NOVO COLOCAR UM PROJETO EM PRATICA \\
\hline Ingressantes & $\begin{array}{l}\text { ENTENDO QUE QUEM TEM EMPRESA TEM QUE ACHAR METODOS PARA QUE TENHA } \\
\text { CLIENTES FIEIS, E ESTAR SEMPRE RENOVANDO PARA NÃO FICA NA MESMA ROTINA, E } \\
\text { ESTAR SEMPRE CRESCENDO E APARECENDO }\end{array}$ \\
\hline Ingressantes & $\begin{array}{l}\text { SABER APLICAR NOVAS MUDANÇAS EM SEUS NEGOCIOS, SABERCRIAR PRODUTOS E } \\
\text { SEMPRE SABENDO QUE PODE HAVER UM RISCO, TER UMA MENTE INOVADORA. }\end{array}$ \\
\hline Ingressantes & CRIAR ALGO NOVO \\
\hline Ingressantes & É ESTAR SEMPRE RENOVANDO PARA NÃO FICA NA MESMA ROTINA \\
\hline Ingressantes & CRIAR NOVOS PROJETOS, MUDANÇAS EM EMPRESAS. \\
\hline Ingressantes & $\begin{array}{l}\text { UMA PESSOA QUE COMECCA COM POUCO OU NADA UMA EMPRESA, E AOS POUCOS VAI } \\
\text { ADMINISTRANDO E COM ISSO MONTA UMA GRANDE EMPRESA }\end{array}$ \\
\hline Ingressantes & $\begin{array}{l}\text { EMPREENDEDORISMO E ALGO RELACIONADO A ADMINISTRAÇÃO, BUSCANDO A MELHOR } \\
\text { FORMA PARA LIDAR COM AS ADVERSIDADES. }\end{array}$ \\
\hline Ingressantes & $\begin{array}{l}\text { ACREDITO QUE O EMPREENDEDORISMO SEJA PLANEJAR UM FUTURO PARA QUE O } \\
\text { CRESCIMENTO DA SUA EMPRESA SEJA CONSTANTE E BENÉFICO PARA O EMPRESARIO }\end{array}$ \\
\hline Ingressantes & SE ALGUÉM DA MINHA FAMÍLIA TEM ALGUM COMERCIO \\
\hline Ingressantes & EU ENTENDO COMO UMA PESSOA SER DONA DE COMERCIO POR EXEMPLO \\
\hline Ingressantes & EMPREENDEDORISMO É PLANEJAR A SUA PROPRIA EMPRESA \\
\hline Ingressantes & É TER SEU PRÓPRIO NEGOCIO \\
\hline Ingressantes & TER SEU PRÓPRIO NEGOCIO, OBTENDO LUCROS COM IDEIAS E CRIATIVIDADES. \\
\hline Ingressantes & SER DONA DE COMERCIO \\
\hline Concluintes & $\begin{array}{l}\text { começar um novo negócio dedicando seu tempo, energia e INVESTimento em um projeto com a } \\
\text { finalidade de obter um retorno do mesmo }\end{array}$ \\
\hline Concluintes & A vontade, iniciativa de iniciar novos projetos, novos negócios ou empresas \\
\hline Concluintes & $\begin{array}{l}\text { Empreendedorismo é quando voce constroi, monta algo, não necessariamente uma clínica, loja, } \\
\text { empresa }\end{array}$ \\
\hline Concluintes & INVESTir em alguma coisa, começar um negócio de trabalho \\
\hline Concluintes & $\begin{array}{l}\text { CRIAR O PRÓPRIO NEGOCIO, EMPREENDER EM UM SENTIDO EM QUE SE QUEIRA } \\
\text { TRABALHAR }\end{array}$ \\
\hline Concluintes & Uma forma de gerir um serviço autônomo \\
\hline Concluintes & PLANEJAMENTO DE VIDA E DE NEGOCIOS FINANCEIROS \\
\hline Concluintes & SABER TOCAR UMA EMPRESA \\
\hline Concluintes & Uma forma de trabalho que envolve assumir riscos, desenvolver coisas novas e enfrentar desafios \\
\hline Concluintes & Entendo é uma postura, modo de pensar, planejar e executar suas ações para alcançar os objetivos! \\
\hline Concluintes & Buscar desenvolver novas ESTratégias, para alcançar qq que seja seu objetivo. \\
\hline Concluintes & $\begin{array}{l}\text { MOTIVAÇÃO PARA BUSCAR METAS E AÇÕES SEM DESISTIR FACILMENTE TER UMA VISÃO } \\
\text { VOLTADA PARA O FUTURO, PROPONDO SOLUÇÕES PARA CRIAÇÃO DE ALGO NOVO }\end{array}$ \\
\hline Concluintes & $\begin{array}{l}\text { BUSCAR METAS SEM DESISTIR FACIL, VISÃO DO FUTURO, PROPOR SOLUÇÕES PARA ALGO } \\
\text { NOVO }\end{array}$ \\
\hline Concluintes & EM BRANCO \\
\hline Concluintes & SEM RESPOSTA \\
\hline Concluintes & EM BRANCO \\
\hline Concluintes & EM BRANCO \\
\hline
\end{tabular}




\begin{tabular}{|c|c|}
\hline Concluintes & Solução inteligente para resolução de problemas \\
\hline Concluintes & Aquele que tem coragem para encarar novos desafios. \\
\hline Concluintes & $\begin{array}{l}\text { Empreendedorismo, n minha opinião, é um ramo da area dos negocios que trabalha a inovação, a } \\
\text { liderança, a administração. }\end{array}$ \\
\hline Concluintes & Ter uma ideia e coloca la em pratica da melhor forma possivel. \\
\hline Concluintes & Melhorar o modo que algo é feito. \\
\hline Concluintes & $\begin{array}{l}\text { ofertar um produto que sofreu modificações do original, e por ESTe fato, pode ser mais rentável a } \\
\text { pessoa que ESTa vendo ESTe produto. }\end{array}$ \\
\hline Concluintes & Pensar e aplicar novas ideias sobre algo que ja existe de forma a facilitar ou melhorar o mesmo \\
\hline Concluintes & Implementar negócios, mudanças e inovações \\
\hline Concluintes & Eu entendo que é algo que tenha que organizar uma ideia e coloca-la em prática \\
\hline Concluintes & Inovação \\
\hline Concluintes & $\begin{array}{l}\text { é buscar soluções diferentes para a resolução de problemas e fazer disso uma maneira de ganhar } \\
\text { dinheiro }\end{array}$ \\
\hline Concluintes & Ter uma ideia e tomar atitudes para que essa ideia gere frutos para o seu crescimento pofissional \\
\hline Concluintes & $\begin{array}{l}\text { Uma forma de inovação, na qual há um planejamento, plano que pode ESTar relacionado com a } \\
\text { oferta de algum serviço ou produto, ex. envolve vários aspectos, o que inclui liderança, inovação, etc. }\end{array}$ \\
\hline Concluintes & Entendo como algo novo, inovador onde mudanças aconteçam \\
\hline Concluintes & $\begin{array}{l}\text { EMPREENDER É UMA AÇÃO DE BUSCAR NOVOS OBJETIVOS E METAS, NÃO SÓ NO MUNDO } \\
\text { DOS NEGÓCIOS, MAS TAMBÉM NA VIDA, DE FORMA A APOSTAR EM INOVAÇÕES, } \\
\text { DESCOBERTAS, CONSIDERANDO CONHECIMENTOS TEÓRICOS QUE SUBSIDIEM ESSA } \\
\text { PRÁTICA }\end{array}$ \\
\hline Concluintes & INVESTir, negociar \\
\hline Concluintes & $\begin{array}{l}\text { Um termo que ESTá relacionado a liderança, em como podemos influenciar positivamente as outras } \\
\text { pessoas através do conhecimento sobre determinadas áreas. }\end{array}$ \\
\hline Concluintes & $\begin{array}{l}\text { Termo que pode ser empregado para pessoas que possuem a iniciativa de INVESTir tempo, dinheiro } \\
\text { e conhecimento em um negócio/empresa/projeto que gere lucros futuros. }\end{array}$ \\
\hline Concluintes & $\begin{array}{l}\text { Empreendedorismo é o ato de um individuo buscar meios e formas de executar alguma atividade que } \\
\text { traga retorno financeiro }\end{array}$ \\
\hline Concluintes & $\begin{array}{l}\text { FAZER NEGOCIOS. ESTÁ LIGADO AO CAPITALISMO E ASSIM AO EMPREENDER DEVEMOS } \\
\text { VENDER O NOSSO PRODUTO. FONTE DE RENDA }\end{array}$ \\
\hline Concluintes & $\begin{array}{l}\text { EMPREENDEDORISMO É UMA FORMA DE APOSTAR NUM PROJETO COM GARRA E BUSCAR } \\
\text { VARIAS FORMAS PARA QUE ELE SE REALIZE }\end{array}$ \\
\hline Concluintes & Empreendedorismo é a maneira de coordenar serviços, projetos, negócios \\
\hline Concluintes & CAPACIDADE DE REALIZAR PROJETOS OU MELHORAR PROJETOS JÁ EXISTENTES \\
\hline Concluintes & Realizar projetos \\
\hline Concluintes & Negócios, economia, valorização de dinheiro, crescimento pessoal \\
\hline Concluintes & $\begin{array}{l}\text { Empreendedorismo é a promoção de um trabalho realizado com sucesso e compromisso. É arte de } \\
\text { passar diante o fruto do trabalho bem sucedido, seja em qq área. }\end{array}$ \\
\hline Concluintes & Ter seu proprio negocio, liderar. \\
\hline Concluintes & Líder de equipe, ter seu proprio negocio, inovação \\
\hline Concluintes & Empreender negócios \\
\hline Concluintes & Ter seu próprio negócio. \\
\hline Concluintes & ter um negócio próprio, empresa - comércio. Inovação \\
\hline Concluintes & QUANDO SOMOS DONOS OU TEMOS NOSSO PRÓPRIO NEGÓCIO. \\
\hline Concluintes & $\begin{array}{l}\text { É AVISCAR NO PRÓPRIO NEGÓCIO, ESTUDANDO OS PONTOS CHAVES, SER SÓCIO E SABER } \\
\text { A HORA DE INVESTIR }\end{array}$ \\
\hline Concluintes & É ESTAR N O MERCADO DE TRABALHO ATUANDO EM UM NEGÓCIO PRÓPRIO OU NÃO \\
\hline Concluintes & NEGÓCIOS \\
\hline Concluintes & TER UM NEGOCIO PROPRIO \\
\hline Concluintes & $\begin{array}{l}\text { E PODER ABRIR SEU PRÓPRIO NEGOCIO E DESEMVOLVER UM TRABALHO EM EQUIPE E DE } \\
\text { LIDERANÇA }\end{array}$ \\
\hline Concluintes & $\begin{array}{l}\text { ESTÁ LIGADO A MERCADO, A CAPITALISMO, A ABRIR UM NEGOCIO PROPRIO E DELE TIRAR } \\
\text { SUSTENTO }\end{array}$ \\
\hline Concluintes & $\begin{array}{l}\text { A CAPACIDADE QUE ALGUEM TEM DE SE ARRISCAR POR ALGO QUE ELE ACREDITE AO } \\
\text { QUAL REALMENTE TEM CERTEZA DE QUE IRA DAR CERTO }\end{array}$ \\
\hline Concluintes & EM BRANCO \\
\hline Concluintes & EM BRANCO \\
\hline Concluintes & EM BRANCO \\
\hline Concluintes & EM BRANCO \\
\hline
\end{tabular}




\begin{tabular}{|c|c|}
\hline Concluintes & EM BRANCO \\
\hline Concluintes & EM BRANCO \\
\hline Concluintes & EM BRANCO \\
\hline Concluintes & EM BRANCO \\
\hline Concluintes & EM BRANCO \\
\hline Concluintes & SINCERAMENTE NÃO ENTENDO NADA \\
\hline Concluintes & PREFIRO NÃO OPINAR \\
\hline Concluintes & $\begin{array}{l}\text { ENTENDO QUE O EMPREENDEDORISMO SÃO AS VARIAS FORMAS DE VENDER, COMPRAR, } \\
\text { OS PRODUTOS E TAMBÉM UMA MANEIRA DE VIVER }\end{array}$ \\
\hline Concluintes & $\begin{array}{l}\text { CAPACIDADE DE PLANEJAR, ORGANIZAR TAREFAS, OBTER LUCROS, SE EXPONDO OS } \\
\text { RISCOS PARA ALCANÇAR OS OBJETIVOS ASSIM BUSCANDO INFORMAÇÕES }\end{array}$ \\
\hline Concluintes & $\begin{array}{l}\text { CRIAR ALGO QUE VÁ ALEM DAS EXPECTATIVAS, ALGO NOVO, TRILHAR CAMINHOS NOS } \\
\text { QUAIS NÃO FORAM TRILHADOS AINDA }\end{array}$ \\
\hline Concluintes & INOVAÇÃO BUSCA DE MELHORIA AVANÇO \\
\hline Concluintes & BUSCAR NOVAS OPORTUNIDADES \\
\hline Concluintes & $\begin{array}{l}\text { CONSEGUIR TER IDEIAS DE IMPLEMENTAR NOVOS CONCEITOS A SER SEGUIDO POR UM } \\
\text { GRUPO DE PESSOAS }\end{array}$ \\
\hline Concluintes & $\begin{array}{l}\text { CRIAR, INVESTIR, DEDICAR, GERAR OPORTUNIDADES, TER BOAS IDEIAS, METAS, VER } \\
\text { OPORTUNIDADES EM PEQUENAS COISAS. }\end{array}$ \\
\hline Concluintes & $\begin{array}{l}\text { UMA FORMA DE IMPLANTAR NOVAS IDEIAS PARA APRIMORAR E MELHOR UM DETERMINADO } \\
\text { NEGOCIO }\end{array}$ \\
\hline Concluintes & BUSCAR NOVAS OPORTUNIDADES INOVAR \\
\hline Concluintes & EMPREENDEDORISMO É ALGO QUE SE CRESCE A CADA DIA \\
\hline Concluintes & $\begin{array}{l}\text { ENTENDO POR INVESTIMENTOS, TRABALHOS QUE PODEM TER GRANDES RETORNOS, } \\
\text { TANTO FINANCEIRO COMO CONHECIMENTO. }\end{array}$ \\
\hline Concluintes & $\begin{array}{l}\text { QUANDO INVESTIMOS EM ALGO QUE QUEREMOS MUITO, NOSSO SONHOS E METAS POR } \\
\text { EXEMPLO }\end{array}$ \\
\hline Concluintes & $\begin{array}{l}\text { QUANDO UMA PESSOA INVESTE EM SEUS SONHOS PARA ALCANÇAR SEUS OBJETIVOS E } \\
\text { GANHA SEU DINHEIRO COMO MONTANDO UMA EMPRESA POR EXEMPLO, ELAS ARRISCAM } \\
\text { PARA OBTER SUCESSO }\end{array}$ \\
\hline Concluintes & RESOLVER UM PROBLEMA OU UMA SITUAÇÃO, MELHORAR ALGO, INVESTIR EM ALGO \\
\hline Concluintes & $\begin{array}{l}\text { E QUALQUER AÇÃO QUE INVISTA TEMPO E DINHEIRO ESPERANDO UM RETORNO } \\
\text { FINANCEIRO }\end{array}$ \\
\hline Concluintes & $\begin{array}{l}\text { UM INVESTIMENTO FUTURO, ONDE COM MUITA PESQUISA E ESTUDO SEMPRE ESTÁ SENDO } \\
\text { MELHORADO, INVESTINDO CADA VEZ MAIS PARA CRESCER E GERAR LUCRO, TANTO NA } \\
\text { VENDA QUANTO DE VIDA, PESSOA E PERSONALIDADE }\end{array}$ \\
\hline Concluintes & $\begin{array}{l}\text { QUANDO A PESSOA INVESTE EM ALGO QUE ACREDITA QUE PODE DAR CERTO, ALGO QUE } \\
\text { NUNCA NINGUEM, PENSOU OU DE MODO COMO NUNCA PENSOU INOVADOR }\end{array}$ \\
\hline Concluintes & $\begin{array}{l}\text { INVESTIR EM UMA ÁREA QUE GOSTE, TANTO PARA BENEFICIAR OS OUTRO CRESCER } \\
\text { PROFISSIONALMENTE E FINANCEIRAMENTE }\end{array}$ \\
\hline Concluintes & $\begin{array}{l}\text { PENSAR EM UM NOVO MÉTODO DE GANHAR A VIDA MAIS FÁCIL, COM MONOS } \\
\text { DIFICULDADES. }\end{array}$ \\
\hline Concluintes & INVESTIR TEMPO, DINHEIRO E ESFORÇO PARA LUCRAR \\
\hline Concluintes & $\begin{array}{l}\text { E UMA INICIATIVA DE CONSEGUIR CORRER RISCO E REALIZAR NOVOS PROJETOS, E TER } \\
\text { UM OBJETIVO NA VIDA MUITO GRANDE E NÃO TER MEDO DE SE ARRISCAR. }\end{array}$ \\
\hline Concluintes & $\begin{array}{l}\text { GARRA ATITUDE E PERSISTENCIA, PROJETOS NOVOS E INOVADORES, BUSCA DE } \\
\text { CONHECIMENTO PARA AGREGAR EM MEU EMPREENDEDORISMO }\end{array}$ \\
\hline Concluintes & $\begin{array}{l}\text { ACREDITO QUE SEJA RESOLVER SITUAÇÕES COMPLICADAS, OU DESAFIOS QUE A VIDA NOS } \\
\text { IMPÕE }\end{array}$ \\
\hline Concluintes & E A CAPACIDADE DE IDEALIZAR, COORDENAR E REALIZAR PROJETOS \\
\hline Concluintes & $\begin{array}{l}\text { EMPREENDEDORISMO SERIA ALGO EM QUE VOCÊ TENHA CONVICÇÃO DO SUCESSO OU } \\
\text { ALGO QUE FAÇA COMO SATISFAÇÃO PESSOAL PARA BENEFICIO PRÓPRIO OU DE } \\
\text { TERCEIROS }\end{array}$ \\
\hline Concluintes & TER O PRÓPRIO NEGOCIO, SER O DONO DE SI \\
\hline Concluintes & $\begin{array}{l}\text { EMPREENDEDORISMO PARA MIM É EMPREENDER EM ALGO QUE VOCÊ ACREDITE DAR } \\
\text { CERTO, NO MEUM CASO QUERO ME FORMAR E MONTAR UMA EMPRESA DE ASSISTENCIA A } \\
\text { PESSOAS QUE NECESSITAM DE LOCOMOÇÃO MA A REA DA SAÚDE. }\end{array}$ \\
\hline Concluintes & $\begin{array}{l}\text { ALCANÇAR SEU PRÓPRIO NEGOCIO, E NELE DESENVOLVER SEU TRABALHO DA MELHOR } \\
\text { FORMA, EM EQUIPE, REALIZAR UMA LIDERANÇA CORRETA E HONESTA PARA MELHOR } \\
\text { DESENVOLVER SEU TRABALHO E CRESCER PROFISSIONALMENTE }\end{array}$ \\
\hline Concluintes & TER SEU PRÓPRIO NEGOCIO \\
\hline Concluintes & ABRIR SEU PRÓPRIO NEGOCIO \\
\hline Concluintes & $\begin{array}{l}\text { E A CAPACIDADE DE IDEALIZAR E REALIZAR UM PROJETO QUE INICIOU E TEVE EXITO NO } \\
\text { FINAL }\end{array}$ \\
\hline
\end{tabular}




\begin{tabular}{|c|c|}
\hline Concluintes & E A INICIATIVA DE EMPREENDER UM NOVO NEGOCIO \\
\hline Concluintes & $\begin{array}{l}\text { ENTENDO QUE É TER SEU PRÓPRIO NEGOCIO, CONTROLE DO FINANCEIRO E DO } \\
\text { PROFISSIONAL, BUSCANDO SUCESSO. }\end{array}$ \\
\hline Concluintes & FAZER NEGÓCIOS \\
\hline Concluintes & TRABALHAR PARA SI MESMO, EM SUA EMPRESA. \\
\hline Concluintes & EMPREENDER, SER EMPRESARIO TER UM RAMO DE NEGOCIO, EMPREENDER. \\
\hline Concluintes & ABRIR SEU PROPRIO NEGOCIO, INOVAR PRODUTOS E SERVIÇOS \\
\hline Concluintes & $\begin{array}{l}\text { CAPACIDADE DE ESPANDIR OU ABRIR NOVOS NEGÓCIOS, CRESCIMENTO E INVESTIMENTO } \\
\text { PESSOAL PARA VIDA }\end{array}$ \\
\hline Concluintes & $\begin{array}{l}\text { É ALGUÉM QUE ALEM DE TER O PRÓPRIO NEGOCIO É CAPAZ DE CONTROLAR COM EXITO E } \\
\text { TEM CARACTERÍSTICAS PARA SABER LIDAR COM TAL RESPONSABILIDADE }\end{array}$ \\
\hline Concluintes & ABRIR SEU PROPRIO NEGOCIO \\
\hline Concluintes & É ABRIR SEU PROPRIO NEGOCIO \\
\hline Concluintes & ABRIR UMA EMPRESA \\
\hline Concluintes & ADIMINISTRAR UM NEGOCIO NOVO \\
\hline Concluintes & CRIAR UM NEGOCIO \\
\hline Concluintes & ABRIR UM COMERCIO \\
\hline Concluintes & ALGO DIRECIONADO COMO NOSSO PRÓPRIO NEGOCIO \\
\hline Concluintes & $\begin{array}{l}\text { ENTENDO QUE EU SERIA O CENTRO DA DIREÇÃO EM AQUILO QUE ADMINISTRO E } \\
\text { EPROCURO AGRADAR E AJUDAR TODOS A CRESCEREM }\end{array}$ \\
\hline Concluintes & EM BRANCO \\
\hline Concluintes & EM BRANCO \\
\hline Concluintes & EM BRANCO \\
\hline Concluintes & EM BRANCO \\
\hline Concluintes & EM BRANCO \\
\hline Concluintes & EM BRANCO \\
\hline Concluintes & EM BRANCO \\
\hline Concluintes & ENTENDO QUE É UMA MANEIRA DE GOVERNAR UMA EMPRESA \\
\hline Concluintes & Um iniciativa de novos projetos a serem realizados \\
\hline Concluintes & ADMINISTRAR E AJUDAR A CRESCER ECONOMICAMENTE \\
\hline Concluintes & Buscar soluções praticas e novas para situações antigas, persistentes \\
\hline Concluintes & $\begin{array}{l}\text { EU ENTENDO QUE EU SERIA O CENTRO DA DIREÇÃO EM AQUILO QUE EU ADMINISTRO E } \\
\text { EPROCURO AGRADAR E AJUDAR TODOS A CRESCEREM COMO EU. }\end{array}$ \\
\hline
\end{tabular}

